\title{
Fetal asphyxia : a study in preterm lambs
}

Citation for published version (APA):

de Haan, H. H. (1994). Fetal asphyxia : a study in preterm lambs. [Doctoral Thesis, Maastricht University]. Rijksuniversiteit Limburg. https://doi.org/10.26481/dis.19941014hd

Document status and date:

Published: 01/01/1994

DOI:

10.26481/dis.19941014hd

Document Version:

Publisher's PDF, also known as Version of record

\section{Please check the document version of this publication:}

- A submitted manuscript is the version of the article upon submission and before peer-review. There can be important differences between the submitted version and the official published version of record.

People interested in the research are advised to contact the author for the final version of the publication, or visit the DOI to the publisher's website.

- The final author version and the galley proof are versions of the publication after peer review.

- The final published version features the final layout of the paper including the volume, issue and page numbers.

Link to publication

\footnotetext{
General rights rights.

- You may freely distribute the URL identifying the publication in the public portal. please follow below link for the End User Agreement:

www.umlib.nl/taverne-license

Take down policy

If you believe that this document breaches copyright please contact us at:

repository@maastrichtuniversity.nl

providing details and we will investigate your claim.
}

Copyright and moral rights for the publications made accessible in the public portal are retained by the authors and/or other copyright owners and it is a condition of accessing publications that users recognise and abide by the legal requirements associated with these

- Users may download and print one copy of any publication from the public portal for the purpose of private study or research.

- You may not further distribute the material or use it for any profit-making activity or commercial gain

If the publication is distributed under the terms of Article $25 \mathrm{fa}$ of the Dutch Copyright Act, indicated by the "Taverne" license above, 


\section{Fetal asphyxia}

a study in preterm lambs 
Boekverzorging: Bob Joossen-Meyvis, FotoGrafiek, J.R.F., B-2340 Beerse, Belgium Illustratie omslag: Myrthe de Haan: "Zonder titel"

\section{CIP-GEGEVENS KONINKLIJKE BIBLIOTHEEK, DEN HAAG}

Haan, Harmen Hendrik de

Fetal asphyxia, a study in preterm lambs / Harmen Hendrik

de Haan. - [S.I. : s.n.] (Oud-Turnhout : JAP advertising, B-2360). - III

Proefschrift Maastricht - Met lit. opg. - Met

samenvatting in het Nederlands

ISBN 90-9007452-X

Trefw.: foetale asphyxie / verloskunde

Scientifical and financial support by the Janssen Research Foundation and financial support by the Netherlands Heart Foundation

for the publication of this thesis is gratefully acknowledged. 


\section{Fetal asphyxia a study in preterm lambs}

\section{PROEFSCHRIFT}

ter verkrijging van de graad van doctor aan de Rijksuniversiteit Limburg te Maastricht, op gezag van de Rector Magnificus, Prof. Dr. H. Philipsen, volgens het besluit van het College van Dekanen, in het openbaar te verdedigen op vrijdag 14 oktober 1994 om 14.00 uur door

\section{Harmen Hendrik de Haan}

geboren te Drachten op 28 juli 1963 
Promotor: Prof. Dr. J. de Haan

Co-promotor: Dr. T. H. M. Hasaart

Beoordelingscommissie: Prof. Dr. H. A. J. Struijker Boudier (voorzitter)

Prof. Dr. C. E. Blanco

Prof. Dr. A. Jensen,

(Justus Liebig Universität, Gießen, Germany)

Prof. Dr. R. S. Reneman

Prof. Dr. J. Troost 
"Man muß in der Geburtshilfe viel wissen, um wenig zu tun"

Willibald Pschyrembel (1901-1987)

Aan Cynthia Aan Myrthe en Sjors 


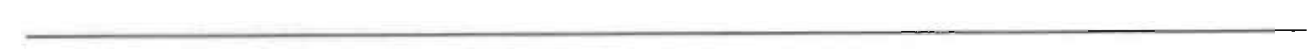




\section{Fetal asphyxia \\ a study in preterm lambs}

\section{Contents}

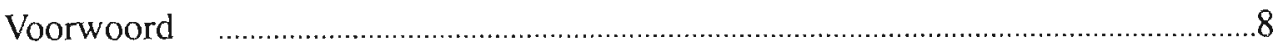

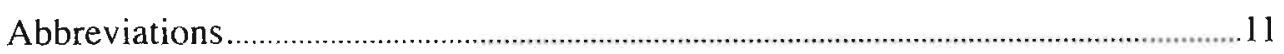

Chapter 1: General introduction and objectives of the study ……......................13

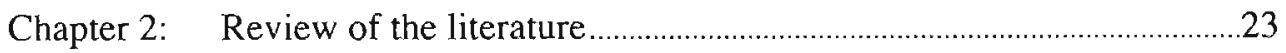

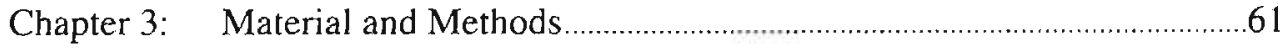

Chapter 4: Possible neuroprotective properties of flunarizine infused after asphyxia in fetal lambs are not explained by effects on cerebral blood flow or systemic blood pressure............73

Chapter 5: The effect of adenosine transport inhibition on cardiovascular function and survival after severe asphyxia in fetal lambs.................87

Chapter 6: Effects of asphyxia on the fetal lamb brain.

Chapter 7: The T/QRS ratio of the electrocardiogram does not reliably reflect well-being in fetal lambs.

Chapter 8: Effects of surgery and asphyxia on levels of nucleosides, purine bases, and lactate in cerebrospinal fluid of fetal lambs

Chapter 9: Summary and conclusions.

Samenvatting en conclusies

Publications

Curriculum vitae. 


\section{Voorwoord}

Het is klaar: En sterker nog: met veel genoegen. Dit door de inbreng van mensen die er op het juiste moment waren om te helpen als ik het niet meer wist. Als eerste Dr. T.H.M. Hasaart, copromotor. Beste Tom, je leverde de ideeën, leerde me schapen opereren en artikelen schrijven, en tussendoor ook nog de verloskunde, zeer veel dank hiervoor.

Prof. Dr. Jelte de Haan, promotor. U leerde mij waardering te hebben voor het wetenschappelijk onderzoek binnen de opleiding tot gynaecoloog, en creëerde voor mij de mogelijkheid beide te combineren. Mijn oprechte dank.

Het onderzoek werd uitgevoerd binnen de' Centrale Proefdier Voorziening van het Bio-Medisch Centrum, waar de hulp van vel'n zeer gewaardeerd is. Met name wil ik noemen Joyce Suyk en May Bost. Opereren w'crd door jullie een genoegen waar ik met veel plezier aan terug denk. De dierverzorging werd grotendeels verricht door Frans Slangen en Peter Franssen.

Uit België, Jos L.H. Van Reempts. Bedankt voor de accuratesse en betrokkenheid waarmee je al de gegevens die uit Maastricht naar Beerse kwamen behandelde. Het vervaardigen en beoordelen van de weefselcoupes, samen met Marc Haseldonckx, het schrijven van de artikelen, en het meedenken. Voor deze laatste twee zaken dank ik ook Prof. Dr. Marcel Borgers. Herman Van Belle wordt bedankt voor het verrichten van bepalingen in serum en liquor cerebrospinalis en voor zijn adviezen in samen geschreven artikelen. Bob Joossen-Meyvis en Lambert Leijssen worden bedankt voor de boekverzorging. Ik houd een zeer goed gevoel over aan de samenwerking met onze westerburen.

Anke C.M. IJzermans, student-assistente. Vele weekenden zaten we in het $B M C$. Dank voor de hulp en gezelligheid tijdens het experimenteren. Irene $M$. Kuipers, AIO bij de afdeling kindergeneeskunde. Tussen de schapen, op symposia en congressen maar vooral ook in de wandelgangen was er een goede samenwerking, waarvoor dank. Dr. Ing. C.M. Verkeste, beste Carla. Je hulp bij de statistiek was broodnodig en werd ten zeerste gewaardeerd. Bovendien was je er altijd op het moment dat het vijf voor twaalf was en ik je op dat moment nodig had. Dr. J.S.H. Vles, beste Hans. Co-auteur en meedenker vanaf het eerste uur. Je las de manuscripten uiterst kritisch en bleef volhouden dat alles positief bedoeld was. Dank. Dr. H. van Huisseling, beste Hans. Eindelijk kreeg ik die occluder eromheen: bedankt voor je hulp bij de eerste operaties. De beoordelingscommissie verdient lof voor het vlot bekritiseren van het manuscript. Met name Prof. Dr. Carlos E. Blanco, die behalve in de beoordelingscommissie ook in de 
wandelgangen, op het BMC en in de kliniek stimulerend werkte. Maurits C.E.F. Wijffels hielp bij de ECG analyse. Jan Geilen was altijd onmiddellijk bereikbaar bij technische calamiteiten. Peter Willemsen voorkwam storingen in de bloedgas machine. Dr. Frits W. Prinzen hielp met het prepareren van de microspheren, en later met de verwerking van telgegevens uit de gamma-counter. Dr. L.L.H. Peeters, beste Louis. Je nooit aflatende enthousiasme en kritische kijk op de wetenschap blijven boeiend en inspirerend. Mede assistenten en ex-assistenten worden bedankt voor het waarnemen van mijn sein als ik even naar de schapen moest, en voor de getoonde belangstelling in het onderzoek. Dit laatste geldt ook voor de stafleden en secretaresses van de afdeling Obstetrie en Gynaecologie. De verpleegkundigen van verloskamers en afdelingen die immer weer benieuwd waren naar mijn schapewereldje. Gerald de Haan en Leo Hofstra, paranymfen, voor het kritisch doorlezen van manuscripten, getoonde interesse, en werkzaamheden rond de promotie.

Ik dank mijn ouders die door hun opvoeding en meeleving zeer veel bijdroegen. Mijn schoonouders voor hun nimmer aflatende aandacht en warmte. Als laatste noem ik het belangrijkste: mijn thuisfront. Myrthe maakte de voorkant van het boekje, dat nu eindelijk klaar is. Sjors, excuses voor mijn tekortkomingen ten opzichte van jou in je eerste levensjaar, ik zal dat zeker goed maken.

Tenslotte Cynthia. Zonder jou was ik zover niet gekomen. Je bent geweldig. Ik hou van je, altijd en overal. 


\section{Abbreviations}

$\begin{array}{ll}\text { ATP } & \text { adenosine 5'-triphosphate } \\ \mathrm{BE} & \text { base excess } \\ \mathrm{CBF} & \text { cerebral blood flow } \\ \mathrm{CSF} & \text { cerebrospinal fluid } \\ \mathrm{CTG} & \text { cardiotocogram } \\ \text { ECG } & \text { electrocardiogram } \\ \text { ECoG } & \text { electrocorticogram } \\ \mathrm{FHR} & \text { fetal heart rate } \\ \mathrm{Hb} & \text { hemoglobin } \\ \mathrm{MBF} & \text { myocardial blood flow } \\ \mathrm{min} & \text { minute } \\ {\left[\mathrm{O}_{2}\right] \mathrm{a}} & \text { arterial oxygen content } \\ \mathrm{Pa} & \text { arterial blood pressure } \\ \mathrm{Pv} & \text { venous blood pressure } \\ \mathrm{PCO} & \text { carbon dioxide tension } \\ \text { post-1 } & \text { post asphyxia 1; time }=90 \text { min } \\ \text { post-2 } & \text { post asphyxia 2; time }=180 \mathrm{~min} \\ \mathrm{SD} & \text { standard deviation } \\ \mathrm{SEM} & \text { standard error of the mean }\end{array}$




\subsection{Introduction}

Perinatal asphyxia is a major concem in obstetrics. The American College of Obstetricians and Gynecologists liability survey in 1992 shows that $79.4 \%$ of members have been sued at least once: $32.6 \%$ of the litigations involved brain-damaged infants, $12.8 \%$ stillbirth or neonatal death, and $12.0 \%$ other major infant injury (1). Also in Europe the scene regarding the legal aspects of malpractice in association with the consequences of perinatal oxygen shortage is changing. Perinatal asphyxia is definitely not the main cause for neurologic disability $(2,3,4)$, but it is a cause theoretically preventable. To prevent asphyxia and optimize perinatal care the fetus is monitored with a variety of methods.

\subsection{Fetal surveillance}

Fetal surveillance is performed using cardiotocography (CTG), in combination with fetal blood sampling, or with recording of fetal body movements and breathing activity. Recently measurement of fetal blood flow velocity waveforms has gained clinical interest.

Soon after its introduction, electronic fetal heart rate (FHR) monitoring in combination with uterine activity recording became widely used in an effort to reduce perinatal mortality and morbidity $(5,6)$. To the description of FHR decelerations, accelerations and changes in basal heart rates, the concept of variability was added, and the ominous significance of decreased variability was established (7). Initial results were hopeful: variable and late decelerations were associated with an increased incidence of low Apgar scores (8) and fetal and neonatal release of catecholamines (9). More recently however, it is shown that FHR patterns poorly correlate with fetal acid-base balance (10). A normal CTG pattern may be regarded to represent fetal well-being and normoxemia, but the occurrence of abnormalities in CTG patterns does not necessarily signify that the fetus is in danger. Use of the CTG is associated with unnecessary operative intervention (11), whereas still children are born damaged by unrecognized asphyxia $(12,13)$. In a large randomized controlled trial CTG monitoring was compared with intermittent auscultation. Neonatal outcome was similar for both groups, except for seizures that were more often present in the intermittent auscultation group (14). These seizures however were not indicative for cerebral palsy during childhood: reassessment of the children when aged 4 , showed that in both groups 3 children had cerebral palsy. An even more important finding was that $16(=78 \%)$ of the 22 children with cerebral palsy at age 4 had not shown any clinical sign suggesting asphyxia at birth (15). Monitoring of all deliveries with CTG compared with monitoring only fetuses at high risk resulted in increased rates of cesarean section because of fetal distress. without improving perinatal outcome in the 34,995 pregnancies monitored (16). Therefore, research is performed to detect parameters with a diagnostic value superior to the CTG.

Serial sampling of micro-amounts of blood from the fetal presenting part enables the obstetrician to divide cases with abnormal CTG traces in fetuses with and 
fetuses without acidemia (17). In the presence of normal FHR variation however, the role of fetal blood sampling is limited (18). Although this technique has gained wide acceptance, its limitations are obvious: membranes have to be ruptured, dilatation is needed, and the presenting part has to be engaged and has to be free from maternal blood and excessive fetal hair. Furthermore, it is a somewhat laborious, invasive technique, considered unpleasant by patients.

Maternal perception of spontaneous fetal movement may be a suitable complementary method to assess fetal well-being, although maternal reporting at times is biased (19). Fetal breathing movements are specific fetal movements, which occur in periods, associated with different stages of activity in utero $(20,21)$, and are present when the fetus shows rapid eye movements and low voltage electrocortical activity (22). A clear relationship is established between lack of fetal breathing movements and fetal asphyxia (23). However, since fetal breathing movements can only be detected ultrasonographically, long periods of observation are necessary. Furthermore, fetal breathing movements diminish or are even absent during labor (24), reducing their usefulness to predict fetal well-being and outcome.

Recently, Doppler measurements were introduced for fetal surveillance. After description of the technique of combining a linear array transducer with a pulsed Doppler system at a fixed angle $(25,26)$ normal values for blood velocities in the descending aorta and the umbilical vein of human fetuses during the third trimester of pregnancy have been produced (27). Initially, a strong association has been suggested between fetal oxygen shortage in growth retardation and mean blood velocity in the fetal aorta (28). However, the same group concluded several years later that accurate estimation of the fetal acid-base balance is not possible with Doppler studies (29). No significant correlation was found between fetal oxygen content and the umbilical artery pulsatility index or between umbilical artery systolic/diastolic ratio and the fetal $\mathrm{pH}$, $\mathrm{PCO}_{2}$, or $\mathrm{PO}_{2}$ (30). However, in fetuses beyond 25 weeks of gestation, in which zero flow was repeatedly determined, fetal hypoxemia was practically always present (31).

In animal experiments changes in the pulsatility index during fetal hypoxemia were not correlated with placental vascular resistance (32). Progressive embolization of the placenta in fetal lambs resulted in hypoxemia and a progressive acidemia that lasted for days, without a proper correlation with the umbilical artery pulsatility index (33). Therefore, it can be concluded from animal experiments as well as from human studies that there is no simple correlation between fetal blood flow velocity parameters and fetal acid-base balance. Clinical decisions should not be made on the base of Doppler assessment of blood flow in pregnancy (34).

In conclusion, accurate determination of fetal well-being and prediction of fetal outcome remains troublesome, in spite of the variety of methods available for fetal surveillance. 


\subsection{Neonatal monitoring at birth}

At birth, asphyxia has to be recognized as soon as possible to start adequate cardiorespiratory resuscitation of the neonate. Clinically, a number of parameters are used to diagnose and evaluate asphyxia, including acid-base balance of arterial blood at birth, and at 30 and 60 minutes after birth, Apgar score, meconium loss, and neonatal neurologic symptoms. Biochemical abnormalities in serum and CSF may give supportive evidence of an asphyxial period.

Severe fetal oxygen shortage will result in anaerobic metabolism, production of lactate, and fetal acidemia. Due to decreased placental gas exchange the PCO2 will increase, resulting in a mixed metabolic and respiratory acidemia. Determination of the acid-base balance from umbilical cord blood immediately after delivery identifies fetuses normally oxygenated during delivery. However, it is shown in a variety of studies that there is a poor correlation between the fetal acid-base balance at birth and the neurologic development of the newborn. None of the neonates with a $\mathrm{pH}<7.00$ and a 1 minute Apgar score $>3$ had either seizures or hypotonia. Conversely, among those with $\mathrm{pH}$ values $\geq 7.00$ and a 1 minute Apgar score $\leq 3$ seven $(=14 \%)$ had hypotonia and two $(=4 \%)$ had seizures (35). Neurologic abnormality at its turn was not related to acidemia at birth either $(36,37,38)$. In conclusion, $\mathrm{pH}$ values between 7.00 and 7.20 have no correlation with any immediate or long-term neonatal morbidity. Most fetuses born with an arterial $\mathrm{pH}<7.00$ will not suffer evidence of perinatal brain damage either. Conversely, such acidemia itself offers no adequate evidence to establish that the observed injury has occurred during labor (39), but will only give supportive evidence for possible intrapartum etiology.

Next to assessment of the umbilical cord acid-base balance, clinical observation of the newborn may provide signs of peripartal oxygen shortage. Although the Apgar score was described originally as a systematic way to evaluate neonatal condition at birth (40), it soon was used as an international standard of perinatal asphyxia (41). Gestational age, maternal medication, infection, congenital disorders affecting the neuromuscular system, and the neonatal cardiopulmonary condition at birth are but a few of the factors that can lead to a low Apgar score without the presence of asphyxia. The sensitivity and the positive predictive value of a low 5 minute Apgar score $(\leq 7)$ to determine adverse neurologic outcome were $12 \%$ and $19 \%$, respectively (38). Of the children with cerebral palsy $26 \%$ had an Apgar score $\leq 3$ at one minute, yet $55 \%$ had a score $\geq 7$. Persistance of a low Apgar score at 10, 15, or 20 minutes, despite resuscitative efforts indicates an ongoing insult that could affect, or further affect, outcome, and is associated with an increased mortality and long-term morbidity (41). In a multivariate analysis of children with cerebral palsy, asphyxia played a role in $9 \%$ of children at the maximum (2). Most infants who had an Apgar score $\leq 3$ at 20 minutes and survived were neurologically impaired. Rapid improvement in scores 
by 5 to 10 minutes indicates that it is unlikely that the prior insult has been sufficiently severe to result in permanent deficit $(41,42)$.

Presence of meconium has also been suggested indicative for severe or prolonged intrauterine stress. The type of meconium (thick or thin, heavy or light) and time of passage (early or late in labor) seemed to be the most significant factors affecting fetal outcome (43). However, expulsion of meconium during labor was present in as much as $18 \%$ of all deliveries, whereas it did not predict neonatal outcome (44). A history of meconium alone did not prove that a term infant experienced a degree of asphyxia sufficient to account for later neurologic sequelae (45).

In conclusion, a variety of factors may suggest perinatal oxygen shortage in the newborn. However, none of them can be regarded as absolutely diagnostic of preceding oxygen lack, since they may reflect other prenatal or intrapartum events or even more fundamental problems of prenatal origin, as, e.g., congenital abnormalities. Although short term morbidity after perinatal asphyxia is important, the golden standard to evaluate perinatal care is long term morbidity, mainly reflected by neurological sequelae.

\subsection{Biochemical parameters of asphyxia in CSF}

There is a large body of literature showing that hypoxanthine is a sensitive indicator of oxygen shortage, maybe even a more specific marker than lactate, base excess, or $\mathrm{pH}$, since it reflects the intracellular energy status $(46,47)$. Levels of hypoxanthine in serum are not very sensitive for brain damage, since the main part of hypoxanthine released during asphyxia originates from the fetal heart and liver (48). However, since neuronal damage leads to the release of intracellular substances into interstitial fluid and into CSF, the level of lactate, hypoxanthine, and xanthine in CSF may give an idea of the severity of the insult and even of neurological prognosis. This was shown after marked hypoxia in cats where peak CSF lactate concentration distinguished animals without brain damage from those that developed cerebral damage with $100 \%$ accuracy (49). Lactate however easily crosses the blood-brain-CSF barrier: during and after asphyxia a net influx of lactate into the cerebrum was observed in exteriorized fetal lambs (50). CSF lactate levels may therefore represent serum lactate levels instead of being indicative for cerebral anaerobic metabolism. Although the specificity of these measurements in CSF may be good, the sensitivity in detecting asphyxial brain damage is low. since infection, infarction and many other processes may elevate the level of these parameters (51). The latter is also true for the elevated levels of hypoxanthine and xanthine in CSF (52). These nucleosides gain importance in the period following asphyxia, since during reoxygenation of the brain hypoxanthine and xanthine act as substrate for oxygen derived free radical formation that aggravates neuronal damage (47). 


\section{Conclusions}

Accurate detection of compromized fetuses remains a major problem in perinatology. Fetal surveillance led to increased obstetrical intervention without improved neonatal outcome. Several parameters are indicative for perinatal asphyxia, but there is not one single test proving that damage observed in the child is due to asphyxia. Knowledge of cardiovascular mechanisms and electrocardial activity during fetal asphyxia is still incomplete, and as a result there remains an inadequate understanding of factors determining neonatal outcome after fetal asphyxia.

\subsection{Objectives of the study}

Review of the literature (chapter 2) gives rise to several unanswered questions. To what extent are certain parameters indicative for fetal condition during and after asphyxia? Can levels of nucleosides or lactate in CSF be used to predict neonatal morbidity? Why is a certain degree of asphyxia lethal to one fetus, causes brain damage in another, and does not seem to have a single negative impact in a completely recovering subject? The factors determining the narrow margin between lethality after asphyxia and survival without signs of histologic damage (53) remain unclear. The questions we addressed after induction of asphyxia in the fetus were:

(I) What is the effect of asphyxia on cardiovascular parameters? (chapters 4,5 and 7)

(II) Are certain cardiovascular parameters indicative for fetal recovery and/or survival after asphyxiia? (chapters 4,5 and 7 )

(III) Can the fetal ECG be used as an indicator for fetal well-being? (chapter 7)

(IV) Does the composition of CSF change during asphyxia, and are certain parameters indicative for cerebral brain damage or fetal survival? (chapters 6 and 8 )

(V) Does this degree of asphyxia lead to histologically confirmed brain damage? (chapter 6)

(VI) Are certain drugs effective in preventing fetal death or histological damage after asphyxia? (chapters 4 and 5) 


\subsection{References}

1. Roberts DK 1993 A guest editorial: medical-legal aspects of placental examination. Obstet Gynecol Survey 48:777-778

2. Nelson KB, Ellenberg JH 1986 Antecedents of cerebral palsy: multivariate analysis of risk. N Engl J Med 315:81-86

3. Blair E, Stanley FJ 1988 Intrapartum asphyxia: a rare cause of cerebral palsy. J Pediatr 112:515-519

4. Nacye RL, Peters EC, Bartholomew M, Landis JR 1989 Origins of cerebral palsy. AJDC 143:1154-1161

5. Hon EH 1959 Observations on "pathologic" fetal bradycardia. Am J Obstet Gynecol $77: 1084-1092$

6. Caldeyro-Barcia R, Méndez-Bauer C, Poseiro JJ, Escarcena LA, Posé V, Biennarz J, Amt I, Gulin L. Althabe O 1966 Control of human fetal heart rate during labor. In: Cassels DE (ed) The heart and circulation in newborn and infant. New York: Grune and Stratton Inc 7-36

7. Hammacher K, Hüter KA, Bokelmann J, Werners PH 1968 Foetal heart frequency and perinatal condition of the foetus and newborn. Gynaecologia 166:349-360

8. Bissonnette JM 1975 Relationship between continuous fetal heart rate patterns and Apgar score in the newborn. Br J Obstet Gynaecol 82:24-28

9. Lagercrantz H, Bistoletti P 1977 Catecholamine release in the newborn infant at birth. Pediatr Res 11:889-893

10. Sykes GS, Molloy PM, Johnson P, Stirrat GM. Tumbull AC 1983 Fetal distress and the condition of newborn infants. Br Med J 287:943-945

11. Haverkamp AD, Orleans M, Langerdörfer S, McFee J, Murphy J, Thompson H 1979 A controlled trial of the differential effects of intrapartum fetal monitoring. Am J Obstet Gynecol 134:399-408

12. Ennis M, Vincent CA 1990 Obstetric accidents: a review of 64 cases. Br Med J 300:1365-1367

13. Murphy KW. Johnson P, Moorcraft J, Pattinson R, Russell V. Turnbull A 1990 Birth asphyxia and the intrapartum cardiotocograph. Br J Obstet Gynaecol 97:470-479

14. MacDonald D, Grant A, Sheridan-Pereira M, Boylan P, Chalmers I 1985 The Dublin randomized controlled trial of intrapartum fetal heart rate monitoring. Am J Obstet Gynecol 152:524-539

15. Grant A. O'Brien N. Joy MT, Hennessy E, MacDonald D 1989 Cerebral palsy among children born during the Dublin randomised trial of intrapartum monitoring. Lancet 2:1233-1236

16. Leveno KJ, Cunningham FG, Nelson S, Roark M, Williams ML, Guzick D, Dowling S, Rosenfeld CR, Buckley A 1986 A prospective comparison of selective and universal electronic fetal monitoring in 34,995 pregnancies. N Engl J Med 315:615-619

17. Saling E. Schneider D 1967 Biochemical supervision of the fetus during labour. J Obstet Gynaecol Br Commonwealth 74:799-811

18. Clark SL, Paul RH 1985 Intrapartum fetal surveillance: the role of fetal scalp blood sampling. Am J Obstet Gynecol 153:717-720

19. Fox HE, Badalian SS 1993 Fetal movement in response to vibroacoustic stimulation: a review. Obstet Gynecol Surv 48:707-713 
20. Patrick J, Natale R, Richardson B 1978 Patterns of human fetal breathing activity at 34-35 weeks of gestational age. Am J Obstet Gynecol 132:507-513

21. Bowes G, Adamson TM, Ritchie BC, Wilkinson MH, Maloney JE 1981 Development of patterns of respiratory activity in unanesthetized fetal sheep in utero. J Appl Physiol 50:693-700

22. Dawes GS, Fox HE, Leduc BM, Liggins GC, Richards RT 1972 Respiratory movements and rapid eye movement sleep in the foetal lamb. J Physiol 220:119-143

23. Boddy K, Dawes GS, Fisher R, Pinter S, Robinson JS 1974 Foetal respiratory movements, electrocortical and cardiovascular responses to hypoxaemia and hypercapnia in sheep. J Physiol 243:599-618

24. Richardson BS, Natale R, Patrick J 1979 Human fetal breathing activity during electively induced labor at term. Am J Obstet Gynecol 1.33:247-255

25. Gill RW 1979 Pulsed Doppler with B-mode imaging for quantitative hlood flow measurement. Ultrasound Med Biol 5:222-235

26. Eik-Nes SH, Brubakk AO, Ulstein MK 1980 Measurement of human fetal blood flow. Br Med J 1:283-284

27. Lingman G, Laurin J, Marsál K 1986 Circulatory changes in fetuse's with imminent asphyxia. Biol Neonate 49:66-73

28. Soothill PW, Bilardo CM, Nicolaides KH, Campbell S 1986 Relation of fetal hypoxia in growth retardation to mean blood velocity in the fetal aorta. Lancet 1:1118-1120

29. Bilardo CM, Nicolaides KH, Campbell S 1990 Doppler measurements of fetal and uteroplacental circulations: relationship with umbilical venous blood gases measured at cordocentesis. Am J Obstet Gynecol 162:115-120

30. Ferrazzi E, Pardi G, Bauscaglia M, Marconi AM, Gementi B, Belotti M, Makowski EL, Battaglia FC 1988 The correlation of biochemical monitoring versus umbilical flow velocity measurements of the human fetus. Am J Obstet Gynecol 159:1081-1087

31. Weiner C 1990 The relationship between the umbilical artery systolic/diastolic ratio and umbilical blood gas measurements in specimens obtained by cordocentesis. Am J Obstet Gynecol 162:1198-1202

32. van Huisseling $H$, Hasaart THM, Ruissen CJ, Muijsers GJJM. de Haan J 1989 Umbilical artery flow velocity waveforms during acute hypoxemia and the relationship with hemodynamic changes in the fetal lamb. Am J Obstet Gynecol 161:1061-1064

33. Muijsers GJJM, Hasaart THM, van Huisseling $H$, de Haan J 1990 The response of the umbilical artery pulsatility index in fetal sheep to acute and prolonged hypoxaemia and acidaemia induced by embolization of the uterine microcirculation. J Dev Physiol $13: 231-236$

34. Low JA 1991 The current status of maternal and fetal blood flow velocimetry. Am J Obstet Gynecol 164:1049-1063

35. Gilstrap LC, Leveno KJ, Burris J, Williams ML, Littlc BB 1989 Diagnosis of birth asphyxia on the basis of fetal pH. Apgar score, and newhom cerebral dysfunction. Am J Obstet Gynecol 161:825-830

36. Dijxhoom MJ, Visser GHA, Huisjes HJ. Fidler V. Touwen BCL 1985 The relation between umbilical $\mathrm{pH}$ values and neonatal neurological morbidity in full term appropriate-for-dates infants. Early Hum Dev $11: 33-42$ 
37. Dennis J, Johnson A, Mutch L, Yudkin P, Johnson P 1989 Acid-base status at birth and neurodevelopmental outcome at four and one-half years. Am J Obstet Gynecol $161: 213-220$

38. Ruth VJ, Raivio KO 1988 Perinatal brain damage: predictive value of metabolic acidosis and the Apgar score. Br Med J 297:24-27

39. Carter BS, Haverkamp AD, Merenstein GB 1993 The definition of acute perinatal. asphyxia. Clin Perinat 20:287-304

40. Apgar V 1953 A proposal for a new method of evaluation of the newborn infant. Anaesthesia and Analgesia 32:260-270

41. Nelson KB, Ellenberg JH 1981 Apgar scores as predictors of chronic neurologic disability. Pediatrics 68:36-44

42. Freeman JM. Nelson KB 1988 Intrapartum asphyxia and cerebral palsy. Pediatrics 82:240-249

43. Meis PJ, Hall M, Marshall JR, Hobel CJ 1978 Meconium passage: a new classification for risk assessment during labor. Am J Obstet Gynecol 131:509-513

44. Nelson KB, Ellenberg JH 1984 Obstetric complications as risk factors for cerebral or seizure disorders. JAMA 251:1843-1848

45. Dijxhoom MJ, Visser GHA, Fidler VJ, Touwen BCL, Huisjes HJ 1986 Apgar score, meconium and acidaemia at birth in relation to neonatal neurological morbidity in term infants. Br J Obstet Gynaecol 93:217-222

46. Saugstad OD 1975 Hypoxanthine as a measurement of hypoxia. Pediatr Res 9:158161

47. Saugstad OD 1988 Hypoxanthine as an indicator of hypoxia: its role in health and disease through free radical production. Pediatr Res 23:143-150

48. Thiringer K, Karlsson K, Rosen KG, Kjellmer I 1984 Contribution of heart muscle, liver, skeletal muscle and placenta to the asphyxial hypoxanthine elevation in the acutely exteriorized fetal lamb. Biol Neon 45:169-182

49. de Courten-Myers GM, Yamaguchi S, Wagner KR, Ting P, Myers RE 1985 Brain injury from marked hypoxia in cats: role of hypotension and hyperglycemia. Stroke 16:1016-1021

50. Thiringer K, Blomstrand S, Hrbek A, Karlsson K, Kjellmer I 1982 Cerebral arteriovenous difference for hypoxanthine and lactate during graded asphyxia in the fetal lamb. Brain Res 239:107-117

51. Harkness RA 1988 Hypoxanthine, xanthine and uridine in body fluids, indicators of ATP depletion. J Chromatography 429:255-278

52. Kjellmer I, Andine P, Hagborg H, Thiringer K 1989 Extracellular increase of hypoxanthine and xanthine in the cortex and basal ganglia of fetal lambs during hypoxia-ischemia. Brain Res 478:241-247

53. Hicks SP 1950 Brain metabolism in vivo. Arch Pathol 49:111-137 


\section{Chapter 2}

\section{Fetal asphyxia, a review of the literature}

2.1. Definition and incidence

2.2. Etiology

2.3. General pathophysiology of fetal asphyxia

2.3.1. Hemodynamic pathophysiology

2.3.2. Metabolic pathophysiology

2.3.3. Cerebral pathophysiology

2.3.4. Hormonal pathophysiology

2.4. Pathophysiology of the myocardium during asphyxia

2.4.1. Myocardial blood flow and metabolism

2.4.2. Adenosine

2.4.3. Fetal electrocardiography

2.5. Pathophysiology of the brain during asphyxia

2.5.1. Acidemia

2.5.2. Glucose levels

2.5.3. Arterial blood pressure

2.5.4. Cerebral blood flow

2.5.5. Oxygen derived free radicals

2.5.6. Calcium

2.5.7. Excitatory neurotransmitters

2.6. Significance of maturity of the fetal brain during asphyxia

2.7. Histologic evaluation of brain damage

2.8. Neonatal outcome

2.9. Treatment

2.10. References 


\subsection{Definition and incidence}

Asphyxia is etymologically derived from a Greek word meaning pulseless. Clinically it refers to the condition after impaired exchange of respiratory gases. Biochemically, asphyxia indicates the combination of oxygen lack with acidemia. Oxygen lack without an accompanying acidemia is called hypoxia (low oxygen tension) or hypoxemia (low percent saturated hemoglobin) (1). Biochemically, asphyxia is described by the degree of acidemia, hypoxemia, hypercapnia, and base excess. Although asphyxia can be exactly defined with these parameters, the clinical presentation of a child born biochemically asphyxiated varies considerably. Several signs and symptoms are associated with asphyxia, but none of them is characteristic for the asphyxiated neonate. This discrepancy between biochemical and clinical asphyxia accounts for misunderstanding and sometimes even for mismanagement of newborns. Furthermore, it does not facilitate comparison of studies in the literature.

In adults, the normal $\mathrm{pH}$ of arterial blood is 7.40 , while the $\mathrm{pH}$ of venous blood and of interstitial fluids is approximately 7.35 , because of extra quantities of carbon dioxide that form carbonic acid in these fluids (2). Compared with adults most fetuses are born with a mixed respiratory and metabolic acidemia, despite a completely normal intrapartum course. In a series of 899 newborns, mean umbilical artery $\mathrm{pH}$ was 7.20 ( $\mathrm{SD} \pm 0.08$ ) with a mean base excess of $-8.3 \mathrm{mM}$ $(\mathrm{SD} \pm 4.0)(3)$. In a series of 2,738 singleton live births at term complicated by either cesarean section, forceps delivery, meconium passage, oxytocin stimulation of labor, or abnormal FHR pattern the incidence of asphyxia was $0.6 \%, 2.8 \%$ and $6.0 \%$, when asphyxia was defined as umbilical artery $\mathrm{pH}$ values $<7.00, \mathrm{pH}<7.10$, and $\mathrm{pH}<7.15$, respectively (4). When a blood base excess of $-12 \mathrm{mM}$ was taken as a criterion for fetal asphyxia, the prevalence of intrapartum asphyxia was $2 \%$ in the term fetus (5), and $6 \%$ in preterm fetuses less than $2000 \mathrm{~g} \mathrm{(6)}$.

\subsection{Etiology}

Fetal asphyxia is caused by impaired placental gas exchange. This may be of fetal or maternal origin, or caused by placental malfunctioning. Fetal causes are umbilical cord compression, myocardial decompensation and forward failure, or anemia. Maternal causes include uterine hyperactivity, congestive heart diseases with forward failure, and severe anemia. All these processes lead to an insufficient uterine perfusion and an impaired placental gas exchange. Placental reasons for fetal asphyxia are abruptio, and an inadequate function of the placenta due to impaired placentation, infection, or infarction.

\subsection{General pathophysiology of fetal asphyxia}

\subsubsection{Hemodynamic pathophysiology}

The effect of asphyxia on the fetal cardiovascular system is extensively investigated in animal experiments. The main part of this research is performed in 
fetal sheep, in which species asphyxia is induced either by reduction of maternal uterine perfusion, by umbilical blood flow restriction, or by maternal inhalation of a hypoxic gas mixture.

The common fetal cardiovascular response to acute oxygen shortage is hypertension and bradycardia $(7,8)$. Fetal arterial blood pressure usually increases slowly over several minutes, the rise being more rapid and marked when oxygen shortage is severe $(7,8)$. The association of bradycardia and hypertension suggests the bradycardia being the result of a baroreflex response to hypertension. This hypothesis was supported by studies in fetal sheep, in which umbilical cord occlusion resulted in bradycardia with arterial hypertension (9). Before the baroreceptors are functionally active the peripheral chemoreceptors (aortic and carotid bodies) have been demonstrated to mediate the bradycardic response to acute oxygen shortage (10). These chemoreceptors co-activate parasympathetic and sympathetic pathways, as is shown in Figure 2.1 .

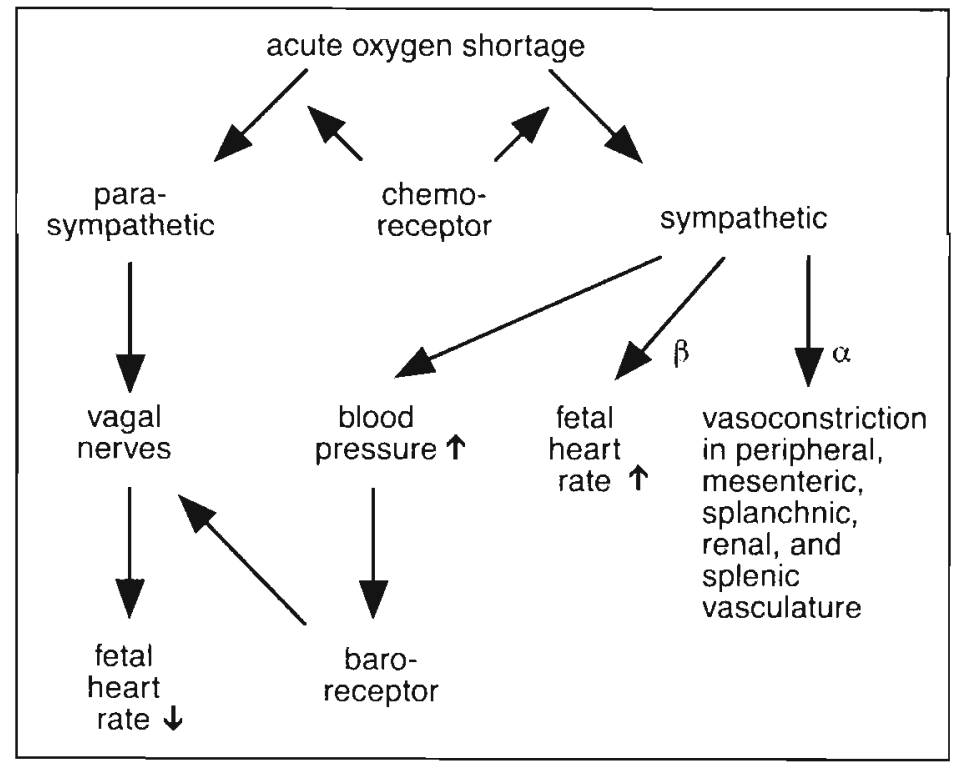

Figure 2.1. The effect of acute oxygen shortage on the fetal cardiovascular system.

When sympathetic efferents are transsected at Th12 level, hypoxemia no longer produces a rise in arterial blood pressure, but the fall in FHR persists since vagal influences are intact $(11,12)$. The same is observed after pharmacologic blockade of the alpha-adrenergic system during reduced uterine perfusion in sheep (13). During oxygen shortage alpha-adrenergic activity promotes vasoconstriction of the peripheral, mesenteric, splanchnic, renal, and splenic vasculature (7). Increased beta-adrenergic activity supports the FHR and maintains placental bloud flow (14). When chemoreceptors are subjected to ascending aortic blood $\mathrm{PO}_{2}$ 
values $<2.4 \mathrm{kPa}$, bradycardia will result (15). After sinoaortic denervation sympathetic mechanisms dominate, leading to a tachycardic response during hypoxia, while cardiac output and fetal blood flow distribution remain unchanged (16). Both the chemoreflex and the baroreflex induced bradycardia are mediated through vagal stimulation (17).

When oxygen shortage persists, fetal catecholamines are released from the adrenal glands, leading to tachycardia (18). This tachycardia may also be due to a concomitant hypercapnia, which reduces the vagal activity and thereby enhances sympathetic increment of the FHR (19). Hemodynamic adjustments during prolonged fetal oxygen shortage are summarized in Figure 2.2.

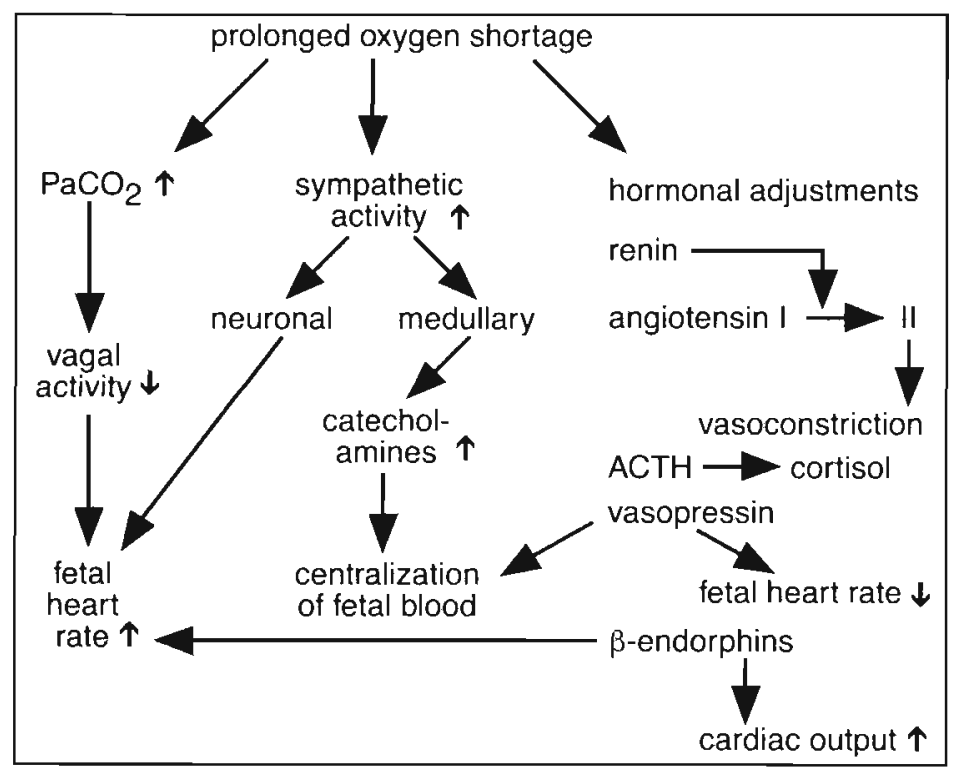

Figure 2.2. The effect of chronic oxygen shortage on the fetal cardiovascular system.

Dramatic changes in the distribution of cardiac output take place. During oxygen shortage the increased blood flow to the myocardium, brain and adrenal glands, called centralization of fetal blood (20), occurs at the expense of reduced perfusion of liver, kidney, gastro-intestinal tract, muscle, carcass and skin. Perfusion of the placenta remains unchanged (21). This redistribution of the fetal circulation occurs rapidly (22), and in the absence of progressive metabolic acidemia the sheep fetus can maintain these protective circulatory adjustments for up to 48 hours (23). Next to this redistribution of cardiac output, well-oxygenated blood from the ductus venosus is preferentially directed across the foramen ovale to provide the myocardium and the brain with an increased proportion of the most oxygenated blood during periods of asphyxia $(17,24)$. 


\subsubsection{Metabolic pathophysiology}

The main metabolic response to oxygen shortage is anaerobic glycolysis. Classic studies in fetal lambs demonstrate a linear relationship between survival after asphyxia and the size of the glycogen stores in liver and myocardium (25). Anaerobic glycolysis implies an inefficient use of energy supplies in comparison with aerobic metabolism. During normal oxidative metabolism one molecule of glucose leads to 36 molecules of ATP, whereas anaerobic metabolisin only leads to formation of lactate, $\mathrm{NAD}^{+}$, and two molecules of ATP (2). Obviously, anaerobic glycolysis is a short-term rescue mechanism that produces accumulation of lactate in tissues and blood (26). The gradually increasing concentration of lactatc leads to metabolic acidemia (25). Increased fetal plasma lactate concentrations become a more important source of substrate for the placenta, and may even reduce placental glucose consumption (27).

The inability of anaerobic glycolysis to maintain ATP regeneration results in usage of the energy-rich intracellular phosphates. This process is quantitatively reflected in an augmented plasma level of hypoxanthine $(28,29)$. The origin of serum hypoxanthine in asphyxiated lamb fetuses is multiple: a dominant release from liver and skeletal muscle early during asphyxia, at a more severe stage of asphyxia followed by release from the myocardium, and only at the most severe stage of asphyxia a release from the central nervous system $(30,31)$.

\subsubsection{Cerebral pathophysiology}

Theoretically two adaptations can maintain cerebral oxygen consumption during asphyxia: (I) the brain may extract more oxygen from the delivered blood, or (II) cerebral blood flow may increase. Although both in immature fetal lambs (32) and in newborn lambs (33) fractional oxygen extraction increases during oxygen shortage, the brain largely relies on blood flow increment. The rise in cerebral blood flow has a twofold effect: first, maintenance of tissue oxygen delivery, defined as the product of arterial oxygen content and blood flow, and second, decreasing the arteriovenous oxygen difference across the brain, thereby increasing capillary oxygen tension, which is the driving force for oxygen diffusion. Additional adaptations in situations with chronic oxygen shortage are elevated $\mathrm{Hb}$ concentrations (34) and an increase of the number of capillaries in muscles $(34,35)$.

Cerebral reaction mechanisms to asphyxia can be divided in two major stages. The first stage occurs initially, before oxygen shortage has become too severe, and is characterized by mechanisms to keep up oxygen supply to the brain and maintain aerobic cerebral metabolism. As described above, blood flow to the brain is augmented $(7,21)$, and additionally cerebral blood is redistributed providing the highest flow to phylogenetically older brain structures as thalamus, cerebellum and medulla oblongata $(21,36,37)$. The second stage is reached when oxygen delivery to the brain is insufficient. Cerebral oxygen shortage severe 
enough to produce irreversible tissue injury is always associated with major disturbances in the energy status of the brain $(38,39)$. The main energy consuming processes in the brain are (I) turnover of membrane lipids and proteins and (II) maintenance of the membrane potential. Turnover is energy consuming due to the magnitude of the nervous system: some axon terminals are at one meter distance from its cell-body. Furthermore, the brain largely consists of lipids: $75 \%$ of myelin, $55 \%$ of white matter, and $35 \%$ of grey matter is of lipid origin (40). Membrane lipids contain mainly unsaturated fatty acids that are sensitive for oxidation, a process easily occurring in the adequately oxygenated brain. Maintenance of the membrane potential is essential for neuron functioning, since communication between neurons is dependent on depolarization and repolarization.

Table 2.1. Relative concentration differences between extracellular and intracellular (neuronal) ions

\begin{tabular}{|l|c|c|}
\hline ion & extracellular & intracellular \\
\hline $\mathrm{Na}^{+}$ & 14 & $\mathrm{I}$ \\
$\mathrm{K}^{+}$ & 1 & 30 \\
$\mathrm{Ca}^{2+}$ & 10,000 & $\mathrm{I}$ \\
\hline
\end{tabular}

During physiological conditions, a stimulation opens specific sodium and calcium channels, and due to concentration differences (summarized in Table 2.1) ions enter the neuron. Because of these ion shifts, the membrane potential increases from $-60 \mathrm{mV}$ to approximately $0 \mathrm{mV}$ : depolarization. The next step is closure of these channels, opening of potassium channels, efflux of potassium and restorage of the membrane potential: repolarization. After these events the concentration differences are actively built up again with aid of the ATP consuming $\mathrm{Na}^{+} / \mathrm{K}^{+}$-pump (40). These processes are schematically shown in Figure 2.3 .

Reduction of uterine blood flow to $25 \%$ of normal results in generalized vasoconstriction of fetal cerebral and myocardial vasculature (41). If the latter condition persists this may lead to fetal decompensation. The cerebrum catabolizes the high-energy phosphate compounds of the cells, and severe impairment of the electrical function of the neurons takes place. Spontaneous electroencephalograpic activity has already ceased (42), but at this stage also the cortical evoked potentials vanish (30). This disruption of neurophysiological activity during asphyxia is related to various events. Synaptic transmission is impaired because of reduced synthesis and release of excitatory transmitter substances such as noradrenaline and dopamine (43). Energy lack leads to reduced $\mathrm{Na}^{+} / \mathrm{K}^{+} /$ATP-ase activity with an incapability of the neuronal cell membrane to maintain electrical stability. Leakage of potassium ions into the extracellular space of the brain and of calcium ions into the cytosol of the neurons and into mitochondria takes place (Figure 2.3) as the ultimate result of cellular energy crisis $(44,45)$. This was confirmed in the micro- 


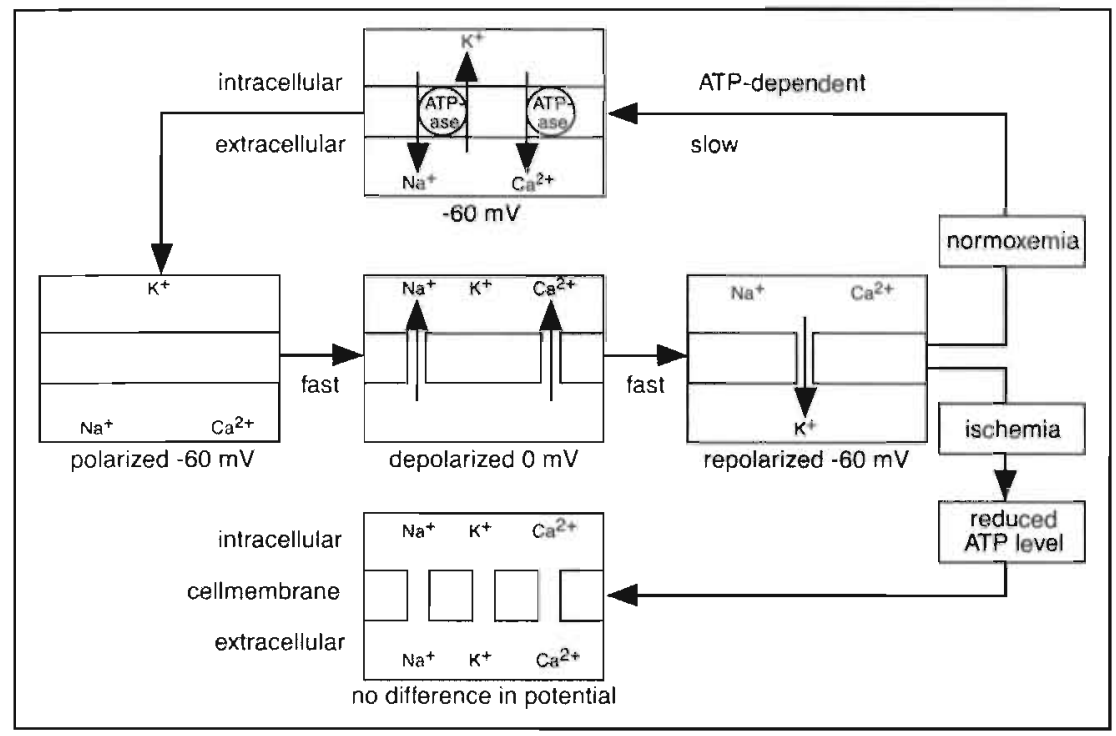

Figure 2.3. The depolarization-repolarization cycle. During normoxemia ion pumping after repolarization leads to normal concentrations of ions on both sides of the neuronal membrane. During energy shortage this normalization cannot be achieved and the membrane remains depolarized.

scopic studies of Brown and Brierley (46), indicating that the earliest morphologic alteration of the neuron arising from oxygen shortage is a dilation of mitochondria. To reduce cellular acidosis, hydrogen ions are exchanged for sodium ions, which further increases the amount of intracellular sodium. As a result there is a water influx into the neuron, leading morphologically to cytotoxic cerebral edema. Alterations in intracellular ion concentrations, intracellular edema, and in cell lysis lead to primary neuronal death, referring to irreversible loss of neurons during the insult itself. Other processes do not lead to neuronal loss for some considerable time after the insult. This secondary neuronal death may be a result of inappropriate activation of programmed cell death, the so-called apoptosis (47), of activation of inflammatory cells (48), and of changes in the neuromodulatory system (49) leading to excitotoxicity (50) and activation of oxygen derived free radicals. At the final stage of oxygen shortage, immediately before death, the blood-brain barrier function decreases, resulting in more cerebral edema. Figure 2.4 shows a schematic representation of a neuron demonstrating the processes important during lack of oxygen. 


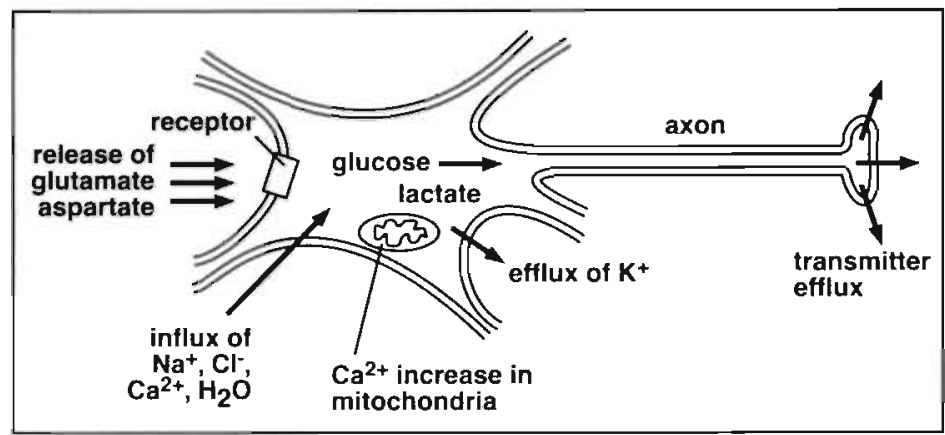

Figure 2.4. Schematic representation of a neuron suffering from oxygen shortage. Ionic and transmitter fluxes are discussed in the text.

\subsubsection{Hormonal pathophysiology}

Several hormones and vaso-active compounds are released during sustained oxygen shortage (Figure 2.2). During the stress of normal vaginal birth the fetus reacts with a release of catecholamines (51). The level of catecholamines reaches values many times higher when the nconate has been the subject of perinatal asphyxia (52). In animal research evidence is collected that fetal circulatory and hormonal responses to asphyxia are partly due to a rise in plasma catecholamines $(18,27,53)$. Fetal sheep depend on intact beta-adrenoreceptor mechanisms to be able to cope with asphyxia of a moderate degree (54).

Acute reductions in uterine blood flow in pregnant sheep are associated with a very large and transient increase in fetal plasma adrenocorticotropin hormone (ACTH) concentrations coincident with the degree of acidemia (55). Since the fetal adrenal cortex becomes progressively more sensitive to the stimulatory effects of ACTH in the last part of gestation, glucocorticoid levels rise during gestation and undergo a dramatic upsurge 1 to 2 days before parturition (56). Severe acidemia induced by intravenous infusion of $\mathrm{H}^{+}$in fetal sheep leads to increased levels of ACTH and cortisol, but does not alter fetal plasma renin activity or fetal blood pressure (57). More severe oxygen shortage however does increase plasma renin activity (58). Renin converts angiotensin I to angiotensin II, which is a potent vasoconstrictive homone.

The rise in vasopressin observed during induced acidemia (57) and during hypoxemia causes bradycardia and a circulatory centralization (59).

Fndogenous opioids are a group of naturally occurring peptides that are involved in the regulation of cardiovascular and other physiological functions. The endogenous opiate system acts by modulating the vasoconstiction in fetal carcass and kidncys induced by vasoconstrictor substances, released as a response to asphyxia (60). In this regard, it has been reported that endogenous opioids decrease the release of vasopressin from the neurohypophysis (61) and of catecholamines from the adrenal medulla (62). Finally beta-endorphins, a subgroup of endogenous opiates, lead to tachycardia and an increased cardiac output (63). 


\subsection{Pathophysiology of the myocardium during asphyxia}

\subsubsection{Myocardial blood flow and metabolism}

Under normal physiological conditions oxygen supply to the fetal lamb is approximately twice the value necessary to maintain an adequatc fetal oxygen uptake and a normal fetal base excess (64). When uterine blood flow is decreased to $75 \%$ of baseline, combined fetal ventricular output and regional blood flows are not different from normal (4l). More severe reduction of uterine perfusion will result in fetal asphyxia. To maintain oxygen delivery to the most vital organs during asphyxia, the fetus resorts to physiologic mechanisms that cause a preferential redistribution of the well-oxygenated blood to sustain the heart, brain, and adrenal glands, and maintain blood flow to the placenta $(17,21)$. At modest degrees of oxygen shortage it has been shown in the myocardium and the brain that the increase in blood flow matches the reduced oxygen delivery, resulting in a constant oxygen uptake by these vital organs $(65,66)$. Moreover, fetal oxygen consumption during severe asphyxia decreases, which is presumed to reflect a reduced uptake of oxygen in the vasoconstricted organs and areas $(27,64,67)$. The increase in blood flow to myocardium, brain, and adrenals is primarily regulated by direct local vascular effects (16). When the fetal $\mathrm{pH}$ reaches 7.00 combined ventricular output decreases. If the $\mathrm{pH}$ further decreases and reaches values around 6.86 , redistribution of fetal blood fails, the perfusion of placenta, heart and brain decreases, and cardiovascular collaps will occur (68). Severe reduction of uterine perfusion ( $25 \%$ of baseline) leads to decreased fetal myocardial blood flow prior to cardiovascular collapse (41).

\subsubsection{Adenosine}

It goes beyond the scope of this thesis to discuss all hormonal and paracrine substances produced during asphyxia. Due to its beneficial effects after asphyxia an exception is made for adenosine. Whenever there is a mismatch in the myocardium between energy supply and energy demand, nucleotides (e.g., ATP, ADP, AMP) are rapidly degraded by consecutive dephosphorylation $(69,70)$. The amount of nucleotides catabolized is directly related to the duration of ischemia and may reach $40 \%$ to $50 \%$ within 30 minutes of normothermic myocardial ischemia in dogs (71). Adenosine accumulates in the myocardial interstitium where it can exert its function, or can be catabolized in either the endothelial cell or in the vascular lumen (70). This is summarized in Figure 2.5.

Accumulation of adenosine within the interstitium of the myocardium is transient because of its rapid metabolism in endothelial cells (72). Production and release of adenosine in response to oxygen shortage may be an important natural defense system in the myocardium (and probably also in other vital organs, such as the brain and kidneys). 


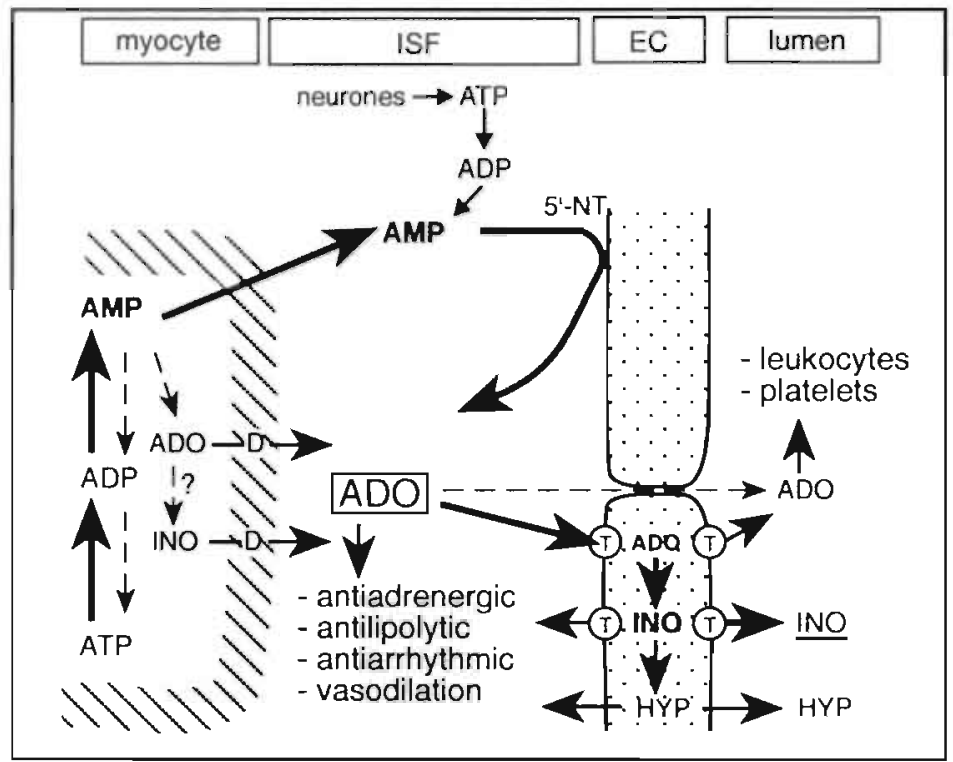

Figure 2.5. Formation and metabolism of adenosine $(A D O)$ in the myocardium. Oxygen shortage leads to AMP accumulation in the myocyte. Cytosolic dephosphorilation may lead to intracellular formation of adenosine, which leaves these cells by diffusion $(D)$. More probably, interstitial fluid (ISF) adenosine originates from extracellular nucleotides (AMP from myocytes, ATP from nerve endings or endothelial cells). In the ISF adenosine has access to several targets on the surrounding cells. Whereas some adenosine may reach the lumen of the microvasculature through clefts between endothelial cells $(E C)$, the majority of adenosine is taken up in these cells via diffusion, facilitated by the nucleoside transporter $(T)$, and entensively catabolized. Reproduced with permission (72).

Pretreatment with similar repeated brief periods of ischemia trigger adaptive changes that protect the myocardium from the effects of a subsequent, prolonged ischemic insult, and reduce infarct size (73). In this ischemic preconditioning a central role for adenosine is presumed $(73,74)$. The latter was confirmed after prolonged ischemia in dogs, where intracoronary administation of adenosine, after reperfusion, improved regional ventricular function in the ischemic zone (75). This benefit is explained by a range of pharmacological properties: (I) Adenosine is an important coronary vasodilator (76). An enlarged diameter of microvessels may allow passage of microemboli that may contribute to the no-reflow phenomenon in the ischemic/reperfused myocardium (77). (II) Adenosine inhibits the release of catecholamines (78), and modulates the effect of catecholamines (79), and therefore reduces the nutrient and oxygen demand of the myocardium. (III) Adenosine inhibits platelet aggregation (80). Infusion of adenosine antagonists during hypoperfusion in dogs led to a rapid decrease in coronary blood flow, 
attributed to thromboembolism (81). (IV) Leukocytes, infiltrated in the myocardium during hypoxia-ischemia, are activated. These leukocytes may physically obstruct the microvessels during reperfusion or may even release oxygen derived free radicals and a whole array of proteolytic enzymes (82). Adenosine is known to inhibit these processes (83). (V) Furthermore, adenosine is used as an antiarrhythmic agent, known to terminate paroxysmal supraventricular tachycardias, and therefore protects the heart against excessive energy demands (84).

\subsubsection{Fetal electrocardiography}

The human fetal ECG can be recorded since 1906 (85). After improvement of analyzing and recording equipment the fetal ECG gained clinical interest. The human fetal ECG was studied during increased asphyxia in induced abortions (86). A few years later the first recordings during labor are reported, and it was postulated that fetal ECG changes could be due to impaired fetal oxygenation (87). In his study concerning the changes of the ECG of the dying fetus. Hon focuses on PR interval changes, on widening QRS complexes, and on S-T segment depressions (88). Also the electrical axis of the fetal heart is suggested as a criterion for fetal condition (89). However, a clear relationship between fetal condition and certain ECG parameters could not be established.

The fetal ECG regained interest in clinical obstetrics when appropriate baseline noise filters and signal processing became available (90). In response to hypoxia the ratio of the $T$ wave height to the QRS complex height (T/QRS ratio) increases in studies in fetal lambs $(91,92,93)$. This increment of the T/QRS ratio is considered to represent a change to anaerobic myocardial metabolism (91), secondary to beta-adrenergic stimulation (92). However, in the studies mentioned above oxygen shortage does not lead to anaerobic fetal metabolism and acidemia. This is peculiar, because if the T/QRS ratio is ever going to be used in fetal surveillance, experiments with severely asphyxiated fetuses should have been performed. Especially, since the severity of asphyxia is associated with the level of neonatal morbidity and mortality $(94,95)$.

Recent clinical studies on the T/QRS ratio are not unequivocal. None of the neonates born in a poor condition (one minute Apgar score $\leq 3$ ) or with evidence of acidemia had a mean T/QRS ratio significantly different from the normal range (99). A raised T/QRS ratio had a considerably lower detection rate for fetal acidemia than a pathological CTG (97). A weak correlation is found between the T/QRS ratio and umbilical artery acidemia (98). Other results are promising: in a large randomized trial the combination of CTG with T/QRS ratio analysis did not lead to neonates born in a better condition, but was associated with a $50 \%$ reduction of operative deliveries for fetal distress $(99,100)$. Regarding this $50 \%$ decrease it should be kept in mind that introduction of fetal surveillance with CTG led to a $50 \%$ increase of operative deliveries for fetal distress, even when the CTG was complemented by selective fetal blood sampling and acid-base 
balance assessment $(101,102,103)$. It is obvious that fetal ECG monitoring is restricted to surveillance during labor, since an electrode placed directly on the fetal presenting part is a prerequisite for a technically acceptable recording. But even with an optimal recording extensive research needs to be directed toward severely asphyxiated fetuses to elucidate the value of the ECG in fetal surveillance.

\subsection{Pathophysiology of the brain during asphyxia}

\subsubsection{Acidemia}

Many studies are designed to investigate the effects of hypoxia on fetal variables. Reduced placental perfusion however not only leads to hypoxia, but moreover complicates the release of carbon dioxide from the fetus, resulting in respiratory acidemia. Anaerobic glycolysis leads to a gradual accumulation of pyruvate and lactate and to the development of a non-carbonic, metabolic acidemia. Intrauterine asphyxia therefore constitutes of a mixed metabolicrespiratory acidosis. Increased severity of asphyxia in fetal sheep leads to deterioration of fetal cerebral activity, measured with evoked potentials. The combination of oxygen shortage with a normal $\mathrm{pH}$ does not seriously affect the evoked potentials (104). Fetal acidemia itself, induced by infusion of lactic acid to achieve arterial $\mathrm{pH}$ levels around 6.88, did not lead to severe deterioration of cerebral function in the absence of concomitant hypoxia (105).

\subsubsection{Glucose levels}

During oxygen shortage hyperglycemia leads to the formation of high levels of lactate that reduce the tolerance of the brain during this event. The latter has been demonstrated in a variety of animal models: hyperglycemic rhesus monkeys produced more lactate during complete ischemia by means of circulatory arrest, and had a more pronounced deterioration of cerebral functions than their normoglycemic and hypoglycemic controls (106). This phenomenon is confirmed in experiments with hyperglycemic cats exposed to severe oxygen shortage, who underwent a neurologic deterioration in the hours following reoxygenation (107). The latter was correlated with inhibition of mitochondrial respiration, increased tissue lactate levels and decreased energy state (108). Conversely, hypoglycemia (in experiments with adult rats that fasted shortly before incomplete brain ischemia) resulted in lower cerebral lactate levels and better cerebral outcome compared with animals that were pretreated with intravenous glucose (109).

Also in humans the level of serum glucose during oxygen shortage is correlated with neurologic sequelae. After cardiac arrest, comatous patients with a marked hyperglycemia have a greater risk to develop permanent severe deficits (110). Women with fasting hyperglycemia are at greater risk for fetal death (111). In a study of 766 newborns who weighed $>4,500$ g perinatal mortality was $7 \%$, 
$16 \%$ were severely depressed at birth, and $11 \%$ had severe neurological complications. Macrosomia itself and the related birth injury could not explain the adverse outcome observed (112). On the other hand also growth-retarded fetuses appeared to be more susceptible to asphyxia than adequately grown fetuses, both in clinical studies (113) and in animal experiments (114). Within the intrauterine growth retarded (IUGR) group, the disproportionate (low Ponderal index) IUGR group has higher neonatal morbidity (hypoglycemia, perinatal asphyxia, hypothermia, fetal distress and meconium aspiration) than the proportionate IUGR group $(113,115)$. Since anaerobic myocardial metabolism during asphyxia is dependent on glycogen stores (25), it is suggested that the group of disprportionate IUGR fetuses has a reduced ability to adapt during asphyxia, simply because of lower metabolic reserves (113).

In conclusion, during intrauterine asphyxia hyperglycimia will lead to increased production of lactate, whereas chronic hypoglycemia may result in lower metabolic reserves and a decreased functioning of compensatory mechanisms. Both glycemic states are therefore associated with worse cerebral outcome compared to normoglycemic fetuses.

\subsubsection{Arterial blood pressure}

Increased extracellular volume increases blood volume and filling pressure, which increases the venous return to the heart, leading to increased cardiac output and elevated arterial blood pressure. When tissue is perfused by an excessive amount of blood, local vasoconstriction decreases blood flow to normal values. This phenomenon is called autoregulation, which means regulation of blood flow by the tissue itself (116). Between the pressure limits of 60 and 140 $\mathrm{mm} \mathrm{Hg}$ acute changes in arterial blood pressure will not lead to changes in cerebral blood flow. In patients with hypertension this cerebral blood flow autoregulatory range shifts to even higher pressure levels, up to as high as 180 to $200 \mathrm{~mm} \mathrm{Hg} \mathrm{(116).}$

If the arterial blood pressure falls below the limit of autoregulation, cerebral blood flow becomes severely compromized. This is confirmed in pretern fetal lambs: cerebral blood flow is linearly related to mean arterial blood pressure from 18-45 $\mathrm{mm} \mathrm{Hg}$, constant between $45-80 \mathrm{~mm} \mathrm{Hg}$, and again linear from 80-90 $\mathrm{mm} \mathrm{Hg}(117)$. In midgestational sheep fetuses with a mean arterial blood pressure less than $30 \mathrm{~mm} \mathrm{Hg}$ during oxygen shortage (i.e., below the limit of autoregulation), serum lactate concentrations were elevated to excessive high values and, more important, brains were markedly damaged (118). In asphyxiated fetal lambs neuronal damage was strongly associated with the percentage decrease in blood pressure during the insult (119). In cats exposed to 25 minutes of marked hypoxia, animals that maintained their blood pressure were cerebrally undamaged, whereas hypotensive animals showed severe neuronal necrosis (120). 
If the arterial blood pressure rises above the upper limit of autoregulation, cerebral blood flow rises rapidly (117) and can cause severe overstretching of cerebral blood vessels, sometimes resulting in serious brain edema (2) or hemorrhages (121). Intermittent increases of intravascular pressure in combination with asphyxia indeed caused hemorrhages in the germinal layer of the fetal sheep brain (122).

Following prolonged asphyxia local cerebral recirculation may not be restored upon reoxygenation. This effect has been described as the no-reflow phenomenon. Cytotoxic edema due to asphyxia is thought to collapse capillaries and thus impede reperfusion $(123,124)$. An elevated blood pressure observed after a variety of insults may be necessary to open collapsed capillaries and facilitate reperfusion (125).

\subsubsection{Cerebral blood flow}

Next to severe arterial hypertension and hypotension, a variety of factors can affect cerebral blood flow (Figure 2.6). The question remains how this multitude of factors precisely regulates brain blood flow under various conditions (126).

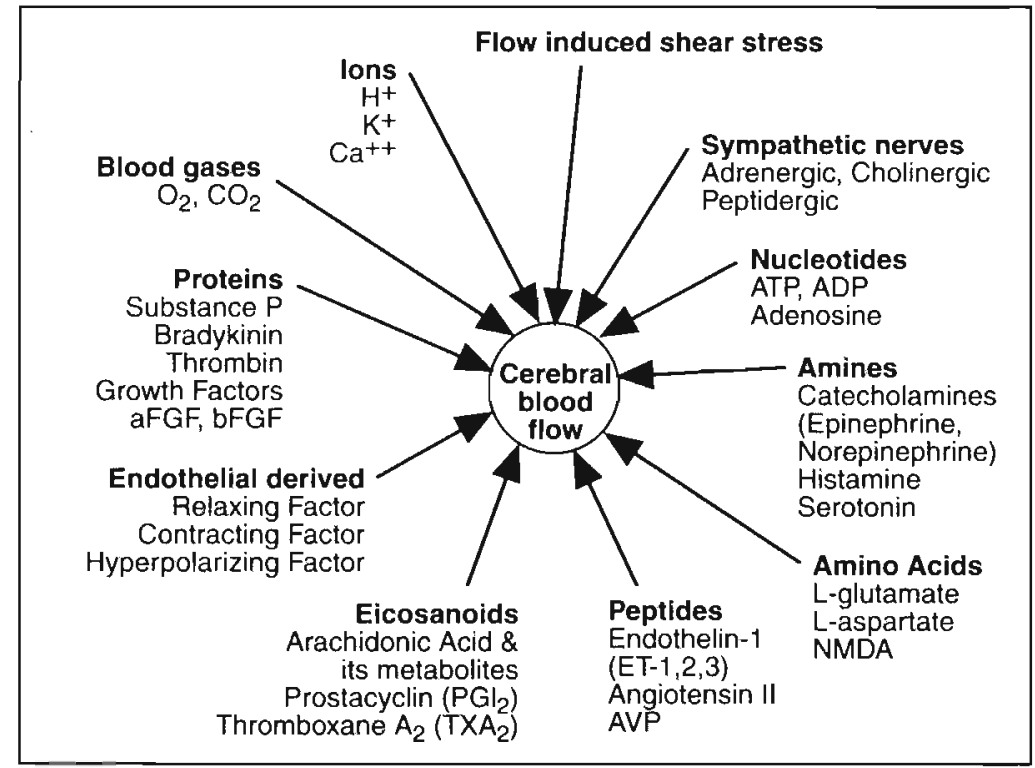

Figure 2.6. Factors playing a role in the regulation of cerebral vascular tone and blood flow. Reproduced with permission (126)

During hypoxemia oxygen delivery to the brain is generally maintained by increment of cerebral blood flow, although some variability in responses between various experimental protocols is reported (127). Blood flow to different regions within the brain also varies. Flow to phylogenetically older areas as medulla oblongata, pons, and subcortex is increased compared with cortical flow. This 
distribution remains intact during oxygen shortage (23). However, if cerebral oxygen delivery decreases, normal cerebral oxygen consumption is maintained due to a proportional increase in cerebral fractional oxygen extraction, both in immature fetal lambs (32) and in neonatal lambs (33). Although not resembling pathophysiology of human intrauterine asphyxia, an experimental design was developed which combined oxygen shortage with decreased cerebral perfusion. Unilateral carotid artery ligation in rats in combination with inhalation of a hypoxic gas mixture led to significantly more damage in the ischemic cerebral hemisphere (128). Recently this model is modified for fetal sheep. Ligation of the vertebral-carotid anastomosis and inflation of occluder cuffs around both carotid arteries for 30 minutes results in ischemic encephalopathy (129). The effect of unilateral cerebral ischemia can be evaluated due to the morphologic differences between both hemispheres. The major disadvantage of these ischemic models is the difference from clinical pathophysiology: oxygen shortage normally leads to acid-base balance changes and increased cerebral blood flow, but in these ischemic setups fetal metabolic condition does not change, and cerebral blood flow is reduced.

Excessive brain swelling is thought to occur secondarily to cytotoxic (intracellular) edema as a result of increased permeability of the capillaries, leading to accumulation of fluid in the extracellular space (124). This cerebral edema can increase intracranial pressure to the point of impeding cerebral blood flow. Intracranial pressure reaches a maximum at 36 to 72 hours after a severe asphyxial insult in neonates (130).

\subsection{Oxygen derived free radicals}

A free radical is an atom or molecule that contains an odd number of electrons in its outer most orbit. If a radical reacts with a non-radical another free radical is produced. This characteristic enables free radicals to participate in chain reactions, which may be thousands of events long. During normal oxidative processes a small proportion of the oxygen utilized is converted into free radicals: the superoxide ion $\left(\mathrm{O}_{2}\right)$, the related hydrogen peroxide $\left(\mathrm{H}_{2} \mathrm{O}_{2}\right)$, and the hydroxyl radical $(\mathrm{OH})$. These potentially destructive agents are extremely reactive, may damage membrane structures, and may also lead to direct injury of the cellular DNA (131). During normal oxidative metabolism, defense mechanisms against the potential damaging effect of oxygen derived free radicals are provided by endogenous scavengers, including enzymes (superoxide dismutase, catalase, and peroxidase), cholesterol, vitamin $E$, vitamin $C$, and glutathione (39). These scavengers prevent the accumulation of high concentrations of oxygen derived free radicals that would lead to tissue damage and to the formation of the most highly reactive radical, the hydroxyl radical $(132,133)$ (Figure 2.7 ).

Oxygen derived free radicals are formed during arachidonic acid metabolism (see ad. 2.5.6), but also in the period following asphyxia. During 
asphyxia energy rich nucleotides are rapidly catabolized (134), which results in the accumulation of hypoxanthine and xanthine both in circulating blood and in tissues, including the brain (30). When oxygen is added to a system rich in hypoxanthine and xanthine, oxygen derived free radicals are formed in large quantities, provided the enzyme xanthine-oxidase is available (135). This enzyme is generally not present but can be transformed from xanthine-dehydrogenase. This transformation takes place in the liver (136) and in endothelium of brain capillaries (137), is induced by oxygen shortage and by an increase of intracellular calcium ion concentrations, which in turn is caused by the lack of oxygen $(138,139)$. Instead of being beneficial, the elevated arterial oxygen content in the period after asphyxia leads to formation of superoxide radicals and hydrogen peroxide. In the presence of the catalyzing free iron these two compounds react to form the hydroxyl radical. Endogenous CSF contains enough free iron for this process (140). In the brain oxygen derived free radicals are hold responsible for vascular wall damage and cerebral blood flow abnormalities (133). This was confirmed in neonatal lambs, where cerebral hypoperfusion after asphyxia was observed as a result of oxygen derived free radical production (141).

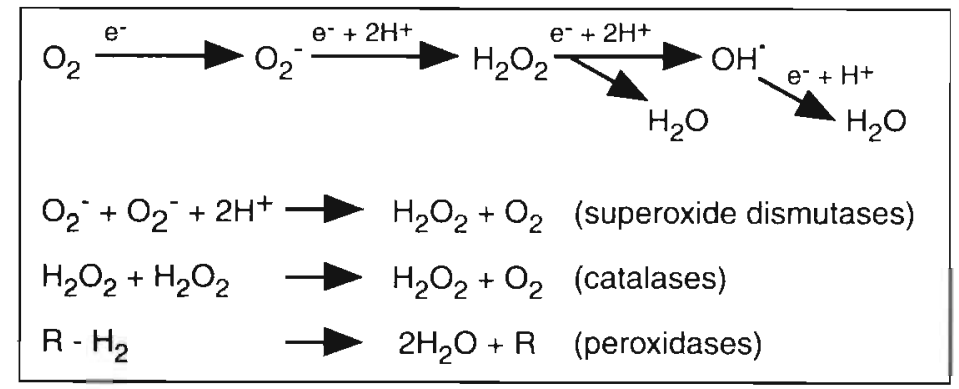

Figure 2.7. Chemical reactions leading to the formation of the hydroxyl radical and the pathways catalyzed by some endogenous oxygen derived free radical scavengers.

\subsection{Calcium}

Lack of oxygen results in energy failure, leading to impeded ATPdependent $\mathrm{Na}^{+} / \mathrm{K}^{+}$-transport. The ensuing decrease in membrane potential opens voltage-dependent calcium channels. Additionally, the decrease of the transmembrane sodium gradient diminishes outward calcium transport. The result is an intracellular influx of calcium, which is considered an important factor in the mechanism of cell death (142). The intracellular calcium concentration is normally maintained near $0.1 \mu \mathrm{M}$, which is 10,000 fold less than the extracellular calcium concentration (143). Overloading of neurons with calcium ions takes place as a result of the rapid break down of the normal calcium gradient across the cell membrane (Figure 2.3). This occurs within a few minutes of complete lack of oxygen, resulting in a 200 -fold increase of intracellular concentrations of free 
calcium $(45,144,145)$. Calcium activates lipases, proteases, and endonucleases: enzymes that degrade the cell structure (146). In the brain, influx of calcium or its release from intracellular stores, could be responsible for the extreme vulnerability of some neuronal populations for oxygen shortage (147). The susceptibility of these cells cannot be ascribed to vascular factors, and it is tempting to assume that these cells are vulnerable because they contain a high density of calcium channels, creating hot spots of calcium accumulation in their dendritic domains. Indeed during hypoxia-ischemia in adult rats, important calcium shifts could be demonstrated cytochemically, mainly at excitatory presynaptic sites. The ion dissipated during the early recovery period (148). There is no doubt that calcium is a co-factor in the activation of xanthine-oxidase and phospholipase. The latter facilitates the production of arachidonic acid out of membrane phospholipids. Part of the complex metabolic and hiochemical events that cause neuronal damage after oxygen shortage are summarized in Figure 2.8.

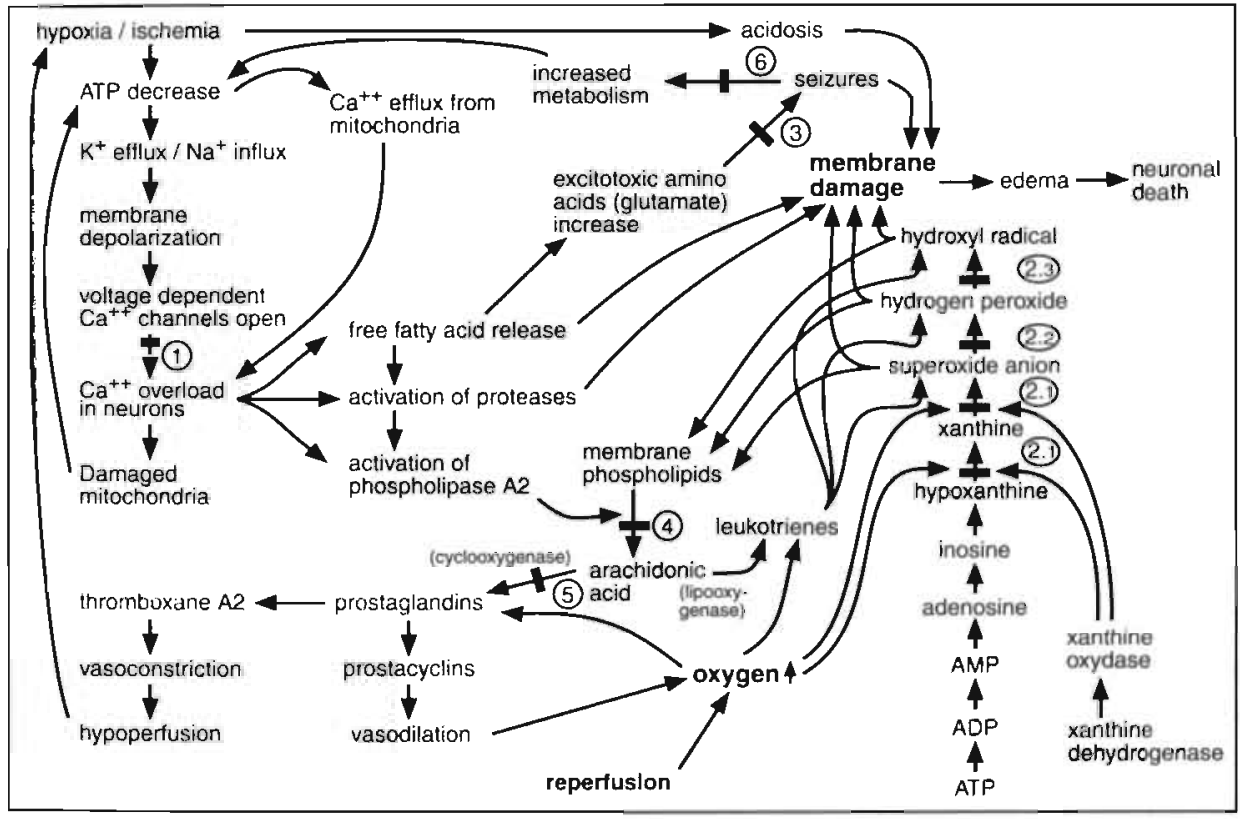

Figure 2.8. Metabolic and biochemical events causing neuronal death due to oxygen shortage, and steps possibly useful to pharmacologic intervention. (1) Calcium channel blockers, (2) Oxygen derived free radical scavengers, (2.1) Allopurinol, (2.2) Superoxide dismutase, (2.3) Catalase, (3) Excitatory amino acid antagonists, (4) Arachidonic acid cascade inhibitors, (5) Indomethacin and other cyclo-oxygenase inhibitors, (6) Seizure suppressants. Reperfusion temporarily aggravates the condition of the nervous system.

Arachidonic acid is the precursor for highly active compounds as thromboxane $A_{2}$ and prostacyclin. These substances have opposite functions: 
vasoconstriction versus vasodilation, platelet aggregation versus inhibition of aggregation. Normally the production of these compounds is adequately balanced. During lack of oxygen however, prostacyclin synthesis is inhibited and thromboxane $\mathrm{A}_{2}$ synthesis increases, stimulating vasoconstriction and platelet aggregation. This vasoconstriction keeps thromboxane $\mathrm{A}_{2}$ locally, but during reoxygenation the resulting vasodilation spreads thromboxane $\mathrm{A}_{2}$ over a larger, and probably healthy, cerebral area (38). This is called the oxygen paradox: reoxygenation aggravates the cerebral condition. Moreover, oxygen results in formation of free radicals due to metabolism of hypoxanthine and xanthine (see ad. 2.5.5). There remains even a third negative impact of oxygen, since during reoxygenation the accumulated arachidonic acid serves as a substrate for two different oxidative enzymatic pathways. The lipo-oxygenase pathway on the one hand metabolizes arachidonic acid to the leukotriene system that effectively contributes to the generation of more oxygen derived free radicals (149). These radicals tend to perpetuate a chain reaction since they accelerate the formation of arachidonic acid via phospholipid degradation and lipid peroxidation. The cyclooxygenase pathway on the other hand contributes to the formation of a host of prostaglandins. The net vascular effect of prostaglandin formation in the brain will be vasoconstriction, since the postasphyxial brain has only a low capacity to synthesize the vasodilator prostacyclin (38), while the production rate of the potent vasoconstrictor thromboxane $\mathrm{A}_{2}$ is high (150). The resulting postischemic hypoperfusion could indeed be prevented by pretreatment with indomethacin, an inhibitor of cyclo-oxygenase activity (151).

\subsubsection{Excitatory neurotransmitters}

Maintaining brain function requires a delicate balance between excitatory and inhibitory neurotransmitter activity. Well-established excitatory neurotransmitters include acetylcholine, dopamine, norepinephrin, and serotonin, whereas inhibitory neurotransmitters include gamma-aminobutyric acid and glycine. More recently the functioning of glutamate has been elucidated (152). Membrane receptors can be activated by glutamate, followed by opening of channels through which ions can pass independent of the electrochemical (voltage) gradient across the plasma membrane (153). Glutamate toxicity is considered a major factor in the production of hypoxic-ischemic injury of selectively vulnerable neurons, i.e., those nerve cells predominantly innervated by glutaminergic neurons (154). The so-called excitotoxic hypothesis of neuronal death (153) implicates that oxygen shortage depolarizes neuronal membranes causing the synaptic discharge of the excitatory neurotransmitter glutamate. Glutamate opens the voltage dependent, $\mathrm{N}$-methyl-D-aspartate specific receptor, allowing calcium to accumulate in the neuron (155). Although experiments are reported in which $\mathrm{N}$ methyl-D-aspartate antagonists reduced brain damage after stroke or hypoglycemic coma, a unifying hypothesis for the role of calcium causing cell 
dysfunction and cell death has not yet been provided (153). Recently however, it is suggested that calcium activates an oxygen dependent neuronal nitric oxide synthetase, which oxidizes arginine to produce nitric oxide when oxygen is readmitted to the cerebrum during reoxygenation. Nitric oxide reacts with the oxygen radical superoxide and powerful cytotoxic oxidants (as, e.g., the hydroxyl radical) are formed (156). This hypothesis is consistent with available evidence on the protective action of $\mathrm{N}$-methyl-D-aspartate blockers in vitro (157) and in vivo (158). Due to its role in the control of cerebral perfusion after oxygen shortage, nitric oxide may elevate the level of oxygen derived free radicals and thus induce part of the secondary neuronal damage (159). Most experiments however were conducted in ischemic conditions, entirely different from intrauterine asphyxia where cerebral blood flow increases until the moment that cardiac output falls. Moreover, it should be noted, that two amino acids that inhibit synaptic transmission are also released. Both gamma-aminobutyric acid and taurin in high concentrations tend to counterbalance the hyperstimulation of postsynaptic neurons induced by the excitatory neurotransmitters, and may therefore play a role in prevention of neuronal damage.

\subsection{Significance of maturity of the fetal brain}

Evidence that the immature animal has a greater tolerance to suffocation than the mature animal was already provided in 1670 . Newborn rat pups were enclosed in a jar with an adult rat and a burning candle. After the candle had expired the young animals survived longer than the adult animal (160). That the immature brain can withstand longer periods of oxygen shortage compared with the mature brain can be explained by differences in structure, differentiation and basal energy demands. The immature brain has smaller and less branched neurones with fewer synapses, and has therefore smaller energy demands than the adult brain $(161,162)$. During oxygen shortage immature rats can preserve cerebral circulation and maintain their energy metabolism for a longer period.

Histological damage after cerebral oxygen shortage is also different in premature infants compared with term infants. Although at microscopic level neuronal or myelin necrosis is the main phenomenon observed, the localization of the lesions varies according to conceptional age at the time of the injury. This appears to be due to a different distribution of blood supply during gestation (163). In preterm infants the main lesion observed is periventricular leukomalacia, often occurring in the white matter region that involves the myelinated fibers descending from the cortical pyramidal cells to innervate mainly the legs, but also the arms and hands (164). Thus, spastic diplegia appears to result of periventricular leukomalacia in premature infants who survive the neonatal period. In children of more than 35 weeks' gestational age, the cortical neurons of the cerebrum, basal ganglia, brainstem, and Purkinje cells of the cerebellum appear to be more vulnerable. The precise reason for this change of susceptibility is not known, 
although for the cerebellum there is a relative lack of blood vessels to the outer layers, containing the Purkinje cells (121).

A final remark concems the plasticity of the brain: although individual neurons may be irreversibly damaged by a previous event, other neurons may recover and take over the function of the dead neuron. This plasticity is demonstrated after antenatal hypoxia in rats: with maturation abnormal behaviour disappears (165).

\subsection{Histologic evaluation of brain damage}

Morphology has the advantage that cellular changes cannot only be visualized and quantified, but also exactly localized. Histology is important in research directed toward the occurrence of damage, in experiments with cerebroprotective drugs, but also postmortem to verify or reject whether asphyxia resulted in brain damage, a matter increasingly important due to medicolegal aspects associated with it.

In chapter 2.6 the distribution of lesions according to the gestational age at the time of asphyxia has been described. Preterm occurring lesions are localized periventricular, whereas at term, the cortex, basal ganglia, brainstem, and Purkinje cells of the cerebellum are affected. Brown and Brierley divided the changes after hypoxia-ischemia into four main categories, which they called in ascending order of severity, microvacuolation, ischemic cell change, severe cell change, and finally cell loss (166). The microvacuoles seen could be identified as severely swollen mitochondria (46). However, it is far from easy to recognize whether the observed empty space is constituted of a swollen neuronal process or a hydropic astrocyte, especially since phagocytosis eliminates damaged cerebral cells. These cells are then replaced by proliferating hematogenous and glial cells and hence do not leave an empty space at all (167). Two types of cerebral cell changes remain dominant and are reproducable to recognize after hypoxia-ischemia: coagulative cell changes, restricted to the neuronal compartment, and edematous cell changes, mainly occurring in the astrocytic compartment (168). The type of change and the extent of damage seems to be determined not only be the original oxygen shortage, but also by factors such as additional acidemia (168), high density of calcium channels $(147,148)$, and the number of glutamate receptors $(148,150)$. Many of the observed changes are fully reversible in conditions of reoxygenation (168). The large variability in models, experimental setups, and methods of morphologic evaluation of tissue, does not facilitate interpretation and comparison of histologic data.

\subsection{Neonatal outcome}

Substantial or prolonged perinatal asphyxia of the full term infant, sufficient to result in permanent neurologic damage, essentially always produces manifestations of neurologic dysfunction during the early days of life. Conversely, 
an intant who does not show neurologic dysfunction in the early nursery period has not suffered from perinatal oxygen shortage severe enough to result in neurological deficits (169,170). The American College of Obstetricians and Gynecologists and the American Academy of Pediatrics have recently defined criteria that must be present when perinatal asphyxia occurs that has the potential for resultant neurologic deficits. All of the following must be present: (I) profound umbilical artery metabolic or mixed acidemia ( $\mathrm{pH}<7.00$ ), (II) persistence of an Apgar score of 0 to 3 for longer than 5 minutes, (III) neonatal neurologic sequelae (e.g., seizures, hypotonia, coma), and (IV) multiorgan system dysfunction (171). The presence of only one of these factors at birth is considered insufficient evidence to substantiate that asphyxia led to the neurologic deficit observed in childhood. This agrees with experimental data (172). Severe asphyxia causes injury to tissues other than the central nervous system: abnormalities of renal function with oliguria or elevated creatine levels, pulmonary hypertension, meconium aspiration, hepatic dysfunction, necrotizing enterocolitis, thrombocytopenia, disseminated intravascular coagulopathy, and even myocardial dysfunction may provide supporting evidence of prior asphyxia and its severity $(173,174)$.

Since cerebral damage accounts for significant morbidity after asphyxia, chapter 2.8 will be limited to the brain. Oxygen shortage sufficient to result in brain dysfunction will produce encephalopathy. The manifestation of this encephalopathy varies with severity and duration of the insult, with degree of development and maturity, and with presence or absence of underlying deficits in brain substrate. Severity of the encephalopathy can clinically be scored according to Sarnat (175) (Table 2.2). Scoring and evolution in days is important because the score has a prognostic value. Newborns with evidence of mild encephalopathy (Sarnat stage 1) had a normal neurologic outcome, $80 \%$ of those with moderate encephalopathy were neurologically normal, and all of the children with severe encephalopathy (Sarnat stage 3) died or had neurologic sequelae (176). This agreed with the original data from Sarnat: infants who did not enter stage 3 and had signs of stage 2 less than 5 days appeared normal in later infancy. Persistance of stage 2 for more than 7 days or failure of the EEG to revert to normal was associated with later neurologic impairment or death (175). In conclusion, the neonatal course appears to give additional evidence of degree and duration of the prior oxygen shortage insult and offers information of prognostic importance $(177,178)$.

Cerebral palsy is a term used to describe a group of diverse nonprogressive syndromes that affect the brain and are associated with impaired motor function. The onset is presumed to be either before or at the time of birth, or in early childhood (179). The most frequently used catagories of cerebral palsy include diplegia (or paraplegia), a form where the legs are primarily atfected; 
Table 2.2. Scoring of encephalopathy according to Sarnat (175)

\begin{tabular}{|c|c|c|c|}
\hline & $\begin{array}{l}\text { stage 1 } \\
\text { mild }\end{array}$ & $\begin{array}{c}\text { stage } 2 \\
\text { moderate }\end{array}$ & $\begin{array}{l}\text { stage } 3 \\
\text { severe }\end{array}$ \\
\hline $\begin{array}{l}\text { Level of } \\
\text { consciousness }\end{array}$ & hyperalert & $\begin{array}{l}\text { lethargic or } \\
\text { obtunded }\end{array}$ & stuporous \\
\hline \multicolumn{4}{|c|}{ Neuromuscular control } \\
\hline - muscle tone & normal & mild hypotonia & flaccid \\
\hline - posture & $\begin{array}{l}\text { mild distal } \\
\text { flexion }\end{array}$ & $\begin{array}{l}\text { strong distal } \\
\text { flexion }\end{array}$ & $\begin{array}{l}\text { intermittent } \\
\text { decerebration }\end{array}$ \\
\hline - strech reflexes & overactive & overactive & decreased or absent \\
\hline - myocionus & present & present & absent \\
\hline \multicolumn{4}{|l|}{ Complex reflexes } \\
\hline - suck & weak & weak or absent & absent \\
\hline - Moro & $\begin{array}{l}\text { strong; low } \\
\text { threshold }\end{array}$ & $\begin{array}{l}\text { weak; incomplete; } \\
\text { high threshold }\end{array}$ & absent \\
\hline - oculovestibular & normal & overactive & weak/absent \\
\hline - Ionic neck & slight & strong & absent \\
\hline Autonomic function & $\begin{array}{l}\text { generalized } \\
\text { sympathetic }\end{array}$ & $\begin{array}{l}\text { generalized } \\
\text { parasympathetic }\end{array}$ & $\begin{array}{l}\text { both systems } \\
\text { depressed }\end{array}$ \\
\hline - pupils & mydriasis & miosis & $\begin{array}{l}\text { variable; } \\
\text { uncqual; poor } \\
\text { light response }\end{array}$ \\
\hline - heart rate & tachycardia & bradycardia & variable \\
\hline $\begin{array}{l}\text { - bronchial and } \\
\text { salivary } \\
\text { secretions }\end{array}$ & sparse & profus: & variable \\
\hline $\begin{array}{l}\text { - gastrointestinal } \\
\text { motility }\end{array}$ & $\begin{array}{l}\text { normal or } \\
\text { decreased }\end{array}$ & $\begin{array}{l}\text { increased, } \\
\text { diarrhea }\end{array}$ & variable \\
\hline Seizures & none & $\begin{array}{l}\text { common; focal } \\
\text { or multifocal }\end{array}$ & $\begin{array}{l}\text { uncommon, } \\
\text { decerebrated }\end{array}$ \\
\hline $\begin{array}{l}\text { Electroencephalo- } \\
\text { gram findings }\end{array}$ & $\begin{array}{l}\text { normal } \\
\text { (awake) }\end{array}$ & $\begin{array}{l}\text { early: low voltage, } \\
\text { delta and theta, } \\
\text { later: periodic } \\
\text { pattern } \\
\text { Seizures: focal } \\
1 \text { to } 1.5 \mathrm{~Hz} \text {, spike } \\
\text { and wave }\end{array}$ & $\begin{array}{l}\text { early: periodic } \\
\text { pattern with } \\
\text { isopotential } \\
\text { phases, later: } \\
\text { totally iso- } \\
\text { potential }\end{array}$ \\
\hline Duration & $<24$ hours & 2 to 14 days & hours to weeks \\
\hline
\end{tabular}

Extrapyramidal (or dyskinetic) types of cerebral palsy include choreoathetosis and ataxia. Cerebral palsy affects 2 in I,000 children in the USA (180). Historically, asphyxia during labor and delivery has been implicated as a major cause of cerebral palsy (181). In the last decade however, a number of large population studies have revealed that asphyxia probably accounts for only a relatively small proportion of cerebral palsy cases. The National Collaborative Perinatal Project studied prospectively the outcome of over 40,000 live births in the USA between 1959 and 1966. From neonates with an Apgar score $\leq 3$ at 5 minutes, more than $95 \%$ did not develop cerebral palsy (182). In a multivariate analysis of 189 
children with cerebral palsy studied up to the age of 7 years, maternal mental retardation, birth weight below $2001 \mathrm{~g}$, and fetal malformations were the leading predictors for cerebral palsy. Breech presentation was also a predictor, but breech delivery was not. The proportion of cerebral palsy that could be attributed to asphyxia was between $3 \%$ and $13 \%$ (183). This is in accordance with the prospective study of more than 43,000 patients undertaken to determine the causes of cerebral palsy, where only $6 \%$ of all cerebral palsy patients had suffered from birth asphyxia (184). Western Australian data support these findings: only in about $8 \%(15 / 183)$ of children cerebral palsy was possibly attributable to intrapartum asphyxia (185). Other reasons for cerebral palsy are trauma, developmental abnormalities, infections (toxoplasmosis, congenital herpes, cytomegalovirus, beta-hemolytic streptococci), radiation, maternal toxemia, intrventricular or subarachnoid hemorrhage and hemolytic disease of the newborn, leading to kemicterus (179). The critical period for development of brain damage underlying cerebral palsy was considered the $26^{\text {th }}$ to $34^{\text {th }}$ week of gestation in particular. This implies that in infants born at term damage occurs during late intrauterine life, while in most preterms damage is established in early neonatal life (186).

In conclusion, most cases of cerebral palsy originate from causes other than asphyxia. Moreover, the majority of even quite severely asphyxiated babies suffer no detectable neurologic or intellectual sequelae. The latter findings are based on epidemiologic observations and suggest that resuscitative efforts in mature newborn infants ought not be too quickly abandoned for fear of late sequelae. Finally, when neurologic symptoms are present, the first days to weeks of life are of prognostic importance.

\subsection{Treatment}

The condition of a neuron after hypoxic-ischemic energy shortage is fragile. The cell membrane is weak and due to activation of catabolic enzymes partly damaged, and mitochondria are suffering from internal elevated calcium levels. Finally, when the enzymes of cellular metabolic pathways denaturate due to elevated calcium concentrations, cell death results. It is impossible to revitalize neurons in which energy providing systems are absent. Therefore, treatment has to be concentrated on the penumbra, the area surrounding the primarily affected area. Neurons in the penumbra are still functioning, but may also get damaged when, during reperfusion or reoxygenation, oxygen derived free radicals, glutamate and thromboxane $A_{2}$ are released. Research on treatment of neuronal damage after oxygen shortage is mainly focused on protection of the penumbra.

In medicine we do not induce asphyxia, but diagnose it. We are not informed about the lag-period between the occurrence of asphyxia and the moment it is diagnosed, or about its severity. Asphyxia long before birth has already led to irreversible damage. Therefore, the window for treatment is 
hampered by unknown variables. Pretreatment of fetuses at risk for asphyxia implicates over-treatment of the normally oxygenated fetuses.

The damaging effect of perinatal asphyxia, recognized at birth, seems to be, at least in part, preventable by various drugs (187). A drug, effective against the damaging action of oxygen lack in the brain has to fulfill at least three important criteria (188): (I) Hemodynamically: the drug should possess antivasoconstrictive activity, without causing systemic vasodilation or impairment of autoregulation. Cardiac depression should be absent, and preferably the drug should be brain vessel selective. (II) Pharmacokinetically: the drug should easily be able to cross the blood-brain barrier and remain bioavailable once penetrated. (III) The drug should increase the tolerance to lack of oxygen, and be effective not only before but, more important, after the period of oxygen shortage.

Possible intervention to reduce neuronal damage after oxygen shortage is indicated in Figure 2.8. Calcium channel blockers. oxygen derived free radical scavengers, anticonvulsants, excitatory neurotransmitter antagonists, neurotrophic growth factors, and gangliosides are discussed in more detail. Most of these drugs meet the criteria to be used against the damaging action of oxygen lack (188).

Calcium channel blockers may limit the influx of calcium into neurons and therefore reduce the amount of primary neuronal death after asphyxia. Flunarizine is a lipid soluble calcium channel blocker that crosses the blood-brain barrier well (189), and has minimal cardiac depression. Rats, pretreated with flunarizine before a hypoxic-ischemic insult, had less brain damage than untreated controls. Detailed histological analysis confirmed that in all cerebral areas significant protection was achieved $(190,191)$. A benefit of the calcium blocker nimodipine was shown in patients with symptomatical clinical cerebral vasospasm or with severe angiographic vasospasm: secondary ischemic brain damage was reduced (192). Not all studies on calcium channel blockers showed beneficial effects: a dramatic decrease of blood pressure and skin perfusion in severely asphyxiated neonates was observed after administration of nicardipine, and therefore continuation of the study was not warranted (193).

Free radical scavengers (194) or drugs that control cerebral edema (195) may have neuroprotective actions, at least in mature animals. Pretreatment of newborn sheep with superoxide dismutase and catalase, enzymes that promote the breakdown of $\mathrm{H}_{2} \mathrm{O}_{2}$ to inactive compounds, prevented the secondary hypoperfusion of the brain following asphyxia (141). The xanthine-oxidase inhibitor allopurinol, administered before hypoxia-ischemia in 7 day old rats showed reduced cerebral edema and reduced histological brain damage (196). Calcium channel blockers and oxygen derived free radical scavengers are considered important in the prevention of primary neuronal damage. Experimental treatment is generally started before the asphyxial event $(141,190,191,196)$, although a combination of oxygen derived free radical scavengers with magnesium administered in 1 week old rat pups during resuscitation after asphyxia also showed protection (197). 
Seizures are regarded as a result of neuronal damage, but moreover, seizures may aggravate cerebral damage. The use of anticonvulsants is proposed to reduce post-insult epileptiform activity and the secondary neuronal death related to this overexcitability of neurons. Treatment may therefore be started after the insult. Intense epileptiform activity leads to spreading depolarization in the neocortex (198), edema, and cell death in vitro (199). In adult rats epileptiform activity for more than 30 minutes can cause rapid neuronal death $(200,201)$, and the onset of postischemic convulsions was closely related with the delayed death of cortical neurons (202). In clinical studies, onset of seizures immediately after asphyxia and prolonged seizures are early predictors of infants who will die or have significant neurologic sequelae $(203,204,205)$. In an effort of postasphyxial therapy barbiturates have not shown consistent benefit either experimentally or in humans $(206,207)$. Classic anticonvulsants (as, e.g., diazepam) are often ineffective in treating seizures after asphyxia in neonates $(208,209)$. The reason for this cuuld be activity of excitatory neurotransmitters $(210)$.

Recently, it has been postulated that cerebral oxygen shortage may interfere with normal neuronal development and thus induce brain damage. Normally suppressed programmed cell death (apoptosis) may be activated. Neuronal hyperexcitability induces a marked rise of neurotrophic factors. These factors appear to be endogenously protective and may play a role in repair/recovery processes after oxygen shortage. Insulin-like growth factors and their binding proteins fibroblast growth factor (211) and calcitonin generated peptide (212) are neurotrophic in vitro (213), in vivo (214), and after asphyxia (215). Administration of these growth factors can improve outcome when given after the insult, showing the importance of trophic factors $(215,216)$. As apoptosis normally occurs in neurons that fail to make connections to trophic support, it is tempting to speculate that additional trophic support, provided by growth factors, may overcome the inappropriate activation of the programmed cell death cascade (217).

Finally, also gangliosides are described in protecting the cerebrum against hypoxic-ischemic injury. Gangliosides are a family of glycosphingolipids that are endogenous components of the plasma membrane. Pretreatment with a monosialoganglioside in near term fetal sheep showed improved recovery of cerebral edema, reduced epileptiform activity, and reduced histological damage after hypoxia-ischemia (218).

In conclusion, cerebral outcome after severe oxygen shortage varies considerably depending on a multitude of known and unknown factors. The diversity of pharmacologic treatment is a reflection of the various pathways leading to neuronal damage. Moreover, this range of different drugs indicates lack of complete insight into pathophysiology as well as ineffectiveness of therapy. 


\subsection{References}

1. Grote J 1980 Gewebsatmung. In: Schmidt RF, Thews G (eds) Physiologie des Menschen (20th ed) Springer Verlag, Berlin, pp 568

2. Guyton AC 199! Textbook of medical physiology (8th ed) Saunders, New York, pp 330-343

3. Sykes GS, Johnson P, Ashworth F, Molloy PM, Gu W, Stirrat GM, Tumbull AC 1982 Do Apgar scores indicate asphyxia? Lancet 1:494-496

4. Gilstrap LC, Leveno KJ, Burris J, Williams ML, Little BB 1989 Diagnosis of birth asphyxia on the basis of fetal $\mathrm{pH}$, Apgar score, and newborn cerebral dysfunction. Am J Obstet Gynecol 161:825-830

5. Low JA 1993 The relationship of asphyxia in the mature fetus to long-term neurologic function. Clin Obstet Gynecol 36:82-90

6. Low JA, Wood SL, Killen HL, Pater EA, Karchmar EJ 1990 Intrapartum asphyxia in the preterm fetus $<2000 \mathrm{~g}$. Am J Obstet Gynecol 162:378-382

7. Cohn HE, Sacks EJ, Heymann MA, Rudolph AM 1974 Cardiovascular responses to hypoxemia and acidemia in fetal lambs. Am J Obstet Gynecol 120:8 17-824

8. Itskovitz J, Goetzman BW, Rudolph AM 1982 The mechanism of late deceleration of the heart rate and its relationship to oxygenation in normoxemic and chronically hypoxemic fetal lambs. Am J Obstet Gynecol 142:66-73

9. Evers JLH, de Haan J, Jongsma HW, Crevels AJ, Arts THM, Martin CB Jr 1981 The preejection period of the fetal cardiac cycle. I. Umbilical cord occlusions. Eur J Obstet Gynecol Reprod Biol 11:401-418

10. Hanson MA 1988 The importance of baro- and chemoreflexes in the control of the fetal cardiovascular system. J Dev Physiol 10:491-511

11. Blanco CE, Dawes GS, Walker DW 1983 Effect of hypoxia on polysynaptic hindlimb reflexes of unanesthetized fetal and newborn lambs. J Physiol 339:453-466

12. Blanco CE, Dawes GS, Hanson MA, McCooke HB 1984 The response to hypoxia of arterial chemoreceptors in fetal sheep and newborn lambs. J Physiol 351:25-37

13. Fivers JLH, de Hain J, Jongsma HW, Crevels AJ, Arts THM, Martin CB Jr 1981 The prejection period of the fetal cardiac cycle. II. Maternal common internal iliac artery occlusion. Eur J Obstet Gynecol Reprod Biol 1 1:419-433

14. Parer JT 1983 The influence of B-adrenergic activity on fetal heart rate and the umbilical circulation during hypoxia in fetal sheep. Am J Obstet Gynecol 147:592597

15. Itskovitz J, LaGamma EF. Rudolph AM 1983 Baroreflex control of the circulation in chronically-instrumented tital lambs. Circ Res 52:589-596

16. Itskovitz J, LaGamma EF, Bristow J, Rudolph AM 1991 Cardiovascular responses to hypoxemia in sinoaortic-denervated fetal sheep. Pediatr Res 30:381-385

17. Rudolph AM 1984 The fetal circulation and its response to stress. J Dev Physiol 6:1119

18. Jones CT, Robinson RO 1975 Plasma catecholamines in foetal and adult sheep. J Physiol 248:15-33 
19. Boddy K, Dawes GS, Fisher R, Pinter S, Robinson JS 1974 Foetal respiratory movements, electrocortical and cardiovascular responses to hypoxaemia and hypercapnia in sheep. J Physiol 243:599-618

20. Jensen A, Berger R 1991 Fetal circulatory responses to oxygen lack. J Dev Physiol 16:181-207

21. Peeters LLH, Sheldon RE, Jones MD, Makowski EL. Meschia G 1979 Blood flow to fetal organs as a function of arterial oxygen content. Am J Obstet Gynecol 135:637646

22. Jensen A, Hohmann M, Künzel W 1987 Dynamic changes in organ blood flow and oxygen consumption during acute asphyxia in fetal sheep. J Dev Physiol 9:543-559

23. Bocking AD, Gagnon R, White SE, Homan J, Milne KM, Richardson BS 1988 Circulatory responses to prolonged hypoxemia in fetal sheep. Am J Obstet Gynecol 159:1418-1424

24. Reuss ML, Rudolph AM 1980 Distribution and recirculation of umbilical and systemic venous blood flow in fetal lambs during hypoxia. J Dev Physiol 2:71-84

25. Dawes GS, Mott JC, Shelley HJ 1959 The importance of cardiac glycogen for the maintenance of life in foetal lambs and new-bom animals during anoxia. J Physiol 146:516-538

26. Mann L 1970 Effects of hypoxia on umbilical circulation and fetal metabolism. Am J Physiol 218:1453-1458

27. Gu W, Jones CT, Parer JT 1985 Metabolic and cardiovascular effects on fetal sheep of sustained reduction of uterine blood flow. J Physiol 368:109-129

28. Saugstad OD 1975 Hypoxanthine as a measurement of hypoxia. Pediatr Res 9:158161

29. Thiringer K, Saugstad OD, Kjellmer I 1980 Plasma hypoxanthine in exteriorized, acutely asphyxiated fetal lambs. Pediatr Res 14:905-910

30. Thiringer K, Blomstrand S. Hrbek A, Karlsson K, Kjellmer I 1982 Cerebral arteriovenous difference for hypoxanthine and lactate during graded asphyxia in the fetal lamb. Brain Res 239:107-117

31. Thiringer K, Karlsson K, Rosen KG, Kjellmer I 1984 Contribution of heart muscle, liver, skeletal muscle and placenta to the asphyxial hypoxanthine elevation in the acutely exteriorized fetal lamb. Biol Neon 45:169-182

32. Gleason CA, Hamm C, Jones MD 1990 Effect of acute hypoxumia on brain blood flow and oxygen metabolism in immature fetal sheep. Am J Physiol 258:H1064H1069

33. Rosenberg AA 1988 Regulation of cerebral blood flow after asphyxia in necunatal lambs. Stroke 19:239-244

34. Hurtado A 1964 Animals in high altitudes. In: Dill DB (ed) Handbook of physiology. Section 4: Adaptation to environment. American Physiological Society, Washington, pp 843-860

35. Brand MM, Bignami A 1969 The effect of chronic hypoxia on the neonatal and infantile brain. Brain 92:233-254 
36. Shapiro HM, Greenberg JH, van Hom Naughton K, Reivich M 1980 Heterogeneity of local cerebral blood flow- PaCO2 sensitivity in neonatal days. J Appl Physiol 49:1 13-118

37. Ashwal S, Dale PS, Longo LD 1984 Regional cerebral blood flow: studies in the fetal lamb during hypoxia, hypercapnia, acidosis, and hypotension. Pediatr Res 18:1309. 1316

38. Raichle ME 1983 The pathophysiology of brain ischemia. Ann Neurol 13:2-10

39. Vannucci RC 1990 Experimental biology of cerebral hypoxia-ischemia: relation to purinatal brain damage. Pediatr Res 27:317-326

40. Siegel GJ, Agranoff BW, Albers RW, Molinoff P (eds) 1989 Basic Neurochemistry (4th ed) Raven Press, New York

41. Yaffe H, Parer JT, Block BS, Llanos AJ 1987 Cardiorespiratory responses to graded reductions of uterine blood flow in the sheep fetus. J Dev Physiol 9:325-336

42. Williams CE, Gunn AJ, Mallard C, Gluckman PD 1992 Outcome after ischemia in the developing sheep brain: an electroencephalographic and histological study. Ann Neurol 31:14-21

43. Silverstein FS, Johnston MV 1984 Effects of hypoxia-ischemia on mono-amine metabolism in the immature brain. Ann Neurol 15:343-347

44. Hansen AJ 1978 The extracellular potassium concentration in brain cortex following ischimia in hypo-and hyperglycemic rats. Acta Physiol Scand 102:324-329

45. Siesjö BK 1981 Cell damage in the brain: a speculative synthesis. J Cereb Blood Flow Metab 1:155-185

46. Brown AW, Brierley JB 1973 The earliest alterations in rat neurons and astrocytes after anoxia-ischemia. Acta Neuropathol 23:9-22

47. Shigeno T, Yamasaki Y, Kato G, Kusaka K, Mima T, Takakura K, Graham DI, Furukiwa S 1990 Reduction of delayed neuronal death by inhibition of protein synthesis. Neurosci Lett 120:117-119

48. Giulian DG, Robertson C 1990 Inhibition of mononuclear phagocytes reduces ischemic injury in the spinal cord. Ann Neurol 27:33-42

49. Hagberg H, Andersson P, Kjellmer I, Thiringer K, Thordstein M 1987 Extracellular overflow of glutamate, aspartate, GABA and taurine in the cortex and basal ganglia of fetal lambs during hypoxia-ischemia. Neurosci Lett 78:311-317

50. Andiné P, Lehmann A, Ellrén K, Wennberg E, Kjellmer I, Nielsen T, Hagberg H 1988 The excitatory aminoacid antagonist kyneuric acid, administered after hypoxiaischemia in neonatal rats offers neuroprotection. Neurosci Lett 90:208-212

51. Lagercrantz H, Bistoletti P 1977 Catecholamine release in the newborn infant at birth. Pediatr Res 11:889-893

52. Nylund L. Lagercrantz H, Lunell NO 1979 Catecholamines in fetal blood during birth in man. J Dev Physiol 1:427-435

53. Jones CT, Ritchie JWK 1983 The eflects of adrenergic blockade on fetal response to hypoxia. J Dev Physiol 5:211-222

54. Dagbjartsson A, Karlsson K, Kjellmer I, Rosen KG 1985 Maternal treatment with a cardioselective beta-blocking agent-consequences for the ovine fetus during 
intermittent asphyxia. J Dev Physiol 7:387-396

55. Challis JRG, Fraher L. Oosterhuis J, White SE, Bocking AD 1989 Fetal and maternal endocrine responses to prolonged reductions in uterine blood flow in pregnant sheep. Am J Obstet Gynecol 160:926-932

56. Jackson BT, Morrison SH, Cohn HE, Piasecki GJ 1989 Adrenal secretion of glucocorticoids during hypoxemia in fetal sheep. Endocrinology 125:2751-2757

57. Wood CE, Chen HG 1989 Acidemia stimulates ACTH, vasopressin, and heart rate responses in fetal sheep. Am J Physiol 257:R344-R349

58. Robillard JE, Weitzman RE, Burmeister L, Smith FG 1981 Developmental aspects of the renal response to hypoxemia in the lamb fetus. Circ Res 48:128-138

59. Rurak DW 1978 Plasma vasopressin levels during hypoxemia and the cardiovascular effects of exogenous vasopressin in foetal and adult sheep. J Physiol 277:341-357

60. Espinoza MI, Riquelme R, Germain AM, Tevah J, Parer JT, Llanos AJ 1989 Role of endogenous opioids in the cardiovascular response to asphyxia in fetal sheep. Am J Physiol 256:R1063-R1068

61. Iversen LL, Iversen SD, Bloom FE 1980 Opiate receptors influence vasopressin release from nerve terminals in rat neurohypophysis. Nature Lond 284:350-351

62. Schadt IC, Gaddis RR 1988 Role of adrenal medulla in hemodynamic response to hemorrhage and naloxone. Am J Physiol 254:R559-R565

63. LaGamma EF, Itskovitz J, Rudolph AM 1982 Effects of naloxone on fetal circulatory responses to hypoxemia. Am J Obstet Gynecol 143:933-940

64. Wilkening RB, Meschia G 1983 Fetal oxygen uptake, oxygenation, and acid-base balance as a function of uterine blood flow. Am J Physiol 244:H749-H755

65. Jones MD, Sheldon RE, Peeters LLH, Meschia G, Battaglia FC, Makowski EL 1977 Fetal cerebral oxygen consumption at different levels of oxygenation. J Appl Physiol 43:1080-1084

66. Fischer DJ, Heymann MA. Rudolph AM 1982 Fetal myocardial oxygen and carbohydrogen consumption during acutely induced hypoxemia. Am J Physiol 242:H657-H66I

67. Parer JT 1980 The effects of acute maternal hypoxia on fetal oxygenation and the umbilical circulation in the sheep. Eur J Obstet Gynecol Reprod Biol 10:125 136

68. Block BS, Schlafer DH, Wentworth RA, Kreitzer LA, Nathanielsz PW 1990 Intrauterine asphyxia and the breakdown of physiologic circulatory compensation in fetal sheep. Am J Obstet Gynecol 162:1325-1331

69. Jennings RB, Steenbergen C Jr 1985 Nucleotide metabolism and cellular damage in myocardial ischemia. Ann Rev Physiol 47:727-749

70. Van Belle H. Goossens F, Wijnants J 1987 formation and release of purine catabolites during hypoperfusion, anoxia, and ischemia. Am J Physiol 252:H886-H893

71. Van Belle H, Wynants J, Xhonneux R, Flameng W 1986 Changes in creatine phosphate, inorganic phosphate, and the purine pattern in dog hearts with time of coronary artery occlusion and effect thereon of mioflazine, a nucleoside transport inhibitor. Cardiovasc Res 20:658-664 
72. Van Belle H 1993 Nucleoside transport inhibition: a therapeutic approach to cardioprotection via adenosine? Cardiovase Res 27:68-76

73. Reimer KA, Jennings RB 1992 Preconditioning. In: Yellon DM, Jennings RB (eds) Myocardial protection: the pathophysiology of reperfusion and reperfusion injury. Raven Press, New York, pp 165-183

74. Liu GS, Thornton J, Van Winkle DM, Stanley AWH, Olsson RA, Downey JM 1991 Protection against infarction afforded by preconditioning is mediated by $\mathrm{Al}$ adenosine receptors in rabbit heart. Circulation $84: 350-356$

75. Pitarys CJ, Virmani R, Vildibill HD, Jackson EK, Forman MB 1991 Reduction of myocardial perfusion injury by intravenous adenosine administered during the early reperfusion period. Circulation 83:237-247

76. Belardinelli L, Linden J, Berne RM 1989 The cardiac effects of adenosine. Prog Cardiovase Dis 32:73-97

77. Hori M, Tamai J, Kitakaze M, Iwakura K, Gotoh K, Iwai K. Koretsune Y, Kagiya T, Kitabake A, Kamada T 1989 Adenosine-induced hyperemia attenuates myocardial ischemia in coronary microembolization in dogs. Am J Physiol 257:H244-H251

78. Schömig A, Richardt G 1990 Cardiac sympathetic activity in myocardial ischemia: release and effects of noradrenaline. Basic Res in Cardiol (Suppl I) 85:9-30

79. Romano FD, Naimi TS, Dobson JG Jr 1991 Adenosine attenuation of catecholamineenhanced contractility in rat heart in vivo. Am J Physiol 260:H1635-H1639

80. Kien M, Belamarich FA, Shepro D 1971 Effect of adenosine and related compounds on thrombocyte and platelet aggregation. Am J Physiol 220:604-608

81. Kitakaze M, Hori M, Sato H, Takashima S, Inoue M, Kitabatake A, Kamada T 1991 Endogenous adenosine inhibits platelet aggregation during myocardial ischemia in dogs. Circ Res 69:1402-1408

82. Mullane KM. Smith CW 1990 The role of leukocytes in ischemic damage, reperfusion injury and repair of the myocardium. In: Piper HM (ed) Pathophysiology of severe ischemic myocardial injury. Kluwer Academic Publishers, Dordrecht, the Netherlands pp 239-267

83. de la Harpe J, Nathan CF 1989 Adenosine regulates the respiratory burst of cytokinetriggered human neutrophils adherent to biologic surfaces. J Immunol 143:596-602

84. Lerman BB, Belardinelli L 1991 Cardiac electrophysiology of adenosine. Basic and clinical concepts. Circulation 83:1499-1509

85. Cremer M 1906 Ueber die direkte Ableitung der Aktionsströme des menschlichen Herzens vom Oesophagus und über das Electrokardiogramm des Fötes. Münchener Med Wochensch 17:811-813

86. Enhöming G, Westin B 1954 Experimental studies of the human fetus in prolonged asphyxia. Acta Physiol Scand 30:359-375

87. Southern EM 1957 Fetal anoxia and its possible relation to changes in the prenatal fetal electrocardiogram. Am J Obstet Gynecol 73:233-247

88. Hon EH, Lee ST 1963 The fetal electrocardiogram. I. The electrocardiogram of the dying fetus. Am J Obstet Gynecol 87:804-813 
89. Larks SD, Larks GG 1965 The electrical axis of the fetal heart: a new criterion for fetal well-being or distress. Am J Obstet Gynecol 93:975-983

90. Lilja H, Arulkumaran S, Lindecrantz K, Ratnam SS, Rosen KG 1988 Fetal ECG during labor: a presentation of a microprocessor system. J Biomed Eng 10:348-350

91. Greene KR, Dawes GS, Lilja H, Rosen KG 1982 Changes in the ST waveform of the fetal lamb electrocardiogram with hypoxemia. Am J Obstet Gynecol 144:950-958

92. Rosen KG, Dagbjartsson A, Henriksson BA, Lagercrantz H, Kjellmer I 1984 The relationship between circulating catecholamines and ST waveform in the fetal lamb electrocardiogram during hypoxia. Am J Obstet Gynecol 149:190-195

93. Widmark C, Hökegård KH, Lagercrantz H, Lilja H, Rosen KG 1989 Electrocardiographic waveform changes and catecholamine responses during acute hypoxia in the immature and mature fetal lamb. Am J Obstet Gynecol 160:1245-1250

94. Low JA, Galbraith RS, Muir DW, Killen HL, Pater EA, Karchmar EJ 1988 Motor and cognitive deficits after intrapartum asphyxia in the mature fetus. Am J Cbstet Gynecol 158:356-361

95. Goodwin TM, Belai I, Hernandez P, Durand M, Paul RH 1992 Asphyxial complications in the term newborn with severe umbilical acidemia. Am J Obstet Gynecol 167:1506-1512

96. Newbold S, Wheeler T, Clewlow F 1991 Comparison of the T/QRS ratio of the fetal electrocardiogram and the fetal heart rate during labour and the relation of these variables to condition at delivery. Br J Obstet Gynaecol 98:173-178

97. McLachlan NA, Spencer JAD, Harding K, Arulkumaran S 1992 Fetal acidaemia, the cardiotocograph and the T/QRS ratio of the fetal ECG in labour. Br J Obstet Gynaccol 99:26-31

98. Murphy KW, Russell V, Johnson P, Valente J 1992 Clinical assessment of fetal electrocardiogram monitoring in labour. Br J Obstet Gynaecol 99:32-37

99. Westgate J, Harris M, Curnow JSH, Greene KR 1992 Randomised trial of cardiotocography alone or with ST waveform analysis for intrapartum monitoring. Lancet 340:194-198

100. Westgate J, Harris M, Curnow JSH, Greene KR 1993 Plymouth randomized trial of cardiotocogram only versus ST waveform plus cardiotocogram for intrapartum monitoring in 2400 cases. Am J Obstet Gynecol 169:1 151-1160

101. Haverkamp AD, Orleans M, Langendörfer S, McFee J, Murphy J, Thompson H 1979 A controlled trial of the differential effects of intrapartum fetal monitoring. Am J Obstet Gynecol 134:399-408

102. MacDonald D, Grant A, Sheridan-Pereira M, Boylan P, Chalmers I 1985 The Dublin randomized controlled trial of intrapartum fetal heart rate monitoring. Am J Obstet Gynecol 152:524-539

103. Leveno KJ, Cunningham FG, Nelson S, Roark M, Williams ML, Guzick D, Dowling S, Rosenfeld CR, Buckley A 1986 A prospective comparison of selective and universal electronic fetal monitoring in 34,995 pregnancies. N Engl J Med 315:615619 
104. Hrbek A, Karlsson K, Kjellmer I, Olsson T, Riha M 1974 Cerebral reactions during intrauterine asphyxia in the sheep. II. Evoked electroencephalogram responses. Pediatr Res 8:58-63

105. Mann LI, Solomon G, Carmichael A, Duchin S 1971 The effect of metabolic acidosis on fetal brain function and metabolism. Am J Obstet Gynecol 111:353-359

106. Myers RE. Yamaguchi M 1976 Effect of serum glucose concentrations on brain response to circulatory arrest. J Neuropath Exp Neur 35:301

107. de Courten-Myers GM, Kleinholz M, Wagner KR, Myers RE 1989 Fatal stroke in hyperglycemic cats. Stroke 20:1707-1715

108. Wagner KR, Kleinholz M, Myers RE 1989 Delayed neurologic deterioration following anoxia: brain mitochondrial and metabolic correlates. J Neurochem 52:1407-1417

109. Rehncona S, Rosen I, Siesjö BK 1981 Brain lactic acidosis and ischemic cell damage. I. Biochemistry and neurophysiology. J Cereb Blood Flow Metab 1:297-311

110. Longstreth WT Jr, Diehr P, Inui TS 1983 Prediction of awakening after out-ofhospital cardiac arrest. N Engl J Med 308:1378-1382

111. Cunningham FG, McDonald OC, Gant NF (eds) 1989 Williams Obstetrics (18th ed) Appleton \& Lange, East Norwalk, pp 816-819

112. Sack RA 1969 The large infant: a study of maternal, obstetric and newborn characteristics; including a long-term pediatric follow-up. Am J Obstet Gynecol 104:195-204

113. Villar J, de Onis M, Kestler E, Bolaños F, Cerezo R, Bernedez H 1990 The differential neonatal morbidity of the intrauterine growth retardation syndrome. Am J Obstet Gynecol 163:151-157

1 14. Thordstein M, Kjellmer 11988 Cerebral tolerance of hypoxia in growth-retarded and appropriately grown newborn guinea pigs. Pediatr Res 24:633-638

115. Walter FJ, Ramaekers LHJ 1982 The Ponderal index as a measure of the nutritional status at birth and its relation to some aspects of neonatal morbidity. J Perinat Med 10:42-47

116. Guyton AC 1991 Textbook of medical physiology (8th ed) Saunders, New York, pp $185-190$

117. Papile LA, Rudolph AM. Heymann MA 1985 Autoregulation of cerebral blood flow in the preterm fetal lamb. Pediatr Res 19:159-161

118. Ting P, Yamaguchi S, Barcher JD, Killens RH, Myers RE 1983 Hypoxic-ischemic cercbral necrosis in midgestational sheep fetuses: physiopathologic correlations. Exp Neurol 80:227-245

1 19. Gunn AJ, Parer JT, Mallard EC, Williams CE, Gluckman PD 1992 Cerebral histologic and electrocorticographic changes after asphyxia in fetal sheep. Pediatr Res 31:486491

120. de Courten-Myers GM, Yamaguchi S, Wagner KR, Ting P. Myers RE 1985 Brain injury lrom marked hypoxia in cats: role of hypotension and hyperglycemia. Stroke 10:1016-1021 
121. Koenigsberger MR 1991 Acute encephalopathies of infancy. In: Rudolph AM (ed) Rudolph's Pediatrics (19th ed) Appleton \& Lange, Norwalk, pp 1705-1713

122. Reynolds ML, Evans CAN, Reynolds EOR, Saunders NR, Durbin GM, Wigglesworth JS 1979 Intracranial hemorrhage in the preterm sheep fetus. Early Hum Dev 3:163186

123. Schuier F, Hossmann KA 1980 Experimental brain infarcts in cats. II. Ischemic brain edema. Stroke 11:593-601

124. Williams CE, Mallard EC, Tan WKM, Gluckman PD 1993 Pathophysiology of perinatal asphyxia. Clin Perinat 20:305-325

125. Cole DJ, Matsumura JS, Drummond JC 1992 Focal cerebral ischemia in rats: Effects of induced hypertension, during reperfusion, on CBF. J Cereb Blood Flow Metab 12:64-69

126. Longo LD, Pearce WJ 1991 Fetal and newborn cerebral vascular responses and adaptations to hypoxia. Sem Perinat 15:49-57

127. Jones MD, 'Traystman RJ 1984 Cerebral oxygenation of the fetus, newborn, and adult. Sem Perinat 8:205-216

128. Levine S 1960 Anoxic-ischemic encephalopathy in rats. Am J Pathol 36:1-17

129. Williams CE, Gunn AJ, Synek B, Gluckman PD 1990 Delayed seizures occurring with hypoxic-ischemic encephalopathy in the fetal sheep. Pediatr Res 27:561-565

130. Lupton BA, Hill A, Roland EH, Whitfield MF, Flodmark O 1988 Brain swelling in the asphyxiated term newborn: pathogenesis and outcome. Pediatrics 82:139-146

131. Del Maestro RF. Thaw HH. Björk J. Planker M, Arfors KE 1980 Free radicals as mediators of tissue injury. Acta Physiol Scand (Suppl) 492:43-57

132. Haber F, Weiss J 1934 The catalytic decomposition of hydrogen peroxide by iron salts. Proceedings of the Royal Society, London A147:332-351

133. Kontos HA 1985 Oxygen radicals in cerebral vascular injury. Circ Res 57:508-516

134. Ljunggren B, Schultz H, Siesjö BK 1974 Changes in energy state and acid-base parameters of the rat brain during complete compression ischemia. Brain Res 73:277289

135. Thomas MJ, Mehl KS, Pryor WA 1978 The role of the superoxide anion in the xanthine oxidase induced autooxidation of linoleic acid. Biochem Biophys Res Comm 83:927-932

136. Saugstad OD 1988 Hypoxanthine as an indicator of hypoxia: its role in health and disease through free radical production. Pediatr Res 23:143-150

137. Betz AL 1985 Identification of hypoxanthine transport and xanthine-oxidase activity in brain capillaries. J Neurochem 4:574-579

138. Parks DA. Bulkley GB, Granger N, Hamilton SR. McCord JM 1982 Ischaemic injury to the cat small intestine: role of superoxide radicals. Gastroenterology 82:9-15

139. McCord JM 1985 Oxygen-derived free radicals in post-ischemic injury. New Engl J Med 312:159-163

140. Halliwell B, Gutteridge JMC 1984 Oxygen toxicity, oxygen radicals, transition metals and disease. Biochem J 219:1-14 
141. Rosenberg AA, Murdaugh E, White CW 1989 The role of oxygen free radicals in postasphyxia cerebral hypoperfusion in newborn lambs. Pediatr Res 26:215-219

142. Farber JL 1981 The role of calcium in cell death. Life Sci 29:1289-1295

143. Katz AM, Reuter H 1979 Cellular calcium and cardiac cell death. Am J Cardiol 44: $188-190$

144. Vykocil F, Kritz N, Bures J 1972 Potassium selective microelectrodes used for measuring the extracellular brain $\mathrm{K}+$ during spreading depression and anoxic depolarization in rats. Brain Res 39:255-259

145. White BC. Winegar CD, Wilson RF, Krause GS 1983 Calcium blockers in cerebral resuscitation. J of Trauma 23:788-793

146. Siesjö BK, Wieloch T 1985 Cerebral metabolism in ischemia: neurochemical basis for therapy. Br J Anaesth 57:47-62

147. Smith ML, Auer RN, Siesjö BK 1984 The density and distribution of ischemic brain injury in the rat following two to ten minutes of forebrain ischemia. Acta Neuropathol (Berl) 64:319-332

148. Van Reempts J, Borgers M 1985 Ischemic brain injury and cell calcium: morphologic and therapeutic aspects. Ann Emerg Med 14:736-742

149. Chan PH, Fishman RA 1978 Transient formation of superoxide radicals in polyunsaturated fatty acid induced brain swelling. J of Neurochem 35:1004-1007

150. Gaudet RJ, Levine L 1979 Transient cerebral ischemia and brain prostaglandines. Biochem Biophys Res Com 86:893-901

151. Hallenbeck JM, Furlow TW 1979 Prostaglandin 12 and indomethacin prevent impairment of post-ischemic brain reperfusion in the dog. Stroke 10:629-637

152. Kjellmer I 199 I Mechanisms of perinatal brain damage. Ann Med 23:675-679

153. Siesjö BK, Bengtsson F 1989 Calcium fluxes, calcium antagonists, and calciumrelated pathology in brain ischemia, hypoglycemia, and spreading depression: a unifying hypothesis. J Cereb Blood Flow Metab 9:127-140

154. Jörgensen MB, Diemer NH 1982 Selective neuron loss after cerebral ischemia in the rat: possible role of transmitter glutamate. Acta Neurol Scand 66:536-546

155.Fagg GE 1985 L-glutamate, excitatory amino acid receptors and hrain functions. Trends Neurosci 8:207-210

156. Beckman JS 1991 The double-edged role of nitric oxide in brain function and superoxide-mediated injury. J Dev Physiol 15:53-59

157. Rothman S 1984 Synaptic release of excitatory aminoacid neurotransmitter mediates anoxic neuronal death. J Neurosci 4:1884-1891

158. Simon RP, Swan JH, Griffiths T, Meldrum BS 1984 Blockade of N-methyl-Daspartate receptors may protect against ischemic damage in the brain. Science 226:850-852

159. Iwamoto J, Yoshinaga M, Yang S, Krasney E, Krasney J 1992 Methylene blue inhibits hypoxic cerebral vasodilation in awake sheep. J Appl Physiol 73:2226-2232

160. Boyle R 1670 New pneumatical experiments about respiration. Philosophical transactions of the Royal Society, London 62:201 I-203 I 
161. Duffy TE, Kohle SJ, Vannucci RC 1975 Carbohydrate and energy metabolism in perinatal rat brain: relation to survival in anoxia. J Neurochem 24:271-276

162. Hansen AJ 1985 Effect of anoxia on ion distribution in the brain. Physiol Rev 65:101148

163. De Reuck J, Chatta AS, Richardson EP 1972 Pathogenesis and evolution of periventricular leukomalacia in infancy. Arch Neurol 27:229-236

164. Levene MI, Wigglesworth JS, Dubowitz V 1983 Hemorrhagic periventricular leukomalacia in the neonate: a real-time ultrasound study. Pediatrics 71:794-797

165. Hermans RHM, Hunter DE, McGivem RF, Cain CD, Longo LD 1992 Behavioural sequelae in young rats of acute intermittent antenatal hypoxia. Neurotoxicology Teratology 14:119-129

166. Brown AW, Brierley JB 1968 The nature, distribution and earliest stages of anoxicischemic nerve cell damage in the rat brain as defined by the optical microscope. $\mathrm{Br} \mathrm{J}$ Exp Pathol 49:87-106

167. Van Reempts J, Borgers M 1990 Structural damage in experimental cerebral ischemia. In: Schurr A, Rigor BM (eds) Cerebral ischemia and resuscitation. CRC Press, Boca Raton, pp 235-257

168. Van Reempts J 1984 The hypoxic brain: histological and ultrastructural aspects. Behav Brain Res 14:99-108

169. Nelson KB, Ellenberg JH 1987 The asymptomatic newborn and risk of cerebral palsy. Am J Dis Child 141:1333-1335

170. Volpe JJ 1987 Neurology of the newborn (2nd ed) WB Saunders, Philadelphia

171. American Academy of Pediatrics, American College of Obstetricians and Gynecologists 1992 Relationship between perinatal factors and neurologic outcome. In: Poland RL, Freeman RK (eds) Guidelines for perinatal care (3rd ed) Elk Grove Village. Illinois, pp 221-224

172. Freeman JM, Nelson KB 1988 Intrapartum asphyxia and cerebral palsy. Pediatrics 82:240-249

173. Sexon WR, Sexon SB, Rawson JE, Brann AW 1976 The multisystem involvement of the asphyxiated newborn. Pediatr Res 10:432

174. Carter BS, Haverkamp AD, Merenstein GB 1993 The definition of acute perinatal asphyxia. Clin Perinat 20:287-304

175. Sarnat HB, Sarnat MS 1976 Neonatal encephalopathy following fetal distress: A clinical and electroencephalographic study. Arch Neurol 33:696-705

176. Robertson C, Finer N 1985 Term infants with hypoxic-ischemic encephalopathy: outcome at 3.5 years. Dev Med Child Neurol 27:473-484

177. Nelson KB, Ellenberg JH 1981 Apgar scores as predictors of chronic neurologic disability. Pediatrics 68:36-44

178. Levene MI, Sands C, Grindulis H, Moore JR 1986 Comparison of two methods of predicting outcome in perinatal asphyxia. Lancet 1:67-68

179. Wollack JB, Low NL, Carter S 1991 Static encephalopathies. In: Rudolph AM (ed) Rudolph's Pediatrics (19th ed) Appleton \& Lange, Norwalk, pp 1720-1724 
180. Kudrjavcev T, Schoenberg BS, Kurland LT, Groover RN 1983 Cerebral palsy- trends in incidence and changes in concurrent neonatal mortality: Rochester MN, 1959-1976. Neurology 33:1433-1438

181. Little WJ 1862 On the influence of abnormal parturition, difficult labour, premature birth and asphyxia neonatorum on mental and physical conditions of the child, especially in relation to deformities. Trans Obstet Soc Lond 3:293-344

182. Paneth N, Stark IS 1983 Cerebral palsy and mental retardation in relation to indicators of perinatal asphyxia. Am J Obstet Gynecol 147:960-966

183. Nelson KB, Ellenberg JH 1986 Antecedents of cerebral palsy-multivariate analysis of risk. N Engl J Med 315:81-86

184. Naeye RL, Peters EC, Bartholomew M, Landis JR 1989 Origins of cerebral palsy. A.JDC 143:1154-1161

185. Blair E. Stanley F 1988 Intrapartum asphyxia: a rare cause of cerebral palsy. J Pediatr $1 \mid 2: 515-519$

186. Hagberg B, Hagberg G, Olow I 1982 Gains and hazards of intensive neonatal care: an analysis from Swedish cerebral palsy epidemiology. Dev Med Child Neurol 24:13-19

187. Espinoza MI, Parer JT 1991 Mechanisms of asphyxial brain damage, and possible pharmacologic interventions, in the fetus. Am J Obstet Gynecol 164:1582-1591

188. Borgers M, Van Reempts J 1989 Effect of Ca2+ entry blockers on ischemic brain. J Neurosurg Anesthesiol 4:368-374

189. Holmes B, Brogden R, Heel R, Speight T, Avery G 1984 Flunarizine: a review of its pharmacological and pharmacokinetic properties and therapeutic use. Drugs 27:6-44

190. Silverstein FS. Buchanan K, Hudson C, Johnston MV 1986 Flunarizine limits hypoxic-ischemia induced morphologic injury in immature rat brain. Stroke 17:477-482

191. Gunn AJ, Mydlar T, Bennet L, Faull RLM, Gorter S, Cook C, Johnston BM 1989 The neuroprotective actions of a calcium channel antagonist, flunarizine, in the infant rat. Pediatr Res 25:573-576

192. Jan M, Buckheit F, Tremoulet M 1988 Therapeutic trial of intravenous nimodipine in patients with established cerebral vasospasm after rupture of intracranial aneurysms. Neurosurgery 23:154-157

193. Levene MI, Gibson NA. Fenton AC, Papathoma E, Barnett D 1990 The use of a calcium-channel blocker, nicardipine, for severely asphyxiated newborm infants. Dev Med Child Neurol 32:567-574

194. Abe K, Yuki S, Kogure K 1988 Strong attenuation of ischemic and post-ischemic brain edema in rats by a novel free radical scavenger. Stroke 19:480-485

195. Sutherland G. Lesiuk H. Bose R, Sima A 1988 Effect of mannitol. nimodipine and endomethacin singly or in combination on cerebral ischemia in rats. Stroke 19:571-578

196. Palmer C, Vannucci RC, Towfighi J 1990 Reduction of perinatal hypoxic-ischemic brain damage with allopurinol. Pediatr Res 27:332-336

197. Thordstein M, Băgenholm R, Thiringer K, Kjellmer I 1993 Scavengers of free oxygen radicals in combination with magnesium ameliorate perinatal hypoxic-ischemic brain damage in the rat. Pediatr Res 34:23-26 
198. Hablitz J, Heinemann U 1989 Alterations in the micro-environment during spreading depression associated with epileptiform activity in the immature cortex. Dev Brain Res 46:243-252

199. Watson G. Rader R, Lanthorn T 1989 Epileptiform activity in vitro can produce longterm synaptic failure and persistent neuronal depolarization. Brain Res 498:81-88

200. Nevander G, Ingvar M, Auer R, Siesjö BK 1985 Status epilepticus in well-oxygenated rats causes neuronal necrosis. Ann Neurol 18:281-290

201. Ingvar M, Morgan P, Auer R 1988 The nature and timing of excitotoxic neuronal necrosis in the cerebral cortex, hippocampus and thalamus due to fluoroethyl-induced status epilepticus. Acta Neuropath 75:362-369

202. Smith M, Kalimo H, Wamer D, Siesjö BK 1988 Morphological lesions in the brain preceding the development of post-ischemic seizures. Acta Neuropath 76:253-264

203. Mellitz E, Holden K, Freeman J 1982 Neonatal seizures II. A multivariate analysis of factors associated with outcome. Pediatrics 70:177-185

204. Tudehope D, Harris A, Hawes D, Hayes M 1988 Clinical spectrum and outcome of neonatal convulsions. Aust Paediatr J 24:249-253

205. Watkins A, Szymonowicz W, Jin X, Yu VWY 1988 Significance of seizures in very low-birth weight infants. Dev Med Child Neurol 30:162-169

206. Goldberg R, Moscosos P, Bloom F, Curless R, Burke B, Bancalari F 1986 Use of barbiturate therapy in severe perinatal asphyxia: a randomized controlled trial. J Pediatr 109: 851-856

207. Trauner D 1986 Barbiturate therapy in acute brain injury. J Pediatr 109:742-746

208. Eyre J, Wilkinson A 1986 Thiopentone induced coma after severc birth asphyxia. Arch Dis Child 61:1084-1089

209. Connell J, Oozeer R, de Vries L, Dubowitz L, Dubowitz V 1989 Clinical and EFG response to anticonvulsants in neonatal seizures. Arch Dis Child 64:459-464

210. Williams CE, Gluckman PD, Gunn AJ, Tan WK, Dragunow M 1990 Perinatal asphyxic brain damage- the potential for therapeutic intervention. In: Dawes GS, Zacutti A, Borruto F, Zacutti A Jr (eds) Fetal autonomy and adaptation, John Wiley \& sons, Chichester, New York, pp 145-163

211. Finklestein SP, Caday CG, Kano M, Berlove DJ, Hsu CY, Moskowitz M, Klagbrun M 1990 Growth factor expression after stroke. Stroke 21 (Suppl 3):122-124

212. Dragunow M, Sirimanne E, Lawlor PA, Williams CE, Leah J, Gluckman PD 1992 A role for calcitonin-gene-related peptide during recovery from hypoxic-ischaemic brain injury in the infant rat. Brain Res 114:267-272

213. Knusel M, Michel PP, Schwaber JS, Hefti F 1990 Selective and nonselective stimulation of cerebral cholinergic and dopaminergic development in vitro by nerve growth factor, basic fibroblast growth factor, epidermal growth factor insulin and the insulin-like growth factors 1 and 2. J Neurosci 10:558-570

214. Kanje M, Skottner A, Sjöberg J, Lundberg G 1989 Insulin-like growth factor 1 (IGF1) stimulates regeneration of the rat schiatic nerve. Brain Res 489:396-398 
215. Gluckman PD, Klempt ND, Guan J, Mallard EC, Sirimanne E, Dragunow M, Singh K. Klempt M, Williams CE, Nicolics K 1992 A role for IGF-1 in the rescue of CNS neurons following hypoxic-ischemic injury. Biochem Biophys Res Comm 182:593599

216. Yamada K, Kinoshita A, Kohmura E, Sakaguchi T, Taguchi J, Kataoka K, Hayakawa T 1991 Basic fibroblast growth factor prevents thalamic degeneration after cortical infarction. J Cereb Blood Flow Metab 11:472-478

217. Gluckman PD, Williams CE 1992 When and why do brain cells die? Dev Med Child Neurol 34:1010-1014

218. Tan WKM, Williams CE, Gunn AJ, Mallard EC, Gluckman PD 1993 Pretreatment with monosialoganglioside GM1 protects the brain of fetal sheep against hypoxicischemic injury without causing systemic compromise. Pediatr Res 34:18-22 


\section{Chapter 3}

\section{Material and methods}

\subsection{Surgery \\ 3.2. Measurements \\ 3.3. Experiments}

3.4. Fixation procedure and histologic evaluation

3.5. Calculations and data analysis

3.6. Statistics

3.7. References 


\subsection{Surgery}

Surgery was performed in 47 Dutch Texel sheep of known mating dates between 110 and 128 days gestation (mean $\pm \mathrm{SD}=120.0 \pm 2.8$ days, term $=147$ days).

General anesthesia was induced with intravenous pentobarbital and maintained with $1 \%$ halothane in a 2:1 mixture of nitrous oxide and oxygen. Ewes were placed in left tilted Trendelenburg position to avoid compression on the inferior vena cava and the associated uterine hypoperfusion. Legs were fastened upon the operating table. Before surgery ewes received intravenous $1 \mathrm{~g}$ of ampicillin. Abdomen and left flank of the ewe were shaved, cleaned, and twice rinsed with an iodine solution. The ewe was covered with sterile drapes except for the lower abdomen in the midline.

Under sterile conditions, a paramedian abdominal incision was made. The uterus was lifted out of the pelvis for a maximum period of 3 minutes, since this maneuver interferes with uterine circulation. The distal aorta of the ewe ends in a trifurcation: the external iliac arteries provide mainly hindlimbs, genitals, and udders with blood and the common internal iliac artery, which divides in two

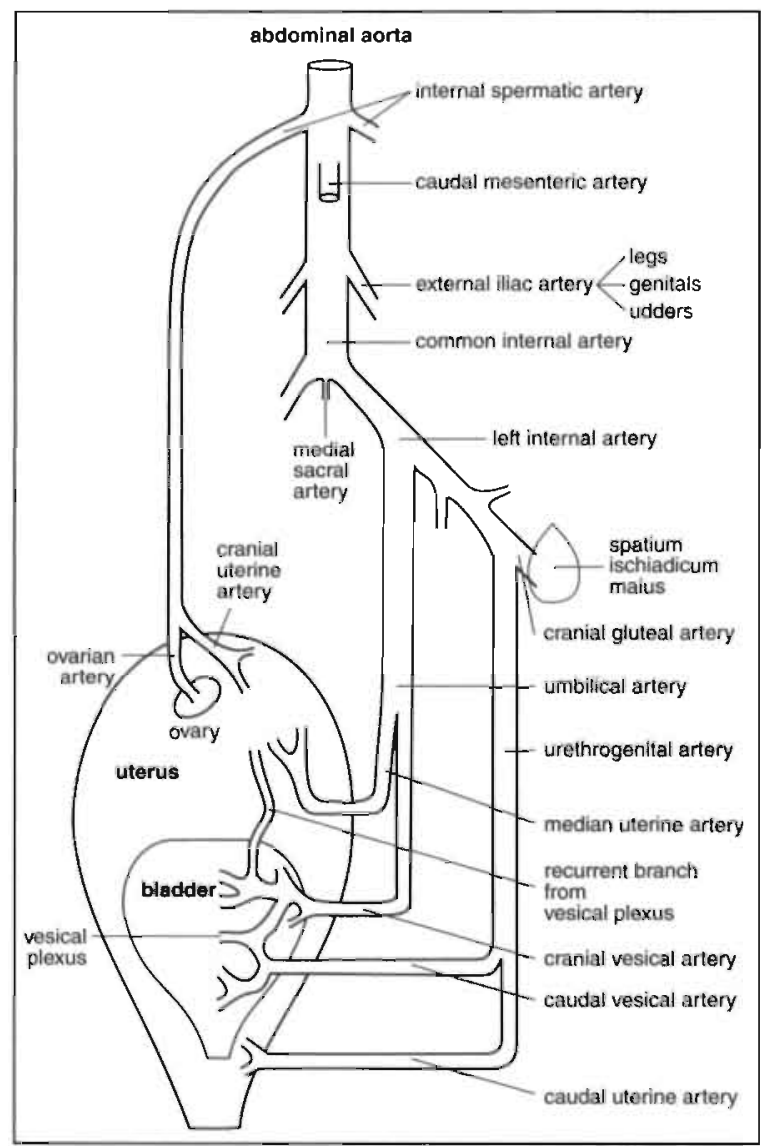

branches (usually 0.5 to 3.0 $\mathrm{cm}$ distal from the trifurcation) and supplies mainly both uterine horns. The vascularization pattern of the main pelvic organs is summarized in Figure 3.1.

Figure 3.1. Vascularization pattern of the main pelvic organs in Dutch Texel sheep. Reproduced with permission (1). 
The retroperitoneal space over the trifurcation of the aorta was opened and the vessels were exposed by sharp and blunt dissection. An inflatable balloon occluder was placed around the maternal common internal iliac artery and secured with a linen tie. If the occluder could not be placed within the maximum period of 3 minutes, this procedure was repeated after 3 to 5 minutes. In contrast to primates, sheep have thin uterine musculature and a cotyledonous placenta. The uterus was incised in an area free of cotyledons. The incisional site was chosen to be able to extract at first the cranial part and afterwards the caudal end of the fetus, through the same aperture. Polyvinyl catheters used had an outer diameter of 1.6 $\mathrm{mm}$ and an inner diameter of $0.8 \mathrm{~mm}$ (Talas B.V., Ommen, the Netherlands). Fetal instrumentation involved:

- insertion of a polyvinyl catheter in the axillary artery, the tip advanced to the level of the brachiocephalic trunk.

- placement of isolated fine multistranded stainless-steel wires (AS 632, Cooner Sales (o., Chatsworth, California, USA) over the dura of the parietal cortex through burr holes $1 \mathrm{~cm}$ lateral from the midline and a reference electrode fixed subcutaneously in the midline between both parietal electrodes, for recording of the fetal electrocorticogram $(E C o G)$.

- placement of a polyvinyl catheter in the spinal cavity to obtain CSF. A midline incision was made in the dorsal surface of the fital neck, and the epidural cavity was opened (2). Epidural fat, containing small veins, was carefully swept away with a cotton-tipped applicator and the spinal cavity was opened with a needle. The catheter was inserted through the puncture hole into the spinal cavity and advanced 1.0 to $2.0 \mathrm{~cm}$ cranially until adequate CSF sampling was possible. The catheter was fixed with tissue glue and sutured to the fetal skin. Its tip was located in the spinal cistern. CSF that appeared after opening of the spinal cavity was sampled with a $1 \mathrm{~mL}$ syringe.

- placement of electrodes, made of stranded silver plated copper wire isolated with extruded Teflon, subcutaneously at the level of the cardiac apex and at the upper part of both forelegs for recording of the fetal ECG.

- insertion of a polyvinyl catheter in the femoral artery, the tip advanced to the level of the descending aorta.

- insertion of a polyvinyl catheter in the femoral vein with the tip advanced into the inferior vena cava.

- insertion of a polyvinyl catheter in the trachea.

- insertion of a polyvinyl catheter in the amniotic cavity.

After fetal instrumentation lost amniotic fluid was replaced by warm

$\left(39^{\circ} \mathrm{C}\right)$ saline and the uterus was closed in two layers. Catheters and wires were exteriorized through a small incision in the ewe's flank. A small pouch attached to the ewe's flank protected catheters and electrodes during the recovery period. Finally, the abdominal wall of the ewe was closed. 
After surgery ewes were housed in individual cages with free access to food and water (Figure 3.2) and were allowed to recover for at least 3 days before experiments were started. A continuous slow infusion ( $1 \mathrm{~mL} /$ hour) of heparin in saline $(10 \mathrm{U} / \mathrm{mL})$ was used to maintain patency of fetal arterial and venous catheters. Guidelines for care and use of animals as approved by the local Animal Medical Ethics Committee were followed.

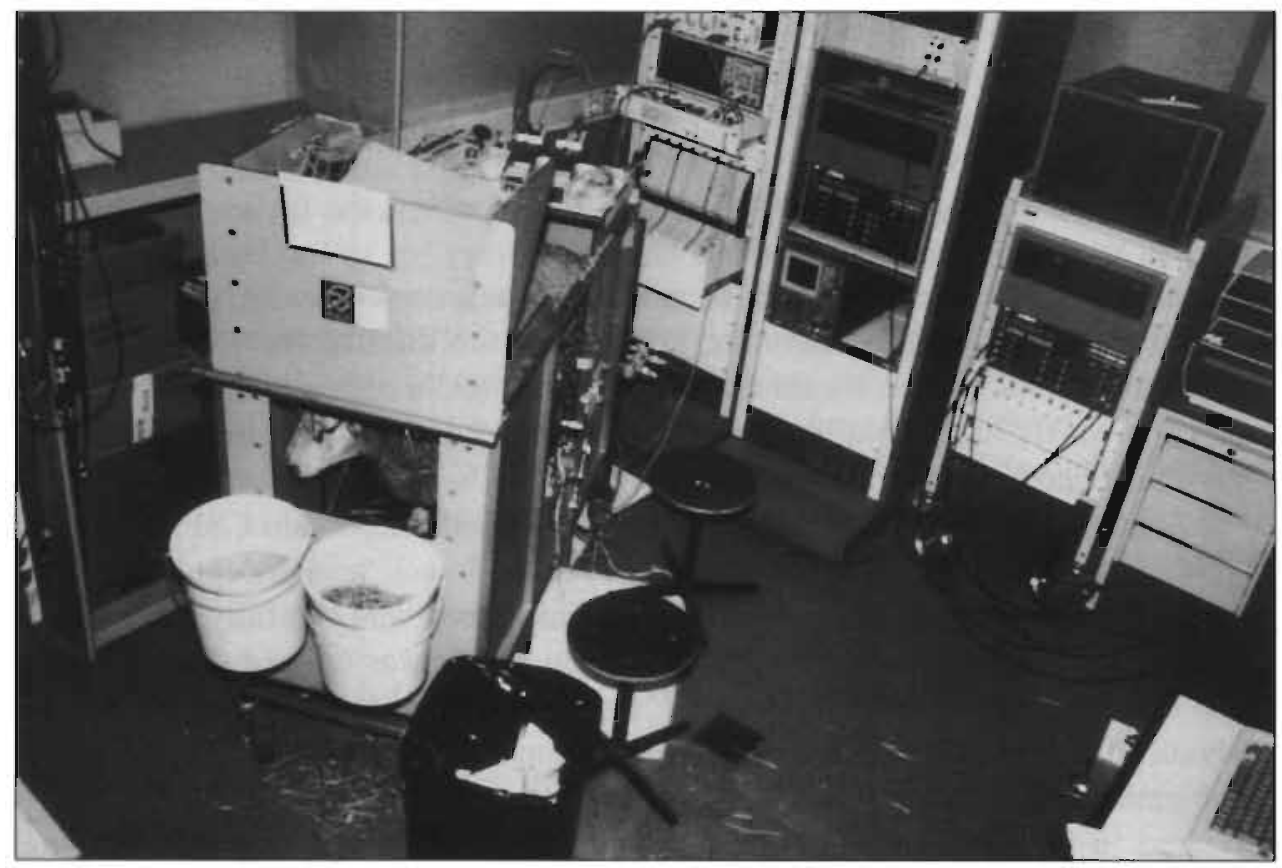

Figure 3.2. The cage in which the ewe recovered from surgery, and some equipment used for data recording and analyzing.

\subsection{Measurements}

$\mathrm{Pa}$ and $\mathrm{Pv}$, tracheal pressure, and amniotic pressure were determined with the zero point at the level of the ewe's spine. These signals, together with the fetal ECG, the fetal ECoG and the FHR, derived from the pulsatile signal of the femoral artery, were fed into bioelectric amplifiers (Hewlett Packard 8800 series, Andover, Massachusetts, USA), displayed on a monitor, recorded on an eight-channel strip chart recorder, stored on magnetic tape, and digitized and analyzed with a computer. An example of a tracing obtained is shown in Figure 3.3. 


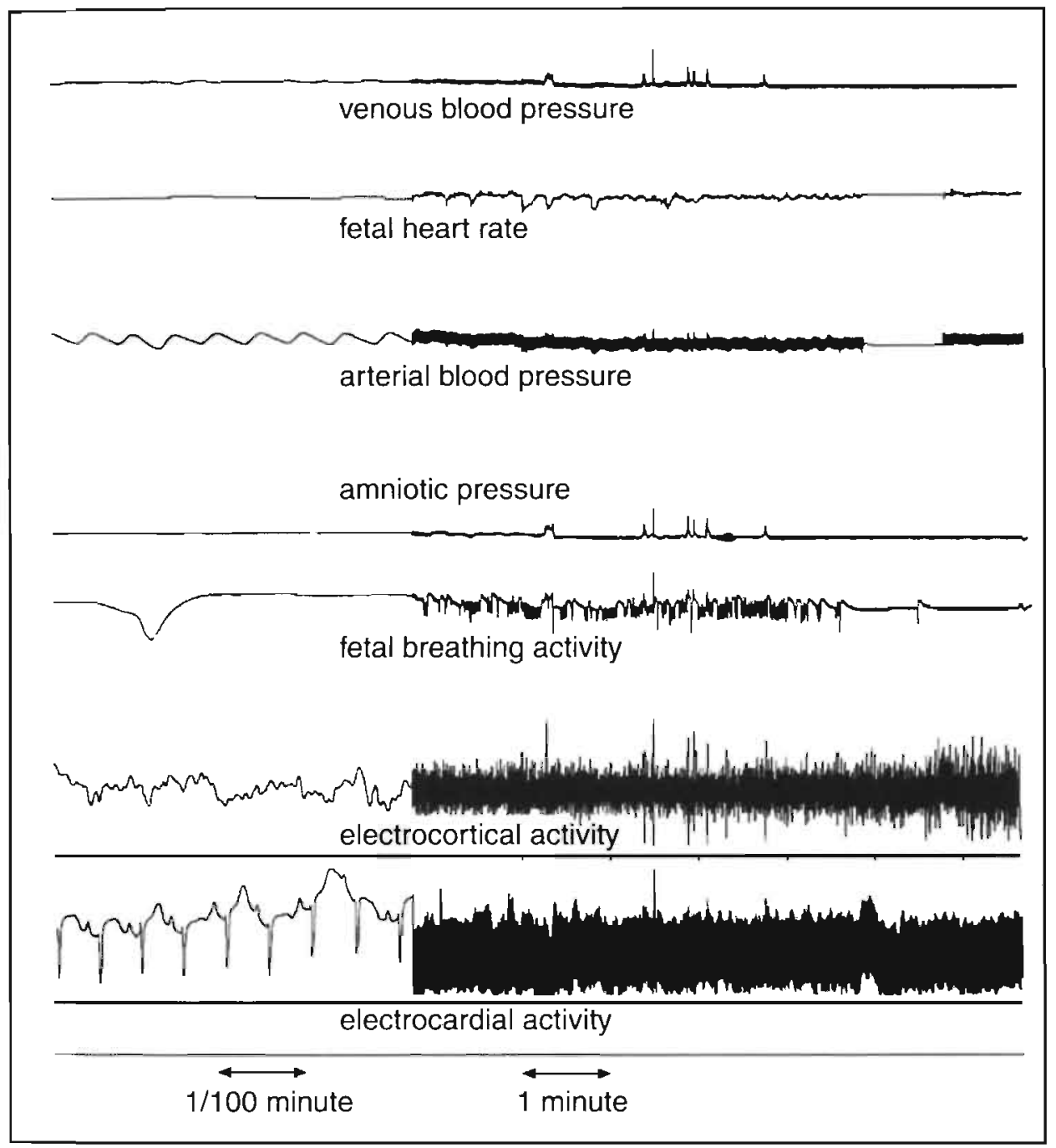

Figure 3.3. Registration of a fetus during the baseline period. Parameters measured arc indicated. The left part of the figure is recorded at $3 \mathrm{~m} / \mathrm{min}$, the right part at $3 \mathrm{~cm} / \mathrm{min}$.

Regional blood flow was measured with radioactive microspheres. With this technique microspheres with various energy spectra are injected into the heart. The left ventricle acts as a mixing chamber. Well-mixed spheres will subsequently be carried by the arterial system to various organs and tissues, and due to their diameter of $15 \mu \mathrm{m}$ the microspheres will be trapped in the microcirculation during their first passage. The total amount of injected microspheres will be distributed in proportion to the blood flow to each organ, presuming even distribution of the spheres in the arterial blood (3). In random order, one out of five available 
microspheres $\left({ }^{46}\right.$ Scandium, ${ }^{95}$ Niobium, ${ }^{103}$ Ruthenium, ${ }^{113}$ Tin, and ${ }^{141}$ Cerium) was injected. Aggregation of microspheres was prevented by adding $0.05 \%$ Tween 80 to the injection medium. After homogenization in an ultrasonic waterbath at $39^{\circ} \mathrm{C}$ (Bransonic 5200, Soest, the Netherlands) for 20 minutes, approximately $0.5 \times 10^{6}$ microspheres were stirred on a vortex agitator. The $0.5 \times 10^{6}$ microspheres formed a volume of $0.5 \mathrm{~mL}$, which was mixed with approximately $2.0 \mathrm{~mL}$ of fetal blood, withdrawn from the inferior vena cava. After mixing, the $2.5 \mathrm{~mL}$ volume was infused over a period of 1 minute into the inferior vena cava (3). Reference sampling (1.80 mL/min) (Harvard Apparatus Ltd., Kent, England) was started from the brachiocephalic arch 30 seconds before infusion, continued during infusion, and stopped 1 minute after infusion. The rationale for reference sampling is to mimic a fetal organ from which the perfusion rate is exactly known. By comparing radioactivity in the reference sample with radioactivity in fetal organs, organ blood flow can be calculated. The precision of the radioactive microsphere technique depends mainly on the number of microspheres in reference samples and organs studied, and not on the amount of radioactivity, since counting accuracy can be improved by longer counting times if the count rate is very low. If however, small numbers of microspheres lead to marked random variability of their distribution to different organs, no degree of counting accuracy will correct the error (4). At least 400 microspheres in each reference and tissue sample are considered necessary for reliable measurements (4). Since the microspheres act as emboli, obstructing the vessel and causing cellular damage distal from the site of entrapment, the number of spheres injected must be chosen carefully: too much will lead to ischemic tissue damage whereas too little will give rise to inaccuracy.

Blood gas values and $\mathrm{pH}$ from the fetal aortic arch were measured with an automated analyzer (AVL or AVL 995, Radiometer, Copenhagen, Denmark) and corrected for $39^{\circ} \mathrm{C}$. The percentage of saturation of $\mathrm{Hb}$ was measured (OSM2 Hemoximeter, Radiometer). Measurement of the arterial $\mathrm{PO}_{2}$ alone might lead to erroneous results, since retention of $\mathrm{CO}_{2}$ induces a respiratory acidosis, which due to the rightward shift of the oxygen dissociation curve tends to result in an oxygen tension being maintained despite a substantial drop in arterial oxygen content $\left(\left[\mathrm{O}_{2}\right] \mathrm{a}\right)(5)$. Therefore, a more valid measure of oxygen amount in arterial fetal blood is the $\left[\mathrm{O}_{2}\right] \mathrm{a}$, calculated as follows:

$\left[\mathrm{O}_{2}\right] \mathrm{a}(\mathrm{mM})=\mathrm{Hb}$ level $(\mathrm{mM}) \times \mathrm{Hb}$ oxygen saturation $(\% / 100)+\mathrm{PO}_{2}(\mathrm{~mm} \mathrm{Hg}) \times 0.0031$.

In this calculation the freely dissolved oxygen is represented by $\left(\mathrm{PO}_{2} \mathrm{x}\right.$ 0.0031 ). This additional factor accounts for a small amount of oxygen and is not mentioned any further in $\left[\mathrm{O}_{2}\right]$ a calculations.

Atter the microsphere injection, $2 \mathrm{~mL}$ of blood were withdrawn from the axillary artery and centrifuged ( 3 minutes at 13,000 revolutions/min). Serum was frozen in liquid nitrogen and stored at $-73^{\circ} \mathrm{C}$. After all experiments had ended serum lactate concentrations were determined in these samples. 
CSF obtained during surgery and during the experiment was withdrawn with a $1 \mathrm{~mL}$ syringe, centrifuged ( 3 minutes at 13,000 revolutions $/ \mathrm{min}$ ), frozen in liquid nitrogen, and stored at $-73^{\circ} \mathrm{C}$. Levels of nucleosides and purine bases in CSF were determined with high performance liquid chromatography, discussed in chapter 8 .

\subsection{Experiments}

Gestational age during experiments varied between 113 and 132 days (mean $\pm \mathrm{SD}=123.5 \pm 3.0$ days). Baseline values for $\mathrm{FHR}, \mathrm{Pa}$, and $\mathrm{Pv}$ were obtained during a control period of at least 2 hours. Fetal acid-base balance was analyzed every 15 minutes. The amount of blood sampled during the entire experiment was less than $30 \mathrm{~mL}$ (which is less than $10 \%$ of the initial fetal blood volume). Since the experiments lasted for a prolonged period this is not considered to result in major alterations in fetal cardiovascular functioning or metabolic condition: the fetus will rapidly return its blood volume to normal by increasing plasma renin activity, arginin vasopressin, and norepinephrine levels (6).

Individual gestational ages, treatment and survival, as well as the chapter in which each fetus is used, are depicted in Table 3.1. The experimental set-up for all 47 instrumented fetuses is comparable and shown in Figure 3.4.

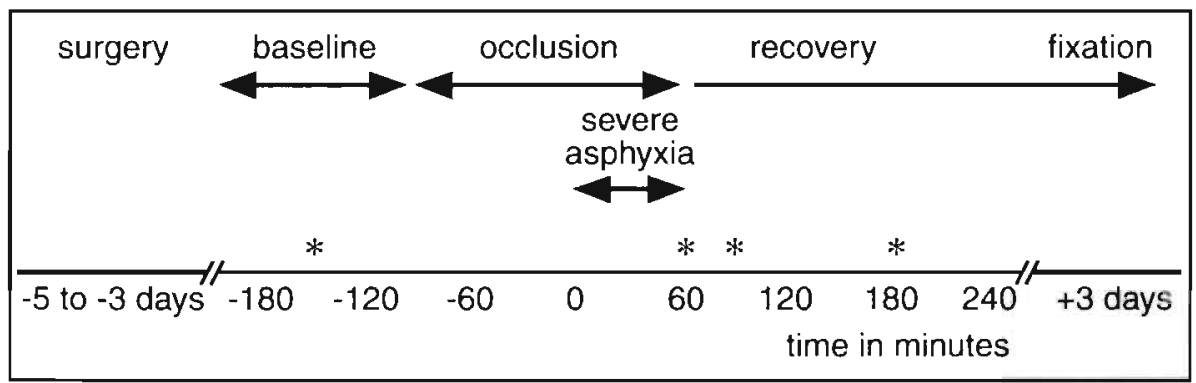

Figure 3.4. Experimental protocol. Asterisks indicate fetal blood flow measurements and fetal serum sampling.

Animals received either flunarizine (chapter 4), the adenosine transport inhibiting drug R-75231 (chapter 5) or the inert solvent of both drugs (10\% 5-OHpropyl-B-cyclodextrine) at various moments during the experiment. Detailed information on administration, pharmacology, and effects of these drugs is described in the chapters mentioned above. Each experiment started with a baseline period of at least 2 hours. During this baseline period radioactive microspheres were administered to determine fetal blood flow to various organs. When fetal metabolic condition was considered abnormal $(\mathrm{pH}<7.32$, or $\mathrm{BE}<-6.0$ $\mathrm{mM}$ ) experiments were not performed. 
Fetal asphyxia was induced by stepwise inflation of the balloon occluder around the maternal common internal iliac artery. Several methods have been described to induce fetal asphyxia: umbilical cord occlusion, maternal hypoxemia, and restriction of uterine perfusion. Fetal cardiovascular responses to various types of stress are clearly different (7). Umbilical cord occlusion results in immediate cardiovascular reactions as hypertension and bradycardia and resembles variable fetal decelerations during uterine contractions. Prolonged severe umbilical blood flow obstruction will lead to fetal asphyxia but is associated with fetal cardiovascular changes, since occlusion leads to an acute increase in systemic resistance. Maternal inhalation of a hypoxic gas mixture is associated with maternal hyperventilation, discomfort, release of maternal catecholamines, and disturbances in recording of fetal signals. Therefore, this method may not be preferable. Restriction of uterine perfusion does not lead to maternal discomfort and is closely resembling acute fetal oxygen shortage. Therefore, we preferred this method to induce fetal asphyxia.

During the experiment the preductal aortic fetal acid-base balance and blood gases were determined every 15 minutes. To maintain the fetus in a stable hemodynamic condition, uterine blood flow was gradually reduced over a period of 60 to 90 minutes, until fetal $\left[\mathrm{O}_{2}\right]$ a reached a value of approximately $35 \%$ of baseline level and/or fetal $\mathrm{pH}<7.15$. In human literature a $\mathrm{pH}$ of 7.15 is approximately the mean - $2 \mathrm{SD}(8,9)$. The total duration of occlusion could not be standardized. Apparently the collateral blood supply to the pregnant uterine horn varies considerably between animals. The time necessary to reach an $\left[\mathrm{O}_{2}\right]$ a of $35 \%$ of baseline varied, especially since we aimed for a stable FHR, i.e., without a reflex bradycardia. An $\left[\mathrm{O}_{2}\right]$ a of $35 \%$ of baseline was considered the start of fetal asphyxia, and therefore called time $=0 \mathrm{~min}$. The $\left[\mathrm{O}_{2}\right] \mathrm{a}$ was maintained at the same level for 1 hour, during which the arterial $\mathrm{pH}$ decreased further. At the end of this period of severe asphyxia, microspheres were again administered to determine fetal blood flow. Uterine blood flow obstruction was then discontinued by emptying the balloon occluder. This moment corresponds with time $=60 \mathrm{~min}$. Fetal blood flow was determined again at time $=90$ and $180 \mathrm{~min}$, corresponding with 0.5 and 2 hours after release of the occluder. Fetal recovery was monitored, and after disconnecting the fetus from the amplifiers fetal $\mathrm{Pa}$ was checked regularly to determine survival interval. During the disconnected period, no blood gas analysis was performed.

\subsection{Fixation procedure and histologic evaluation}

Three days after fetal asphyxia (i.e., 6 to 8 days after instrumentation) a relaparotomy was performed under general anesthesia. The fetus was completely heparinized by 15,000 U intravenous heparin. The fetal heart was approached by median thoracotomy. A blunt steel catheter was inserted in the left ventricle. The right atrium was opened, and $500 \mathrm{~mL}$ of isotonic and buffered isocolloidal fluid 
Table 3.1. Characteristics of the 47 fetal lambs used

\begin{tabular}{|c|c|c|c|c|c|}
\hline $\begin{array}{c}\text { animal } \\
\text { number }\end{array}$ & $\begin{array}{l}\text { gestatic } \\
\text { surgery }\end{array}$ & $\begin{array}{l}\text { al age at: } \\
\text { experiment }\end{array}$ & treatment & $\begin{array}{c}\text { used in } \\
\text { chapter no. }\end{array}$ & $\begin{array}{l}\text { survival } \\
\text { (in hours) }\end{array}$ \\
\hline 8902 & 121 & 125 & flunarizine & 7 & 2 \\
\hline 9002 & 117 & 121 & flunarizine & 4,7 & 72 \\
\hline 9003 & 116 & 120 & soivent & 4,7 & 10 \\
\hline 9005 & 118 & 123 & solvent & 4,7 & 2 \\
\hline 9006 & 115 & 119 & solvent & 4,7 & 1 \\
\hline 9007 & 120 & 124 & flunarizine & $4,7,8$ & 24 \\
\hline 9008 & 116 & 120 & flunarizine & $4,7,8$ & 2 \\
\hline 9009 & 123 & 126 & solvent & $4,7,8$ & 4.5 \\
\hline 9013 & 118 & 121 & flunarizine & $4,7,8$ & 4.5 \\
\hline 9014 & 121 & 124 & solvent & $4,5,7$ & 5 \\
\hline 9015 & 121 & 126 & solvent & $4,7,8$ & 5 \\
\hline 9016 & 124 & 129 & solvent & $4,5,7$ & 5 \\
\hline 9017 & 123 & 128 & solvent & $4,5,7$ & 24 \\
\hline 9018 & 128 & 132 & flunarizine & 7,8 & 3 \\
\hline 9020 & 110 & 113 & solvent & $5,7,8$ & 3 \\
\hline 9023 & 120 & 124 & flunarizine & 7.8 & 12 \\
\hline 9025 & 118 & 121 & flunarizine & 4.7 & 1 \\
\hline 9026 & 119 & 123 & flunarizine & 7 & 36 \\
\hline 9027 & 120 & 123 & flunarizine & 7,8 & 72 \\
\hline 9028 & 120 & 124 & $\mathrm{R}-75231$ & 7,8 & 1 \\
\hline 9101 & 122 & 126 & R-75231 & $5,6,7,8$ & 72 \\
\hline 9103 & 120 & 125 & $\mathrm{R}-75231$ & 7,8 & 0.5 \\
\hline 9106 & 120 & 124 & flunarizine & 4,7 & 72 \\
\hline 9107 & 119 & 122 & flunarizine & 4,7 & 72 \\
\hline 9108 & 120 & 124 & R-75231 & $5,6,7,8$ & 72 \\
\hline 9109 & 118 & 120 & R-75231 & $5,6,7,8$ & 72 \\
\hline 9110 & 120 & 123 & R-75231 & $5.6,7$ & 30 \\
\hline 9112 & 124 & 128 & R-75231 & $5,6,7$ & 22 \\
\hline 9113 & 120 & 123 & R-75231 & 5.6 .7 .8 & 72 \\
\hline 9114 & 121 & 126 & R-75231 & 7 & 2 \\
\hline 9115 & 119 & 123 & $\mathrm{R}-75231$ & $5.6,7,8$ & 72 \\
\hline 9116 & 123 & 125 & solvent & 5.7 .8 & 72 \\
\hline 9117 & 123 & 126 & solvent & $5.7,8$ & 96 \\
\hline 9119 & 118 & 123 & solvent & 5,7 & 20 \\
\hline 9120 & 118 & 123 & $R-75231$ & 7 & 1.5 \\
\hline 9126 & 119 & 122 & solvent & 7 & 0.5 \\
\hline 9128 & 119 & 122 & solvent & 7,8 & 2 \\
\hline 9204 & 120 & 122 & solvent & 7 & 12 \\
\hline 9206 & 120 & 123 & R-75231 & 7 & 1 \\
\hline 9207 & 121 & 124 & solvent & 7 & 72 \\
\hline 9210 & 119 & 122 & R-75231 & 7.8 & 1 \\
\hline 9214 & 123 & 125 & $\mathrm{R}-75231$ & $7 . x$ & 72 \\
\hline 9218 & 119 & 122 & solvent & 7 & 30 \\
\hline 9303 & 124 & 128 & $\mathrm{R}-75231$ & 7 & 11 \\
\hline 9305 & 119 & 121 & R-75231 & 7 & 0.5 \\
\hline 9306 & 123 & 126 & solvent & 7 & 5 \\
\hline 9308 & 120 & 122 & solvent & 7.8 & 0 \\
\hline
\end{tabular}


(Haemaccel) at $39^{\circ} \mathrm{C}$ was infused into the left ventricle. The descending aorta was clamped. When the fluid leaking from the right atrium was colorless, the fetal brain was preserved by replacing the Haemaccel by Karnovsky's fixative (2\% formaldehyde and $2.5 \%$ glutaraldehyde in phosphate buffer $0.1 \mathrm{~mol} / \mathrm{L}, \mathrm{pH} 7.40$ ), approximately $1 \mathrm{~L}$ at room temperature. The time lag of 3 days between asphyxia and histologic fixation is necessary to allow delayed neuronal cell death to become histologically manifest (10). Subsequently, fetuses were removed and weighed, and correct catheter placement was confirmed at autopsy after 3 days or earlier in case of fetal death. After perfusion and 1 day immersion fixation in Karnovsky's fixative the fetal brain was removed from the skull and was sampled for CBF determination and histologic analysis.

Histologic analysis was performed according to a stereotaxic atlas of the ovine fetal brain (11). After scintillation counting, vibratome sections $(200 \mu \mathrm{m})$ were cut from eight cerebral areas: frontal cortex, parietal cortex, temporal cortex, striatum, hippocampus, cerebellum, thalamus and medulla oblongata. Sections were post-fixed in $2 \%$ osmium tetroxide, buffered with barbital acetate $(0.05$ $\mathrm{mol} / \mathrm{L}, \mathrm{pH} 7.40$ ), dehydrated in graded series of ethanol, and routinely embedded in Epon. Light microscopic evaluation was performed on $2 \mu \mathrm{m}$ sections stained with toluidine blue. Fixation quality was scored on a 10 -point scale (12) in which two characteristic types of hypoxic cell changes were evaluated: edematous cell changes, mainly involving the glial compartment, and coagulative neuronal cell changes. These cell changes were also scored on a 10-point scale (12).

\subsection{Calculations and data analysis}

FHR, $\mathrm{Pa}$, and $\mathrm{Pv}$ were corrected for amniotic pressure, and averaged over 10 seconds periods by computer. Five of these epochs were averaged to calculate mean $\mathrm{Pa}$ and $\mathrm{Pv}$. Perfusion pressure (Pa-Pv) was calculated every 15 minutes.

The fetus was dissected to perform fetal blood flow measurements and histology. Tissue samples were weighed $( \pm 1 \mathrm{~g})$, put into test tubes, and additionally preserved in Karnovsky's fixative solution. For reasons of accuracy, MBF was calculated from the mean flow of three samples out of left ventricular base, middle, and apex of the fetal heart. The fetal cerebrum was dissected in the eight anatomical entities mentioned before. The energy spectra of all isotopes used in each animal were counted simultaneously. Radioactivity in tissue and blood samples was measured with a gamma scintillation counter and sample changer system (analyzer model 45, Molsgaard Medical, Horsholm, Denmark). Fetal blood flow was calculated with an ND680 programmable analyzer/computer system (Nuclear Data GmbH, Frankfurt, Germany). Since fetal myocardium and brain are well-perfused organs, the amount of microspheres injected was sufficient to find at least 400 microspheres in each sample, which is considered the minimum necessary for accurate measurements (4).

For the ECG analysis the tape recorded fetal ECG was run through a 
commercially available cardiotocograph and ECG-analyzer (ST-analyzer, Cinventa $\mathrm{AB}$, Mölndal, Sweden), and analyzed with the aid of a microprocessor system supplied by the same company. Filtering and signal processing used in this analysis are described in chapter 7.

\subsection{Statistics}

Whenever groups are compared with each other, the two-tailed MannWhitney $\mathrm{U}$ test is used. Differences within groups are compared with the Wilcoxon matched-pairs signed-ranks test or with the Friedman two-way analysis of variance, with time as the repeated measure. Occasionally Log rank-tests and paired $t$-tests are used. To investigate the correlation between ECG-changes and changes in $\mathrm{pH}$ and $\left[\mathrm{O}_{2}\right]$ a Pearson correlation coefficients are determined. A $\mathrm{p}<0.05$ is accepted as level of statistical significance.

\subsection{References}

1. Evers JLH 1978 The cardiac pre-ejection period during prenatal life. Thesis, Nijmegen, the Netherlands

2. Bissonnette JM, Hohimer AR, Richardson BS 1981 Ventriculocisternal cerebrospinal perfusion in unanesthetized fetal lambs. J Appl Physiol 50:880-88.3

3. Rudolph AM, Heymann MA 1967 The circulation of the fetus in utero. Circ Res 21:163-184

4. Buckberg GD, Luck JC, Payne B, Hoffman JIE, Archie JP, Fixler DE 1971 Some sources of error in measuring regional blood flow with radioactive microspheres. $\mathrm{J}$ Appl Physiol 31:598-604

5. Jones MD, Traystman RJ 1984 Cerebral oxygenation of the fetus, newborn, and adult. Sem Perinat 8:205-216

6. Brace RA, Cheung CY 1986 Fetal cardiovascular and endocrine responses to prolonged fetal hemorrhage. Am J Physiol 251:R417-R424

7. Jensen A, Roman C, Rudolph AM 1991 Effects of reducing uterine blood flow on fetal blood flow distribution and oxygen delivery. J Dev Physiol 15:309-323

8. Ruth VJ, Raivio KO 1988 Perinatal brain damage: predictive value of metabolic acidosis and the Apgar score. Br Med J 297:24-27

9. Carter BS, Haverkamp AD, Merenstein GB 1993 The definition of acute perinatal asphyxia. Clin Perinat 20:287-304

10. Pulsinelli WA, Brierley JB, Plum JB 1982 Temporal profile of neuronal damage in a model of transient forebrain ischemia. Ann Neurol 11:491-498

11. Gluckman PD, Parsons Y 1984 Stereotaxic neurosurgery on the ovine fetus. In: Nathanielsz PW (ed) Animal models in fetal medicine (III). Perinatology Press, New York, pp 69-107

12. Van Reempts JLH 1984 The hypoxic brain: histological and ultrastructural aspects. Behav Brain Res 14:99-108 


\section{Chapter 4}

\section{Possible neuroprotective properties of flunarizine infused after asphyxia in fetal lambs are not explained by effects on cerebral blood flow or systemic blood pressure}

Harmen H. de Haan a, Jos L.H. Van Reempts ${ }^{\text {b }}$, Marcel Borgers ${ }^{b}$, Jelte de Haan a, Johannes S.H. Vles ${ }^{\mathrm{c}}$ and Tom H.M. Hasaart ${ }^{\mathrm{a}}$

From the Departments of Obstetrics and Gynecology ${ }^{a}$ and Neurology

University Hospital, Maastricht, the Netherlands, and the Department of Life Sciences,

Janssen Research Foundation, B-2340 Beerse, Belgium. ${ }^{\text {b }}$

Pediatric Research 1993: 34: 379-384 


\begin{abstract}
Neuroprotective properties of the calcium channel blocker flunarizine have been reported after hypoxic-ischemic insults in immature, infant, and adult rais. However, its effect on fetal regional cerebral blood flow (CBF) and systemic blood pressure after severe asphyxia is not known. In 15 fetal lambs ( 3 to 5 days after surgery; gestational age at the experiment $123.2 \pm 2.5$ days) arterial oxygen content was progressively reduced to $30 \%$ by restriction of uterine blood flow with an inflatable balloon occluder around the maternal common internal iliac artery. The regional $C B F$ was measured with radioactive microspheres at baseline condition, after 1 hour of severe asphyxia, and at 30 and 120 minutes in the recovery phase. Immediately after the end of the occlusion period fetuses randomly received either flunarizine or its solvent $10.5 \mathrm{mg} / \mathrm{kg}$ estimated fetal weight). No differences in regional CBF changes between groups were observed during and after asphyxia. Changes in arterial blood pressure or fetal heart rate, due to flunarizine, could not be shown either. Only five fetuses (=33\%) survived this degree of asphyxia longer than 12 hours: four of the flunarizine-treated group and one of the control group. It is unlikely that this possible protective property of the drug is caused by its influence on regional $C B F$, on arterial blood pressure, or on fetal heart rate in the phase immediately after asphyxia.
\end{abstract}




\section{Introduction}

Brain damage due to perinatal asphyxia is a clinically relevant target of research (1). In this respect important results have been obtained in neonatal and in adult rats in which calcium channel blockers have shown structural and functional brain protective properties in various experimental setups. Newborn and infant rats, pretreated with the class IV calcium channel blocker flunarizine (2) and submitted to hypoxic-ischemic insults, had less brain damage as compared to nontreated controls (3-5). Flunarizine treatment after induction of cortical damage in adult rats improved brain function and reduced infarct size (6). Regarding blood flow, flunarizine decreased the rate of the stimulated calcium influx into vascular smooth muscle cells of the rat tail and rabbit ear and, therefore, inhibited the peripheral vasoconstriction and vasospasm evoked by tissue anoxia (7). After 10 minutes of complete ischemia in the adult dog, the brain protective effect of nimodipine, a class II calcium channel blocker (2), was attributed to a nearly doubled cerebral blood flow (8).

The fetus reacts to hypoxia with an increase in cerebral blood flow to maintain cerebral oxygen delivery (9). The effect of flunarizine on fetal regional CBF and on fetal cardiovascular parameters is not known. To mimic treatment after fetal pathophysiology, we chose to administer flunarizine after a period of severe asphyxia. The lack of oxygen results in energy failure, which leads to impeded ATP-dependent $\mathrm{Na}^{+} / \mathrm{K}^{+}$-transport. The ensuing decrease in membrane potential opens voltage-dependent calcium gates. Additionally, the decrease of the transmembrane sodium gradient diminishes outward calcium transport. Intracellular influx of calcium is an important factor in the mechanism of cell death (10). The intracellular calcium concentration is normally maintained near $0.1 \mu \mathrm{M}$, which is 10,000 fold less than the extracellular calcium concentration (11). Calcium shifts occurring with ischemic-anoxic energy failure are responsible for massive calcium overload in neurons, leading to activation of phospholipases. This results in accumulation of free fatty acids, and in swelling and edema of neurons. The latter further compromises oxygen supply (12).

Flunarizine, a possible neuroprotective drug, was studied in the chronic fetal sheep model, which allows accurate measurements of regional CBF, FHR, $\mathrm{Pa}$, and Pv during and after severe fetal asphyxia. The hypothesis tested was that flunarizine improves regional CBF in the phase immediately after asphyxia and that this may lead to improved fetal outcome after severe asphyxia.

\section{Material and methods}

\section{Surgery}

Surgery was performed in 15 pregnant Dutch Texel sheep. Gestational age varied between 115 and 124 days (mean $\pm S D=119.2 \pm 2.3$ days, term $=147$ days).

General anesthesia was induced with pentobarbital i.v. and maintained with $1 \%$ halothane in a 2:1 mixture of nitrous oxide and oxygen. Before surgery, 
the ewes received $1 \mathrm{~g}$ of ampicillin i.v. Instrumentation was performed as described previously (13). Briefly, a paramedian abdominal incision was made, and an inflatable balloon occluder was placed around the maternal common internal iliac artery. Catheters were inserted in the fetal axillary and femoral artery, and the tips were advanced to the level of the brachiocephalic trunk and descending aorta, respectively. In addition, fetal catheters were placed in the femoral vein, the tip advanced into the inferior vena cava, and in the amniotic cavity. Electrodes were placed to record the fetal ECG and ECoG, and a catheter in the spinal cistern allowing sampling of CSF. Catheters and wires were exteriorized to the ewe's flank.

Ewes were housed in individual cages, had free access to food and water and were allowed to recover from surgery for at least 3 days before experiments were started. A continuous slow infusion ( $1 \mathrm{~mL} /$ hour) of heparin in saline (10 $\mathrm{U} / \mathrm{mL}$ ) was used to maintain patency of fetal arterial and venous catheters. Guidelines for care and use of animals as approved by the local Animal Medical Ethics Committee were followed.

\section{Measurements}

Regional CBF was measured by means of radioactive microspheres with a diameter of $15 \mu \mathrm{m}$. At random, one out of four available microspheres $\left({ }^{95} \mathrm{Nb}\right.$, ${ }^{103} \mathrm{Ru},{ }^{113} \mathrm{Sn}$, and ${ }^{14 /} \mathrm{Ce}$ ) was injected. Aggregation was prevented by adding $0.05 \%$ Tween 80 to the medium. After homogenization in an ultrasonic $39^{\circ} \mathrm{C}$ water bath (Bransonic 5200, Soest, the Netherlands) for 20 minutes, approximately $0.5 \times 10^{6}$ microspheres were stirred on a vortex agitator and infused gradually over a period of 1 minute into the inferior vena cava (14). Reference sampling (1.80 $\mathrm{mL} / \mathrm{min}$ ) was started from the brachiocephalic arch, 30 seconds before infusion, continued during infusion, and stopped 1 minute after infusion, using a variable speed peristaltic pump (Harvard Apparatus 1210, Edenbridge, England).

$\mathrm{Pa}, \mathrm{Pv}$, and amniotic pressure were determined with the zero point at the level of the ewe's spine. These signals, together with the FHR derived from the pulsatile signal of the femoral artery, were led to a bioelectric amplifier (HewlettPackard 8800 series, Andover, Mass., USA), displayed on a monitor, recorded on an eight-channel strip chart recorder, stored on magnetic tape, and digitized and analyzed with a computer.

Immediately after microsphere injection, $2 \mathrm{~mL}$ of blood were withdrawn from the axillary artery and centrifuged ( 3 minutes at 13,000 revolutions $/ \mathrm{min}$ ). Scrum was frozen in liquid nitrogen and stored at $-73^{\circ} \mathrm{C}$, to determine lactate concentrations. Blood gas values and $\mathrm{pH}$ from the fetal aortic arch were measured with an automated analyzer (AVL, Radiometer, Copenhagen, Denmark) and corrected for $39^{\circ} \mathrm{C}$. Hb saturation was measured with an hemoximeter (OSM2 Hemoximeter, Radiometer). The $\left[\mathrm{O}_{2}\right] \mathrm{a}$ was calculated as follows: $\left[\mathrm{O}_{2}\right] \mathrm{a}(\mathrm{mM})=$ $\mathrm{Hb}$ concentration $(\mathrm{mM}) \times \mathrm{Hb}$ oxygen saturation $(\% / 100)$. 


\section{Experiments}

Gestational age at the beginning of experiments varied between 119 and 129 days (mean $\pm \mathrm{SD}=123.2 \pm 2.5$ days). Baseline values were obtained during a control period of 2 hours. Fetal acid-base balance was analyzed every 15 minutes.

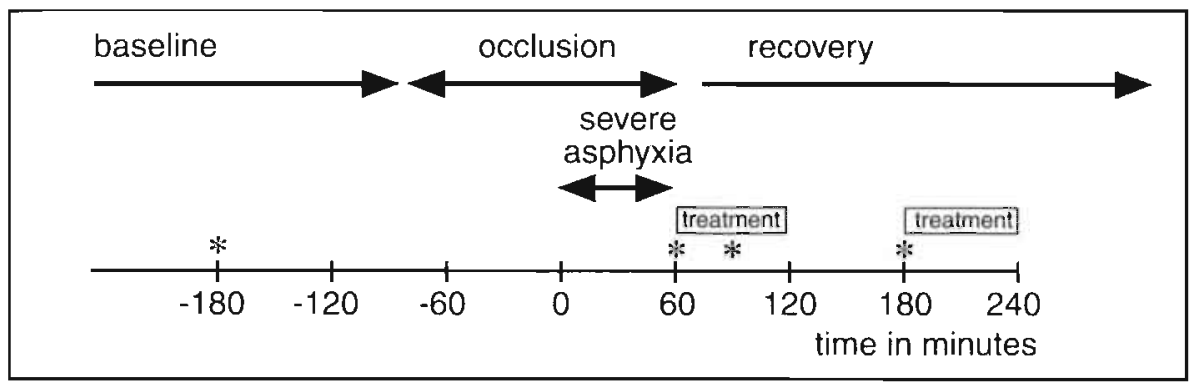

Figure 4.1. Experimental protocol. Asterisks indicate regional CBF measurement. The last two measurements correspond with post- 1 and post- 2 in the text. Treatment consisted of either flunarizine or its solvent.

Figure 4.1 shows the experimental protocol. After measurement of regional $\mathrm{CBF}$ in the baseline control period, severe asphyxia was induced by gradual reduction of maternal uterine blood flow by stepwise inflation of the balloon occluder around the common internal iliac artery. To maintain the fetus in a stable hemodynamic condition, uterine blood flow was gradually reduced over a period of 90 to 120 minutes until fetal $\left[\mathrm{O}_{2}\right]$ a was reduced to approximately $30 \%$ of the baseline value. This latter asphyxial condition was maintained for 1 hour. At the end of this period, at time $=60 \mathrm{~min}$, regional CBF was remeasured (asterisk in Figure 4.1). Uterine blood flow obstruction was then discontinued by emptying the balloon occluder. At this moment the animals were randomized and treatment was started; seven fetuses received flunarizine $(0.5 \mathrm{mg} / \mathrm{kg}$ estimated fetal weight), whereas the control group consisted of eight fetuses receiving the solvent, $10 \% 5$ $\mathrm{OH}$-propyl-B-cyclodextrine. To avoid possible side effects such as systemic hypotension and tachycardia, we administered flunarizine or the solvent in 2 dosages over a period of 1 hour infused in the axillary artery. The first dosage was given immediately after the period of severe asphyxia, the second infusion started at time $=180 \mathrm{~min}$. In the first animals fetal serum levels of flunarizine were determined during various moments in the experiment. The regional CBF was again determined at time $=90 \mathrm{~min}$ (post- 1 , which is during the first treatment) and at time $=180 \mathrm{~min}$ (post-2, just before the second treatment).

The experiment was ended when either the fetus had died or, in case of fetal survival, after 3 days. Then the ewe was killed by an overdose of pentobarbital, the fetus was removed and weighed, and correct catheter placement was confirmed. The fetal cerebrum was dissected into eight different anatomical entities: frontal cortex, parietal cortex, temporal cortex, striatum, hippocampus, cerebellum, thalamus, and medulla oblongata. 


\section{Calculations and data analysis}

Different tissue samples were weighed $( \pm 1 \mathrm{~g})$, put into test tubes, and preserved in fixative containing a $2 \%$ formaldehyde and $2.5 \%$ glutaraldehyde solution. All four isotopes were counted simultaneously. Radioactivity in the eight cerebral entities and in the reference samples was measured with an automatic gamma counter and sample changer system (analyzer model 45, Molsgaard Medical, Horsholm, Denmark). The CBF was calculated with an ND680 programmable analyzer/computer system (Nuclear Data GmbH, Frankfurt, Germany).

FHR, $\mathrm{Pa}$, and $\mathrm{Pv}$, corrected for amniotic pressure, were averaged over 10 seconds periods using a computer program. Five of these epochs were averaged to calculate mean values. Data obtained at several moments in the experiment within one group were compared with a Friedman two-way analysis of variance, with time as the repeated measure. Differences between the flunarizine-treated group and the control group were tested with the two-tailed Mann-Whitney U test. A p $<0.05$ was taken to represent statistical significance.

\section{Results}

Infusion of flunarizine resulted in fetal serum levels well within the therapeutic range, i.e., $>200 \mu \mathrm{g}$ flunarizine/L serum (15).

Table 4.1 summarizes the fetal acid-base balance at the four moments of blood flow measurement. $\left[\mathrm{O}_{2}\right] \mathrm{a}(\mathrm{mM}), \mathrm{pH}, \mathrm{PCO}_{2}(\mathrm{kPa}), \mathrm{BE}(\mathrm{mM})$ and serum lactate concentration (mM) are expressed at baseline condition, at the end of the 1 hour period of severe asphyxia (time $=60 \mathrm{~min}$ ), at post- 1 , and at post- 2 for both the flunarizine-treated group and the control group. Uterine blood flow restriction resulted in a reduction of the $\left[\mathrm{O}_{2}\right]$ a to about $30 \%$ of baseline level. After 1 hour of severe asphyxia the mean $\mathrm{pH}$ had decreased to 7.08 and 7.09 in the flunarizinetreated group and the control group, respectively. In the recovery phase, the mean oxygen saturation did not return to baseline values. This resulted in an $\left[\mathrm{O}_{2}\right] \mathrm{a}$ significantly below baseline levels at post-1 and post-2, whereas $\mathrm{pH}$ and $\mathrm{BE}$ increased only slightly. Serum lactate concentrations at post- 1 and post- 2 are in the same range as in the period of severe asphyxia.

Table 4.2 shows the weight specific regional $\mathrm{CBF}$ in $\mathrm{mL} / \mathrm{min} \times 100 \mathrm{~g}$ during baseline, asphyxia and post asphyxia, for eight cerebral areas. The amount of microspheres used was sufficient, as all of the dissected tissues and samples contained more than 400 microspheres (16). Adequate mixing was proven by the absence of significant differences between the amount of microspheres in left and right kidney. Baseline levels of blood flow in phylogenetic older structures as cerebellum, thalamus and especially medulla oblongata were higher compared with younger structures as cortices (Mann-Whitney $U$ test, $p<0.05$ ). Blood flow tonearly all parts of the brain more than doubled in response to asphyxia. At post1 , during the first treatment, mean CBF decreased compared with asphyxia but had 
Table 4.1. Fetal acid-base balance

\begin{tabular}{|l|c|c|c|c|}
\hline Flunarizine group & Baseline & Asphyxia & Post-1 & Post-2 \\
\hline$\left[\mathrm{O}_{2}\right] \mathrm{a}(\mathrm{mM})$ & $3.86 \pm 0.44$ & $1.13 \pm 0.24^{*}$ & $2.64 \pm 0.46^{*}$ & $2.48 \pm 0.73^{*}$ \\
$\mathrm{pH}$ & $7.37 \pm 0.02$ & $7.08 \pm 0.01^{*}$ & $7.13 \pm 0.02^{*}$ & $7.27 \pm 0.04^{*}$ \\
$\mathrm{PCO}_{2}(\mathrm{kPa})$ & $4.79 \pm 0.28$ & $6.78 \pm 0.49^{*}$ & $5.52 \pm 0.26^{*}$ & $5.75 \pm 0.41$ \\
base excess $(\mathrm{mM})$ & $-3.5 \pm 0.9$ & $-15.4 \pm 1.1^{*}$ & $-14.8 \pm 1.4^{*}$ & $-9.7 \pm 2.4^{*}$ \\
lactate $(\mathrm{mM})$ & $1.5 \pm 0.3$ & $11.2 \pm 2.6^{*}$ & $9.4 \pm 0.2^{*}$ & $10.8 \pm 2.5^{*}$ \\
\hline Control group & Baseline & Asphyxia & Post-1 & Post-2 \\
\hline$\left[\mathrm{O}_{2}\right] \mathrm{a}(\mathrm{mM})$ & $3.38 \pm 0.34$ & $1.14 \pm 0.11^{*}$ & $1.86 \pm 0.29^{*}$ & $1.56 \pm 0.32^{*}$ \\
$\mathrm{pH}$ & $7.36 \pm 0.03$ & $7.09 \pm 0.03^{*}$ & $7.12 \pm 0.03^{*}$ & $7.15 \pm 0.07^{*}$ \\
$\mathrm{PCO} 2(\mathrm{kPa})$ & $4.61 \pm 0.24$ & $5.96 \pm 0.45^{*}$ & $4.82 \pm 0.23$ & $5.71 \pm 0.70$ \\
base excess $(\mathrm{mM})$ & $-3.5 \pm 1.0$ & $-17.0 \pm 0.7^{*}$ & $-16.8 \pm 1.3^{*}$ & $-13.3 \pm 2.6^{*}$ \\
lactate $(\mathrm{mM})$ & $1.8 \pm 0.2$ & $9.6 \pm 0.8^{*}$ & $9.0 \pm 0.4^{*}$ & $11.9 \pm 2.5^{*}$ \\
\hline
\end{tabular}

Values are expressed as mean \pm SEM. Asphyxia is at time $=60 \mathrm{~min}$, post -1 is at time $=90 \mathrm{~min}$, and post -2 is at time $=180 \mathrm{~min} . \mathrm{n}=8$ for the control group and $n=7$ for the flunarizine group, except at post -2 , when $n=7$ and $n=6$, respectively.

*: p<0.05 (asphyxia, post-1, or post-2 versus baseline; Friedman two-way ANOVA.

not yet returned to baseline values. At post-2, CBF in the flunarizine-treated group returned to baseline values, whereas CBF in the control group remained significantly higher compared with baseline. However, no differences were demonstrated between both groups, except for cerebellar flow, which was higher in the control group at post-2.

Fetal cardiovascular parameters at the four moments of regional C.BF measurement are summarized in Table 4.3. During the experiment FHR increased, whereas $\mathrm{Pa}$ and $\mathrm{Pv}$ did not change. Perfusion pressure (Pa-Pv) in individual animals was calculated and did not change during the experiment. No differences between groups could be demonstrated.

In Figure 4.2 the time course of FHR, $\mathrm{Pa},\left[\mathrm{O}_{2}\right] \mathrm{a}$, and $\mathrm{pH}$ for both experimental groups is depicted. The time scale on the ordinate is the same as in Figure 4.1. No significant differences between the groups in any of the four parameters were demonstrated (two-tailed Mann-Whitney U test).

The entire experiment resulted in a mean fetal blood loss of $28.5 \mathrm{~mL}$. This consisted of approximately $25 \times 0.1 \mathrm{~mL}$ for the various determinations of the fetal acid-base state, added to $4 \times 2.5 \mathrm{~min} \times 1.80 \mathrm{~mL} / \mathrm{min}$ for CBF measurements, added to $4 \times 2.0 \mathrm{~mL}$ for fetal serum analysis.

Fetal survival after severe asphyxia was poor: 10 animals (seven of the control group versus three of the flunarizine-treated group) died during the first 12 hours. In each group one animal survived a very short period, reducing the number of 
animals to $n=7$ and $n=6$ at post- 2 for the control group and the flunarizine treated group, respectively. In both groups one fetal lamb died between 1 and 3 days. The last three fetuses, all of the flunarizine-treated group, survived and were killed after 3 days.

Table 4.2. Regional cerebral blood flow

\begin{tabular}{|l|c|c|c|c|}
\hline Flunarizine group & Baseline & Asphyxia & Post-1 & Post-2 \\
\hline Frontal cortex & $110 \pm 32$ & $225 \pm 34^{*}$ & $184 \pm 50$ & $124 \pm 20$ \\
Parietal cortex & $117 \pm 28$ & $217 \pm 43^{*}$ & $187 \pm 62$ & $121 \pm 19$ \\
Temporal cortex & $126 \pm 39$ & $203 \pm 44^{*}$ & $165 \pm 57$ & $122 \pm 23$ \\
Striatum & $138 \pm 32$ & $265 \pm 51^{*}$ & $190 \pm 17$ & $139 \pm 21$ \\
& & & & \\
Hippocampus & $142 \pm 42$ & $247 \pm 51^{*}$ & $161 \pm 59$ & $149 \pm 23$ \\
Cerebellum & $192 \pm 71$ & $350 \pm 47^{*}$ & $293 \pm 68$ & $201 \pm 33^{*}$ \\
Thalamus & $210 \pm 61$ & $452 \pm 80^{*}$ & $329 \pm 85$ & $229 \pm 39$ \\
Medulla oblongata & $265 \pm 102$ & $558 \pm 76^{*}$ & $385 \pm 123$ & $292 \pm 70$ \\
Control group & Baseline & Asphyxia & Post-1 & Post-2 \\
\hline Frontal cortex & $114 \pm 25$ & $275 \pm 50^{*}$ & $188 \pm 34^{*}$ & $183 \pm 18^{*}$ \\
\hline Parietal cortex & $101 \pm 20$ & $260 \pm 46^{*}$ & $179 \pm 24^{*}$ & $164 \pm 14^{*}$ \\
Temporal cortex & $89 \pm 18$ & $221 \pm 41^{*}$ & $151 \pm 27$ & $152 \pm 15$ \\
Striatum & $148 \pm 30$ & $341 \pm 77^{*}$ & $223 \pm 27$ & $211 \pm 29^{*}$ \\
& & & & \\
Hippocampus & $120 \pm 21$ & $289 \pm 65^{*}$ & $173 \pm 37$ & $200 \pm 21^{*}$ \\
Cerebellum & $161 \pm 32$ & $422 \pm 64^{*}$ & $325 \pm 43$ & $307 \pm 22^{*} *$ \\
Thalamus & $201 \pm 29$ & $501 \pm 89^{*}$ & $320 \pm 48$ & $334 \pm 23^{*}$ \\
Medulla oblongata & $196 \pm 41$ & $578 \pm 92^{*}$ & $361 \pm 53$ & $377 \pm 39$ \\
\hline
\end{tabular}

Values are expressed as mean \pm SEM $(\mathrm{mL} / \mathrm{minx} 100 \mathrm{~g})$. Asphyxia is at time $=60 \mathrm{~min}$, post -1 is at time $=90 \mathrm{~min}$, and post -2 is at time $=180 \mathrm{~min}$. $n=8$ for the control group and $n=7$ for the flunarizine group. except at post- 2 when $n=7$ and $n=6$, respectively.

*: p<0.05 (asphyxia, post-1, or post-2 versus baseline; Friedman two-way ANOVA).

\#: p<0.05 (flunarizine-treated group versus control group; (wo-tailed Mann-Whitney U test).

\section{Discussion}

To rationalize the use of calcium channel blockers in the treatment of brain ischemia-anoxia, two major theories are developed. The first theory is the augmentation of cerebral oxygen delivery. The mechanisms considered reponsible are inhibition of calcium influx into vascular smooth muscle cells, thus relieving the vascular spasm originating from anoxia (7). Another mechanism involved is the inhibition of calcium influx into red blood cells, causing the erythrocyte deformability to remain intact (17). Studies on the impact of calcium channel 
Table 43. Fetal cardiovascular parameters

\begin{tabular}{|c|c|c|c|c|c|}
\hline Flunarizine group & Baseline & As & hyxiat & Post-1 & Post-2 \\
\hline FHR (beats/min) & $172 \pm$ & 194 & $\pm 22 *$ & $\pm 13 *$ & $\pm: 17^{*}$ \\
\hline $\mathrm{Pa}(\mathrm{mm} \mathrm{Hg})$ & $46.2 \pm 2.2$ & 45.5 & $\pm \quad 3.7$ & $44.7 \pm 3.4$ & 42.5 \\
\hline Pv $(\mathrm{mm} \mathrm{Hg})$ & $6.2 \pm$ & 5.5 & 1.5 & $6.0 \pm 1.6$ & 5.9 \\
\hline $\mathrm{Pa}-\mathrm{Pv}(\mathrm{mm} \mathrm{Hg})$ & $45.0 \pm$ & 39.1 & $\pm \quad 3.9$ & $41.0 \pm 4.1$ & 35.7 \\
\hline Control group & Baseline & \multicolumn{2}{|c|}{ Asphyxia } & Post-1 & Post -2 \\
\hline FHR (beats/min) & \pm 12 & 221 & $\pm 13^{*}$ & $\pm 12^{*}$ & $\pm 31:$ \\
\hline $\mathrm{Pa}(\mathrm{mm} \mathrm{Hg})$ & $51.6 \pm 2.5$ & 48.2 & \pm 3.8 & $48.2 \pm 3.7$ & $\pm \quad 3.4$ \\
\hline $\mathrm{Pv}(\mathrm{mm} \mathrm{Hg})$ & $4.5 \pm$ & 4.8 & 3.8 & $7.5 \pm$ & 6.7 \\
\hline $\mathrm{Pa}-\mathrm{P} v(\mathrm{~mm} \mathrm{Hg})$ & $47.2 \pm$ & 43.5 & 3.6 & $40.7 \pm$ & $\pm \quad 4.4$ \\
\hline
\end{tabular}

Values are expressed as mean \pm SEM. Asphyxia is at time $=60 \mathrm{~min}$, post -1 is at time $=90 \mathrm{~min}$. and post -2 is at time $=180 \mathrm{~min} . n=8$ for control group, $n=7$ for flunarizine group, except at post -2 when $n=7$ and $n=6$, respectively.

*: $p<0.05$ (asphyxia, post-1, or post-2 versus baseline; Friedman two-way ANOVA).

blockers on CBF and neurologic recovery after cerebral ischemia in adult dogs have yielded conflicting outcomes. Results varied from considerable benefits to total absence of improvement $(8,18,19)$. The second theory is that calcium channel blockers would directly reduce calcium entry into neurons, thereby enhancing resistance to injury. Flunarizine proved to be a potent blocker of low-threshold calcium channels (20). Maintaining low intracellular concentrations of calcium is an important modality in the prevention of cell death $(10,12)$. Van Reempts et al (21) observed a reduced infarct size after photochemically induced thrombosis in spontaneously hypertensive rats and postulated based on histologic findings that flunarizine might contribute to preservation of the integrity of endothelial cell membranes (reduction of platelet adhesion and vasogenic edema formation), of neuronal cell membranes (inhibition of calcium overload), and of glial cell membranes (prevention of cytotoxic edema formation). More recently, flunarizine enhanced neuronal survival in lumbar sensory ganglia from newborn rats after axotomy (22). The researchers suggested that this effect was caused by unknown intracellular acting mechanisms, distinct from blockade of voltage-dependent calcium channels.

Before considering the use of calcium channel blockers in the treatment of perinatal asphyxia, extensive animal research on the effects of these drugs on fetal brain circulation, metabolism, and function are needed (1). The present study not only focuses on the effect of flunarizine on the fetal regional CBF after asphyxia but also analyzes the effect on FHR and fetal systemic blood pressure. Flunarizine is a highly lipophylic substance, easily crossing the hlood-brain barrier. In humans it is used to treat neurologic disorders varying from migraine and vertigo to epilepsy (16). To mimic treatment in a clinical pathologic condition, we chose to start the infusion of flunarizine after a profound and prolonged period of asphyxia. 
Oxygen delivery to the brain depends on both the $\left[\mathrm{O}_{2}\right] \mathrm{a}$ and the regional $\mathrm{CBF}$. The $\mathrm{CBF}$ varies with gestational age. Baseline values in the present study correspond with those reported by others $(23,24)$. No differences in CBF changes between both groups, either in the baseline period or asphyxia period, or in the phase immediately after severe asphyxia during which flunarizine was adminis-

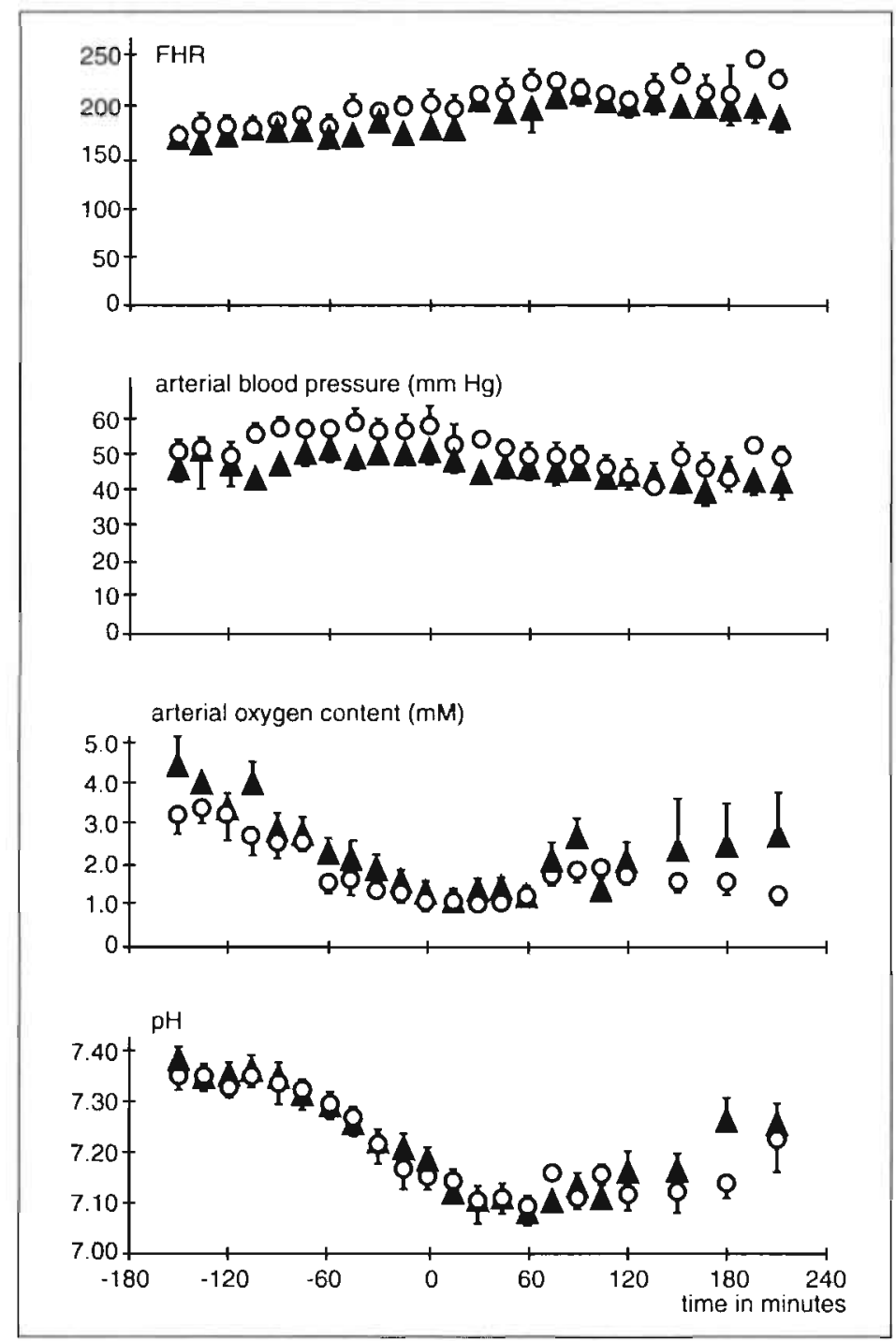

Figure 4.2. Time course of FHR, $\mathrm{Pa} .\left[\mathrm{O}_{2}\right] \mathrm{a}$, and $\mathrm{pH}$ (mean $\pm \mathrm{SEM}$ ). Time -180 to -120 $\mathrm{min}=$ baseline period; time -120 to $0 \mathrm{~min}=$ progressive reduction of uterine blood flow; time 0 to $60 \mathrm{~min}=1$ hour period of severe asphyxia; time 60 to $240 \mathrm{~min}=$ recovery period. Filled triangles represent the flunarizine-treated group, open circles represent the control group. 
tered, were observed. The $\left[\mathrm{O}_{2}\right] \mathrm{a}$ in both groups was comparable during baseline and asphyxia. Also, in the post asphyxial phase, the $\left[\mathrm{O}_{2}\right]$ a between groups was not statistically different. It can only be speculated that the nonsignificant slightiy higher $\left[\mathrm{O}_{2}\right] \mathrm{a}$ in the flunarizine-treated group might be caused by better brain functioning, improved myocardial performance, and placental perfusion, or by coincidence. At post-2, CBF in the control group is still elevated compared with baseline, whereas CBF has normalized in the flunarizine-treated group. Therefore, the net result of oxygen delivery is the same in both groups. The increased regional CBF in animals suffering from hypoxia or asphyxia is in agreement with literature (9).

Reduction of matemal uterine blood flow with a balloon occluder around the common internal iliac artery resulted in severe asphyxia in all animals. An immediate effect of occlusion was a transient bradycardia with arterial hypertension. These cardiovascular parameters soon stabilized, resulting after 1 hour of severe asphyxia in tachycardia and normal blood pressure in both groups. This is in agreement with data from others (24). The change from bradycardia to tachycardia and hypertension to normotension might be secondary to a sustained release of catecholamines (25), in combination with hypercapnia, which reduces vagal inhibition and thereby enhances sympathetic stimulation of the FHR (26). The degree and duration of asphyxia have their influence on cardiovascular reaction patterns $(27,28)$. One possible explanation for the final decompensation after severe asphyxia is hypoxic myocardial failure, which is accompanied by an elevation in central venous pressure and the development of hypotension (28). Cardiovascular reaction patterns were not influenced by the infusion of flunarizine, as can be seen from the FHR and Pa data in Figure 4.2. When asphyxia becomes too severe, oxygen delivery to vital organs can no longer be maintained (29). The ensuing anaerobic metabolism increases the amount of serum lactate in the fetus (28). In the present study, lactate concentrations increased to approximately $10 \mathrm{mM}$ during asphyxia and remained at this level at least 2 hours after the period of severe asphyxia. Although the $\left[\mathrm{O}_{2}\right]$ a failed to recover to baseline values and the acid-base state did not normalize, fetal cardiovascular function in the first 3 hours after asphyxia appeared to be adequate, as is suggested by a normal $\mathrm{Pa}$ and $\mathrm{Pv}$. Perfusion pressure (Pa-Pv) also remained unaltered during the experiment in both groups.

The mean fetal blood loss of approximately $28.5 \mathrm{~mL}$ per animal in the present study did not result in a decrease in fetal $\mathrm{Hb}$ levels or even in fetal anemia. This is in accordance with the study of Brace and Cheung (30) who removed an average of $120.3 \pm 5.1 \mathrm{~mL}$ of blood ( $30.8 \%$ of the initial blood volume) in a period of 2 hours in fetal lambs. Complete restitution of fetal blood occurred in only 3 hours, demonstrating that the dynamic fetal fluid system can accurately regulate its blood volume. Therefore, it is unlikely that the mortality, which was as high as $67 \%$ (10 of 15 animals) within the first 12 hours after the experiment, is caused by fetal hemorrhage resulting from the experimental protocol. The dead fetuses did 
not develop anemia before death. This strengthens the idea of ongoing pump failure during severe asphyxia, leading to insufficient placental perfusion, prolonged hypoxia, and progressive decompensation of both the metabolic and cardiovascular equilibrium. Most animals did not recover and died within 12 hours. Of the five animals completely recovering from asphyxia and surviving longer than 12 hours, four were treated with flunarizine. With these low numbers, only speculations can be made on protective properties of flunarizine. It also remains questionable to what extent fetal brain damage has contributed to the high percentage of early fetal denise.

In summary, the present data show that flunarizine, given after a period of severe asphyxia of 1 hour in preterm fetal lambs, does not influence regional CBF in the immediate post asphyxial period, and does not affect FHR, Pa, or Pv. Mortality after such a long period of asphyxia is high; the effect of flunarizine on survival remains to be elucidated.

It is concluded that a possible beneficial effect of flunarizine on the fetal brain after asphyxia cannot be ascribed to an altered CBF, to its effect on systemic $\mathrm{Pa}$ or $\mathrm{Pv}$, or to its influence on FHR. 


\section{References}

1. Espinoza MI, Parer JT 1991 Mechanisms of asphyxial brain damage, and possible pharmacologic interventions, in the fetus. Am J Obstet Gynecol 164:1582-1591

2. Vanhoutte PM, Paoletti R 1987 The WHO classification of calcium antagonists. Trends Pharmacol Sci 8:4-5

3. Silverstein FS, Buchanan K, Hudson C, Johnston MV 1986 Flunarizine limits hypoxia-ischemia induced morphologic injury in immature rat brain. Stroke 17:477482

4. Gunn AJ, Mydlar T, Bennet L. Faull RLM, Gorter S, Cook C, Johnston BM 1989 The neuroprotective actions of a calcium channel antagonist, flunarizine, in the infant rat. Pediatr Res 25:573-576

5. Van Reempts J, Borgers M, Van Dael L, Van Eyndhoven J, Van de Ven M 1983 Protection with flunarizine against hypoxic-ischemic damage of the rat cerebral cortex. A quantitative morphologic assessment. Arch Int Pharmacodyn Ther 262:7688

6. De Rijck M, Van Reempts J, Borgers M, Wauquier A, Janssen PAJ 1989 Photochemical stroke model: flunarizine prevents sensorimotor deficits after neocortical infarcts in rats. Stroke 20:1383-1390

7. Van Nueten JM, Van Beek J, Janssen PAJ 1978 Effect of flunarizine on calciuminduced responses of peripheral vascular smooth muscle. Arch Int Pharmacodyn Ther 232:42-52

8. Steen PA, Newberg LA, Milde JH, Michenfelder JD 1983 Nimodipine improves cerebral blood flow and neurologic recovery after complete cerebral ischemia in the dog. J Cereb Blood Flow Metab 3:38-43

9. Peeters LLH, Sheldon RE, Jones MD, Makowski EL, Meschia G 1979 Blood flow to fetal organs as a function of arterial oxygen content. Am J Obstet Gynecol 135:637 . 646

10. Farber JL 1981 The role of calcium in cell death. Life Sci 29:1289-1295

11. Katz AM, Reuter H 1979 Cellular calcium and cardiac cell death. Am J Cardiol $44: 188-190$

12. Siesjö BK 1981 Cell damage in the brain: a speculative synthesis. J Cereb Blood Flow Metab 1:155-185

13. de Haan HH, de Haan J, Van Belle H, Hasaart THM 1993 The effect of adenosine transport inhibition on cardiovascular function and survival after severe asphyxia in fetal lambs. Pediatr Res 33:185-189

14. Rudolph AM, Heymann MA 1967 The circulation of the fetus in utero. Circ Res $21: 163-184$

15. Todd PA, Benfield P 1989 Flunarizine. A reappraisal of its pharmacological properties and therapeutic use in neurological disorders. Drugs 38:481-499

16. Buckberg GD, Luck JC, Payne B, Hoffman JIE, Archie JP, Fixler DE 1971 Some sources of error in measuring regional blood flow with radioactive microspheres. $J$ Appl Physiol 31:598-604 
17. Van Nueten JM, Vanhoutte PM 1980 Improvement of tissue perfusion with inhibitors of calcium ion influx. Biochem Pharmacol 29:479-481

18. Newberg LA, Steen PA, Milde JH, Michenfelder JD 1984 Failure of flunarizine to improve cerebral blood flow or neurologic recovery in a canine model of complete cerebral ischemia. Stroke 15:666-671

19. Borgers M, Van Reempts J 1989 Effects of $\mathrm{Ca}^{2+}$-entry blockers on ischemic brain. J Neurosurg Anesth 1:368-374

20. Akaike N, Kostyuk PG, Osipchuk YV 1989 Dihydropyridine-sensitive low-threshold calcium channels in isolated rat hypothalamic neurones. J Physiol 412:181-195

21. Van Reempts J, Van Deuren B, Van de Ven M, Cornelissen F, Borgers M 1987 Flunarizine reduces cerebral infarct size after photochemically induced thrombosis in spontaneously hypertensive rats. Stroke 18:1113-1119

22. Rich KM, Hollowell JP 1990 Flunarizine protects neurons from death after axotomy or NGF deprivation. Science 248:1419-1421

23. Szymonowicz W, Walker AM, Cussen L, Cannata J, Yu VYH 1988 Developmental changes in regional cerebral blood flow in fetal and newborn lambs. Am J Physiol 254:H52-H58

24. Bocking AD, Gagnon R, White SE, Homan J, Milne KM, Richardson BS 1988 Circulatory responses to prolonged hypoxemia in fetal sheep. Am J Obstet Gynecol 159:1418-1424

25. Jones CT, Robinson RO 1975 Plasma catecholamines in foetal and adult sheep. J Physiol 248:15-33

26. Gu W, Jones CT, Parer JT 1985 Metabolic and cardiovascular effects on fetal sheep of sustained reduction of uterine blood flow. J Physiol 368:109-129

27. Block BS, Schlafer DH, Wentworth RA, Kreitzer LA, Nathanielsz PW 1990 Intrauterine asphyxia and the breakdown of physiologic circulatory compensation in fetal sheep. Am J Obstet Gynecol 162:1325-1331

28. Yaffe H, Parer JT, Block BS, Llanos AJ 1987 Cardiorespiratory responses to graded reductions of uterine blood flow in the sheep fetus. J Dev Physiol 9:325-336

29. Richardson BS, Rurak D, Patrick JE, Homan J, Carmichael L 1989 Cerebral oxidative metabolism during sustained hypoxaemia in fetal sheep. J Dev Physiol 11:37-43

30. Brace RA, Cheung CY 1986 Fetal cardiovascular and endocrine responses to prolonged fetal hemorrhage. Am J Physiol 251: R417-R424 


\section{Chapter 5}

\section{The effect of adenosine transport inhibition on cardiovascular function and survival after severe asphyxia in fetal lambs}

Harmen H. de Haan ${ }^{\text {a }}$, Jelte de Haan ${ }^{\text {a }}$, Herman Van Belle ${ }^{\text {b }}$ and Tom H.M. Hasaart ${ }^{\text {a }}$

From the Department of Obstetrics and Gynecology,

University Hospital, Maastricht, the Netherlands a, and the Department of Biochemistry,

Janssen Research Foundation, Beerse, Belgium ${ }^{\text {b }}$

Pediatric Research 1993; 33: 185-189 


\section{Abstract}

When the energy demand exceeds the energy supply, anaerobic metabolism takes over and the ATP catabolite adenosine is generated. Adenosine acts as a coronary vasodilator, thereby increasing the oxygen supply to the heart. Its potential, however, is poorly exploited due to extensive catabolism. R-75231 inhibits transport of adenosine into endothelial cells, where it is catabolized, resulting in an elevation of interstitial adenosine concentrations. In 14 fetal lambs, (3 to 5 days after surgery, gestational age $124.1 \pm 1.1$ day), seven fetuses were pretreated with $R-75231(0.1 \mathrm{mg} / \mathrm{kg}$ estimated fetal weight as a bolus injection in the inferior vena cava), whereas the other seven served as controls. After 1 hour of severe asphyxia, induced by restriction of uterine blood flow, those fetuses treated with $R-75231$ showed a faster normalization of aortal $\mathrm{pH}$ and, in contrast to the control group, did not develop tachycardia. The percentage increase in myocardial blood flow during asphyxia, measured with radioactive microspheres, was significantly higher in the R-75231-treated group compared to the control group (437 and $284 \%$, respectively). In the control group, only three fetuses recovered and survived, whereas in the $R-75231$ group all seven animals recovered after severe asphyxia. It is concluded that fetal lambs pretreated with $R-75231$ before the onset of severe asphyxia have an enhanced increase in myocardial blood flow during asphyxia, recover faster and survive longer. 


\section{Introduction}

It is well documented that lack of oxygen accelerates the catabolism of ATP in the myocardium, due to lack of rephosphorylation of ADP and AMP (1). This results in the formation of adenosine. Because of its many interesting pharmacological properties (coronary vasodilation, anti-adrenergic effects, inhibition of platelet and leukocyte activation) (2), the production of adenosine can be regarded as a natural defense system. After 2 hours of partial myocardial ischemia in dogs, ventricular function was improved by intracoronary administration of adenosine (3).

Extensive catabolism of adenosine in endothelial cells and the concomitant short half-life does not facilitate adenosine therapy (4). Continuous infusions of high doses of adenosine would be necessary, giving rise to systemic vasodilation and unwanted side effects in various organ systems. To avoid these problems, we pretreated fetal lambs with R-75231, a potent and specific adenosine transport inhibiting drug with unique pharmacokinetic properties (5). During asphyxia, myocardial workload increases and adenosine is released. Adenosine transport inhibition has two major advantages. First, R-75231 will show an effect only if, and as long as, adenosine is produced; and second, the action will be restricted only to the area where adenosine is produced. Thus, cardiac effects of adenosine are enhanced, whereas side effects in other organs are avoided.

We hypothesized that an increased myocardial concentration of adenosine during severe asphyxia leads to an enhanced MBF, better cardiac functioning during and after asphyxia, and an improvement in fetal survival. To test this hypothesis we studied fetal lambs, pretreated with R-75231, during and after asphyxia. We measured cardiovascular parameters as FHR, Pa, and $\mathrm{P} v$ and MBF.

\section{Material and methods}

\section{Surgery}

Surgery was performed in 14 Dutch Texel sheep of known mating dates between 110 and 124 days gestation (mean \pm SEM $=120.5 \pm 1.0$ days, term $=147$ days).

General anesthesia was induced with intravenous pentobarbital and maintained with $1 \%$ halothane in a $2: 1$ mixture of nitrous oxide and oxygen. Before surgery the ewes received intravenously $1 \mathrm{~g}$ of ampicillin. Under sterile conditions, a paramedian abdominal incision was made, and an inflatable balloon occluder was placed around the maternal common internal iliac artery. Fetal instrumentation involved insertion of catheters in the axillary and femoral artery, the tips advanced to the level of the brachiocephalic trunk and descending aorta, respectively. In addition, catheters were placed in the femoral vein with the tip advanced into the inferior vena cava, the trachea and the amniotic cavity. Fine stainless steel wires (Cooner Sales Co., Chatsworth, California, USA) were placed over the dura of the parietal cortex for recording of the fetal ECoG. A polyvinyl 
catheter was placed in the spinal cisterne to obtain CSF. Electrodes were subcutaneously implanted at the level of the cardiac apex and at both forelegs for recording of the fetal ECG. Catheters and wires were exteriorized to the ewe's flank.

Ewes were housed in individual cages with free access to food and water and were allowed to recover from surgery for at least 3 days before the experiments were started. A continuous slow infusion ( $1 \mathrm{~mL} / \mathrm{hour})$ of heparin in saline $(10 \mathrm{U} / \mathrm{mL})$ was used to maintain patency of fetal arterial and venous catheters. Guidelines for care and use of animals as approved by the local Animal Medical Ethics Committee were followed.

\section{Measurements}

$\mathrm{Pa}, \mathrm{Pv}$, tracheal pressure, and amniotic pressure were determined with the zero point at the level of the ewe's spine. These signals, together with the fetal ECG, the fetal ECoG and the FHR, derived from the pulsatile signal of the femoral artery, were fed into bioelectric amplifiers (Hewlett Packard 8800 series, Andover, Mass., USA), displayed on a monitor, recorded on an eight-channel strip chart recorder, stored on magnetic tape, and digitized and analyzed with a computer.

MBF was measured with radioactive microspheres with a diameter of 15 $\mu \mathrm{m}$. In random order, one out of four available microspheres $\left({ }^{95} \mathrm{Nb},{ }^{103} \mathrm{Ru},{ }^{113} \mathrm{Sn}\right.$, and ${ }^{141} \mathrm{Ce}$ ) was injected. Aggregation of the microspheres was prevented by adding $0.05 \%$ Tween 80 to the injection medium. After homogenization in an ultrasonic waterbath at $39^{\circ} \mathrm{C}$ (Bransonic 5200, Soest, the Netherlands) for 20 minutes, approximately $0.5 \times 10^{6}$ microspheres were stirred on a vortex agitator and infused over a period of 1 minute into the inferior vena cava (6). Reference sampling (1.80 mL/min) (Harvard Apparatus Ltd., Kent, England) was started from the brachiocephalic arch 30 seconds before infusion, continued during infusion, and stopped 1 minute after infusion.

Blood gas values and $\mathrm{pH}$ from the fetal aortic arch were measured with an automated analyzer (AVL. Radiometer, Copenhagen, Denmark) and corrected for $39^{\circ} \mathrm{C}$. The percentage of saturation of $\mathrm{Hb}$ was measured (OSM2 Hemoximeter, Radiometer). The $\left[\mathrm{O}_{2}\right]$ a was calculated as follows: $\left[\mathrm{O}_{2}\right] \mathrm{a}(\mathrm{mM})=\mathrm{Hb}$ concentration $(\mathrm{mM}) \times \mathrm{Hb}$ oxygen saturation $(\% / 100)$.

Immediately after the microsphere injection, $2 \mathrm{~mL}$ of blood were with drawn from the axillary artery and centrifuged ( 3 minutes at 13,000 revolutions/min). Serum was frozen in liquid nitrogen and stored at $-73^{\circ} \mathrm{C}$. After all experiments had ended, serum lactate concentrations were determined in these samples.

\section{Experiments}

Gestational age during experiments varied between 113 and 129 days (mean $\pm \mathrm{SEM}=124.1 \pm 1.1$ days). Baseline values for $\mathrm{FHR}, \mathrm{Pa}$ and $\mathrm{Pv}$ were 
obtained during a control period of at least 2 hours. Fetal acid-base balance was analyzed every 15 minutes.

During the haseline period, MBF was determined. Fifteen minutes thereaticr seven of the 14 lambs received an intravenous bolus of R-75231 (2(aminocarbonyl)-N-(4-amino-2,6-dichlorophenyl)-4-[5,5-bis(4-fluorophenyl)pentyl]-1-piperazineacetamine) in a dose of $0.1 \mathrm{mg} / \mathrm{kg}$ estimated fetal weight. Estimation of fetal weight was performed during instrumentation.

Severe fetal asphyxia was induced by stepwise inflation of the balloon occluder around the maternal common internal iliac artery. During the occlusion period, every 15 minutes the aortic fetal acid-base balance was determined. To maintain the fetus in a stable hemodynamic condition, uterine blood flow was gradually reduced over a period of 60 to 90 minutes, until fetal $\left[\mathrm{O}_{2}\right]$ a reached a value of approximately $30 \%$ of baseline level and/or the fetal $\mathrm{pH}$ had decreased to a value less than 7.15 . This condition was considered the start of fetal asphyxia and occlusion was kept at the same level for 1 hour. At the end of this period, MBF was remeasured. Following, the uterine blood flow obstruction was discontinued by emptying the balloon occluder. MBF was determined again at 30 and 120 minutes after release of the occluder. Fetal recovery was monitored, and when the fetal condition did not improve 3 to 5 hours after asphyxia, the fetal lambs were disconnected from registration and fetal $\mathrm{Pa}$ was checked regularly to determine survival interval. During the disconnected period, no blood gas analysis was performed. After 3 days of survival a relaparotomy was performed. Under general anesthesia, fetal blood was replaced in vivo by Karnovsky's fixative solution (a mixture of $2.5 \%$ glutaraldehyde and $2.0 \%$ formaldehyde) to allow further histologic evaluation of the fetal brain. Subsequently, fetuses were removed and weighed, and correct catheter placement was confirmed at autopsy after 3 days or earlier in case of fetal demise.

\section{Calculations and data analysis}

FHR, Pa, and Pv, corrected for amniotic pressure, were averaged over 10 seconds periods by computer.

For reasons of accuracy, MBF was calculated from the mean flow of three samples out of left ventricular base, middle, and apex of the fetal heart. The samples were weighed $( \pm 1 \mathrm{~g}$ ), put into test tubes, and additionally preserved in Karnovsky's fixative solution. Radioactivity in tissue and blood samples was measured with a gamma scintillation counter and sample changer system (analyzer model 45, Molsgaard Medical, Horsholm, Denmark). MBF was calculated with an ND680 programmable analyzer/computer system (Nuclear Data GmbH, Frankfurt, Germany). All data are expressed as mean \pm SEM. For statistical analysis within groups the Wilcoxon matched-pairs signed-ranks test was used, whereas differences between the R-75231-treated and the control group were tested with the two-tailed Mann-Whitney $U$ test. A p-value $<0.05$ was considered significant. 
Linear regression analysis was performed for FHR and $\mathrm{pH}$ in the post occlusion period. Slopes of the lines of individual animals were compared by means of a two-tailed Mann-Whitney $\mathrm{U}$ test to determine differences between groups. The Log rank-test (7) was used to compare survival in both groups.

\section{Results}

In Figure 5.1 the time course of mean $\left[\mathrm{O}_{2}\right] \mathrm{a}, \mathrm{pH}$, and $\mathrm{BE}$ for hoth experimental groups is depicted. The magnitude of metabolic acidosis and BE decrease is comparable in both groups, but a significant difference existed in $\left|\mathrm{O}_{2}\right| \mathrm{a}$ during the period of severe asphyxia (time 0 to $60 \mathrm{~min}$ ). In the R-75231-treated group the $\left[\mathrm{O}_{2}\right]$ a remained higher. The $\mathrm{pH}$ after 1 hour of severe asphyxia, however, was 6.99 and 7.06 for the R-75231-treated and the control group, respectively $(p=0.08)$. Values below $-17.5 \mathrm{mM}$ were reached for the $\mathrm{BE}$ in both experimental groups. To analyze the speed of recovery, mean linear regression lines for $\mathrm{pH}$ against change in time in both groups were calculated over the post occlusion period, beginning at time $=60 \mathrm{~min}$, when the occluder was released. Comparison of the 14 individual slopes of these regression lines (mean slope 1.88 \pm 0.36 versus $0.76 \pm 0.39$, whereas $r=0.87$ and 0.89 , both slopes and $r$-value for the R-75231-treated and the control group, respectively) of these lines with a twotailed Mann-Whitney U test, showed that the $\mathrm{pH}$ in the R-75231-treated group normalized faster $(p<0.05)$ toward baseline levels compared with the control group.

Time course of FHR, Pa, and Pv is shown in Figure 5.2. Administration of R-75231 before the onset of occlusion did not induce any changes in either FHR, $\mathrm{Pa}$, or $\mathrm{Pv}$ in six out of seven treated animals. In one animal a transient bradycardia (from 145 to 110 beats/min) of 15 seconds was observed, without simultaneous changes in $\mathrm{Pa}$ or $\mathrm{Pv}$. In the post occlusion phase, starting at time $=60 \mathrm{~min}$, linear regression lines for FHR against change in time in both groups were calculated. Comparison of the slopes of these lines (mean slope is $-0.15 \pm 0.12$ versus $0.13 \pm$ 0.10 , whereas $r=0.53$ and 0.62 , slopes and $r$-values for the R-75231-treated and the control group, respectively) with a two-tailed Mann-Whitney $U$ test showed the development of a tachycardia (recovery period compared with baseline) in the control group, versus the absence of this tachycardia in the R-75231-treated group $(\mathrm{p}<0.05)$. During the occlusion (approximately from time $=-75$ to $60 \mathrm{~min}) \mathrm{Pa}$ in the control group was elevated compared with baseline levels (Wilcoxon matchedpairs signed-ranks test, $\mathrm{p}<0.05$ ), whereas $\mathrm{Pa}$ remained unchanged in the R-75231treated group. At two moments in the occlusion period (time $=-75$ and $-45 \mathrm{~min}$ ) differences between groups reached signilicance. Pv remained unaltered in both groups during the entire experiment.

MBF was measured at four conditions in the experiment. At these moments, serum lactate levels were determined as well. The individual MBF data of all 14 animals are shown in Figure 5.3, whereas the means and percentage of increase are 


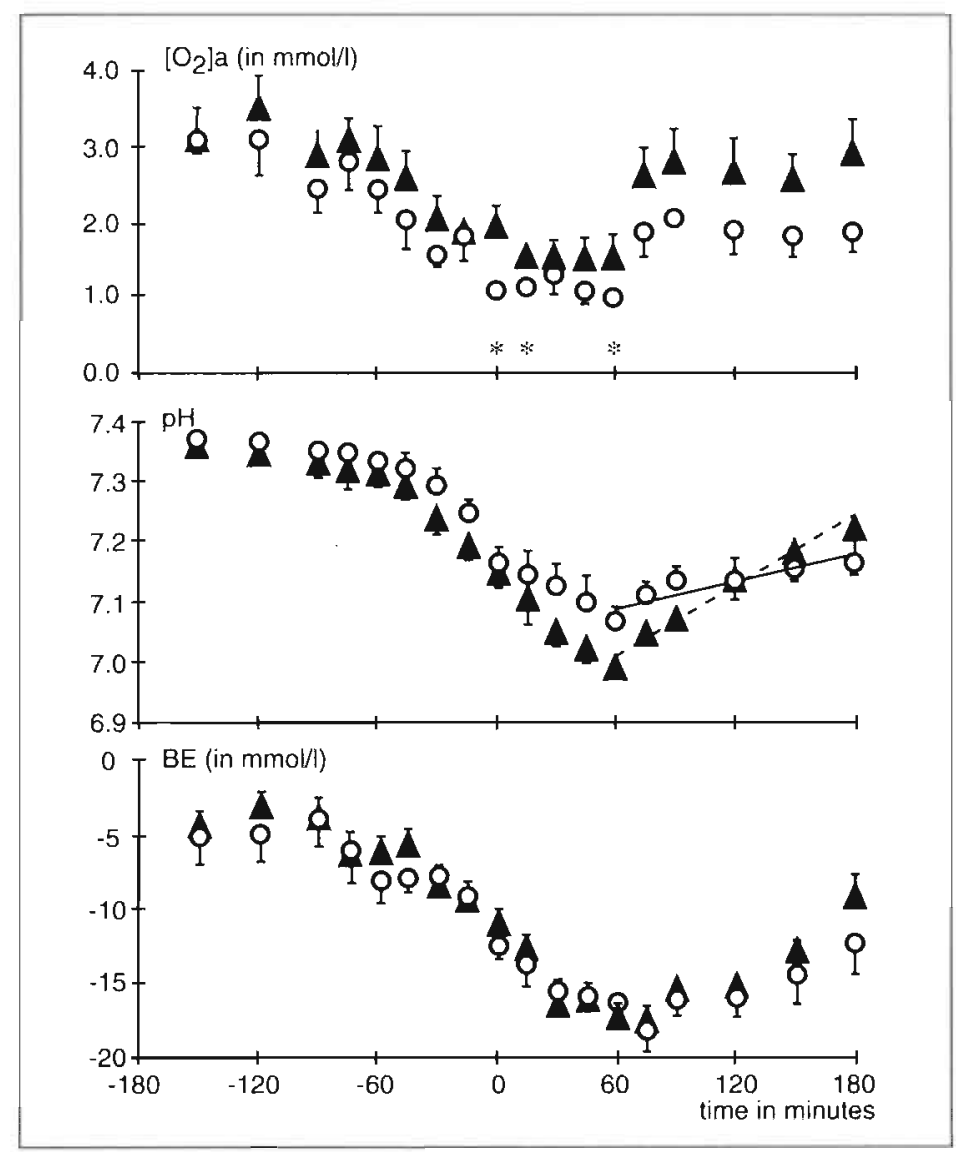

Figure 5.1. Time course of $\left[\mathrm{O}_{2}\right] \mathrm{a}, \mathrm{pH}$ and $\mathrm{BE}$ (upper, middle and lower panel, respectively), expressed as mean \pm SEM. Filled triangles represent the R-7523I-treated group, open circles the control group. Mean linear regression lines for the R-75231-treated group (dashed line) and the control group (solid line) in the post occlusion phase are drawn for $\mathrm{pH}$ against change in time. The slopes of these lines are significantly different (MannWhitney $U$ test, $\mathrm{p}<0.05$ ). Time -180 to $-100 \mathrm{~min}=$ haseline period; time -100 to $0 \mathrm{~min}=$ progressive reduction of uterine blood flow; time 0 to $60 \mathrm{~min}=1$ hour of severe asphyxia; time 60 to $180 \mathrm{~min}=$ post occlusion period. R-75231 was administered approximately at time $=-120 \mathrm{~min}$. Differences between groups (two-tailed Mann-Whitney U test, $\mathrm{p}<0.05$ ) are indicated with an asterisk. 


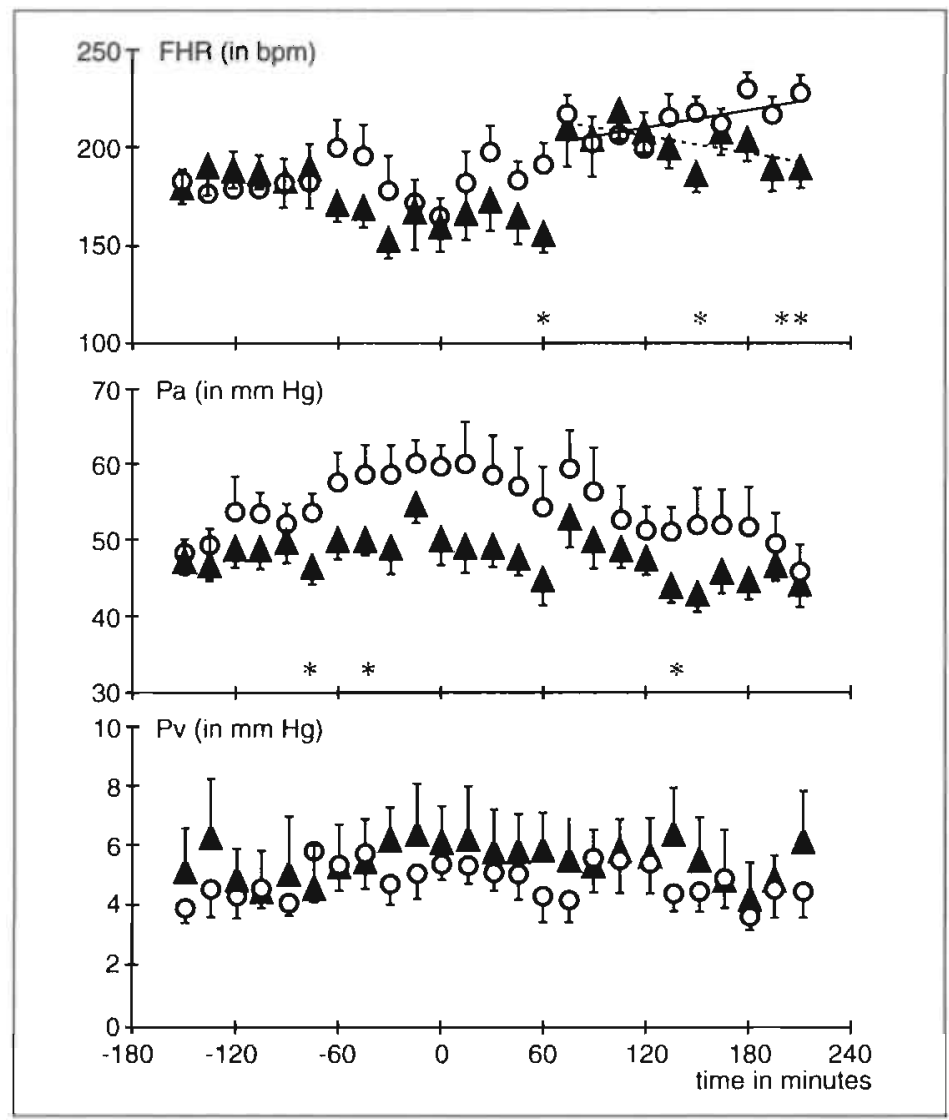

Figure 5.2. Time course of FHR, Pa and Pv (upper, middle and lower panel, respectively), expressed as mean \pm SEM. Filled triangles represent the R-75231-treated group, open circles the control group. Mean linear regression lines for the R-75231-treated group (dashed line) and the control group (solid line) in the post occlusion phase are drawn for $\mathrm{pH}$ against change in time. The slopes of these lines are significantly different (MannWhitney $U$ test, $\mathrm{p}<0.05$ ). Time -180 to $-100 \mathrm{~min}=$ baseline period; time -100 to $0 \mathrm{~min}=$ progressive reduction of uterine blood flow; time 0 to $60 \mathrm{~min}=1$ hour period of severe asphyxia; time 60 to $180 \mathrm{~min}=$ post occlusion period. R-75231 was administered approximately at time $=-120 \mathrm{~min}$. Differences between groups (two-tailed Mann-Whitney $\mathrm{U}$ test, $\mathrm{p}<0.05$ ) are indicated with an asterisk.

summarized in Table 5.1. During asphyxia, the percentage of increases in MBF was significantly higher in the R-75231-treated group than in the control group $(\mathrm{p}<0.05)$. In contrast $t o$ the $\mathrm{R}-75231$ treated group, MBF remained significantly increased $(p<0.05)$ in the control group at 120 minutes after release of the occluder. 


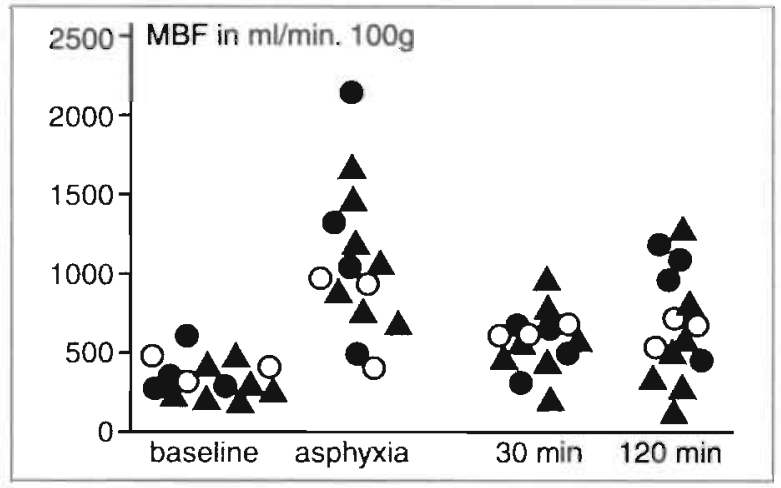

Figure 5.3. MBF of all 14 animals at four moments in the experiment (baseline, after 1 hour of severe asphyxia, and 30 and 120 min after release of the occluder). Filled triangles represent the R-75231-treated group, filled circles the control group without recovery $(n=4)$, and open circles the control group with recovery $(n=3)$.

Table 5.1. Fetal MBF and fetal lactate kevels

\begin{tabular}{|c|c|c|c|c|c|}
\hline R-75231 group & Baseline & Asphyxia & 30 minutes & \multicolumn{2}{|c|}{120 minutes } \\
\hline $\operatorname{MBF}\left(\mathrm{mL} \cdot \mathrm{min}^{-1} .100 \mathrm{~g}^{-1}\right)$ & \pm 50 & $1029 \pm 210^{\circ}$ & $518 \pm 89^{*}$ & 500 & \pm 175 \\
\hline MBF ( $\%$ of baseline) & 100 & $437 \pm 40 * \#$ & $\pm 57^{*}$ & 188 & \pm 50 \\
\hline lactate $(\mathrm{mM})$ & $1.8 \pm$ & $14.7 \pm$ & $14.4 \pm$ & 11.5 & $0.7^{*}$ \\
\hline Control group & Baseline & Asphyxia & 30 minutes & \multicolumn{2}{|c|}{120 minutes } \\
\hline $\operatorname{MBF}\left(\mathrm{mL} \min ^{-1} .100 \mathrm{~g}^{-1}\right)$ & \pm 44 & $\pm 225^{*}$ & $\pm 50^{\circ}$ & 750 & $\pm 120^{*}$ \\
\hline MBF ( $\%$ of baseline) & 100 & $60 * \#$ & $\pm 20^{*}$ & 223 & $\pm 32 *$ \\
\hline lactate (mM) & $1.8 \pm$ & $12.6 \pm$ & 12.0 & 12.8 & $1.8^{*}$ \\
\hline
\end{tabular}

Values are expressed as mean \pm SEM, $n=7$ for both groups. $R-75231$ is administered after baseline measuremen MBF was determined after I hour severe asphyxia and 30 and $120 \mathrm{~min}$ after release of the occluder.

: $p<0.05$ (asphyxia, 30 or 120 min versus baseline. Wilcoxon matched-pairs signed-ranks test)

\#:p<0.05 ( $R-7523$ I group versus control group. 2-tailed Mann-Whitney U test)

Table 5.2 summarizes the survival interval of all individual animals and the cause of fetal death. All animals of the treated group recovered well after asphyxia. Unfortunately, one ewe bit a fetal arterial catheter and the lamb bled to death 30 hours after asphyxia. From a twin gestation, the instrumented (and treated) animal recovered, but a second (and untreated) lamb was not monitored. The treated lamb recovered well, but died during parturition 22 hours after the experiment. When the lambs were born, it was clear that the other lamb had died much earlier (probably during the experiment). This intrauterine death may have been the cause of preterm labor. Animals surviving longer then 72 hours were killed for cerebral histology. Because of a logistical problem in the laboratory, one 
animal out of the control group was killed after only 24 hours. Survival in the R75231 treated group was better than in the control group (Log rank-test, $\mathrm{p}<0.05$ ). In this test, a correction has been made for the three animals described above.

Table 5.2. Fetal survival (in hours) and cause of fetal death for both experimental groups

\begin{tabular}{|c|c|c|}
\hline $\begin{array}{l}\text { animal- } \\
\text { number }\end{array}$ & $\begin{array}{l}\text { survival- } \\
\text { interval }\end{array}$ & $\begin{array}{l}\text { cause of fetal death } \\
\text { (R-75231-group) }\end{array}$ \\
\hline 1. & 72 & killed for histology \\
\hline 2. & 72 & killed for histology \\
\hline 3. & 72 & killed for histology \\
\hline 4. & \pm 30 & $\begin{array}{l}\text { good fetal recovery, but catheter } \\
\text { accident, fetus bled to death }\end{array}$ \\
\hline 5. & 22 & $\begin{array}{l}\text { ewe in labor, fetus died during } \\
\text { parturition }\end{array}$ \\
\hline 6. & 72 & killed for histology \\
\hline 7. & 72 & killed for histology \\
\hline $\begin{array}{l}\text { animal- } \\
\text { number }\end{array}$ & $\begin{array}{l}\text { Survival- } \\
\text { interval }\end{array}$ & cause of fetal death (control group) \\
\hline 1. & 5 & no recovery after asphyxia \\
\hline 2. & 5 & no recovery after asphyxia \\
\hline 3. & 24 & killed for histology \\
\hline 4. & 3 & no recovery after asphyxia \\
\hline 5. & 72 & killed for histology \\
\hline 6. & 72 & killed for histology \\
\hline 7 & 20 & no recovery atter asphyxia \\
\hline
\end{tabular}

\section{Discussion}

Depletion of nucleotides has been regarded as a major cause of irreversible damage and malfunctioning of the heart (8). High concentrations of adenosine have been documented to protect against the damage from myocardial ischemia in isolated hearts from rats (9) and rabbits (10). Most convincing evidence for cardioprotection however, has been gathered in a series of experiments in closed-chest dogs, in which adenosine has been infused in the coronary artery during the $1^{\text {st }}$ hour of reperfusion after periods of regional ischemia lasting 40 minutes (11), 90 minutes (12), 2 hours (3) or 3 hours (13). When compared with control animals, adenosine treated dogs had a much better functional recovery and a considerable reduction in infarct size. The benefit from adenosine was lost when the ischemic period was extended to 3 hours. This 
limitation may be due to the extensive catabolism of adenosine in endothelial cells and the rapid washout during reperfusion (4). Nucleoside transport inhibitors prevent the uptake of adenosine into endothelial cells. In this way, deamination is inhibited, leading to elevated interstitial adenosine levels. This mechanism was demonstrated after pretreatment with the nucleoside transport inhibitor mioflazine (14), and recent pharmacologic studies on R-75231 were even inore promising (5). R-75231 has recently been proposed as a highly effective concept for long-term preservation of donor hearts (15).

In the present study, restriction of uterine blood flow resulted in an increase of fetal $\mathrm{Pa}$ compared with baseline values (Wilcoxon matched-pairs signed-ranks test, $\mathrm{p}<0.05$ ) in the control group (Figure 5.2). The absence of this hypertension in the R-75231-treated group, and the significant differences between both groups (at time $=-45,-75$ and $135 \mathrm{~min}$ ) may be explained by the vasodilatory effect of adenosine in fetal sheep (16). Levels of adenosine are still expected to be elevated during the post occlusion phase, as $\mathrm{R}-75231$ has a long duration of action (4). The differences between groups in FHR (at time= 150, 195 and 210 min) may therefore be caused by the negative chronotropic activity of adenosine (17), or by inhibition of the tachycardic effect of catecholamines (18). On the other hand, these FHR differences can also be explained by a better oxygenation and higher $\mathrm{pH}$ in the $\mathrm{R}-75231$-treated group, leading to normalization of myocardial performance.

During baseline measurements, MBF varies considerably between animals. This is in agreement with the literature (19,20,21). MBF was measured at the peak of asphyxia, at time $=60 \mathrm{~min}$. The $\left[\mathrm{O}_{2}\right] \mathrm{a}$ at this moment was significantly lower in the control group compared with the R-75231-trealed group. Oxygen delivery to heart, brain and adrenal glands is maintained by an increase in MBF when $\left[\mathrm{O}_{2}\right]$ a decreases (19). Therefore, we expected the increase in $\mathrm{MBF}$ in the control group, i.e., the group with the lowest $\left[\mathrm{O}_{2}\right] \mathrm{a}$, to be larger than the increase in the R-75231-treated group. Although the absolute values of MBF were very similar in both groups during asphyxia, the percent increase in MBF was significantly higher in the R-75231 treated group (Table 5.1). As is shown in Figure 5.3 , these means of approximately $1,000 \mathrm{~mL} \cdot \mathrm{min}^{-1} .100 \mathrm{~g}^{-1}$ do not equal the maximum coronary blood flow that can be reached. The larger percentage of increases in MBF in the R-75231-treated group may very well be explained by the coronary vasodilative effect of adenosine (22). In the post asphyxial period, an enlarged diameter of vessels may allow passage of microemboli, originating from hypoperfused tissues during asphyxia (23). and, as a result, coronary microembolization can be prevented. During the post occlusion period MBF decreased in both groups compared with the asphyxial period. After 120 minutes in the post occlusion period $\mathrm{MBF}$ in the control group remained elevated compared with baseline, whereas MBF in the treated group was normalizing and not elevated compared to baseline. We suggest that this difference is explained by an impaired 
oxygenation in the control group during this phase (mean $\left[\mathrm{O}_{2}\right] \mathrm{a} \pm \mathrm{SEM}$ is $2.91 \pm$ 0.45 and $1.87 \pm 0.30$ for the R-75231-treated and the control group, respectively, Mann-Whitney $U$ test, $p<0.05$ ). Three out of four non-survivors in the control group have an augmented MBF (as can be seen in Figure 5.3), thus elevating mean MBF considerably.

Physiologic circulatory compensation during asphyxia, causing a preferential redistribution of blood, is avililable for a limited time only (24). Considering the magnitude and duration of asphyxia in the present study, inadequate recovery of four out of seven animals (Table 5.2) in the control group in the first 24 hours after asphyxia is not surprising. A plausible explanation for this mortality is cardiovascular failure. After severe asphyxia, a transient tachycardia precedes progressive hypotension and death.

We suggest that pretreatment with the adenosine transport inhibiting drug R-75231 leads to an enhanced increase in MBF during severe fetal asphyxia. This leads to better myocardial functioning after asphyxia, indicated by a faster normalization of $\mathrm{pH}$ and an absence of fetal tachycardia in the post occlusion period. Finally, this results in better survival.

As summarized elsewhere (5), nucleoside transport inhibition has been shown to be cardioprotective in a variety of experimental models and in different species. Because of the high specificity of nucleoside transport inhibition, its effects can be assumed to be solely due to the prolonged presence of adenosine within the area where it is produced. In view of its many known activities (coronary vasodilation $=$ increased blood supply; anti adrenergic $=$ lower demand; calcium-antagonist= afterload reduction; anti arthythmic; inhibition of platelet aggregation= no thrombosis; inhibition of leukocyte activation= no damage from radicals or proteases), adenosine can be regarded as a multipurpose drug, which can tackle the many problems arising during myocardial hypoxemia and reperfusion. From the present experiment, it is not possible to define which of the activities of adenosine is playing a major role. It is reasonable to assume that all of them, acting in concert, may contribute to the benefit observed.

In summary, pretreatment with the adenosine transport inhibiting drug R752.31 resulted in faster recovery and better survival after severe fetal asphyxia. Enhancement of the increase in MBF during asphyxia probably is one of the explanatory mechanisms. The actual working mechanism of adenosine transport inhibition during severe asphyxia in fetal lambs remains to be elucidated. 


\section{References}

I. Jennings RB, Reimer KA, Hill ML, Mayer SE 1981 Total ischemia in dog hearts, in vitro. 1. Comparison of high energy phosphate production, utilization, and depletion, and of adenine nucleotide catabolism in total ischemia in vitro vs. severe ischemia in vivo. Circ Res 49:892-900

2. Van Belle H 1985 Myocardial purines during ischemia, reperfusion and pharmacological protection. Mol Physiol 8:615-630

3. Babbitt DG, Virmani R, Forman MB 1989 Intracoronary adenosine administred after reperfusion limits vascular injury after prolonged ischemia in the canine model. Circulation 80: 1388-1399

4. Van Belle H, Goossens F, Wynants J 1987 Formation and release of purine catabolites during hypoperfusion, anoxia, and ischemia. Am J Physiol 252:H886-H893

5. Van Belle H, Janssen PAJ 1991 Comparative pharmacology of nucleoside transport inhibitors. Nucleosides Nucleotides 10:975-982

6. Rudolph AM, Heymann MA 1967 The circulation of the fetus in utero. Circ Res 21:163-184

7. Pocock SJ 1983 Clinical trials. a practical approach. John Wiley \& sons, Chichester, New York, p.224

8. Swain JL, Sabina RL, McHale PA, Greenfield JC, Holmes EW 1982 Prolonged myocardial nuclcotide depletion after brief ischemia in the open-chest dog. Am J Physiol 242:H818-H826

9. Ledingham S, Katayama O, Lachno D, Patel N, Yacoub M 1990 Beneficial effect of adenosine during reperfusion following prolonged cardioplegic arrest. Cardiovasc Res 24:247-253

10. Bolling SF, Bies LE, Bove EL, Gallagher KP 1990 Augmenting intracellular adenosine improvs myocardial recovery. J Thorac Cardiovasc Surg 99:469-474

11. Velasco CE, Turner M, Cobb MA, Virmani R, Forman MB 1991 Myocardial reperfusion injury in the canine model after $40 \mathrm{~min}$ of ischemia: Effect of intracoronary adenosine. Am Heart J 122:1561-1570

12. Pitarys CJ, Virmani R, Vildibill HD, Jackson EK. Forman MB 1991 Reduction of myocardial reperfusion injury by intravenous adenosine administered during the early reperfusion period. Circulation 83:237-247

13. Babbitt DG, Virmani R, Vildibill HD, Norton ED. Forman MB 1990 Intracoronary adenosine administration during reperfusion following 3 hours of ischemia: effects on infarct size, ventricular function, and regional myocardial blood flow. Am Heart J 120:808-818

14. Van Belle H, Xhonneux R, Flameng W, Wijnants J 1986 Oral pretreatment with mioflazine completely changes the pattern and remarkably prolongs the accumulation of nucleosides in ischemic and reperfused myocardium. Basic Res Cardiol 81:407-416

15. Flameng W. Sukehiro S, Möllhoff T, Van Belle H, Janssen PAJ 1992 A new concept of long-term donor heart preservation: nucleoside transport inhibition. J Heart and Lung Transplant 10:990-998 
16. Reid DL̃, Davidson SR, Phernetton TM, Rankin JHG 1990 Adenosine causes a biphasic response in the ovine fetal placental vasculature. J Dev Physiol 13:23724017.

Clemo HF, Belardinelli L 1986 Effect of adenosine on atrioventricular conduction II: Modulation of atrioventricular node transmission by adenosine in hypoxic isolated guinea pig hearts. Circ Res 59:437-446

18. Böhm M, Brückner R, Hackbarth I, Haubitz B, Linhart R, Meyer W, Schmidt B, Schmizz W, Scholz H 1984 Adenosine inhibition of catecholamine induced increase of force of contraction in guinea-pig atrial and ventricular heart preparations. Evidence against a cyclic AMP- and cyclic GMP-dependent effect. J Pharmacol Exp Ther 230:483-492

19. Peeters LLH, Sheldon RE, Jones MD, Makowski EL, Meschia G 1979 Blood flow to fetal organs as a function of arterial oxygen content. Am J Obstet Gynecol 135:637646

20. Bocking AD, Gagnon R, White SE, Homan J, Milne KM, Richardson BS 1988 Circulatory responses to prolonged hypoxemia in fetal sheep. Am J Obstet Gynecol 159:1418-1424

21. Reid DL, Parer JT, Williams K, Darr D, Phernetton TM, Rankin JHG J99 I Effects of severe reduction in maternal placental blood flow on blond flow distribution in the sheep fetus. J Devel Physiol 15:183-188

22. Berne RM 1980 The role of adenosine in the regulation of coronary blood flow. Circ Res 47:807-813

23. Hori M, Tamai J, Kitakaze M, Iwakura K, Gotoh K, Iwai K, Koretsune Y, Kagiya T, Kitabatake A, Kamada T 1989 Adenosine-induced hyperemia attenuates myocardial ischemia in coronary microembolization in dogs. Am J Physiol 257:H244-H251

24. Block BS, Schlafer DH, Wentworth RA, Kreitzer LA, Nathanielsz PW 1990 Intrauterine asphyxia and the breakdown of physiologic circulatory compensation in fetal sheep. Am J Obstet Gynecol 162:1325-1331 


\section{Chapter 6}

\section{Effects of asphyxia on the fetal lamb brain}

Harmen H. de Haan ${ }^{\text {, }}$, Jos L.H. Van Reempts ${ }^{\text {, }}$, Johan S.H. Vles ${ }^{c}$, Jelte de Haan ${ }^{\text {a }}$ and Tom H.M. Hasaart ${ }^{\text {a }}$

From the Departments of Obstetrics and Gynecology a and Child Neurology ${ }^{c}$, University Hospital, Maastricht, the Netherlands, and the Department of Life Sciences, Laboratory of Neuropathology, Janssen Research Foundation, Beerse, Belgium ${ }^{b}$

American Journal of Obstetrics and Gynecology 1993; 169: 1493-1501 


\section{Abstract}

The purpose was to study the effect of fetal asphyxia on the release of hypoxanthine and xanthine in cerebrospinal fluid (CSF) and on brain histologic characteristics. Therefore, in seven fetal lambs (3 to 5 days after surgery, gestational age $124.3 \pm 2.6$ days) asphyxia was induced by restriction of uterine blood flow. Fetal pH and base excess were reduced to $6.99 \pm 0.02$ and $-17.6 \pm 0.9$ $m M$, respectively. Cerebral blood flow increased during asphyxia and returned to normal in the recovery phase. Maximum concentrations of CSF hypoxanthine and CSF xanthine were reached in the normoxemic recovery phase. This high level of substrates during normoxemia facilitates oxygen derived free radical formation and may thus aggravate post-asphyxial brain damage. Histologic evaluation of the brain 3 days after the insult showed a variable degree of edema. Coagulative neuronal changes, characteristic of irreversible cell death, were only occasionally detected. These changes were most obvious in the Purkinje cells of the cerebellum. It was concluded that fetal asphyxia induced by uterine blood flow restriction is associated with high levels of CSF hypoxanthine and CSF xanthine in the recovery phase. Microscopically detectable brain damage, although not extensive, is mainly located in the cerebellum. 


\section{Introduction}

Fetal distress as a result of progressive fetal asphyxia can, if not corrected or circumvented, result in decompensation of physiologic responses and lead to permanent tissue injury or death (1). At the level of the central nervous system this damage becomes clinically apparent in seizures, hypotonia, and motor- and cognitive deficits $(2,3)$.

Several experimental setups have been used to investigate brain damage after oxygen shortage. Myers $(4,5)$ induced brain injury in neonatal monkeys. The animals were anesthetized or heavily sedated, and after asphyxia resuscitation was performed on a neonatal intensive care unit. The majority of monkeys, sustaining episodes of asphyxia severe enough to lead to widespread cerebral damage, also had injury to the myocardium, which resulted in death from cardiogenic shock within the first day or two after the insult (5). Levine circumvented that problem in adult rats by combining unilateral carotid artery ligation with hypoxic exposure, thereby increasing the susceptibility for oxygen shortage in the ischemic cerebral hemisphere (6). In fetal lambs it seemed more difficult to obtain an adequate survival rate concomitant with an acceptable degree of histologic damage (7). The narrow threshold between a degree of intrauterine asphyxia associated with no sequelae, an insult causing persistent cerebral impairment, and an insult resulting in intrauterine demise was confirmed. Recently, the Levine model was modified for fetal sheep. Ligation of the vertebral-carotid anastomosis and inflation of occluder cuffs around both carotid arteries for 30 minutes resulted in ischemic encephalopathy (8).

However, although most setups described above led to reproducible and quantifiable brain damage, experimental cerebral ischemia is entirely different from the primarily hypoxic mechanism encountered in clinical practice. Therefore the pathophysiological condition of acute fetal asphyxia was mimicked in the present study by reducing maternal placental perfusion. The objective of the study was to induce severe asphyxia and evaluate its effect on (I) the fetal cardiovascular system and cerebral blood flow (CBF), (II) systemic and brain metabolic parameters (levels of CSF lactate, CSF hypoxanthine, and CSF xanthine), the latter two are considered substrates in the formation of oxygen derived free radicals, involved in the induction of post-asphyxial tissue damage (9), (III) histology of the brain after 3 days survival.

\section{Material and methods}

\section{Surgery}

Surgery was performed in 7 pregnant Dutch Texel sheep of known mating dates between 118 and 124 days' gestation (mean $\pm \mathrm{SD}=120.9 \pm 2.0$ days, term= 147 days). General anesthesia was induced with intravenous pentobarbital and maintained with $1 \%$ halothane in a $2: 1$ mixture of nitrous oxide and oxygen. Before surgery, the ewes received $1 \mathrm{~g}$ of intravenous ampicillin. Under sterile 
conditions, a paramedian abdominal incision was made and an inflatable balloon occluder was placed around the maternal common internal iliac artery. Fetal instrumentation involved insertion of polyvinyl catheters in the axillary and femoral artery, the tips advanced to the level of the brachiocephalic trunk and descending aorta, respectively. In addition, catheters were placed in the femoral vein, the tip advanced into the inferior vena cava, and in the amniotic cavity. A polyvinyl catheter was placed in the spinal cisterne to obtain CSF. Catheters were exteriorized to the ewe's flank.

Ewes were housed in individual cages with free access to food and water and were allowed to recuver from surgery for at least 3 days before the experiments were started. A continuous slow infusion ( $1 \mathrm{~mL} /$ hour) of heparin in saline $(10 \mathrm{U} / \mathrm{mL})$ was used to maintain patency of fetal arterial and venous catheters. Guidelines for care and use of animals, as approved by the local Animal Medical Ethics Committee, were followed.

\section{Measurements}

Fetal $\mathrm{Pa}, \mathrm{Pv}$, and amniotic pressure were determined with the zero point at the level of the ewe's spine. These signals, together with the FHR derived from the pulsatile signal of the femoral artery were led to a bioelectric amplifier (Hewlett Packard 8800 series, Andover, Mass., USA), displayed on a monitor, recorded on eight-channel strip chart recorder, stored on magnetic tape, and digitized and analyzed with a computer.

Regional CBF was measured with radioactive microspheres with a diameter of $15 \mu \mathrm{m}$. At random one out of four available microspheres $\left({ }^{95} \mathrm{Nb}\right.$, ${ }^{103} \mathrm{Ru},{ }^{113} \mathrm{Sn}$, and ${ }^{141} \mathrm{Ce}$ ) was injected. Aggregation of microspheres was prevented by adding Tween 80 to the injection medium. After homogenization in an ultrasonic waterbath at $39^{\circ} \mathrm{C}$ (Bransonic 5200 , Soest, the Netherlands) for 20 minutes, approximately $0.5 \times 10^{6}$ microspheres were stirred on a vortex agitator, and infused into the inferior vena cava over a period of 1 minute. Reference sampling ( $1.80 \mathrm{~mL} / \mathrm{min}$ ) (Harvard Apparatus Ltd., Kent, England) was started from the brachiocephalic arch 30 seconds before infusion, continued during, and stopped 1 minute after infusion.

Blood gas values and $\mathrm{pH}$ from the fetal aortic arch were measured with an automated analyzer (AVL, Radiometer, Copenhagen, Denmark) and corrected for $39^{\circ} \mathrm{C}$. Hb saturation was measured with an hemoximeter (OSM2 Hemoximeter, Radiometer). The $\left[\mathrm{O}_{2}\right]$ a was calculated as follows: $\left[\mathrm{O}_{2}\right]$ a (in $\mathrm{mM}$ ) $=\mathrm{Hb}$ concentration $(\mathrm{mM}) \times \mathrm{Hb}$ oxygen saturation $(\% / 100)$. Immediately after a microsphere injection $2 \mathrm{~mL}$ of blood was withdrawn from the axillary artery and centrifuged ( 3 minutes at 13,000 revolutions/min). Serum was frozen in liquid nitrogen and stored at $-73^{\circ} \mathrm{C}$.

Samples of CSF were withdrawn with a $1 \mathrm{~mL}$ syringe from the catheter in the spinal cisterne, centrifuged ( 3 minutes at 13,000 revolutions/min) and frozen in 
liquid nitrogen. The catheter deadspace was shortened to approximately $0.2 \mathrm{~mL}$, the volume of CSF obtained per sample was at least $0.6 \mathrm{~mL}$. After storage at $-73^{\circ} \mathrm{C}$, serum and C.SF samples from all animals were analyzed together. Concentrations of lactate were measured, whereas levels of hypoxanthine and xanthine were determined by high performance liquid chromatography (10).

\section{Experiments}

Mean gestational age $( \pm$ SD) during experiments was $124.3( \pm 2.6)$ days. FHR, $\mathrm{Pa}$, and $\mathrm{Pv}$, were monitored continuously. Fetal acid-base balance was analyzed every 15 minutes. To improve myocardial performance after asphyxia (11), the fetal lambs received an intravenous bolus of the adenosine transport inhibiting drug R-75231 (2-(aminocarbonyl)-N-(4-amino-2,6-dichlorophenyl)-4[5,5-bis(4-fluorophenyl)-pentyl]-1-piperazineacetamine, Janssen Pharmaceutica, Beerse, Belgium) in a dose of $0.1 \mathrm{mg} / \mathrm{kg}$ estimated fetal weight in the inferior vena cava before the onset of occlusion. Estimation of fetal weight was performed during instrumentation.

After microsphere injection in the baseline period, fetal asphyxia was induced. To maintain the fetus in a stable hemodynamic condition, uterine blood flow was gradually reduced by stepwise inflation of the balloon occluder around the common internal iliac artery, over a period of approximately 120 minutes, until fetal $\left[\mathrm{O}_{2}\right]$ a reached a value of $40 \%$ of baseline, in combination with an aortal $\mathrm{pH}$ $<7.15$. This moment was considered time $=0 \mathrm{~min}$ and occlusion was kept at the same level for 1 hour. At time $=60 \mathrm{~min}$, the peak of asphyxia, microspheres were injected to calculate CBF. Thereafter the uterine blood flow obstruction was discontinued by emptying the balloon occluder. The third and fourth dosage of microspheres were administered in the recovery phase, at time $=90 \mathrm{~min}$ and at time $=180 \mathrm{~min}$, corresponding with 0.5 and 2 hours after release of the occluder, respectively.

\section{Fixation procedure and histologic evaluation}

Three days after the period of asphyxia a relaparotomy was performed under general anesthesia. The fetus was completely heparinized by $15,000 \mathrm{U}$ intravenous heparin. The fetal heart was approached by median thoracotomy. A blunt steel catheter was inserted in the left ventricle. The right atrium was opened, and $500 \mathrm{~mL}$ of isotonic and buffered isocolloidal fluid $\left(39^{\circ} \mathrm{C}\right)$ was infused. The descending aorta was clamped. The fetal brain was preserved by intracardial perfusion with Karnovsky's fixative (2\% formaldehyde and $2.5 \%$ glutaraldehyde in phosphate buffer $0.1 \mathrm{M}, \mathrm{pH} 7.40$ ), approximately $1 \mathrm{~L}$ at room temperature. The fetus was weighed and correct catheter placement was confirmed. After one day immersion fixation in Karnovsky's fixative, the fetal brain was removed from the skull, and was sampled for CBF determination and histologic analysis. according to a stereotaxic atlas of the ovine fetal brain (12). After scintillation counting, 
vibratome sections $(200 \mu \mathrm{m})$ were cut from eight cerebral areas (frontal cortex, parietal cortex, temporal cortex, striatum, hippocampus, cerebellum, thalamus and medulla oblongata). Sections were postfixed in $2 \%$ osmium tetroxide, buffered with veronal acetate $(0.05 \mathrm{M}, \mathrm{pH} 7.40)$, dehydrated in graded series of ethanol and routinely embedded in Epon. Light microscopic evaluation was performed on 2 $\mu \mathrm{m}$ sections stained with toluidine blue. Fixation quality was scored on a 10-point scale (13) whereby 10 corresponds with preservation in which no residual erythrocytes are detected, with open microvessels and without disseminated cell swelling. A zero corresponded with a morphologic picture, dominated by collapsed microvessels filled with residual erythrocytes and surrounded by spongy brain parenchyma. Two characteristic types of hypoxic cell changes were evaluated: edematous cell changes, mainly involving the glial compartment, and coagulative neuronal cell changes. Cell changes were also scored on a 10-point scale, whereby 0 is absence of coagulative changes and 10 is $100 \%$ of the tissue damaged (13).

\section{Calculations and data analysis}

The $\mathrm{Pa}$, corrected for amniotic pressure, was averaged over 10 seconds periods, using a computer program. Five of these epochs were averaged to calculate mean $\mathrm{Pa}$.

Samples from the eight cerebral areas were weighed $( \pm 1 \mathrm{~g})$, put into test tubes and preserved in $3 \%$ glutaraldehyde solution. Radioactivity in all samples was determined before histologic evaluation. All four isotopes were counted simultaneously. Radioactivity in tissue and in reference samples was measured with an automatic gamma scintillation counter and sample changer system (analyzer model 45, Molsgaard Medical, Horsholm, Denmark), connected to a ND680 programmable analyzer/computer system (Nuclear Data GmbH, Frankfurt, Germany).

Parameters during asphyxia and in the recovery period were compared with bascline values, by means of a Friedman analysis of variance, with time as the repeated measure. A $p<0.05$ was taken to represent statistical significance.

\section{Results}

The time course of mean $\left[\mathrm{O}_{2}\right] \mathrm{a}, \mathrm{pH}$, and $\mathrm{Pa}$ is depicted in Figure 6.1. The $\left[\mathrm{O}_{2}\right]$ a decreased gradually, and was approximately $40 \%$ of baseline level during the period of asphyxia. During the occlusion period the mean $\mathrm{pH}$ decreased from 7.36 to 6.99 . Release of the occluder resulted in recovery, with a mean $\mathrm{pH}$ of 7.22 at $180 \mathrm{~min}$. Pa remained unaltered during the entire experiment.

Table 6.1 summarizes the fetal $\left[\mathrm{O}_{2}\right] \mathrm{a}, \mathrm{pH}, \mathrm{pCO}_{2}, \mathrm{BE}$, serum glucose levels and serum lactate concentrations. Glucose levels remained unaltered during the experiment, but serum lactate levels rose during asphyxia more than eightfold compared with bascline levels (Friedman two way analysis of variance, $\mathrm{p}<0.05$ ), and remained elevated during the hours monitored in the recovery phase. 


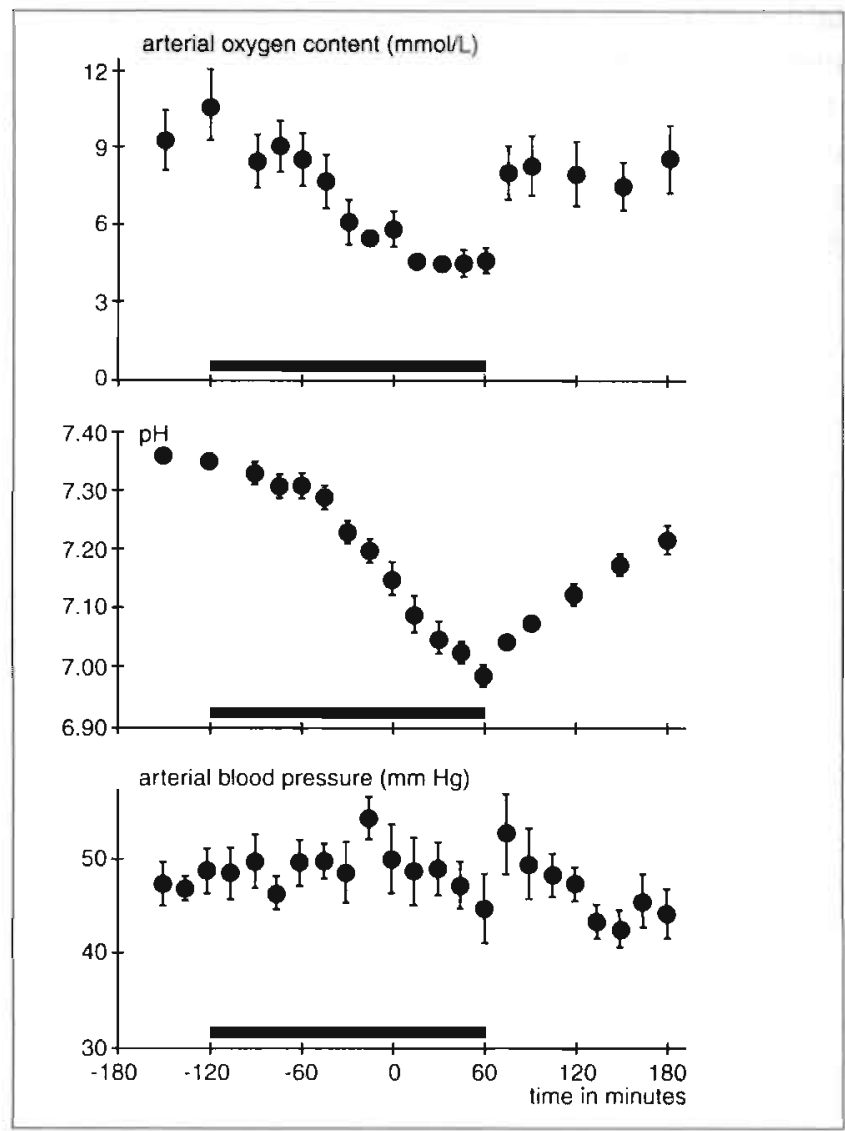

Figure 6.1. Time course of $\left[\mathrm{O}_{2}\right] \mathrm{a}(\mathrm{mM}), \mathrm{pH}$ and $\mathrm{Pa}(\mathrm{mm} \mathrm{Hg}), \mathrm{n}=7$, expressed as mean \pm SEM. Time -180 to $-120 \mathrm{~min}=$ baseline period; time -120 to $0 \mathrm{~min}=$ progressive reduction of uterine blood flow; time 0 to $60 \mathrm{~min}=1$ hour period of asphyxia; time 60 to $180 \mathrm{~min}=$ recovery period. Bar, period of occlusion.

Table 6.1. Fetal acid-base balance and serum glucose and lactare levels

\begin{tabular}{|ll|c|c|c|c|}
\hline & & Baseline & Asphyxia & time $=90$ & time $=180$ \\
\hline$\left[\mathrm{O}_{2}\right] \mathrm{a}$ & $(\mathrm{mM})$ & $3.31 \pm 0.42$ & $1.56 \pm 0.16^{*}$ & $2.80 \pm 0.41$ & $2.91 \pm 0.45$ \\
$\mathrm{pH}$ & & $7.36 \pm 0.01$ & $6.99 \pm 0.02^{*}$ & $7.08 \pm 0.01^{*}$ & $7.22 \pm 0.03^{*}$ \\
$\mathrm{PCO}_{2}$ & $(\mathrm{kPa})$ & $5.15 \pm 0.20$ & $7.37 \pm 0.33^{*}$ & $6.14 \pm 0.19^{*}$ & $5.57 \pm 0.19$ \\
$\mathrm{BE}$ & $(\mathrm{mM})$ & $-4.1 \pm 0.8$ & $-17.6 \pm 0.9^{*}$ & $-15.6 \pm 0.3^{*}$ & $-9.4 \pm 1.7^{*}$ \\
$\begin{array}{l}\text { serum } \\
\text { glucose }\end{array}$ & $(\mathrm{mM})$ & $1.05 \pm 0.14$ & $0.96 \pm 0.18$ & $0.96 \pm 0.09$ & $1.02 \pm 0.10$ \\
$\begin{array}{l}\text { serum } \\
\text { lactate }\end{array}$ & $(\mathrm{mM})$ & $1.8 \pm 0.5$ & $14.7 \pm 0.6^{*}$ & $14.4 \pm 0.6^{*}$ & $11.5 \pm 0.7^{*}$ \\
\hline
\end{tabular}

Values are expressed as mean \pm SEM, $n=7$. Asphyxia is at time $=60 \mathrm{~min}$, at the peak of asphyxia. Time $=90 \mathrm{~min}$ and time $=180 \mathrm{~min}$ corresponds with 0.5 and 2 hours after release of the occluder, respectively.

*: $\mathrm{p}<0.05$ (asphyxia, time $=90 \mathrm{~min}$ or time $=180 \mathrm{~min}$ versus baseline, Friedman two way ANOVA 
All fetal lambs in this study were succesfully instrumented with a catheter in the spinal cisterne. It was not always possible to maintain patency of these catheters, and therefore CSF could be collected in five preparations only. Because of sampling problems, CSF could not be obtained on standardized moments. The results of CSF analysis are depicted in Figure 6.2. During the hour of severe asphyxia concentrations of lactate, hypoxanthine, and xanthine, started to rise, which continued during the first hours of recovery. Maximum values of hypoxanthine and xanthine in CSF were found approximately at 180 minutes. Thereafter the concentrations returned to normal. CSF lactate levels however, remained almost unchanged during the 3 hours after asphyxia, at a level of approximately $9 \mathrm{mM}$.

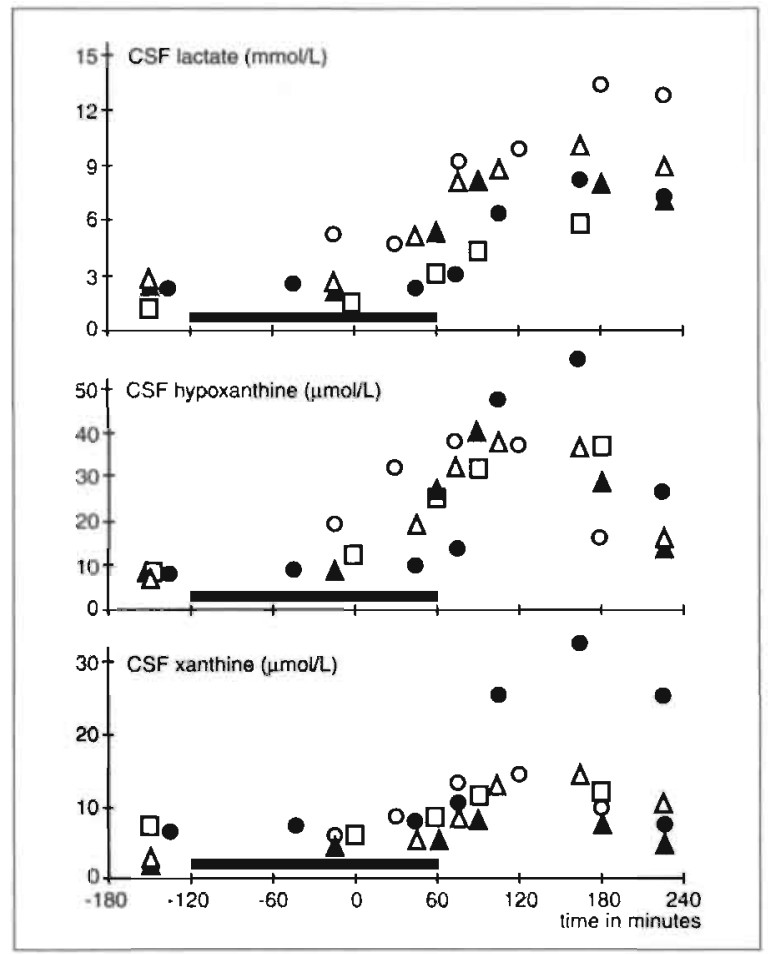

Figure 6.2. CSF levels ( $\mathrm{n}=5$ ) of lactate in $\mathrm{mM}$ (upper panel), hypoxanthine in $\mu \mathrm{M}$ (middle panel). and xanthine in $\mu \mathrm{M}$ (lower panel) during the experiment. All five individual animals are represented hy a specific symbol. Time -180 to $-120 \mathrm{~min}=$ baseline period; time -12 ) to $0 \mathrm{~min}=$ progressive reduction of uterine blood flow; time 0 to $60 \mathrm{~min}=1$ hour period of asphyxia; time 60 to $240 \mathrm{~min}=$ recovery period. Bar, period of ncclusion. 
The weight specific regional CBF (in $\mathrm{mL} / \mathrm{min} \times 100 \mathrm{~g}$ ) is shown in Table 6.2. During asphyxia CBF in all anatomical areas increased, whereas normalization occurred in the recovery period.

Table 6.2. Regional cerebral blood flow

\begin{tabular}{|l|c|c|c|c|}
\hline & Baseline & Asphyxia & time $=90$ & time $=180$ \\
\hline Frontal cortex & $135 \pm 20$ & $278 \pm 55^{*}$ & $143 \pm 26$ & $154 \pm 34$ \\
Parietal cortex & $129 \pm 22$ & $288 \pm 59^{*}$ & $134 \pm 22$ & $157 \pm 42$ \\
Temporal cortex & $133 \pm 30$ & $295 \pm 57^{*}$ & $122 \pm 23$ & $141 \pm 36$ \\
Striatum & $156 \pm 23$ & $362 \pm 57^{*}$ & $156 \pm 28$ & $202 \pm 45$ \\
& & & & \\
Hippocampus & $151 \pm 27$ & $372 \pm 79^{*}$ & $154 \pm 34$ & $173 \pm 57$ \\
Thalamus & $234 \pm 52$ & $546 \pm 80^{*}$ & $239 \pm 50$ & $291 \pm 85$ \\
Cerebellum & $208 \pm 34$ & $476 \pm 63^{*}$ & $252 \pm 36$ & $281 \pm 63$ \\
Medulla oblongata & $292 \pm 69$ & $776 \pm 18^{*}$ & $326 \pm 70$ & $357 \pm 94$ \\
\hline
\end{tabular}

Values are expressed in $\mathrm{mL} / \mathrm{min} \times 100 \mathrm{~g}$, and as mean $\pm \mathrm{SEM}, \mathrm{n}=7$. Asphyxia is at time $=$ $60 \mathrm{~min}$, at the peak of asphyxia. Time $=90 \mathrm{~min}$, and time $=180 \mathrm{~min}$ corresponds with 0.5 and 2 hours after release of the occluder, respectively.

*: $p<0.05$ (asphyxia versus baseline, Friedman two way analysis of variance)

All seven fetuses recovered and were in a good metabolic condition the day after asphyxia. One ewe developed contractions and the fetus died during labor. The period between intra-uterine fetal death and birth resulted in a poor quality of fixation, which made reliable histologic evaluation impossible (Table 6.3; lamb no. 5). Another fetal lamb bled to death because of a catheter accident. The brain of this animal was immersion fixed; it showed typical morphologic signs of inadequate fixation (e.g., a high amount of residual erythrocytes, extreme swelling of the perivascular and perineuronal glial compartment, densification of neuronal cell bodies and granular appearance of nuclear chromatin (Table 6.3; lamb no. 4)). It was impossible to differentiate these changes from subtle experimental hypoxic damage. Five fetuses survived for 72 hours after asphyxia. This 3 -day period was chosen to allow delayed neuronal cell death to become histologically manifest $(14,15)$. The metabolic condition of these five animals during the whole experiment did not differ from that of the two animals lost for perfusion fixation because of labor and hemorrhage. The brains of the five fetuses were adequately perfused (Figure 6.3; Table 6.3). Structural abnormalities in the brains of these survivors were scarce. No changes were present that could be attributed to microsphere embolism. A variable degree of edema was found in white and gray matter. Coagulative neuronal cell changes, characteristic for irreversible cell death $(13,15)$ were only occasionally detected in four animals (Table 6.3). These changes were most obvious in the Purkinje cells of the cerebellum (Figure 6.4). 
Table 6.3. Degree of fixation and histologic evaluation

\begin{tabular}{|c|c|c|c|c|c|c|c|c|c|c|c|c|c|c|}
\hline \multirow{2}{*}{$\begin{array}{c}\operatorname{lamb} \\
\text { no. }\end{array}$} & \multirow{2}{*}{$\begin{array}{l}\text { Survival } \\
\text { (hours) }\end{array}$} & \multirow{2}{*}{$\begin{array}{c}\text { degree } \\
\text { of } \\
\text { fixation }\end{array}$} & \multicolumn{6}{|c|}{ edematous cell changes } & \multicolumn{6}{|c|}{ coagulative cell changes } \\
\hline & & & sit & $\operatorname{ctx}$ & thl & hip & cer & med & str & $\mathrm{ctx}$ & [h] & hip & cer & med \\
\hline 1 & 72 & 6.0 & 4 & 6 & 6 & 2 & 4 & 1 & 0 & 0 & 0 & 0 & 0 & 0 \\
\hline 2 & 72 & 5.3 & 3 & 2 & 1 & 4 & 4 & 0 & 0 & 3 & 1 & 0 & 4 & 0 \\
\hline 3 & 72 & 7.7 & 1 & 1 & 0 & 1 & 0 & 0 & 0 & 0 & 0 & 0 & 2 & 0 \\
\hline 4 & 24 & 0.2 & 4 & 4 & 4 & 6 & 6 & 4 & $?$ & $?$ & 0 & 0 & 4 & 1 \\
\hline 5 & 22 & $n p$ & $n p$ & pח & $n p$ & $n p$ & $n p$ & np & $n p$ & $n p$ & $n p$ & $n p$ & np & np \\
\hline 6 & 72 & 9.0 & 1 & 1 & 0 & $\mathrm{np}$ & 0 & 0 & 0 & 0 & 0 & $n p$ & I & 0 \\
\hline 7 & 72 & 7.6 & 0 & 1 & 0 & 0 & 0 & $n p$ & 0 & 0 & 0 & 0 & 0 & $\mathrm{np}$ \\
\hline
\end{tabular}

Histological cell changes were scored in eight cerebral entities: $s t r$, siriatum: $t h$, thalamus: hip, hippocampus; $c e r$, cerebellum; med, medulla oblongata; whereas $c t x$ summarizes the results of evaluation of the frontal, parietal and temporal cortex. $\mathrm{np}=$ not performed. Details for the scoring of the degree of fixation and histologic brain damage $(13,15)$ are provided in the text.

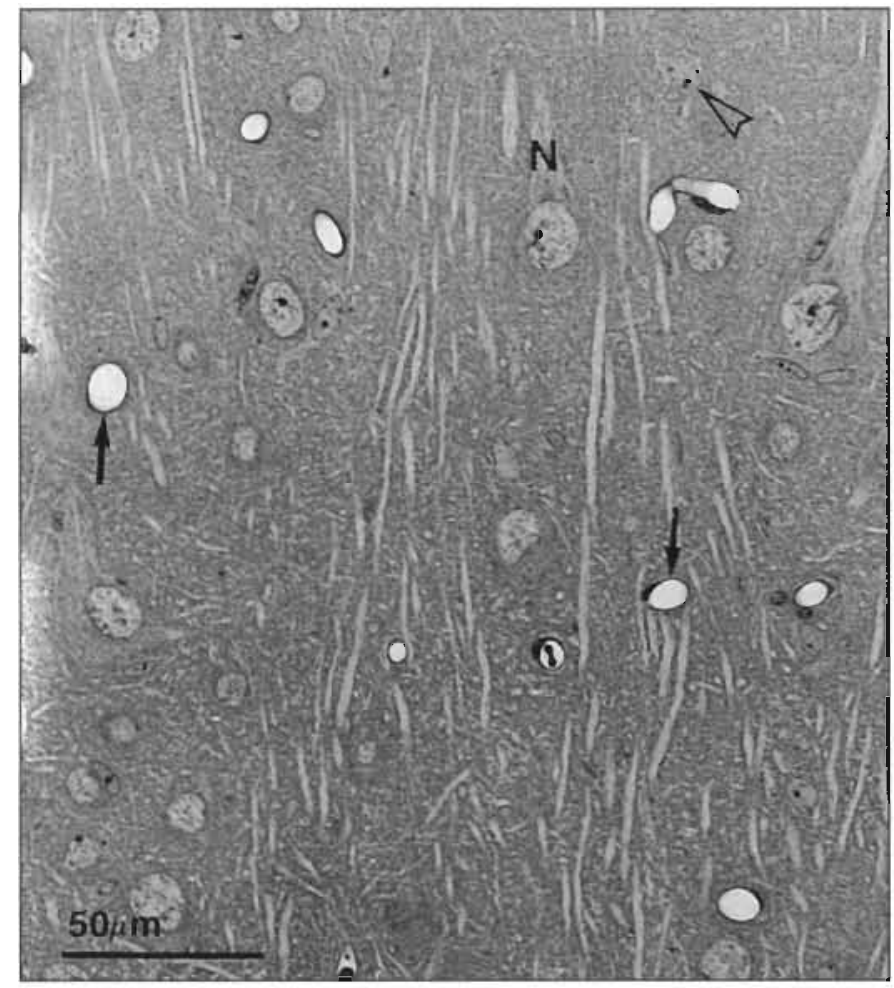

Figure 6.3. Section of adequately fixed fetal cortex 72 hours after a period of severe asphyxia. Microvessels appear nicely expanded (arrows) and are surrounded by a compact neuropil. Neurons ( $N$ ) and glial cells (arrowhead) are well preserved as can be derived from the absence of any coagulative or edematous cell changes ( $2 \mu \mathrm{m}$; toluidine blue). 


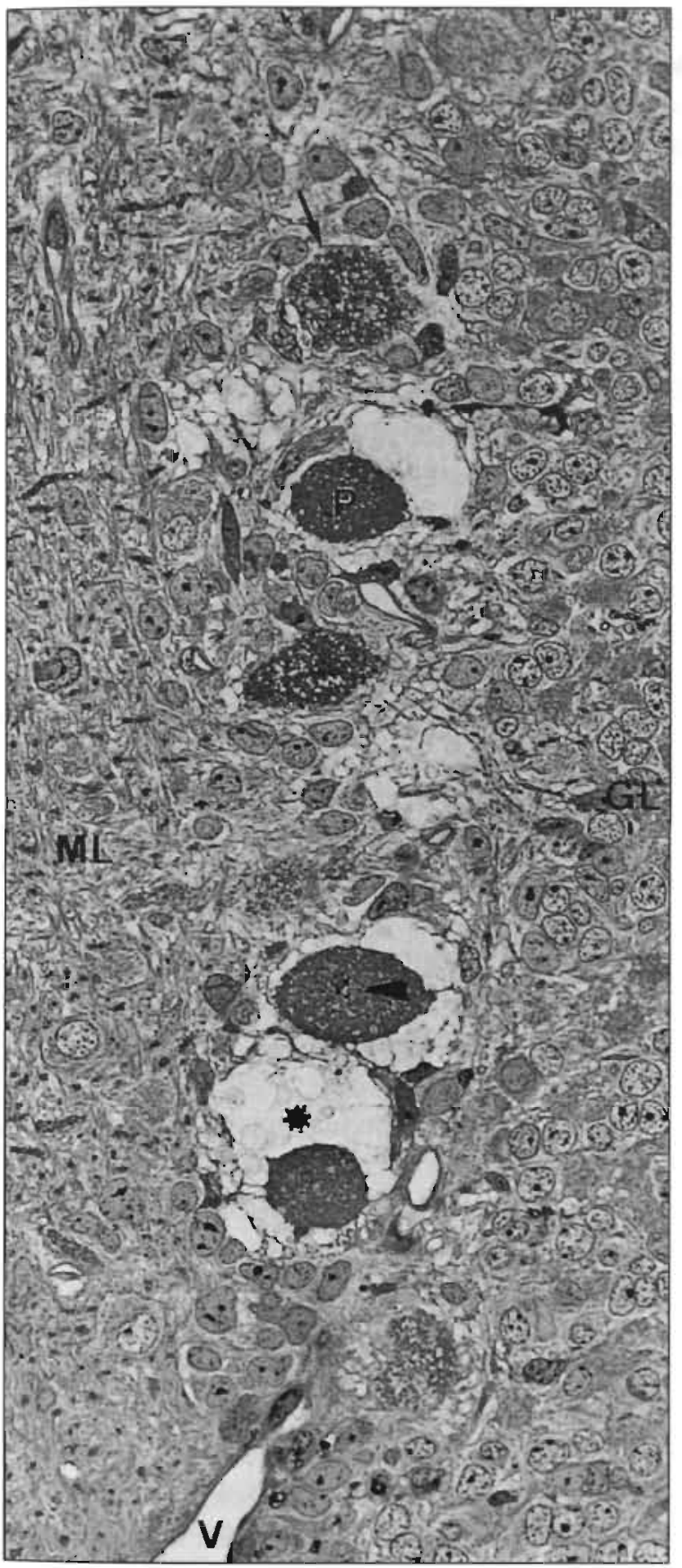

Figure 6.4. Detail of fetal cerebellum 72 hours after a period of severe asphyxia. Purkinje cells $(P)$ show characteristic coagulative cell change with cytoplasmic microvacuolation (arrow) and nuclear pyknosis (arrowhead). Surrounding glial cells are extremely dilated (asterisk). Granular cell layer (GL) and molecular cell layer $(M L)$ appear unaltered ( $2 \mu \mathrm{m}$; toluidine blue). 


\section{Discussion}

Reduction of uterine perfusion with an inflatable balloon occluder resulted in the fetus in a decreased $\left[\mathrm{O}_{2}\right] \mathrm{a}$, the onset of anaerobic metabolism, the production of lactate, and a decrease in $\mathrm{pH}$. Mean $\mathrm{Pa}$ was $48.0 \pm 0.6 \mathrm{~mm} \mathrm{Hg}$ and remained at the same level during and after asphyxia (Figure 6.1). This is in agreement with previous data $(16,17)$. The $\mathrm{Pa}$ gathers importance since intermittent increases of cerebral intravascular pressure during asphyxia caused hemorrhages in the germinal layer of fetal sheep brain (18). On the other hand, also hypotension has been shown to be associated with neuronal damage $(7,19)$.

During asphyxia adenosine is primarily released in the myocardium. Adenosine is considered as a natural cardioprotector because of its coronary vasodilative and antiadrenergic effects, and its inhibition of the activation of platelets and leukocytes (10). Pretreatment with the adenosine transport inhibiting drug R-75231 therefore preserves the function of the myocardium when the heart has been compromized by severe asphyxia (11), and was shown to improve myocardial functioning after heart transplantations in dogs (20). Therefore, we hypothesized that after pretreatment with R-75231 the degree of asphyxia might be severe enough to cause cerebral damage without the concomitant fetal death from cardiogenic injury.

Baseline values of CBF were in agreement with previous results (16) and literature (21). CBF increased in the period of asphyxia. During asphyxia the increase in CBF was greater in phylogenetic older structures, such as medulla oblongata and cerebellum, than in the cortex.

In the current study fetuses remained normoglycemic (Table 6.1) when compared with literature data on glucose levels $(7,22,23)$. Apparently the fetuses were able to maintain normal glucose concentrations in spite of severe asphyxia. Hyperglycemia, shown to reduce the tolerance of the brain toward asphyxia (22), was not detected in any fetal lamb. The potentially negative impact on the brain of (experimentally induced) high levels of glucose during oxygen lack was ascribed to the concomitant tissue acidosis (24). Therefore, in the current study, brain damage is not explained by an additional hyperglycemia.

After release of the occluder the $\left[\mathrm{O}_{2}\right]$ a returned to normal, leading to recovery of the fetal acid-base balance. The time course of recovery after this degree of asphyxia is in agreement with data from other investigators (19). CSF lactate levels still increased during this recovery phase (Figure 6.2). Maximum concentrations were reached approximately 2 hours after the end of uterine blood flow obstruction. After this moment there appeared to be a trend toward normalization. CSF concentrations of hypoxanthine and xanthine (Figure 6.2), both catabolites of adenosine 5 '-triphosphate, started to increase during the hour of severe asphyxia. At time $=60 \mathrm{~min}$, the start of the recovery period, levels of CSF lactate, CSF hypoxanthine and CSF xanthine were only slightly elevated. However, during the recovery period the concentration of these catabolites 
continued to rise. Maximum concentrations (fivefold, fivefold, and fourfold the baseline levels of CSF lactate, CSF hypoxanthine, and CSF xanthine, respectively) were reached at approximately time $=180 \mathrm{~min}$. Next to damage to the blood-brainCSF compartment barrier, delayed neuronal damage may also partiy explain the increase of hypoxanthine and xanthine in the recovery period (14). During this phase the $\left[\mathrm{O}_{2}\right]$ a returned to baseline levels. The enzyme xanthine-oxidase is released under hypoxic conditions from the liver into the circulation (9), and is present in the brain (25). This enzyme metabolizes hypoxanthine and xanthine to excretable uric acid, during which process oxygen derived free radicals are formed $(26,27)$. High levels of hypoxanthine and xanthine in the brain, in combination with normal levels of oxygen in the recovery phase, may facilitate oxygen derived free radical formation and aggravate post-asphyxial brain damage (9). This could explain the beneficial effect of oxygen free radical scavengers in various experiments with asphyxiated animals $(28,29)$.

Although in the present study the degree of asphyxia was severe, as indicated by a mean $\mathrm{pH}<7.00$, serum lactate levels $>14 \mathrm{mM}$, and a $\mathrm{BE}>-17$ $\mathrm{mmol} / \mathrm{L}$ (Table 6.1; Figure 6.1), extensive histological brain damage was not observed. Cerebral edema was present in the majority of fetuses. From Table 6.3 it can be derived that the degree of fixation was inversely correlated with edematous cell changes. However, the question remains if this edema is a post-mortem effect after incomplete fixation or if the incomplete fixation is a result of edema induced by the asphyxial insult. The latter is supported by combining the CSF hypoxanthine and CSF xanthine data with the results of histologic studies. Animal no. I (Table 6.3) is depicted in Figure 6.2 with open circles; edematous cell changes at histologic evaluation corresponded with the highest level of CSF lactate and a long period of elevated levels of CSF hypoxanthine. Animal number 2 is depicted with filled circles in Figure 6.2. Edematous cell changes are present throughout the whole cerebrum in the fetus that had the highest amount of CSF hypoxanthine and CSF xanthine (Figure 6.2). Cerebellar Purkinje cells were shown to be most sensitive to oxygen deprivation (Figure 6.4). These cells have highly branched dendritic trees, receiving a huge amount of synaptic input from axon terminals. During asphyxia these large cells may encounter a nutrient supply smaller than their minimum needs, resulting in irreversible cell death. The sensitivity of Purkinje cells for oxygen shortage was confirmed in experiments in other species. In adult cat brain chronic hypoxia mostly affected the Purkinje cells located in the deeper portions of cerebellar folia (30). After severe asphyxia and resuscitation most newborn pigs showed some anoxic cerebellar damage with scattered necrotic Purkinje cells (31). In the latter two experiments and in the current study the insult was primarily hypoxic, and damage was predominantly located in the cerebellum. This is in contrast to brain ischemic experiments, which primarily result in damage of the parasagittal cortex (8). This cortical area is considered to be a watershed area: an arterial end field in the border zone between 
the territories of major cerebral arteries. During ischemia the relative sparing of midbrain and hindbrain structures such as the cerebellum, when compared with the cortex, may reflect preferential perfusion of the residual normoxemic blood flow to these structures (32).

In sheep various methods were used to reduce fetal oxygen delivery to induce brain damage; umbilical cord occlusion led to hippocampal brain damage (33) and common internal iliac artery occlusion led to parasagittal cortex and striatum damage (19). In the latter study, damage was not extensive: only three of the 14 surviving fetuses demonstrated $>10 \%$ damage, and six of the 14 animals showed no damage at all. The authors presumed that differences in cerebral lactate concentration could be an explanation of the regional differences in neuronal loss between the two studies, but neither neuronal nor CSF lactate levels were measured.

The lack of extensive brain damage reported after various types of cerebral hypoxia confirms the statement about the existence of a narrow margin between lethality after asphyxia on the one hand, and survival without signs of histologic damage on the other hand (34). Finally, adequate perfusion fixation is an absolute necessity, especially because the brain is extremely sensitive to postmortem changes and since these changes closely resemble lesions induced by mild hypoxia (35).

In summary, restriction of maternal uterine blood flow resulted in increased fetal serum lactate concentrations and severe asphyxia. During asphyxia animals increased their CBF, remained normotensive and normoglycemic. CSF concentrations of lactate, hypoxanthine, and xanthine, increased fivefold, fivefold, and fourfold, respectively. Maximum concentrations of CSF hypoxanthine and CSF xanthine were reached in the recovery period following asphyxia, and were associated with edematous cell changes. In the recovery period the $\left[\mathrm{O}_{2}\right]$ a returned to baseline values. This reoxygenation may facilitate oxygen derived free radical formation, and may thus aggravate postasphyxial brain damage. In distinguishing between histologic damage as a result of asphyxia or as a postmortem artifact, perfusion fixation appeared to be important. The absence of extensive histologic brain damage indicates that, under normotensive and normoglycemic conditions, the fetal brain can tolerate severe usphyxia. Cerebellar Purkinje cells tended to be most sensitive to asphyxia.

\section{Acknowledgments}

We thank May Bost, Joyce Suyk, Jan Geilen, and Marc Haseldonckx for skillful technical assistance, Anke IJzermans for assistance in performing the experiments, Frans Slangen and Peter Franssen for animal care, and Guy Jacobs for preparation of the photographs. 


\section{References}

1. Parer JT, Livingston EG 1990 What is fetal distress? Am J Obstet Gynecol 162:14211427

2. Low JA, Galbraith RS, Muir DW, Killen HL, Pater EA, Karchmar EJ 1988 Motor and cognitive deficits after intrapartum asphyxia in the mature fetus. Am J Obstet Gynecol $1.58: 356-361$

3. Goodwin TM, Belai I, Hernandez P, Durand M, Paul RH 1992 Asphyxial complications in the term newborn with severe umbilical acidemia. Am J Obstet Gynecol 167:1506-1512

4. Myers RE 1972 Two patterns of perinatal brain damage and their conditions of occurrence. Am J Obstet Gynecol 1 12:246-276

5. Myers RE 1975 Four patterns of perinatal brain damage and their conditions of occurrence in primates. Adv Neurol 10:223-234

6. Levine $S 1960$ Anoxic-ischemic encephalopathy in rats. Am J Pathol 36:1-17

7. Ting P, Yamaguchi S, Bacher JD, Killens RH, Myers RE 1983 Hypoxic-ischemic cerebral necrosis in midgestational sheep tetuses: physiopathologic correlations. Exp Neurol 80:227-245

8. Williams CE, Gunn AJ. Synek B. Gluckman PD 1990 Delayed seizures occurring with hypoxic-ischemic encephalopathy in the fetal sheep. Pediatr Res 27:561-565

9. Saugstad OD 1988 Hypoxanthine as an indicator of hypoxia: its role in health and disease through free radical production. Pediatr Res 23:143-150

10. Van Belle H, Goossens F, Wynants J 1987 Formation and release of purine catabolites during hypoperfusion, anoxia, and ischemia. Am J Physiol 252:H886-H893

11. de Haan HH, de Haan J, Van Reempts JLH, Van Belle H, Hasaart THM 1993 The effect of adenosine transport inhibition on cardiovascular function and survival after severe asphyxia in fetal lambs. Pediatr Res 33:185-189

12. Gluckman PD, Parsons Y 1984 Stereotaxic neurosurgery on the ovine fetus. In: Nathanielsz. PW (ed) Animal models in fetal medicine (III). Perinatology Press, New York, pp 69-107

13. Van Reempts JLH 1984 The hypoxic brain: histological and ultrastructural aspects. Behav Brain Res 14:99- 108

14. Pulsinelli WA, Brierley JB, Plum JB 1982 Temporal profile of neuronal damage in a model of transient forebrain ischemia. Ann Neurol 1 1:491-498

15. Van Reempts JLH. Borgers M 1990 Structural damage in experimental cerebral ischemia. In: Schurr A, Rigor BM (eds) Cerebral ischemia and resuscitation. CRC Press. Boca Raton, pp 235-257

16. de Haan HH, Van Reempts JLH. Borgers M. de Haan J. Vles JSH, Hasaart THM 1993 Possible neuroprotective properties of flumarizine infused after severe asphyxia in fetal lambs are not explained by elfects on cerebral blood flow or systemic blood pressure. Pediatr Res 34:379-384

17. Field DR, Parer JT, Auslender RA, Cheek DB, Baker W, Johnson J 1990 Cerebral oxygen consumption during asphyxia in fetal sheep. J Dev Physiol 14:131-137

18. Reynolds ML, Evans CAN, Reynolds EOR, Saunders NR, Durbin GM, Wigglesworth JS 1979 Intracranial haemorrhage in the preterm sheep fetus. Early Human Dev 3:163-186 
19. Gunn AJ, Parer JT, Mallard EC. Williams CE, Gluckman PD 1992 Cerebral histologic and electrocorticographic changes after asphyxia in fetal sheep. Pediatr Res 31:486491

20. Flameng W, Sukehiro S, Möllhoff T, Van Belle H, Janssen PAJ 1992 A new concept of long-term donor heart preservation: nucleoside transport inhibition. J Heart and Lung Transplant 10:990-998

21. Peeters LLH, Sheldion RE, Jones MD, Makowski EL, Meschia G 1979 Blood flow to fetal organs as a function of arterial oxygen content. Am J Obstet Gynecol 135:637646

22. Blomstrand S, Hrbek A, Karlsson K, Kjellmer I, Lindecrantz K, Olsson T 1984 Does glucose administration affect the cerebral response to fetal asphyxia? Acta Obstet Gynecol Scand 63:345-353

23. Thiringer K, Blomstrand S, Hrbek A, Karlsson K, Kjellmer I 1982 Cerebral arteriovenous difference for hypoxanthine and lactate during graded asphyxia in the fetal lamb. Brain Research 239:107-117

24. de Courten-Myers GM, Kleinholz M, Wagner KR, Myers RE 1989 Fatal stroke in hyperglycemic cats. Stroke 20:1707-1715

25. Kjellmer I, Andine P, Hagberg H, Thiringer K 1989 Extracellular increase of hypoxanthine and xanthine in the cortex and basal ganglia of fetal lambs during hypoxia-ischemia. Brain Res 478:241-247

26. McCord JM 1985 Oxygen-derived free radicals in postischemic tissue injury. $\mathrm{N}$ Engl J Med 312:159-163

27. Vannucci RC 1990 Experimental biology of cerebral hypoxia-ischemia: relation to perinatal brain damage. Pediatr Res 27:317-326

28. Thiringer K. Hrbek A, Karlsson K, Rosen KG, Kjellmer I 1987 Post-asphyxial cerebral survival in newborn sheep after treatment with oxygen free radical scavengers and a calcium antagonist. Pediatr Res 22:62-66

29. Rosenberg AA, Murdaugh E, White CW 1989 The role of oxygen free radicals in postasphyxia cerebral hypoperfusion in newborn lambs. Pediatr Res 26:215-219

30. Cervos-Navarro J, Sampaolo S, Hamdorf G 1991 Brain changes in experimental chronic hypoxia. Exp Pathol 42:205-212

31. Rootwelt T, Loberg EM, Moen A, Oyasaeter S, Saugstad OD 1992 Hypoxemia and reoxygenation with $21 \%$ or $100 \%$ oxygen in newborn pigs: changes in blood pressure, base deficit, and hypoxanthine and brain morphology. Pediatr Res 32:107-1.13

32. Ashwal S, Dale PS, Longo L.D 1984 Regional cerebral blood tlow: studies in the fetal lamb during hypoxia, hypercapnia, acidosis, and hypotension. Pediatr Res 18:13091316

33. Mallard EC. Gunn AJ, Williams CE, Johnston BM, Gluckman PD 1992 Transient umbilical cord occlusion causes hippocampal damage in the fetal sheep. Am J Obstet Gynecol 167:1423-1430

34. Hicks SP 1950 Brain metabolism in vivo. I. The distribution of lesions caused by cyanide poisoning, insulin hypoglycemia, asphyxia in nitrogen and fluoroacetate poisoning in rats. Arch Path 49:111-137

35. Cammermeyer J 1961 The importance of avoiding "dark" neurons in experimental neuropathology. Acta Neuropathol 1:245-270 


\section{Chapter 7}

\section{The T/QRS ratio of the ECG does not reliably reflect well-being in fetal lambs}

Harmen H. de Haan , Anke C.M. LJzermans, Jelte de Haan and Tom H.M. Hasaart

From the Department of Obstetrics and Gynecology,

University Hospital, Maastricht, the Netherlands.

American Journal of Obstetrics and Gynecology 1994; in press 


\section{Abstract}

The objective of the present study was to determine the diagnostic power of the T/QRS ratio of the ECG to predict fetal well-being. Therefore in 47 fetal lambs ( 3 to 5 days after surgery, gestational age $123.5 \pm 3.0$ days) asphyxia was induced by restriction of uterine perfusion. Fetuses were either pretreated with an adenosine transport inhibitor $(n=16)$, treated with a calcium channel blocker $(n=12)$, or served as controls $(n=19)$. An arterial oxygen content $\geq 1.5 \mathrm{mM}$ and/or $p H \geq 7.15$ were chosen as limits for fetal well-being .

The arterial oxygen content was reduced from $3.3( \pm 1.0)$ to $1.3( \pm 0.5)$ $m M, p H$ decreased to $7.03( \pm 0.10)$. Mortality was 53\%. Both drugs did not affect well-being, survival, or the T/QRS ratio. Maximum T/QRS ratios were reached at the peak of asphyxia. Sensitivity and specificity of the T/QRS ratio were $24.0 \%$ and $42.6 \%$ to predict hypoxemia, $25.1 \%$ and $45.3 \%$ to predict acidemia. Pearson correlation coefficients for $T / Q R S$ ratio versus oxygen content and versus $p H$ were 0.169 and 0.192, respectively. It is concluded that: (I) In fetal lambs the T/QRS ratio failed to predict hypoxemia or acidemia. (II) Fetal survival was not correlated with the magnitude of the T/QRS ratio during or after asphyxia. 


\section{Introduction}

Soon after its introduction electronic FHR monitoring became widely used trying to decrease perinatal mortality and morbidity (1). However, after use of cardiotocography (CTG) for two decades it is clear that FHR patterns poorly correlate with fetal acid-base balance (2). Difficulty in the interpretation of CTG patterns during labor can result in unnecessary operative intervention (3) or in damaged neonates (4). Serial sampling of fetal blood enables division of cases with abnormal CTG traces in fetuses with and fetuses without acidemia (5). This technique however is laborious, invasive, and considered unpleasant by patients. Therefore, research is directed toward non-invasive, patient friendly methods of fetal surveillance. Recently the combination of CTG with continuous analysis of the fetal ECG during labor led to reduction of the proportion of operative deliveries for fetal distress, without differences in neonatal outcome (6).

In animal studies the main interest in the fetal ECG has been focused on changes in the ST segment and $\mathrm{T}$ wave. In response to hypoxia the ratio of $\mathrm{T}$ wave height to QRS height (T/QRS ratio) increased in studies in fetal lambs $(7,8,9)$. However, in these studies animals were able to recover from hypoxia without the onset of anaerobic metabolism and the occurrence of acidemia. This differs from clinical pathophysiology, where severity of acidosis is considered an important parameter in determination of the degree of fetal distress (10) and the concomitant fetal morbidity (11).

The current study was designed to induce fetal hypoxemia severe enough to result in anaerobic fetal metabolism and acidemia, which would inevitably be associated with fetal death in some animals. The asphyxial condition was created in 47 fetal lambs by reduction of uterine perfusion. Animals were treated with drugs potentially useful in treatment of asphyxiated fetuses: R-75231 (an adenosine transport inhibitor) (12), flunarizine (a calcium channel blocker) (13), or with the solvent of both drugs. We evaluated the effect of asphyxia and both drugs on the T/QRS ratio of the fetal ECG. Thereafter we calculated the diagnostic potential of the T/QRS ratio to predict fetal hypoxemia or fetal acidemia. To investigate if a change of the T/QRS ratio within an individual animal was indicative for its metabolic condition, linear regression analysis was performed for the T/QRS ratio versus arterial oxygen content and versus $\mathrm{pH}$. Besides the ECG we were interested in hemodynamic variables as $\mathrm{Pa}$ and $\mathrm{Pv}$ and perfusion pressure, possibly indicative for fetal survival.

\section{Material and methods}

\section{Surgery}

Surgery was performed in 47 pregnant Dutch Texel sheep. Gestational ages varied between 110 and 128 days (mean $\pm \mathrm{SD}=120.0 \pm 2.8$ days, term $=147$ days). Instrumentation, handling, and care of the animals were performed as described previously (12). Briefly, a paramedian abdominal incision was made, 
and an inflatable balloon occluder was placed around the maternal common internal iliac artery. Electrodes, made of stranded silver plated copper wire isolated with extruded Teflon, were implanted subcutaneously at the level of the cardiac apex and at both forelegs for recording of the fetal ECG. Catheters were inserted in the fetal axillary and femoral artery, the femoral vein, and in the amniotic cavity. Electrodes and catheters were exteriorized to the ewe's flank.

\section{Measurements}

The fetal ECG leads were placed subcutaneously on the left chest wall at the apex level, and at right and left foreleg. This does not correspond with one of the standard ECG leads. The chest lead was connected to the positive, the leg leads to the negative terminal of the electrocardiograph. These leads would identify changes in the Y-axis, shown to be sensitive in detection of ST waveform changes (14). The fetal ECG was FM tape recorded continuously during the experiment. Recording was performed low pass filtered with a 3 -db limit of $100 \mathrm{~Hz}$. The overall bandwidth was 0.05 to $100 \mathrm{~Hz}$. Analysis of the fetal ECG and determination of T/QRS ratio was performed after all 47 experiments were finished.

Fetal $\mathrm{Pa}$ and $\mathrm{Pv}$ and amniotic pressure were determined with the zero point at the level of the ewe's spine. These signals, together with the FHR derived from the pulsatile signal of the femoral artery, and the fetal ECG, were fed into a bioelectric amplifier (Hewlett-Packard 8800 series, Andover, Mass., USA), displayed on a monitor, recorded on an eight-channel strip chart recorder, stored on magnetic tape, and digitized and analyzed with a computer.

During baseline, at the peak of asphyxia and twice in the recovery phase $2 \mathrm{~mL}$ of blood were withdrawn from the axillary artery and centrifuged ( 3 minutes at 13,000 revolutions/min). Serum was frozen in liquid nitrogen and stored at $-73^{\circ} \mathrm{C}$ to determine lactate concentrations. Blood gas values and $\mathrm{pH}$ from the fetal aortic arch were measured with an automated analyzer (AVL, Radiometer, Copenhagen, Denmark) and corrected for $39^{\circ} \mathrm{C}$. Hb saturation was measured with a hemoximeter (OSM2 Hemoximeter, Radiometer). The $\left[\mathrm{O}_{2}\right]$ a was calculated as follows: $\left[\mathrm{O}_{2}\right] \mathrm{a}(\mathrm{mM})=\mathrm{Hb}$ concentration $(\mathrm{mM}) \times \mathrm{Hb}$ oxygen saturation $(\% / 100)$.

\section{Experiments}

Gestational age at the beginning of experiments varied between 113 and 132 days (mean $\pm \mathrm{SD}=123.5 \pm 3.0$ days). Baseline values for $\mathrm{FHR}$, and $\mathrm{Pa}$ and $\mathrm{Pv}$ were obtained during a control period of 2 hours. Fetal acid-base balance was analyzed every 15 minutes.

Asphyxia was induced by gradual reduction of uterine blood flow by stepwise inflation of the balloon occluder around the maternal common internal iliac artery. To maintain the fetus in a stable hemodynamic condition, uterine blood flow was gradually reduced over a period of 90 to 120 minutes until fetal $\left[\mathrm{O}_{2}\right]$ a was reduced to approximately $35 \%$ of baseline value. This latter hypoxemic 
condition was maintained for 1 hour, during which the $\mathrm{pH}$ dropped. This 1 hour period is referred to as severe asphyxia (time $=0$ to $60 \mathrm{~min}$ ). Serum lactate measurements were performed during baseline condition, at the peak of asphyxia (time $=60 \mathrm{~min}$ ), and 30 minutes and 120 minutes after release of the occluder (at time $=90 \mathrm{~min}$ and time $=180 \mathrm{~min}$ ). Administration of R-75231, flunarizine, or the solvent of both drugs resulted in the formation of three groups, referred to as group $\mathrm{R}$ (R-75231), group F (flunarizine), and group $\mathrm{C}$ (control, animals that received the solvent). During the baseline period group $\mathrm{R}$ ( 16 fetuses) was treated with an intravenous bolus of R-75231 \{2-aminocarbonyl-N-(4-amino-2,6-dichlorophenyl)4-[5,5-bis(4-fluorophenyl)-pentyl]-1-piperazineacetamine $\}$ in a dosage of 0.1 $\mathrm{mg} / \mathrm{kg}$ estimated fetal weight. At random with R-75231, ten fetuses (of group C) received its solvent, being $10 \% 5-\mathrm{OH}$-propyl- $B$-cyclodextrine, at the same moment in the experiment. In group $F$ twelve animals were treated with flunarizine in a dosage of $0.5 \mathrm{mg} / \mathrm{kg}$ estimated fetal weight. At random with flunarizine, nine animals (group C) received the solvent of flunarizine. To avoid possible side effects such as systemic hypotension and tachycardia, we administered flunarizine or the solvent in 2 dosages over a period of 1 hour in the axillary artery. The first dosage was started at time $=60 \mathrm{~min}$, the second dosage was started at time $=180$ min. Because the solvent of flunarizine also consisted of 10\% 5-OH-propyl- $\mathrm{B}$ cyclodextrine both solvent groups were taken together and referred to as control group (C). This solvent has proven to be inert in numerous experiments in animals and man (Janssen Pharmaceutica, personal communication).

The experiment was ended when either the fetus had died or, in case of fetal survival, after 3 days. When still alive after 3 days a relaparotomy was performed under general anesthesia. The fetus was in vivo perfused with a fixative solution to perform histologic analysis of the brain (15).

\section{Calculations and data analysis}

FHR, $\mathrm{Pa}$ and $\mathrm{Pv}$, corrected for amniotic pressure, were averaged over 10 seconds periods using a computer program. Five of these epochs were averaged to calculate mean values. Perfusion pressure was determined every 15 minutes by subtraction of $\mathrm{Pv}$ from $\mathrm{Pa}$.

The FM tape recorded fetal ECG was run through a commercially available cardiotocograph and ECG-analyzer (ST-analyzer, Cinventa AB, Mölndal, Sweden), and analyzed with the aid of a microprocessor system supplied by the same company. The ST-analyzer employs a system of template matching of the QRS complex, followed by signal averaging of accepted complexes, provided an adequate number of complexes are accepted during a set period. Conversion of the fetal ECG was done at a rate of 500 samples per second and with a resolution corresponding to 8 bits (14). The average ECG complex was based on $30 \mathrm{ECG}$ complexes. Filter characteristics and averaging processes were in agreement with recommendations from literature $(9,14)$. 
The diagnostic potential of the T/QRS ratio, as a test to trace fetal compromise, was determined using an $\left[\mathrm{O}_{2}\right]$ a of $1.5 \mathrm{mM}$ as a cut-off level, repeated by the same calculation using a $\mathrm{pH}$ of 7.15 as a cut-off level. To determine if the T/QRS ratio during the experiment was an indication of fetal compromise, linear regression analysis was performed for T/QRS ratio versus $\left[\mathrm{O}_{2}\right] \mathrm{a}$ and for $\mathrm{T} / \mathrm{QRS}$ ratio versus $\mathrm{pH}$ in each individual fetus. Mean slopes and Pearson correlation coefficients were calculated for all groups.

Because we were interested in parameters possibly influencing fetal survival after asphyxia, the groups were divided into survivors $(\mathrm{R}+, \mathrm{F}+$, and $\mathrm{C}+)$ and non-survivors (R-, F-, and $\mathrm{C}$-), thus forming six different groups. Survival was established if the fetus was still alive 12 hours after asphyxia. Differences between groups were tested with the two-tailed Mann-Whitney $U$ test. A $p<0.05$ was accepted as level of statistical significance.

\section{Results}

Twenty-two of the 47 fetal lambs (47\%) survived longer than 12 hours after asphyxia. Table 7.1 shows the number of animals in all 6 groups, mean survival time and the range of survival in each group. The limit for survival was arbitrarily set at 12 hours. Only four animals survived in the range from 6 to 20 hours. Therefore, a change of this limit would not result in major shitts of animals from one group to another.

Table 7.1. Characteristics of the six experimental groups

\begin{tabular}{|l|l|c|c|c|c|}
\hline Group & Treatment & $\begin{array}{c}\text { Survival } \\
\geq 12 \text { hours }\end{array}$ & $\begin{array}{c}\text { Mean } \\
\text { survival }\end{array}$ & $\begin{array}{c}\text { Survival } \\
\text { range }\end{array}$ & $\begin{array}{c}\text { Number of } \\
\text { animals }\end{array}$ \\
\hline R+ & R-75231 & yes & 60.5 & $22-72$ & 8 \\
R- & R-75231 & no & 2.3 & $0.5-11$ & 8 \\
F+ & flunarizine & yes & 51.4 & $13-72$ & 7 \\
F- & flunarizine & no & 2.5 & $1-4.5$ & 5 \\
C+ & control & yes & 43.1 & $12-72$ & 7 \\
C- & control & no & 3.6 & $0.2-10$ & 12 \\
\hline
\end{tabular}

Division of the 47 fetuses used in the current study according to treatment and survival.

Mean survival and survival range are expressed in hours. 


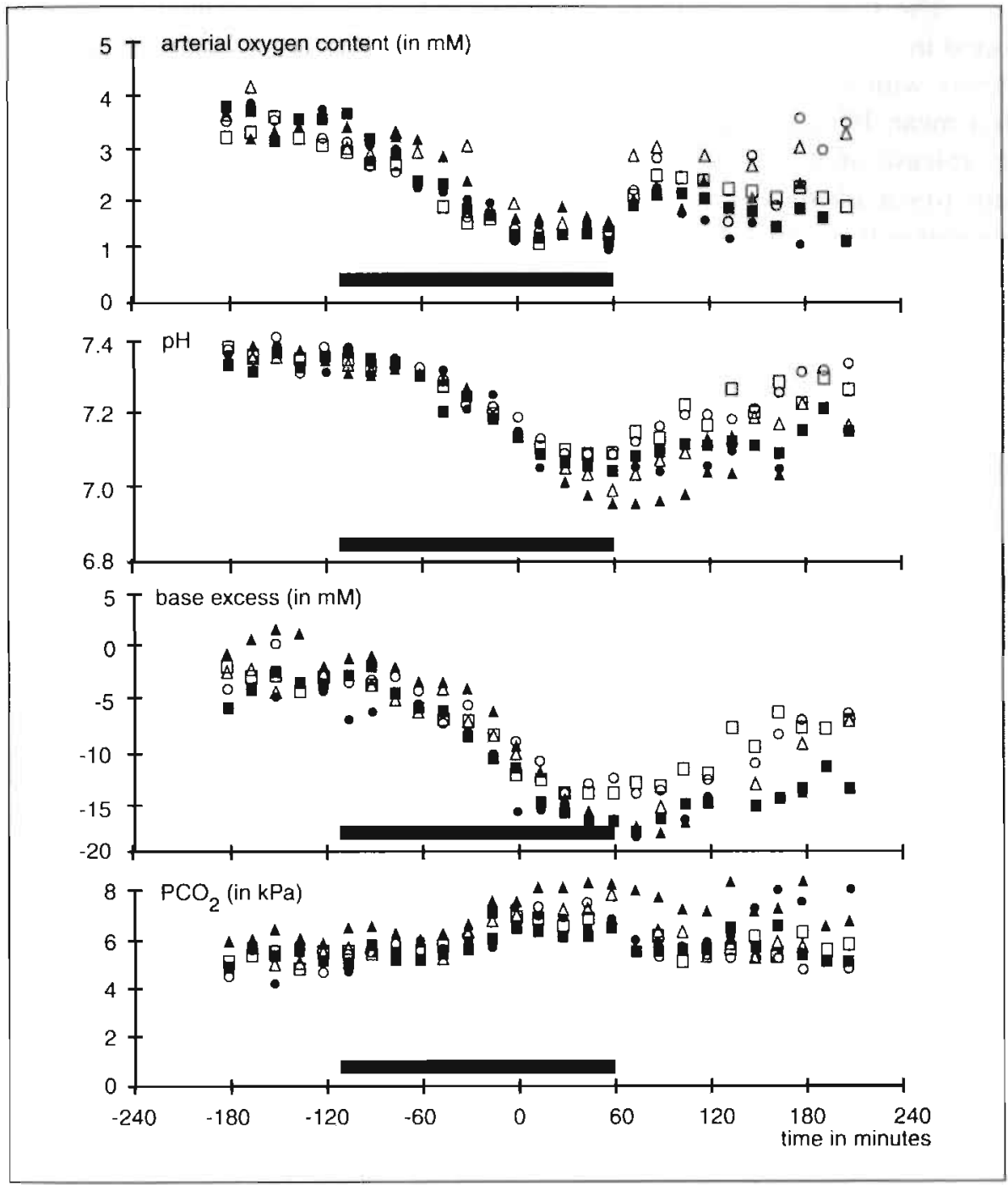

Figure 7.1. Time course of $\left[\mathrm{O}_{2}\right] \mathrm{a}(\mathrm{mM}), \mathrm{pH}, \mathrm{BE}(\mathrm{mM})$, and $\mathrm{PCO}_{2}(\mathrm{kPa})$. Values are means of the six groups: $\mathrm{R}+$ (open triangles), $\mathrm{R}$ - (filled triangles), $\mathrm{F}+$ (open circles), $\mathrm{F}$-(filled circles), $\mathrm{C}+$ (open squares) and $\mathrm{C}$ - (filled squares). Time (min) is depicted on the X-axis; time -180 to $-120 \mathrm{~min}=$ baseline period; time -120 to $0 \mathrm{~min}=$ progressive reduction of uterine blood flow; time 0 to $60 \mathrm{~min}=1$ hour period of asphyxia; time 60 to $210 \mathrm{~min}=$ recovery period. Bar, period of occlusion. 
The time course of the mean metabolic condition of all 6 groups is depicted in Figure 7.1. During the occlusion period the $\left[\mathrm{O}_{2}\right] \mathrm{a}$ decreased, leading to acidemia with a mean $\mathrm{pH}$ of $7.03( \pm 0.10)$ at time $=60 \mathrm{~min}$. This was associated with a mean $\mathrm{BE}$ of $-16.3( \pm 3.8) \mathrm{mM}$. The $\mathrm{PCO}_{2}$ did not increase significantly. After release of the occluder the $\left[\mathrm{O}_{2}\right]$ a immediately increased in the surviving groups (open symbols) leading to $\mathrm{pH}$ values that returned to baseline and to $\mathrm{BE}$ levels within the normal range. This was in contrast with the non-surviving groups (closed symbols): release of the occluder only temporarily led to an increase of $\left[\mathrm{O}_{2}\right] \mathrm{a}$, whereas $\mathrm{pH}$ and $\mathrm{BE}$ did not return to baseline values. No significant differences between groups were demonstrated before and during occlusion, whereas from time $=150$ min onwards $\left[\mathrm{O}_{2}\right] \mathrm{a}, \mathrm{pH}$ and $\mathrm{BE}$ values were higher in the surviving groups compared with the non-surviving groups $(p<0.05$, two-tailed Mann-Whitney U test).

Serum lactate levels increased during asphyxia and remained elevated after release of the occluder in the non-surviving animals (Table 7.2). This was in contrast with the surviving fetuses. where a decrease of lactate levels was seen in the recovery period.

Table 7.2. Serum lactate levels (mean $\pm S D . m M$ )

\begin{tabular}{|c|c|c|c|c|}
\hline Group & Baseline & Asphyxia & time $=90 \mathrm{~min}$ & time $=180 \mathrm{~min}$ \\
\hline $\mathrm{R}+$ & $1.6 \pm 1.3$ & $14.2 \pm 2.0$ & $14.2 \pm 1.6$ & $11.5 \pm 1.8$ \\
\hline $\mathrm{R}-$ & $1.3 \pm 0.4$ & $14.1 \pm 3.0$ & $14.8 \pm 3.4$ & $12.2(\mathrm{n}=1)$ \\
\hline $\mathrm{F}+$ & $1.4 \pm 0.4$ & $14.0 \pm 3.5$ & $11.5 \pm 2.8$ & \pm 3.2 \\
\hline F- & $1.8 \pm 0.9$ & $12.1 \pm 7.0$ & $13.4 \pm 7.4$ & \pm 6.0 \\
\hline$C+$ & $1.4 \pm 0.6$ & $11.9 \pm 4.3$ & $11.7 \pm 4.5$ & \pm 3.7 \\
\hline $\mathrm{C}-$ & $2.0 \pm 1.3$ & $12.1 \pm 3.7$ & $11.0 \pm 2.9$ & \pm 5.4 \\
\hline
\end{tabular}

Asphyxia is at time $=60 \mathrm{~min}$. at the peak of asphyxia. Time $=90 \mathrm{~min}$ and time $=180 \mathrm{~min}$ corresponds with 0.5 and 2 hours after release of the occluder, respectively.

Figure 7.2 shows the time course of fetal cardiovascular parameters. During asphyxia and recovery the FHR increased slightly in all groups, mean $\mathrm{Pa}$ and Pv did not significantly change, nor did the perfusion pressure (Pa-Pv). Differences between groups were not significant (two-tailed Mann-Whitney U test). 

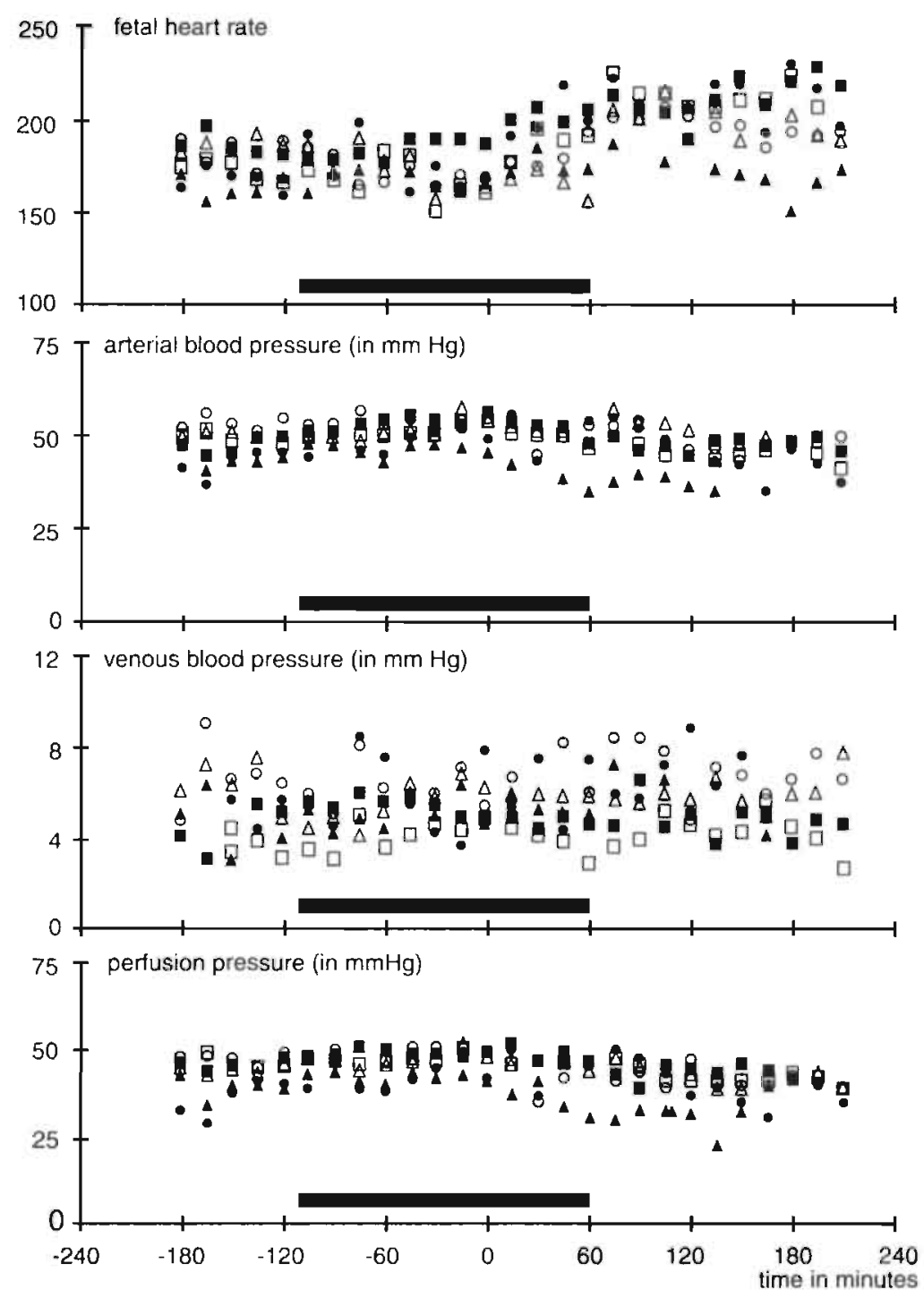

Figure 7.2. Time course of FHR, $\mathrm{Pa}(\mathrm{mm} \mathrm{Hg}$ ), Pv ( $\mathrm{mm} \mathrm{Hg}$ ), and perfusion pressure (Pa$\mathrm{Pv}, \mathrm{mm} \mathrm{Hg}$ ). Values are means of the six groups: $\mathrm{R}+$ (open triangles). $\mathrm{R}$-(filled triangles), $\mathrm{F}+$ (open circles), $\mathrm{F}$ - (filled circles), $\mathrm{C}+$ (open squares) and $\mathrm{C}$ - (filled squares). Time (min) is depicted on the $\mathrm{X}$-axis; time -180 to $-120 \mathrm{~min}=$ baseline period; time -120 to $0 \mathrm{~min}=$ progressive reduction of uterine blood flow; time 0 to $60 \mathrm{~min}=1$ hour period of asphyxia; time 60 to $210 \mathrm{~min}=$ recovery period. Bar, period of occlusion. 
The mean T/QRS ratio for all 6 groups is shown in Figure 7.3. The mean increased during occlusion, maximum levels were reached at time $=60 \mathrm{~min}$, at the peak of asphyxia. Standard deviations are depicted for the control groups $(\mathrm{C}+$ and $\mathrm{C}$-), solely to indicate the large interanimal variation. Due to this variation significant differences between groups were not reached. The two drugs used in the present study (R-75231 and flunarizine) did not affect the T/QRS ratio. Surviving fetuses did not have different T/QRS values compared with nonsurviving fetuses.

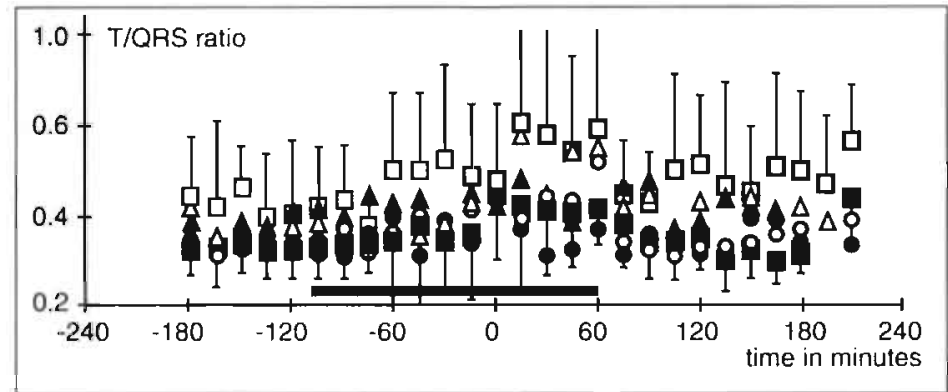

Figure 7.3. Time course of the $T / Q R S$ ratio. Values are means of the six groups: $R+$ (open triangles), $\mathrm{R}$ - (filled triangles), $\mathrm{F}+$ (open circles), F- (filled circles), $\mathrm{C}+$ (open squares) and C- (filled squares). Time ( $\mathrm{min}$ ) is depicted on the $\mathrm{X}$-axis; time -180 to $-120 \mathrm{~min}=$ baseline period; time -120 to $0 \mathrm{~min}=$ progressive reduction of uterine blood flow: time 0 to $60 \mathrm{~min}=$ 1 hour period of asphyxia; time 60 to $210 \mathrm{~min}=$ recovery period. Bar, period of occlusion. Standard deviations are depicted for the control group ( $\mathrm{C}+$ and $\mathrm{C}-$ ), only to indicate interanimal variability.

To determine the diagnostic possibilities of the T/QRS ratio we related all T/QRS values with their concomitant $\mathrm{pH}$ and $\left[\mathrm{O}_{2}\right]$ a value. From the resulting scattergram, the accuracy could be determined. All T/QRS ratios and $\mathrm{pH}$ data for group $\mathrm{C}+$ are shown in Figure 7.4. The diagnostic potential of the T/QRS ratio was determined based on the cut-off levels T/QRS $\leq 0.25,0.25 \leq \mathrm{T} / \mathrm{QRS} \leq 0.50$, and $T / Q R S>0.50$. These cut-off levels created 6 cells (a-f, depicted in Figure 7.4), which were used to calculate the diagnostic potential of the T/QRS ratio in predicting fetal hypoxemia $\left(\left[\mathrm{O}_{2}\right] \mathrm{a}<1.5 \mathrm{mM}\right)$ or fetal acidemia $(\mathrm{pH}<7.15)$. The results of these calculations are shown in Table 7.3. Calculations were based on 787 data-pairs regarding $\mathrm{T} / \mathrm{QRS}$ ratio and $\left[\mathrm{O}_{2}\right] \mathrm{a}$, and on 776 data-pairs regarding T/QRS ratio and $\mathrm{pH}$. Results were poor; sensitivity and specificity were low, predictive values moderate, and likelihood ratios for both a positive and a negative test result were poor. 
Whereas in Figure 7.4 the linear regression analysis of the T/QRS ratio versus the $\mathrm{pH}$ of group $\mathrm{C}+$ is shown $(\mathrm{y}=-0.767 \mathrm{x}+6.011, \mathrm{r}=-0.346)$, the mean slopes and the Pearson correlation coefficients of all 6 groups are summarized in Table 7.4. Except for group R- (T/QRS versus $\mathrm{pH}$ ) all slopes were negative. Correlation coefficients were low. Differences between groups did not reach significance. Since differences between groups were not significant all animals were taken together in the regression analysis of T/QRS ratio versus serum lactate levels. Lactate was determined at 4 moments during the experiment in 47 animals (188 samples), whereas in 156 cases an adequate T/QRS ratio was obtained during sampling. Regression analysis on these 156 data-pairs showed $y=0.008 x+0.267$, $r=0.227$.

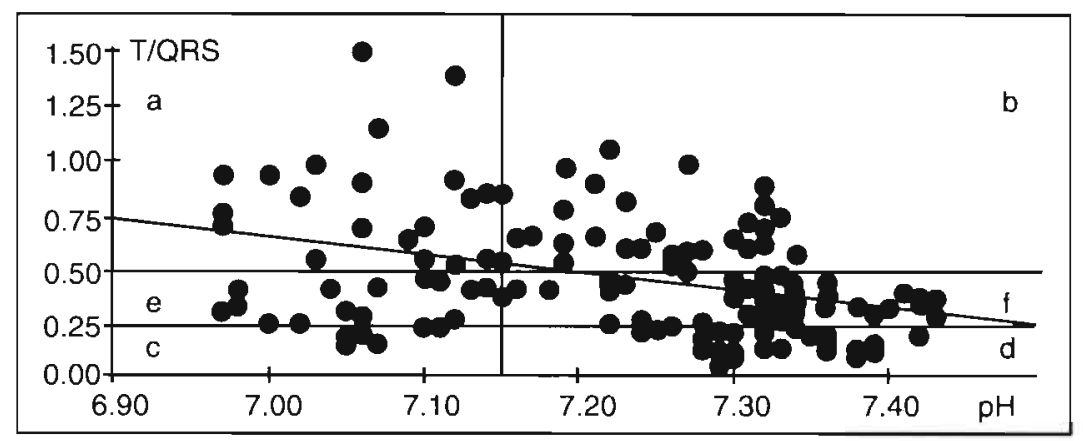

Figure 7.4. Scattergram depicting all available combinations of $T / Q R S$ ratio and $\mathrm{pH}$ of group $C+$. The linear regression line $(y=-0.767 x+6.011, r=-0.346)$ is shown, horizontal lines indicate cut-off levels for determination of accuracy of the T/QRS ratio. As a result of these lines six cells are formed (a-f), corresponding with the cells of Table 7.3.

Table 7.4. Regression analysis for the T/QRS ratio versus $\left[\mathrm{O}_{2}\right] \mathrm{a}$ and of the T/QRS ratio versus $\mathrm{pH}$

\begin{tabular}{|l|c|c|c|c|}
\hline Group & \multicolumn{2}{|c|}{ T/QRS versus arterial oxygen content } & \multicolumn{2}{|c|}{ T/QRS versus $\mathrm{pH}$} \\
\hline & mean slope & $\begin{array}{c}\text { correlation } \\
\text { coefficient }\end{array}$ & mean slope & $\begin{array}{c}\text { correlation } \\
\text { coefficient }\end{array}$ \\
\hline R+ & -0.040 & -0.220 & -0.757 & -0.446 \\
R- & -0.029 & -0.152 & 0.175 & 0.145 \\
F+ & -0.018 & -0.108 & -0.247 & -0.185 \\
F- & -0.024 & -0.197 & -0.133 & -0.172 \\
C+ & -0.026 & -0.091 & -0.767 & -0.346 \\
C- & -0.040 & -0.247 & -0.199 & -0.150 \\
\hline
\end{tabular}

Values are expressed as mean. Differences between groups did not reach significance. 


\section{Discussion}

Reduction of maternal uterine perfusion with an inflatable balloon occluder resulted in decreased fetal $\left[\mathrm{O}_{2}\right] \mathrm{a}$, the onset of anaerobic metabolism, production of lactate, and a decrease in $\mathrm{pH}$. BE dropped, and the fetuses kept their $\mathrm{PCO}_{2}$ reasonably constant. Asphyxia induced in this group of 47 fetuses was considered severe, as the estimated extracellular fluid BE was always less, and often far less, than $-12 \mathrm{mM}$ (16). Moreover, the severity of asphyxia was indicated by a mortality within 12 hours after the asphyxial event of 53\% ( 25 of 47 animals).

During the experiment FHR increased, mean Pa and Pv as well as perfusion pressure remained unaltered.

In previous experiments the beneficial effect of R-75231 on fetal cardiovascular functioning after asphyxia was demonstrated (12). Therefore, 16 animals were pretreated with R-75231 in the current study. The rationale to treat 12 fetuses with the calcium channel blocker flunarizine is its effect regarding reduction of cerebral morbidity after hypoxic-ischemic events (17). Calcium shifts occurring with severe energy failure are responsible for massive calcium overload in neurons, leading to the activation of phospholipases. This results in accumulation of free fatty acids and in edema of neurons, which further compromises oxygen supply (18).

The major finding of the current study was the fact that the T/QRS ratio of the ECG did not reflect well-being in fetal lambs. This was mainly attributable to the large interanimal variation (Figure 7.3), not only during asphyxia but also during the normoxemic baseline period. The trend of the T/QRS ratio in individual animals may be a better indicator of fetal well-being. Therefore, we performed a linear regression analysis of T/QRS ratio versus $\left[\mathrm{O}_{2}\right]$ a and versus $\mathrm{pH}$. All 47 asphyxiated fetuses were categorized according to treatment and survival in one of the 6 groups. Pearson correlation coefficients of the 6 groups were low and differences between groups were not significant (Table 7.4). We conclude that within a particular animal a change of T/QRS ratio did not correlate satisfactorily either with its metabolic condition or with its survival.

Recently, a new CTG monitor was designed to combine the CTG with an on-line calculation of the T/QRS ratio during labor (19). The first randomized trial of this ST waveform analysis during labor seemed promising. The rate of operative deliveries for fetal distress was reduced by $53 \%$ and the use of cesarean section and rotational forceps was reduced by $74 \%$, without changes in neonatal outcome (6). However, also recent literature is not unequivocal. None of the neonates born in a poor condition (one minute Apgar score $\leq 3$ ) or with evidence of acidemia had a mean T/QRS ratio significantly different from the normal range (20). A raised $T / Q R S$ ratio had a considerably lower detection rate for fetal acidemia than a pathological CTG (21), and a weak correlation was found between the T/QRS ratio and umbilical artery acidemia (22). 
Table 7.3. Diagnostic value of the $T / Q R S$ ratio

\begin{tabular}{|c|c|c|c|c|c|c|}
\hline T/QRS ratio & $\begin{array}{l}{\left[\mathrm{O}_{2}\right] \mathrm{a}} \\
<1.5 \mathrm{mM}\end{array}$ & $\begin{aligned} & 1 \mathrm{O}_{2} \mathrm{Ja} \\
\geq & 1.5 \mathrm{mM}\end{aligned}$ & \multicolumn{2}{|c|}{$\mathrm{pH}<7.15$} & \multicolumn{2}{|c|}{$\mathrm{pH} \geq 7.15$} \\
\hline$>0.50$ & 58 (a) & 88 (b) & \multicolumn{2}{|c|}{75 (a) } & \multicolumn{2}{|c|}{68 (b) } \\
\hline$<0.25$ & 89 (c) & 232 (d) & \multicolumn{2}{|c|}{102 (c) } & \multicolumn{2}{|c|}{$216(d)$} \\
\hline $0.25 \leq \mathrm{T} / \mathrm{QRS} \leq 0.50$ & $95(\mathrm{e})$ & $225(\mathrm{f})$ & \multicolumn{2}{|c|}{122 (e) } & \multicolumn{2}{|c|}{193 (f) } \\
\hline & & & & \multicolumn{2}{|c|}{ hypoxemia } & acidemia \\
\hline Positive predictive value & \multicolumn{3}{|l|}{$=a /(a+b)$} & \multicolumn{2}{|c|}{$=39.7 \%$} & $52.4 \%$ \\
\hline Negative predictive value & \multicolumn{3}{|l|}{$=\mathrm{d} /(\mathrm{c}+\mathrm{d})$} & \multicolumn{2}{|c|}{$=72.3 \%$} & $67.9 \%$ \\
\hline Sensitivity & \multicolumn{3}{|c|}{$=\mathrm{a} /(\mathrm{a}+\mathrm{c}+\mathrm{e})$} & \multicolumn{2}{|c|}{$=24.0 \%$} & $25.1 \%$ \\
\hline Specificity & \multicolumn{3}{|c|}{$=d /(b+d+f)$} & \multicolumn{2}{|c|}{$=42.6 \%$} & $45.3 \%$ \\
\hline False positive rate & \multicolumn{3}{|c|}{$=b /(b+d+f)$} & \multicolumn{2}{|c|}{$=16.1 \%$} & $14.3 \%$ \\
\hline False negative rate & \multicolumn{3}{|c|}{$=c /(a+c+e)$} & \multicolumn{2}{|c|}{$=36.8 \%$} & $34.1 \%$ \\
\hline Accuracy & \multicolumn{3}{|c|}{$=(a+d) /(a+b+c+d+e+f)$} & \multicolumn{2}{|c|}{$=36.8 \%$} & $37.5 \%$ \\
\hline Prevalence & \multicolumn{3}{|c|}{$=(a+c+e) /(a+b+c+d+e+f)$} & \multicolumn{2}{|c|}{$=30.7 \%$} & $38.5 \%$ \\
\hline \multicolumn{4}{|c|}{ Likelihood ratio for a positive test result } & \multirow{3}{*}{\multicolumn{2}{|c|}{1.49}} & \\
\hline & ensitivity/false & itive rate $)=$ & & & & 1.76 \\
\hline \multicolumn{4}{|c|}{ Likelihood ratio for a negative test result } & & & \\
\hline & alse negative $\mathrm{r}$ & specificity) & & \multicolumn{2}{|c|}{0.86} & 0.75 \\
\hline
\end{tabular}

The diagnostic value of the T/QRS ratio as determined in all fetal lambs $(n=47)$ irrespective of their treatment. The diagnostic value was determined for fetal hypoxemia and for fetal acidemia with cut-off levels for $\left[\mathrm{O}_{2}\right] \mathrm{a}<1.5 \mathrm{mM}$ and for $\mathrm{pH}<7.15$, respectively. The numbers in the 6 cells (a-f) reflect the number of times a particular T/QRS ratio was associated with a certain metabolic condition.

Increment of the T/QRS ratio in animal experiments was suggested to represent a change to anaerobic myocardial metabolism (7), secondary to betaadrenergic stimulation (8). The T/QRS ratio may therefore be a parameter by which myocardial adaptation to hypoxia, or a compromized fetus, could be identified. However, no severely asphyxiated fetuses were observed in the latter two animal studies. Moreover, these studies were performed using reduction of the maternal inspired oxygen concentration to induce fetal oxygen shortage. The correlation between elevation of the T/QRS ratio and the rise of plasma lactate levels was based on 5 mildly hypoxic fetal lambs (7). This correlation was not confirmed in the 47 severely asphyxiated fetuses of the present study $(r=0.227)$. Another difference in experimental setup is the gradual induction of fetal asphyxia in the current study, maintaining a normal fetal heart rate and a stable blood pressure. This is in contrast with the bradycardia and marked hypertension observed after maternal occlusion for 60 seconds. which was associated with an increased T/QRS ratio in mature as well as in immature lambs (9). The cause of the raised T/QRS ratio during this cardiovascular instability remains unclear. The 
degree of asphyxia, the cardiovascular stability, and the number of animals studied are the main differences with the present experiments. These severely asphyxiated fetuses represent the group of major interest since this group is highly susceptible for the development of neurologic sequelae (11).

Mean ( \pm SD) values for the T/QRS ratio of the fetal ECG during human labor have been reported as $0.20( \pm 0.11)(23)$ and as $0.10( \pm 0.05)(24)$. The normal range in fetal sheep was reported below 0.30 (7). In the current study the diagnostic potential of the T/QRS ratio was determined based on the cut-off levels recommended: $\mathrm{T} / \mathrm{QRS}<0.25,0.25 \leq \mathrm{T} / \mathrm{QRS} \leq 0.50$, and $\mathrm{T} / \mathrm{QRS}>0.50$. These levels were also used in a large randomized trial of CTG alone or with ST waveform analysis (6) and in sheep experiments (25). Figure 7.4 depicts all available combinations of $\mathrm{T} / \mathrm{QRS}$ ratio and $\mathrm{pH}$ of group $\mathrm{C}+$, the group that had onc of the hest correlation coefficients observed $(\mathrm{r}=-0.346)$. To increase the power of the T/QRS ratio in predicting fetal acidemia the number of observations in cell "a" and cell "d" has to be as large as possible, in cell "b" and cell "c" as small as possible. However, observations are equally spread in the scattergram. Neither a change of $\mathrm{T} / \mathrm{QRS}$ ratio cut-off levels, nor a change of the $\mathrm{pH}=7.15$ or $\left[\mathrm{O}_{2}\right] \mathrm{a}=1.5$ $\mathrm{mM}$ cut-off level will lead to more values in cell "a" and cell " $\mathrm{d}$ ". Therefore, a change of these cut-off levels will not have a major impact on the power of the test. During decelerations induced by umbilical cord compression in fetal sheep the T/QRS ratio was tested in predicting fetal acidemia $(\mathrm{pH}<7.15)$ : sensitivity and specificity reached $100 \%$ and $76.5-87.5 \%$, respectively. Calculations however were based on 22 data-pairs in 5 chronically instrumented animals only, whereas the effect of the deceleration itself remained unclear (25).

The ST-analyzer used in the present study was identical with the one used in recent investigations $(6,21,22)$. Filter and processing characteristics were as recommended $(9,14)$. Cut-off levels used for calculations were selected according literature, and a change of these levels would not induce major improvements of the test. The main differences between studies promoting the T/QRS ratio as a sensitive detector of fetal compromise and the present study are the severity of acidemia, the amount of animals studied, the number of observations per animal, and the method used to induce fetal oxygen shortage.

Whether fetal ECG analysis is superior to the CTG in predicting hypoxemia or acidemia during decelerations in the fetal heart rate pattern in human labor, can of course not be concluded from the current data. Earlier animal studies showed that short lasting acute hypoxia as occurring during decelerations is reflected in the T/QRS ratio $(7,8,9)$. However, in the present study slowly developing fetal acidemia without major changes in heart rate or blood pressure was not adequately detected by ST waveform analysis. The huge increase (up to $400 \%$ ) in myocardial blood flow during the developing acidemia (12), and the concomitant increase in oxygen delivery to the fetal heart may have ensured adequate oxygen delivery to the myocardial cells. thus not leading to ST-waveform changes. 
In conclusion, the present data show that during normoxemia there is a large variation in T/QRS ratio in preterm fetal lambs. During severe asphyxia the mean $\mathrm{T} / \mathrm{QRS}$ ratio increased. However, the prediction of hypoxemia or acidemia on the basis of the T/QRS ratio failed in the fetal lamb model used in this study. Similarly, the correlations between the T/QRS ratio and arterial oxygen content, arterial $\mathrm{pH}$, and serum lactate levels were poor, implying that trends in individual animals were of limited value.

\section{Acknowledgments}

The authors thank May Bost and Joyce Suyk for their animal care and assistance during surgery, Carla M. Verkeste, $\mathrm{PhD}$ for her help in performing statistical analysis, Maurits C.E.F. Wijffels, MD for his help during the analysis of the fetal ECG, and Janssen Pharmaceutica, Beerse. Belgium for donation of drugs and supplementary technical assistance.

\section{References}

1. Caldeyro-Barcia R. Méndez-Bauer C, Poseiro JJ, Escarcena LA, Posé V, Biennarz J, Arnt I, Gulin L, Althabe O 1966 Control of human fetal heart rate during labor. In: Cassels DE (cd) The heart and circulation in newborn and infant. New York: Grune and Stratton Inc., pp 7-36

2. Sykes GS, Molloy PM, Johnson P, Stirrat GM, Turnbull AC 1983 Fetal distress and the condition of newborn infants. Br Med J 287:943-945

3. Haverkamp AD, Orleans M, Langerdörfer S, McFee J, Murphy J, Thompson H 1979 A controlled trial of the differential effects of intrapartum fetal monitoring. Am J Obstet Gynecol 134:399-408

4. Murphy KW, Johnson P, Moorcraft J, Pattinson R, Russell V, Turnbull A 1990 Birth asphyxia and the intrapartum cardiotocograph. Br J Obstet Gynaecol 97:470-479

5. Saling E, Schneider D 1967 Biochemical supervision of the fetus during labour. J Obstet Gynaecol Br Commonw 74:799-811

6. Westgate J, Harris M, Curnow JSH, Greene KR 1993 Plymouth randomized trial of cardiotocogram only versus ST waveform plus cardiotocogram for intrapartum monitoring in 2400 cases. Am J Obstet Gynecol 169:1151-1160

7. Greene KR, Dawes GS, Lilja H, Rosen KG 1982 Changes in the ST waveform of the fetal lamb electrocardiogram with hypoxemia. Am J Obstet Gynecol 144:950-958

8. Rosen KG, Dagbjartsson A. Henriksson BÅ, Lagercrantz H. Kjellmer I 1984 The relationship between circulating catecholamines and $\mathrm{ST}$ waveform in the fetal lamb electrocardiogram during hypoxia. Am J Obstet Gynecol 149:190-195

9. Widmark C, Hökegård KH, Lagercrantz H, Lilja H, Rosen KG 1989 Electrocardiographic waveform changes and catecholamine responses during acute hypoxia in the immature and mature fetal lamb. Am J Obstet Gynecol 160:1245-1250

10. Parer JT, Livingston EG 1990 What is fetal distress? Am J Obstet Gynecol 162: 14211427 
11. Low JA, Galbraith RS, Muir DW, Killen HL, Pater EA, Karchmar EJ 1988 Motor and cognitive deficits after intrapartum asphyxia in the mature fetus. Am J Obstet Gynecol 158:356-361

12. de Haan HH, de Haan J, Van Reempts JLH, Van Belle H. Hasaart THM 1993 The effect of adenosine transport inhibition on cardiovascular tunction and survival after severe asphyxia in fetal lambs. Pediatr Res 33:185-189

13. de Haan HH, Van Reempts JLH, Borgers M, de Haan J, Vles JSH, Hasaart THM 1993 Possible neuroprotective properties of flunarizine intused after asphyxia in fetal lambs are not explained by effects on cerebral blood flow or systemic blood pressure. Pediatr Res 34:379-384

14. Lindecrantz KG, Lilja H, Widmark C, Rosen KG 1988 Fetal ECG during labour: a suggested standard. J Biomed Eng 10:351-353

15. de Haan HH, Van Reempts JLH, Vles JSH, de Haan J, Hasaart THM 1993 Effects of asphyxia on the fetal lamb brain. Am J Obstet Gynecol 169:1493-1501

16. Siggaard-Andersen O 1971 An acid-base chart for arterial blood with normal and pathophysiological reference areas. Scand J Clin Lab Invest 27:239-245

17. Gunn AJ, Mydlar T, Bennet L, Faull RLM, Gorter S, Cook C, Johnston BM, Gluckman PD 1989 The neuroprotective actions of a calcium channel antagonist, flunarizine, in the infant rat. Pediatr Res 25:573-576

18. Siesjö BK 1981 Cell damage in the brain: a speculative synthesis. J Cereb Blood Flow Metab 1:155-185

19. Rosen KG, Lindecrantz K 1989 STAN-the Gothenburg model for fetal surveillance during labor by ST analysis of the fetal electrocardiogram. Clin Phys Physiol Meas 10, suppl B: $51-56$

20. Newbold S, Whecler T, Clewlow F 1991 Comparison of the T/QRS ratio of the fetal electrocardiogram and the fetal heart rate during labour and the relation of these variables to condition at delivery. Br J Obstet Gynaecol 98:173-178

21. McLachlan NA, Spencer JAD, Harding K, Arulkumaran S 1992 Fetal acidaemia, the cardiotocograph and the T/QRS ratio of the fetal ECG in labour. $\mathrm{Br} J$ Obstet Gynaecol 99:26-31

22. Murphy KW, Russell V, Johnson P, Valente J 1992 Clinical assessment of fetal electrocardiogram monitoring in labour. Br J Obstet Gynaecol 99:32-37

23. Lilja H, Greene KR, Karlsson K, Rosen KG 1985 ST waveform changes of the fetal electrocardiogram during labour- a clinical study. Br J Obstet Gynaecol 92: 61 1-617

24. Newbold S, Wheeler $T$, Clewlow F, Soul F 1989 Variation in the T/QRS ratio of fetal electrocardiograms recorded during labour in normal subjects. Br J Obstet Gynaecol 96: 144-150

25. Watanabe T, Okamura K, Tanigawara S, Shiutaku Y, Akagi K, Endo H, Yajima A 1992 Change in electrocardiogram T-wave amplitude during umbilical cord compression is predictive of fetal condition in sheep. Am J Obstet Gynecol 166:246255 


\section{Chapter 8}

\section{Effects of surgery and asphyxia on levels of nucleosides, purine bases, and lactate in cerebrospinal fluid of fetal lambs}

Harmen H. de Haan a , Anke C.M. IJzermans a , Jelte de Haan ${ }^{\text {a }}$, Herman Van Belle ${ }^{b}$ and Tom H.M. Hasaart ${ }^{a}$

From the Department of Obstetrics and Gynecology.

University Hospital, Maastricht, the Netherlands ${ }^{\text {a }}$,

and the Department of Biochemistry,

Janssen Research Foundation, B-2340 Beerse, Belgium ${ }^{\mathrm{b}}$.

Pediatric Research 1994; in press 
Abstract

During severe oxygen shortage the fetal brain resorts to anaerobic metabolism and ATP becomes catabolized. High levels of nucleosides, hypoxanthine and xanthine (ATP catabolites) in cerebrospinal fluid (CSF) may therefore be associated with increased neonatal neurologic morbidity. In 22 fetal lambs ( 3 to 5 days after surgery, gestational age $123.5 \pm 3.5$ days) arterial oxygen content was progressively reduced to $35 \%$ of the baseline value with a balloon occluder around the maternal common internal iliac artery. This resulted in a 1 hour lasting period of asphyxia, leading to a pH of $7.02 \pm 0.03$ and a $\mathrm{BE}$ of -17.0 $\pm 1.0 \mathrm{mM}$. Mortality was $50 \%$. CSF was sampled from the spinal cistern and analyzed using HPLC. During reoxygenation hypoxanthine and xanthine may serve as substrate for xanthine-oxidase with concomitant production of oxygen derived free radicals, which may aggravate cerebral damage. The main difference between surviving and non-surviving animals was the rate of the rise of ATP catabolites in CSF: in the surviving group levels increased steadily, recovery values being significantly elevated compared to asphyxia values, whereas in the non-surviving group the rise was rapid and levels during asphyxia did not differ from levels during recovery. We conclude (I) that catheterization of the spinal cistern leads to increased levels of CSF hypoxanthine, xanthine, and inosine, and (II) that during fetal asphyxia levels of these ATP catabolites and lactate in CSF increase. (III) Maximum levels are reached during the recovery period and are similar for surviving and non-surviving animals, but during asphyxia CSF levels of hypoxanthine and lactate were higher in the non-surviving fetuses. (IV) The rate of rise of ATP catabolites in CSF is higher in the non-surviving animals, and may therefore be predictive for fetal demise. 


\section{Introduction}

Intrauterine oxygen shortage leads to anaerobic fetal metabolism. Due to an increase of CBF (1) and preferential streaming of well-oxygenated blood in the heart (2), the fetal cerebrum is provided with as much oxygen as possible. During severe or sustained oxygen shortage however, the brain too resorts to anaerobic metabolism. Lack of oxygen impairs mitochondrial functioning, leading to energy shortage (3); ATP becomes degraded to AMP and after dephosphorylation, further to adenosine, inosine and hypoxanthine. Serum levels of hypoxanthine are considered a sensitive indicator of the hypoxic insult (4). Moreover, formation of hypoxanthine and xanthine may aggravate outcome after such an insult, because during reoxygenation hypoxanthine and xanthine may act as substrate for the enzyme xanthine-oxidase, yielding oxygen derived free radicals and subsequent damage in the newborn (5). This may explain bronchopulmonary dysplasia in the preterm, since levels of pulmonary free radical scavengers are low in preterm animals and reach peak values around term (6). Since the intestine is known to contain large amounts of xanthine-oxidase (5), and the vitreous corpus of the eye large amounts of hypoxanthine, necrotizing enterocolitis and retinopathy of prematurity may be a result of oxygen derived free radical formation ton (4).

Regarding the brain, oxygen derived free radical scavengers prevent the secondary cerebral hypoperfusion after asphyxia in neonatal lambs (7), and limit perinatal postasphyxial brain damage in rats (8). We measured levels of lactate, adenosine, inosine, guanosine, hypoxanthine, xanthine, and of uric acid in CSF of fetal lambs during surgery, and before, during, and after severe asphyxia induced 3 to 5 days after surgery. We hypothesize that the level of ATP catabolites, and especially of hypoxanthine. in the fetal lamb brain may affect outcome after asphyxia, due to the subsequent oxygen derived free radical production. Therefore, levels of ATP catabolites in CSF of surviving fetuses were compared with levels in non-surviving animals.

\section{Material and methods}

\section{Surgery}

Surgery was performed in 47 pregnant Dutch Texel sheep under general anesthesia. Gestational age varied between 110 and 128 days (mean $\pm \mathrm{SD}=119.9$ \pm 2.7 days, term $=147$ days). Instrumentation, handling, and care of animals was performed as described previously (9). Briefly, a paramedian abdominal incision was made, and an inflatable balloon occluder was placed around the maternal common internal iliac artery. A hysterotomy was performed and the fetus partly extracted. A midline incision was made in the dorsal surface of the fetal neck, and the epidural cavity was opened (10). Epidural fat, containing small veins, was carefully swept away with a cotton-tipped applicator and the spinal cavity was opened with a needle. The appearing CSF was sampled. A polyvinyl catheter (outer diameter $1.6 \mathrm{~mm}$, inner diameter $0.8 \mathrm{~mm}$ ) was inserted through the puncture 
hole into the spinal cavity and advanced 1.0 to $2.0 \mathrm{~cm}$ cranially until adequate CSF sampling was possible. The catheter was fixed with tissue glue and sutured to the fetal skin. The tip of the catheter was located in the spinal cistern. Furthermore, catheters were inserted in the fetal axillary and femoral artery, the femoral vein, and in the amniotic cavity. Electrodes to measure the fetal ECG and ECoG were placed. Electrodes and catheters were exteriorized to the ewe's flank.

\section{Measurements}

The CSF catheter deadspace was reduced to approximately $0.2 \mathrm{~mL}$. The volume obtained per sample was $\geq 0.6 \mathrm{~mL}$, including the deadspace volume. All CSF samples (included the ones obtained during surgery) were withdrawn with a 1 $\mathrm{mL}$ syringe, centrifuged ( 3 minutes at 13,000 revolutions/min), frozen in liquid nitrogen, and stored at $-73^{\circ} \mathrm{C}$. After storage all samples were analyzed simultanuously. Concentrations of lactate were measured using an enzymatic procedure. Levels of nucleosides and bases were determined using high performance liquid chromatography (11).

Blood gas values and $\mathrm{pH}$ from the fetal aortic arch were measured with an automated analyzer (AVL, Radiometer, Copenhagen, Denmark) and corrected for $39^{\circ} \mathrm{C}$. Hb saturation was measured with an hemoximeter (OSM2 Hemoximeter, Radiometer). The $\left[\mathrm{O}_{2}\right]$ a was calculated as follows: $\left[\mathrm{O}_{2}\right] \mathrm{a}(\mathrm{mM})=\mathrm{Hb}$ concentration $(\mathrm{mM}) \times \mathrm{Hb}$ oxygen saturation $(\% / 100)$. During baseline, at the peak of asphyxia, and twice in the recovery period $2 \mathrm{~mL}$ of blood were withdrawn from the axillary artery and centrifuged ( 3 minutes at 13,000 revolutions $/ \mathrm{min}$ ). Serum was frocen in liquid nitrogen and stored at $-73^{\circ} \mathrm{C}$ to determine lactate concentrations.

\section{Experiments}

Fortyseven fetuses were instrumented with a CSF catheter. In 15 animals CSF sampling could only be performed one to four times. Due to this low frequency of sampling changes due to the experiment might be missed, and therefore these fetuses were excluded, together with 10 preparations in which fetal demise in the first 3 days following surgery occurred. Gestational age of the remaining 22 fetuses during experiments varied between 113 and 132 days (mean $\pm \mathrm{SD}=123.5 \pm 3.5$ days). Baseline values for fetal metabolic parameters were obtained during a period of 2 hours, in which fetal acid-base balance was analyzed every 15 minutes.

Asphyxia was induced after 3 to 5 days recovery from surgery, by gradual reduction of maternal uterine blood flow by stepwise inflation of the balloon occluder around the common internal iliac artery. To maintain the fetus in a stable hemodynamic condition, uterine blood flow was gradually reduced over a period of 90 to 120 minutes until fetal $\left[\mathrm{O}_{2}\right]$ a reached approximately $35 \%$ of the baseline value, during which period acidemia occurred. This latter asphyxial condition was maintained for 1 hour, referred to as severe asphyxia (time $=0$ to $60 \mathrm{~min})$. At time $=$ 
$60 \mathrm{~min}$ the occluder was released and recovery monitored. The experiment was ended when either the fetus had died or, in case of fetal survival, after 3 days. When still alive after 3 days a relaparotomy was performed under general anesthesia. The fetus was perfused in vivo with a fixative solution to perform histologic analysis of the brain (12).

\section{Calculations and data analysis}

Because CSF levels of lactate, nucleosides, and purine bases may be indicative for fetal survival after asphyxia, the 22 animals were divided into survivors and non-survivors. Survival was established if the fetus was still alive 12 hours after asphyxia.

In both groups mean baseline values (from time $=-240 \mathrm{~min}$ to tims $=-120$ $\mathrm{min}$ ) were determined, and compared with asphyxia values (from time $=0$ min to time $=60 \mathrm{~min}$ ) and with recovery values (from time $=60 \mathrm{~min}$ to time $=180 \mathrm{~min}$ ), using a Wilcoxon matched-pairs signed-ranks test.

Differences between survivors and non-survivors were tested with the two-tailed Mann-Whitney $U$ test. Within one animal differences between parameters obtained at surgery and during baseline were tested with a paired t-test. For all statistical tests a $p<0.05$ was accepted as level of statistical significance.

\section{Results}

Eleven of the 22 fetal lambs (50\%) survived longer than 12 hours after asphyxia. The limit of 12 hours was arbitrarily chosen. Since only one animal survived in the range from 6 to 20 hours, a change of this limit would not result in major shifts from one group to another. The mean (median) $\pm \mathrm{SD}$ surviving time was $62.2(72) \pm 22$ hours and $2.4(2) \pm 1.7$ hours, for the surviving and the nonsurviving group, respectively.

Figure 8.1 shows the time course of the metabolic condition of both groups. During occlusion mean $\left[\mathrm{O}_{2}\right]$ a decreased, leading to anaerobic fetal metabolism and acidemia with a mean $\mathrm{pH}$ of $7.02 \pm 0.03$ at time $=60 \mathrm{~min}$. This was associated with a decrease of $\mathrm{BE}$ to $-17.0 \pm 1.0 \mathrm{mM}$. After release of the occluder the $\left[\mathrm{O}_{2}\right]$ a steadily increased in surviving animals (open circles) leading to $\mathrm{pH}$ and $\mathrm{BE}$ values returning to baseline levels. This was in contrast with nonsurviving animals (filled circles): release of the occluder resulted only temporarily in an increased $\left[\mathrm{O}_{2}\right] \mathrm{a}$, whereas $\mathrm{pH}$ and $\mathrm{BE}$ did not return to baseline levels. No differences between both groups were demonstrated before and during asphyxia, whereas from time $=150$ min onwards $\left[\mathrm{O}_{2}\right] \mathrm{a}, \mathrm{pH}$ and $\mathrm{BE}$ values were higher in the surviving group compared with the non-surviving group ( $<<0.05$, two-tailed Mann-Whitney U test).

Table 8.1 summarizes the effect of surgery on CSF lactate, hypoxanthine, xanthine, and inosine levels. Mean concentrations of these parameters at surgery were compared with mean values 3 to 5 days later at baseline measurement. For 
hypoxanthine, xanthine, and inosine, CSF concentrations during surgery were significantly elevated compared to baseline values in the experiment, whereas CSF lactate levels were not elevated during surgery. Values of adenosine, guanosine, and uric acid are not shown in Table 8.1 since these concentrations were not elevated due to surgery.

Table 8.1. Effect of surgery on CSF lactate, hypoxanthine, xanchine, and inosine levels

\begin{tabular}{|l|c|c|c|c|}
\hline & Lactate & Hypoxanthine & Xinthine & Inosine \\
\hline Surgery & $2.59 \pm 0.31$ & $15.09 \pm 6.43$ & $5.85 \pm 1.86$ & $15.60 \pm 7.97$ \\
Baseline & $2.66 \pm 0.94$ & $9.80 \pm 2.83$ & $4.08 \pm 2.46^{*}$ & $3.53 \pm 2.611 / \%$ \\
\hline
\end{tabular}

Values are depicted as mean $\pm S D$, lactate in $m M$, hypoxanthine, xanthinc, and inosine in $! M$, $n=22$.

* p<0.01 (surgery versus baseline, paired $t$-test)

\#p<0.001 (surgery versus baseline, paired t-test)

Serum lactate levels were measured at four moments in the experiment, indicated with asterisks in Figure 8.1. Results are shown in Table 8.2. During asphyxia serum lactate levels increased 7 to 8 fold, and a slow decrease of serum lactate levels was observed during recovery. Differences between survivors and non-survivors did not reach significance.

Table 8.2. Serum lactate levels (mM)

\begin{tabular}{|l|c|c|c|c|}
\hline & Baseline & $\begin{array}{c}\text { Asphyxia } \\
\text { time }=60 \mathrm{~min}\end{array}$ & $\begin{array}{c}\text { Post-1 } \\
\text { time }=90 \mathrm{~min}\end{array}$ & $\begin{array}{c}\text { Post-2 } \\
\text { time }=180 \mathrm{~min}\end{array}$ \\
\hline Survivors & $1.33 \pm 0.46$ & $14.04 \pm 2.81$ & $13.27 \pm 2.47$ & $10.66 \pm 1.56$ \\
Non-survivors & $1.86 \pm 0.73$ & $13.24 \pm 5.21$ & $12.68 \pm 5.00$ & $11.80 \pm 6.08$ \\
\hline
\end{tabular}

Values are depicted as mean $\pm S D, n=11$ for both groups. No differences between groups.

Due to sampling difficulties withdrawal of CSF was not performed on standardized moments in the experiment. Besides the sample obtained during surgery, another $5 \mathrm{CSF}$ samples were considered the minimum in order to be sure that changes induced by asphyxia were adequately measured. Figure 8.2 shows all individual CSF levels of lactate, hypoxanthine, and xanthine from surviving animals (open circles, 11 animals, 73 samples, 5 to 10 samples per animal) and non-surviving animals (filled circles, 11 animals, 75 samples, 5 to 11 samples per animal).

In Figure 8.3, CSF levels of adenosine, inosine. guanosine, and uric acid are depicted for surviving animals (open circles. 11 animals, 73 samples, 5 to 10 samples per animal) and non-surviving animals (filled circles, 11 animals, 75 samples. 5 to 11 samples per animal). 


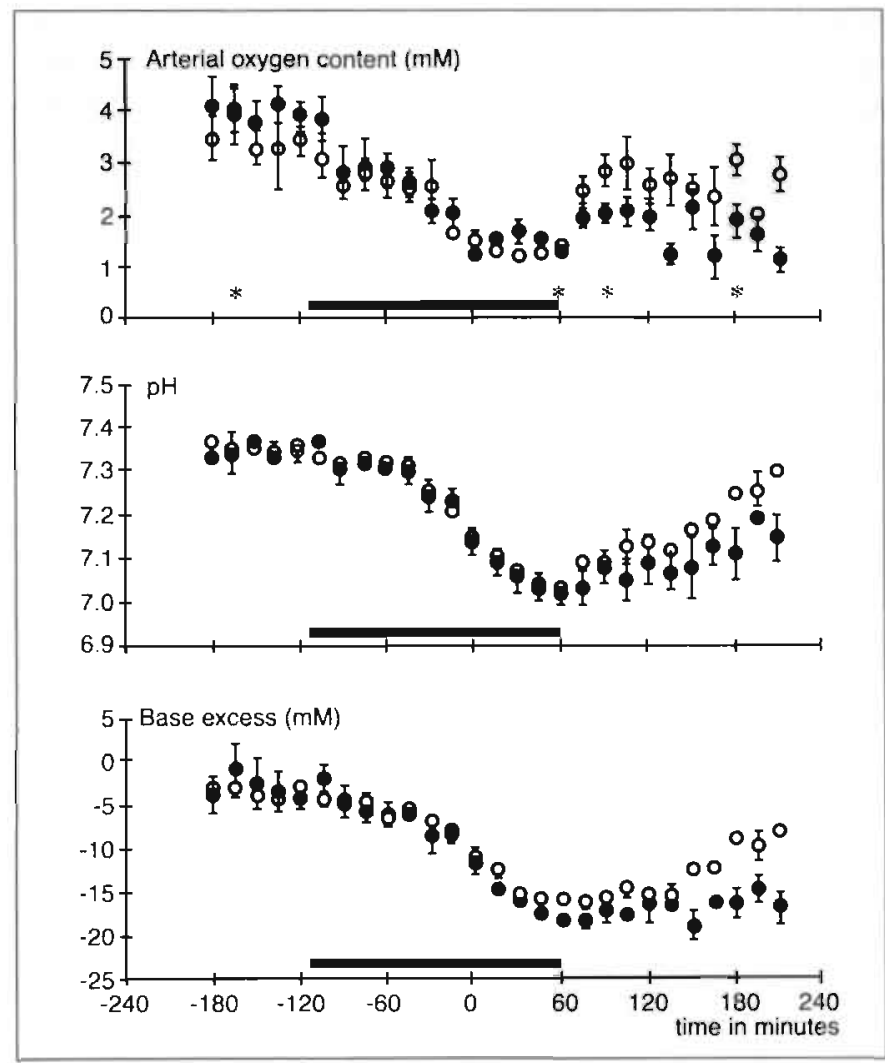

Figure 8.1. Time course of $\left[\mathrm{O}_{2}\right] \mathrm{a}(\mathrm{mM}), \mathrm{pH}$, and $\mathrm{BE}(\mathrm{mM})$. Values are means \pm SEM. Surviving animals $(n=11)$ are depicted as open circles, non-surviving animals $(n=11)$ as filled circles. Time -180 to $-120 \mathrm{~min}=$ baseline period; time -120 to $0 \mathrm{~min}=$ progressive reduction of uterine blood flow; time 0 to $60 \mathrm{~min}=1$ hour period of severe asphyxia; time 60 to $210 \mathrm{~min}=$ recovery period. Bar, period of occlusion. Asterisks in the upper panel represent serum lactate measurements.

Statistical analysis of the scattergrams of Figures 8.2 and 8.3 is complicated by the different number of samples per animal obtained at unequal time points. Therefore, mean values of individual animals were calculated in thebaseline period (from time $=-240 \mathrm{~min}$ to time $=-120 \mathrm{~min}$ ), in the period ofasphyxia (from time $=0 \mathrm{~min}$ to time $=60 \mathrm{~min}$ ), and in the recovery period (from time $=60 \mathrm{~min}$ to time $=180 \mathrm{~min}$ ). The means \pm SD of these values are presented for both surviving and non-surviving groups in Table 8.3. During asphyxia and especially during recovery levels were elevated compared with baseline values $(\mathrm{p}<0.05$ and $\mathrm{p}<0.01$, Wilcoxon matched-pairs signed-ranks test). During asphyxia the levels of hypoxanthine and lactate in CSF were higher in the non-surviving 
group compared with the surviving animals ( $<<0.01,2$-tailed Mann-Whitney Utest). During recovery the same levels were reached in both groups. The major difference between both groups was the rate of rise of ATP catabolites in CSF. In the non-surviving animals the levels during recovery were not significantly higher than concentrations during asphyxia, in contrast with the surviving fetuses: levels were elevated during asphyxia, but increased even further during recovery $(p<0.01$, Wilcoxon matched-pairs signed-ranks test).

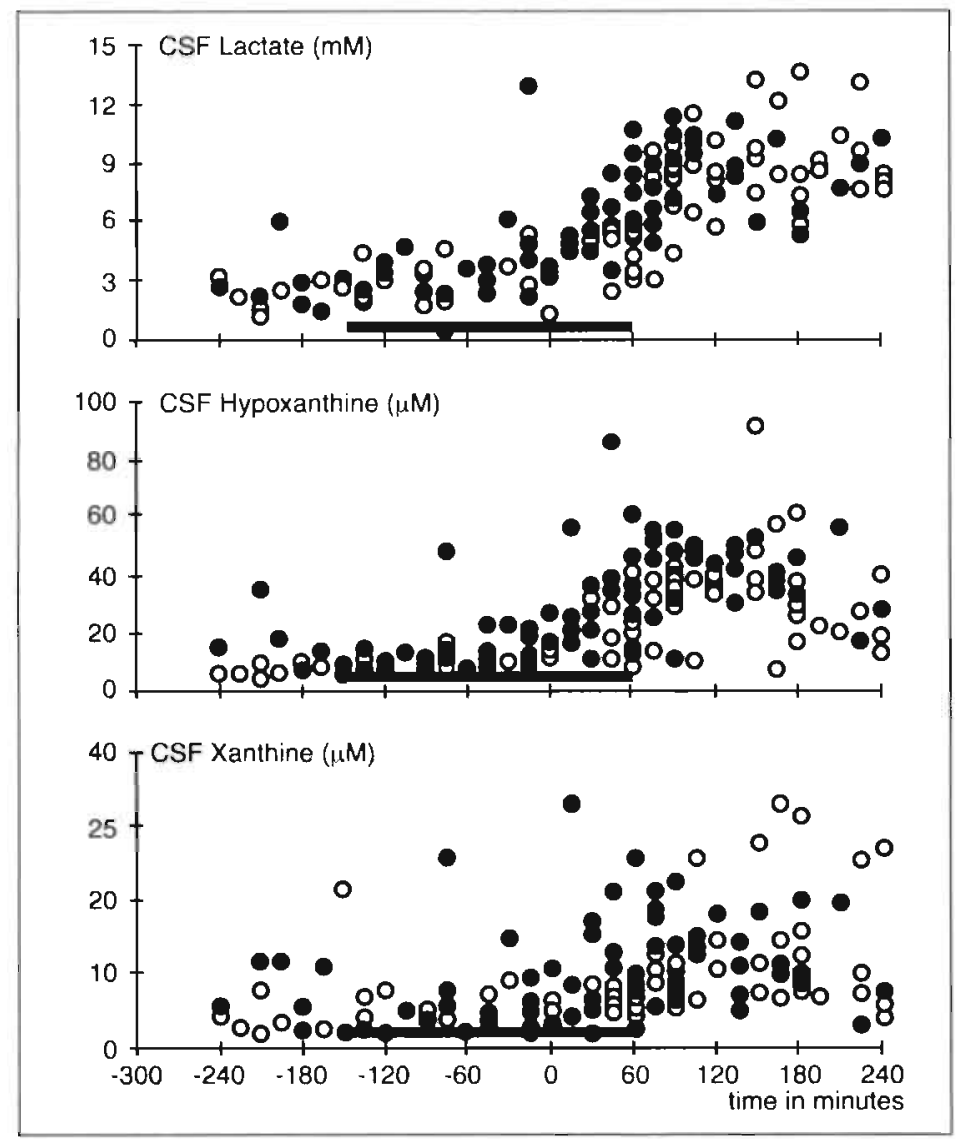

Figure 8.2. CSF levels of lactate (mM, upper panel), hypoxanthine $(\mu \mathrm{M}$, middle panel), and $x a n t h i n e(\mu \mathrm{M}$. lower panel). Time $(\mathrm{min})$ is depicted on the $\mathrm{X}$-axis. Time 0 to $60 \mathrm{~min}=$ 1 hour period of severe asphyxia. All individual values are shown; open circles represent surviving fetuses, filled circles represent non-surviving animals. Bar, period of occlusion 

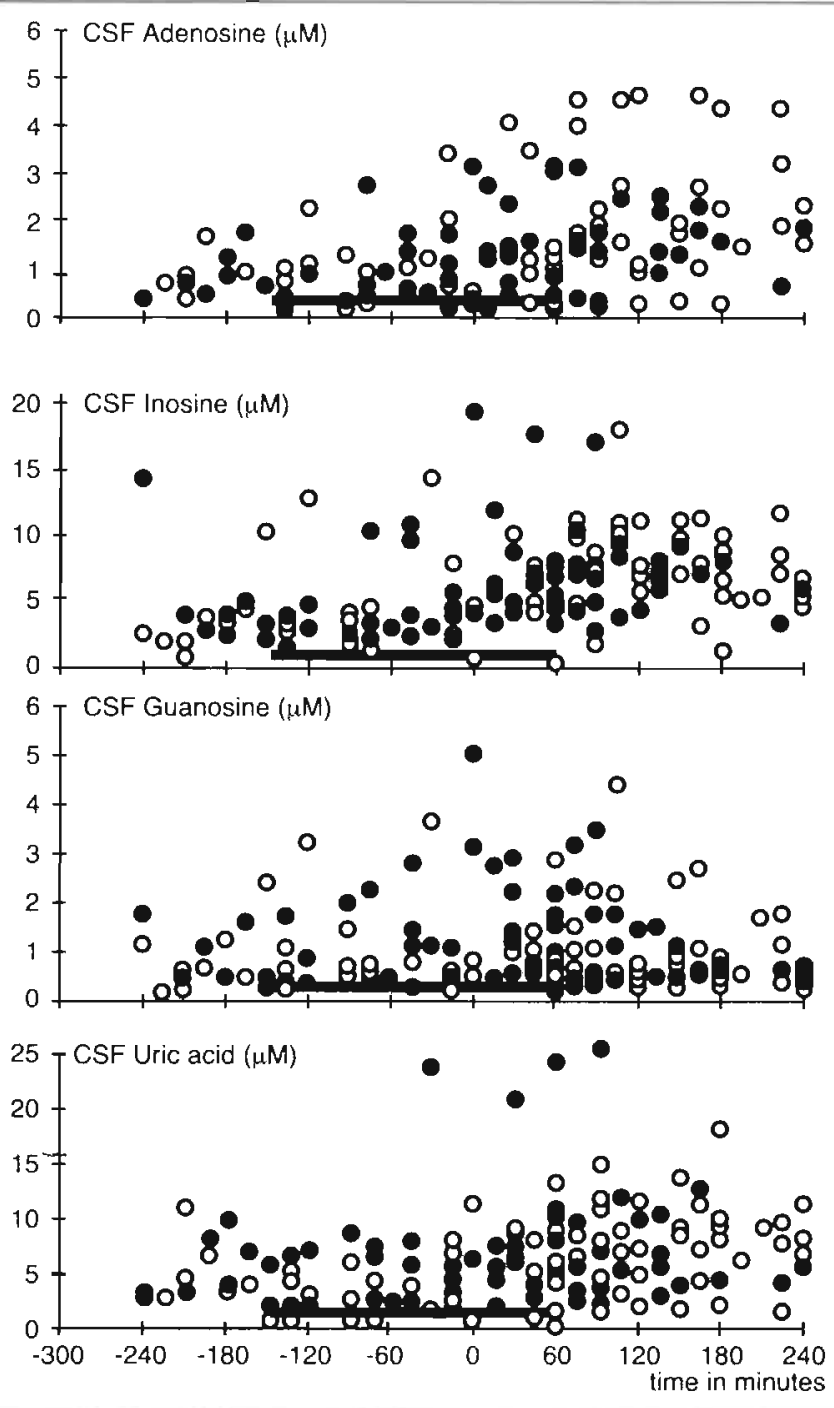

Figure 8.3. CSF levels of adenosine (first panel), inosine (second panel), guanosine (third panel), and uric acid (fourth panel). Values in $\mu \mathrm{M}$. Time (min) is depicted on the X-axis. Time 0 to $60 \mathrm{~min}=1$ hour period of severe asphyxia. All individual values are shown; open circles represent surviving fetuses, filled circles represent non-surviving animals. Bar, period of occlusion. 


\section{Discussion}

Purine nucleosides and bases (e.g., hypoxanthine, xanthine, inosine) are able to move freely between the inside and the outside of cells, whereas nucleotides (e.g., ATP, ADP, AMP) are larger and mainly confined in the cell interior. It is evident that extracellular levels of nucleosides and bases reflect thebreakdown of intracellular nucleotides, and are therefore indicative for cellular energy shortage or even for cellular damage (11). Because serum hypoxanthine levels during asphyxia mainly originate from fetal heart and liver (13), we decided to determine nucleoside concentrations in CSF, moreover since high levels of CSF hypoxanthine and xanthine after hypoxia have been associated with evidence of brain damage or subsequent death (14).

Table 8.1. stresses the importance of recovery after instrumentation. Complications during anesthesia can lead to oxygen shortage and ATP depletion, but in the present study CSF lactate levels were low, indicative for normal aerobic fetal metabolism. Surgery to expose the spinal cavity and the spinal tap were associated with cellular damage to such an extent that CSF hypoxanthine, xanthine, and especially inosine concentrations were significantly elevated compared with baseline levels 3 to 5 days after surgery. This trauma of instrumentation is in agreement with studies in rats in which placement of a subdural catheter resulted in transient elevation of neuron-specific enolase levels in CSF (15). Since levels of CSF lactate, hypoxanthine, and xanthine at time $=60$ min were higher than during surgery, the asphyxial event will have induced more cellular damage than the trauma of surgery.

\begin{tabular}{|c|c|c|c|c|c|c|}
\hline & \multicolumn{3}{|c|}{ SuTyivors } & \multicolumn{3}{|c|}{ Non-survivers } \\
\hline & Baseline & Asphyxia & Recovery & Baseline & Aspityoia & Recoveny \\
\hline Lactate & $2.61 \pm 0.94$ & $4.49 \pm 1.29$ @s & $8.70 \pm 2.029 \$$ & $3.04=1.14$ & $6.16 \mathrm{i}=1.24 @ \$$ & $923 \pm 1.83 * 9$ \\
\hline Hypoxanthine & $8.52 \pm 1.84$ & $20.0 \pm 7.80 . \$$ & $38.1=13.7 \mathrm{BSi}$ & $12.6=5.6$ & $33.3 \pm 10.967$ & $41.3 \pm 12.2^{\circ}$ \\
\hline Xanthine & $4.1 * \pm 2.37$ & $6.80 \pm 1.33^{~} \mathrm{~s}$ & $12.7 \pm 5.7 \mathrm{gS}$ & $5.06=3.18$ & $11.4 \pm 8.2$ & $13.6 \pm 6.2^{\circ}$ \\
\hline Adenosine & $0.85 \pm 0.38$ & $1.48=1.25 \$$ & $1.96 \pm 1.41 @ \$$ & $0.95 \neq 0.68$ & $1.36 \hat{i} \pm 0.92$ & $1.60=0.89$ \\
\hline inosine & $3.70=3.42$ & $5.63 \pm 2.59 \$$ & $8.10 \pm 2.55 ; \oplus \$$. & $3.33 \pm 1.17$ & $6.97 \neq 3.15^{\circ}$ & $8.20 \pm 3.72^{\circ}$ \\
\hline Guanosine & $0.80 \pm 0.78$ & $1.07 \pm 0.72 !^{\star}$ & $1.14=0.87^{*}$ & $0.86 \pm 0.63$ & $1.35 i \pm 1.11$ & $1.46 \pm 1.00$ \\
\hline Uric acid & $4.16=2.99$ & $6.16 \pm 3.72 \cdot \$$ & $8.61 \pm 4.16 @ \$$ & $5.70=2.38$ & $7.39 \pm 5.48$ & $0.08=7.13$ \\
\hline
\end{tabular}

Values are depicted as meart $\pm S D$, lactate in $\mathrm{mM}$, all other values in $\mu \mathrm{M}, \mathrm{n}=11$ for both groups. Baseline values are obtained during time $=-2.40$ to $-120 \mathrm{~min}$, asphyxia values from time $=0$ to 60 min, and recovery values from time $=60$ क $180 \mathrm{~min}$.

- $p<0.05$ (asphyxia or recovery versus baseline, Wilcoxon matched-pairs signed-ranks test)

(9) $p<0.01$ (asphyxia or recovery versus baseline, Wilcoxon matched-pairs signed-ranks test)

$\$ p<0.01$ (asphyxia versus recovery. Wilcoxon matched-pairs signed-ranks test)

2 $p<0.01$ (survivors versus non-5urvivors, 2-tailed Mann-Whitney U-test)

Oxygen shortage leads to catabolism of ATP, ADP, and AMP and to formation of adenosine. Adenosine is of great interest because it possesses strong biological activity, dependent on the 6 -amino group (11). Adenosine causes coronary vasodilation and protects the myocardium after hypoxia-ischemia $(9,16)$. 
Removal of the 6-amino group of adenosine to form inosine is a fast process. Levels of CSF inosine increase during asphyxia and reach maximum values during recovery (Table 8.3). These peak values however were lower than levels obtained immediately after surgery (Table 8.1 ). We hypothesize that the difference observed is explained by the time needed for metabolism. Due to the short interval between the spinal tap and storage of CSF in liquid nitrogen during the surgical procedure, the metabolism of inosine to hypoxanthine has not yet happened. During asphyxia however, the energy depletion has a more chronic character and inosine is metabolized to hypoxanthine.

Values of hypoxanthine, xanthine, and inosine obtained in the current study are comparable with human data from newborns after hypoxia (14). A microdialysis technique showed similar hypoxanthine and xanthine levels in the extracellular compartment of the brain of severely asphyxiated exteriorized fetal lambs. These results however were obtained in anesthetized lambs with their head fixed in a stereotactic frame (17). In the present study CSF hypoxanthine levels are shown to rise during asphyxia. This is in agreement with the net cerebral efflux of hypoxanthine measured in plasma during severe asphyxia in fetal lambs (18). Maximum CSF hypoxanthine and CSF xanthine levels were reached in the hours following occlusion. The time lag between nadir of asphyxia and peak hypoxanthine and xanthine levels may be caused by damage to the blood-brainCSF barrier after 1 hour of severe asphyxia, by delayed neuronal damage (19), or by methodological errors. Chances of the latter were small due to minimization of deadspace of the sampling catheter, careful handling of samples, use of the recommended HPLC to determine nucleoside levels (11), and presence of this time lag in the majority of animals. The elevated level of CSF hypoxanthine and xanthine during the recovery period, in which availability of oxygen was almost normal, is considered important because both bases act as substrate for the enzyme xanthine-oxidase in the production of oxygen derived free radicals $(4,5,11)$. Xanthine-oxidase is released during hypoxia from the fetal liver (4) and is present in the brain of fetal lambs (17). Indeed asphyxiated fetal lambs with the highest CSF hypoxanthine and xanthine levels had the most extensive histologic brain damage (12). In this respect the significant $(\mathrm{p}<0.01)$ higher levels of CSF hypoxanthine in non-surviving animals compared to surviving fetuses during asphyxia may be of importance, and may even predict fetal demise. In the presence of elevated levels of cerebral hypoxanthine and xanthine a large amount of oxygen administered during resuscitation after peripartal asphyxia may provide adverse effects. In newborn pigs resuscitation after asphyxia with $100 \%$ oxygen was not shown beneficially when compared with a group resuscitated with $21 \%$ oxygen (20). It may therefore be worthwhile to consider using $21 \%$ instead of $100 \%$ of oxygen during resuscitation after peripartal asphyxia.

CSF lactate levels also reached maximum values during the recovery phase. Concentrations were lower than serum lactate levels (Table 8.2), which is in 
agreement with the net influx of lactate into the fetal lamb brain during severe asphyxia and recovery (18). Serum lactate measured during asphyxia originates from a variety of organs as placenta, myocardium, and muscles, and used in the brain as an energy source both during hypoxia (21) and during reoxygenation (18). The rise of CSF lactate in the recovery period is of less importance than CSF hypoxanthine and xanthine levels since involvement of lactate in oxygen derived free radical production does not seem likely (5).

A remarkable difference between survivors and non-survivors is the rate of rise of ATP catabolites (and especially of hypoxanthine) in CSF. Whereas in the surviving group the levels at recovery were simjlar to the ones in non-survivors, the increment during asphyxia in non-survivors was twice the value in survivors. A similar tendency was observed for all parameters except guanosine. We have no clear explanation for this difference, nor why it is most pronounced for hypoxanthine. It could be argued that during asphyxia in the non-survivors ATP catabolism proceeds much faster, but why does the difference persist during recovery? A second possibility may be the ability of the survivors to salvage hypoxanthine more efficiently. Third, it should be kept in mind that changes in CSF reflect an equilibrium between many processes, including formation and release from a variety of cells, uptake and catabolism in scavenging cells and exchange with blood in the vasculature. Vascular efflux of ATP catabolites from CSF is guaranteed due to extensive fetal metabolism and placental diffusion. This implies that at a certain moment an equilibrium of maximal levels will be reached in CSF. This equilibrium may be reached during asphyxia in the non-surviving animals, in contrast to the surviving fetuses where maximal levels are reached during recovery. The difference observed could be due to the larger amount of cellular damage in those fetuses that will not survive the asphyxial insult. Which one of the theoretical explanations makes the difference between survivors and non-survivors cannot be decided from the present data. It may also be questioned whether the difference contributes to fetal demise.

In summary catheterization of the spinal cistern in preterm fetal lambs can be performed adequately and results in elevated CSF levels of inosine, hypoxanthine, and to a lesser extent xanthine. Experiments regarding CSF levels of nucleosides and purine bases should therefore preferably be performed in chronically instrumented animals. Three to 5 days after surgery fetal anaerobic metabolism was initiated, CSF levels of lactate, hypoxanthine, and xanthine, increased, whereas peak levels were reached in the recovery period. CSF hypoxanthine (and lactate) levels during asphyxia were higher in the non-surviving animals. The level of hypoxanthine may be related to oxygen derived free radical production, which aggravates brain damage. A second difference between both groups was the rate of rise of the ATP catabolites in CSF, which was higher in the non-surviving fetuses. Finally, CSF adenosine, guanosine, and uric acid seemed to increase in the survivors due to asphyxia, in contrast to the non-survivors. 


\section{References}

1. Peeters LLH, Sheldon RE, Jones MD, Makowski EL, Meschia G 1979 Blood flow to fetal organs as a function of arterial oxygen content. Am J Obstet Gynecol 135:637646

2. Rudolph AM 1985 Distribution and regulation of blood flow in the fetal and neonatal lamb. Circ Res 57:811-821

3. Younkin DP, Wagerle LC, Chance B, Maria J, Delivoria-Papadopoulos M 198731 PNMR studies of cerebral metabolic changes during graded hypoxia in newborn lambs. J Appl Physiol 62:1569-1574

4. Saugstad OD 1988 Hypoxanthine as an indicator of hypoxia: its role in health and disease through free radical production. Pediatr Res 23:143-150

5. McCord JM 1985 Oxygen-derived free radicals in post-ischemic tissue injury. $\mathrm{N}$ Engl J Med 312:159-163

6. Tanswell AK, Freeman BA 1984 Pulmonary antioxidant enzyme maturation in the fetal and neonatal rat. I. Developmental profiles. Pediatr Res 18:584-587

7. Rosenberg AA, Murdaugh E, White CE 1989 The role of oxygen free radicals in postasphyxia cerebral hypoperfusion in newborn lambs. Pediatr Res 26:215-219

8. Thordstein M, Bågenholm R, Thiringer K, Kjellmer I 1993 Scavengers of free oxygen radicals in combination with magnesium ameliorate perinatal hypoxic-ischemic brain damage in the rat. Pediatr Res 34:23-26

9. de Haan HH, de Haan J, Van Reempts JLH, Van Belle H, Hasaart THM 1993 The effect of adenosine transport inhibition on cardiovascular function and survival after severe asphyxia in fetal lambs. Pediatr Res 33:185-189

10. Bissonnette JM. Hohimer AR, Richardson BS 1981 Ventriculocisternal cerebrospinal perfusion in unanesthetized fetal lambs. J Appl Physiol 50:880-883

11. Harkness RA 1988 Hypoxanthine, xanthine and uridine in body fluids, indicators of ATP depletion. J Chromatography 429:255-278

12. de Haan HH, Van Reempts JLH, Vles JSH, de Haan J, Hasaart THM 1993 Effects of asphyxia on the fetal lamb brain. Am J Obstet Gynecol 169:1493-1501

13. Thiringer K, Karlsson K, Rosen KG, Kjellmer I 1984 Contribution of heart muscle, liver, skeletal muscle and placenta to the asphyxial hypoxanthine elevation in the acutely exteriorised fetal lamb. Biol Neonate 45:169-182

14. Harkness RA, Lund RJ 1983 Cerebrospinal fluid concentrations of hypoxanthine, $x$ anthine, uridine and inosine: high concentrations of the ATP metabolite. hypoxanthine, after hypoxia. J Clin Pathol 36:1-8

15. Hårdemark HG, Persson L, Bolander HG, Hillered L, Olsson Y, Påhlman S 1988 Neuron-specific enolase is a marker of cerebral ischemia and infarct size in rat cerebrospinal fluid. Stroke 19:1140*1144

16. Van Belle H 1993 Nucleoside transport inhibition: a therapeutic approach to cardioprotection via adenosine? Cardiovase Res 27:68-76

17. Kjellmer I, Andiné P, Hagberg H, Thiringer K 1989 Extracellular increase of hypoxanthine and xanthine in the cortex and basal ganglia of fetal lambs during hypoxia-ischemia. Brain Res 478: 241-247

18. Thiringer K, Blomstrand S, Hrbek A, Karlsson K, Kjellmer I 1982. Cerebral arteriovenous difference for hypoxanthine and lactate during graded asphyxia in the fetal lamb. Brain Res 239:107-117

19. Pulsinelli WA, Brierley JB, Plum JB 1982 Temporal profile of neuronal damage in a model of transient forebrain ischemia. Ann Neurol 11:491-498 
20. Rootwelt T, Loberg L, Moen A, Oyasæter S, Saugstad OD 1992 Hypoxemia and reoxygenation with $21 \%$ or $100 \%$ oxygen in newborn pigs: changes in blood pressure, base deficit, and hypoxanthine and brain morphology, Pediatr Res 32: 107-113

21. Mann LL 1970 Effect of hypoxia on fetal cephalic blood flow, cephalic metabolism and the electroencephalogram. Exp Neurol 29:336-348 


\section{Chapter 9}

Summary and conclusions 
The incidence of perinatal asphyxia depends on gestational age and definitions used, and varies around $2.0 \%$. Clinically, asphyxia refers to a condition following impaired gas exchange. Before it is concluded that cerebral damage results from perinatal asphyxia, both biochemical and clinical asphyxia should be present. All of the following criteria should therefore be at hand: (I) profound umbilical cord metabolic or mixed acidemia $(\mathrm{pH}<7.00$ in the umbilical artery), (II) persistence of an Apgar score 0 to 3 longer than 5 minutes, (III) neonatal neurologic sequelae, e.g., seizures, hypotonia, or coma, and (IV) multiorgan system dysfunction (cardiovascular, gastrointestinal, hematologic, pulmonary, or renal). Chapter 1 describes various methods for fetal surveillance and detection of asphyxia in the newborn. These techniques however increased medical intervention but failed to improve neonatal outcome. To develop beneficial therapeutical strategies, research should be directed upon basic understanding of factors playing a role in fetal asphyxia. The latter explains the objectives of the present study.

In chapter 2 the literature regarding fetal asphyxia is reviewed concentrating on heart and brain. Pathophysiology is discussed, fetal adjustments to asphyxia are explained, and the mechanisms by which oxygen shortage lead to fetal damage are summarized. Main issues are the role of oxygen derived free radicals, of calcium, and of excitatory neurotransmitters.

The present study is designed to evaluate effects of fetal asphyxia on cardiovascular parameters, on the ECG, on appearance of lactate and ATP degration products in cerebrospinal fluid, on recovery after asphyxia, and on histologic brain damage due to asphyxia. We used chronically instrumented fetal sheep, well known in perinatal research. This model offers the opportunity to investigate the fetus for a prolonged period, while still in utero. The sheep fetus is 3 to $5 \mathrm{~kg}$ in weight when born, allowing extensive instrumentation of fetuses without premature onset of labor or fetal demise. Surgery was performed in 47 fetal lambs. Mean gestational age was $120.0 \pm 2.8$ days, term is 147 days. Fetal instrumentation involved placement of catheters in axillary and femoral artery, femoral vein, spinal cisterne (to obtain CSF), trachea, and amniotic cavity. Electrodes were placed biparietally to measure the electrocorticogram, and on cardiac apex and both forelimbs to measure the ECG. Three to 5 days after surgery fetal asphyxia was induced by inflation of a balloon occluder around the maternal common internal iliac artery, which reduced uterine perfusion causing fetal oxygen shortage, the onset of anaerobic metabolism and acidemia. Reduction of uterine perfusion was performed gradually in a period of 60 to 90 minutes. until the fetal arterial oxygen content was approximately $35 \%$ of baseline level. At that moment mean fetal $\mathrm{pH}$ had decreased to 7.15. The arterial oxygen content was maintained at this level for 1 hour, during which the mean $\mathrm{pH}$ decreased to 7.03. After this period the occluder was released and recovery was monitored. Immediately after each step of increased occlusion fetal heart rate decreased and arterial blood 
pressure rised. Within a couple of minutes however fetal heart rate and arterial blood pressure normalized. During sustained asphyxia fetal tachycardia developed in combination with a normal blood pressure. Fetal blood flow (measured with radioactive microspheres) was redistributed toward myocardium and cerebrum. After release of the occluder the distribution of fetal blood normalized in the normoxemic surviving animals, in contrast with fetuses that remained hypoxemic and did not survive the asphyxial event.

The influx of calcium into neurons after oxygen shortage is considered of major importance during cell death. Calcium channel blocking agents (as, e.g., flunarizine) are shown to be neuroprotective in a variety of experiments when given before the period of oxygen shortage. Chapter 4 describes the effect of flunarizine treatment after fetal asphyxia. In the current study severity of asphyxia was considerable: only five of the 15 fetuses survived the asphyxia, four flunarizine-treated and one out of the control group. Influences of flunarizine on regional cerebral blood flow, fetal heart rate or arterial blood pressure could not be demonstrated. The latter is important since studies on calcium channel blockers have been reported where treatment of severely asphyxiated newborns resulted in dramatic hypotension leading to discontinuation of treatment.

Adenosine is formed during catabolization of ATP during energy shortage. Adenosine is considered to possess beneficial pharmacological activities after oxygen shortage, leading to vasodilation, reduced platelet and thrombocyte activation, and reduction of afterload. Furthermore, adenosine acts cardioprotective due to its antiadrenergic and antiarrhythmic properties. Since myocardial pump failure may contribute to the fetal demise observed after asphyxia, we pretreated $50 \%$ of a group of 14 fetal lambs with R-75231, an adenosine transport inhibitor (chapter 5). If transport of adenosine is inhibited, its catabolism is inhibited, and adenosine can perform beneficial activities for a prolonged period. Although myocardial blood flow itself did not differ between groups, the R-75231-treated animals had an enhanced increase of myocardial blood flow during asphyxia. Furthermore, treated animals recovered faster, and survived longer: all of the R-75231-treated animals recovered after asphyxia, whereas in the control group only three of the seven fetuses recovered and survived, the difference being significant. These results however were based on small numbers and levels of significance were only marginally reached. Since interanimal variation is large the experiments were repeated in a double blind randomized controlled trial. With this setup however, the beneficial effects of $\mathrm{R}$ 75231 could not be confirmed.

Delayed neuronal death is observed for several days after oxygen shortage. Furthermore, it can take up to 72 hours before neurons show histological features characteristic for asphyxial damage. Therefore, the time lag between asphyxia and fixation prior to histologic evaluation of brain damage should be at least 72 hours. This implicates that only those animals that survived longer than 72 
hours could be used for in vivo fixation (replacement of fetal blood by a fixative solution) and histologic evaluation. Microscopic analysis of eight cerebral areas demonstrated brain damage mainly confined to the Purkinje cells of the cerebellum (chapter 6). These cells are large and have a high level of metabolism: oxygen and energy shortage may lead to irreversible damage in these cells at first. Brain damage however was not extensive. There appeared to be a narrow border zone between intrauterine fetal death due to asphyxid. and survival without any histologic sign of brain damage. This may be due to the fact that after severe asphyxia primarily the myocardium denominates survival. The clinical situation is different. Birth of a severely asphyxiated infant which would have died due to myocardial failure leads to active resuscitation, cardiac support, and mechanical ventilation. Due to this therapy the infant may survive, thus widening the narrow border zone between death and survival without deficits after asphyxia. Neonates in this border zone are at greater risk for severe morbidity.

Myocardial dysfunction in adult cardiology leads to changes in the ECG. In the fetus therefore, asphyxia might also cause ECG changes due to anaerobic myocardial metabolism. In some studies fetal hypoxemia is indeed associated with changes in the T-top of the ECG expressed as an elevated T/QRS ratio, suggesting a possible use of the $T / Q R S$ ratio as a parameter in fetal surveillance. A CTG monitor is designed in which the CTG is combined with an on-line analysis of all T/QRS ratio. Clinical trials with this ST-analyzer are not unequivocal. Analysis of the T/QRS ratios from the 47 fetal lambs of the current study before, during and after asphyxia reveals that the T/QRS ratio is inappropriate to predict fetal oxygen shortage or fetal acidemia (chapter 7). The T/QRS ratio was not correlated properly with fetal serum lactate levels or survival either. The T/QRS ratio was not able to identify compromized fetuses that died in utero. Elevated myocardial blood flow may have resulted in an adequate oxygen supply to myocardial cells, without ST waveform changes. Based on the present research in fetal lambs therefore, its use in clinical practice as another method of fetal surveillance seems disputable.

During neuronal oxygen shortage anaerobic metabolism is initiated, ATP is degraded and ATP catabolites such as hypoxanthine and xanthine are released. Both substances are not only considered the result of cellular cerebral damage, but may also aggravate brain damage, since they act as substrates in the formation of oxygen derived free radicals during reoxygenation after asphyxia. We measured levels of CSF hypoxanthine and xanthine, purine bases and lactate during the experiment in 22 fetuses (chapter 8). Surgery itself increased CSF hypoxanthine, xanthine, and especially inosine levels. CSF levels of adenosine, guanosine or uric acid were not influenced by surgery.

During asphyxia levels of these ATP catabolites in CSF increased. Maximum levels were reached during the recovery period and were similar for surviving and non-surviving animals. During asphyxia however CSF levels of hypoxanthine and lactate were higher in the non-surviving fetuses. The rate of rise 
of ATP catabolites in CSF was higher in the non-surviving animals, and may therefore be predictive for fetal demise.

In summary, the fetal lambs had a tachycardia and a normal blood pressure after prolonged oxygen shortage, in combination with an increased cerebral and myocardial blood flow and a raised T/QRS ratio. These cardiovascular parameters were not predictive for recovery, nor were they influenced by R-75231 or flunarizine. The severity of asphyxia is indicated by the intrauterine mortality rate of $53 \%$. In surviving animals microscopic brain damage was mainly confined to the large cerebellar Purkinje cells, known to possess a high level of metabolism. Histologic brain damage however was not extensive. The present experiments confirm the narrow margin between lethality and survival without any damage after fetal asphyxia. This is in agreement with the absence of detectable neurologic sequelae in the majority of severely asphyxiated neonates. The brain sparing effect during oxygen shortage is attributable to a variety of factors, including increment of cerebral perfusion and reduction of cerebral metabolism. Accumulation of hypoxanthine and xanthine in the brain, known to act as substrate in the oxygen derived free radical production during reoxygenation after asphyxia, may have an adverse effect on final outcome. Indeed CSF hypoxanthine levels during asphyxia were elevated in non-surviving animals compared to surviving animals, and the rate of rise of the increment of ATP catabolites was higher in the non-surviving fetuses.

The current thesis summarizes the inadequate methods of fetal surveillance, discusses pathophysiology of fetal asphyxia, and denotes various mechanisms potentially leading to cerebral damage after asphyxia. Furthermore, in the fetal sheep severe asphyxia is studied, and several protective cardiac and cerebral aspects are discussed. Although intrauterine demise was considerable, the amount of histologic damage in the adequately preserved group was not extensive. It should however be kept in mind that abnormalities of function do not necessarily have to be microscopically detectable.

Fortunately, fetal asphyxia is not always fatal asphyxia. Future research is continued, and directed upon the immature brain, prior to myelination. Furthermore, an arterial blood pressure below the limit of autoregulation seems to be associated with cerebral damage. During hypotension the fetus will suffer from reduced cerebral perfusion, leading to diminished cerebral oxygen delivery. Another important observation concerns the role of growth factors in brain development. Experimentally induced lack of growth factors mimics secondary neuronal damage after asphyxia, which may offer possible therapeutic strategies in the first days after oxygen shortage.

We have to conclude that the brain is complex. But if cerebral processes occurring during asphyxia would be so simple that we could fully understand them, we would be so simple that we couldn't. 


\section{Hoofdstuk 9}

Samenvatting en conclusies 
Zuurstoftekort komt voor bij ongeveer 2,0\% van alle pasgeborenen, afhankelijk van de zwangerschapsduur en de gebruikte definitie. De combinatie van zuurstoftekort met de daarop volgende verzuring wordt asphyxie genoemd. Voordat er geconcludeerd kan worden dat een geconstateerde hersenbeschadiging het gevolg is van asphyxie rondom de geboorte, dient er zowel sprake te zijn van klinische asphyxie als van biochemische asphyxie. De volgende criteria dienen allen aanwezig te zijn om deze gevolgtrekking te mogen maken: $(I)$ ernstige verzuring $(\mathrm{pH}<7,00)$ in het slagaderlijke navelstrengbloed), (II) Apgar score van 0-3 gedurende minimaal 5 minuten, (III) neurologische afwijkingen bij de pasgeborene, zoals b.v. epileptische activiteit, hypotonie of coma, (IV) afwijkingen in andere orgaansystemen. Alhoewel diverse (in hoofdstuk l beschreven) technieken worden toegepast ter bewaking van de foetale conditie en opsporing van asphyxie in pasgeborenen is het aantal door zuurstoftekort beschadigde kinderen niet afgenomen. Het doel van deze studie is een beter inzicht te krijgen in de factoren die een rol spelen bij foetale asphyxie, om zo eventueel behandelingsmogelijkheden te kunnen ontwikkelen.

In hoofdstuk 2 wordt de literatuur over foetale asphyxie samengevat, waarbij met name de effecten op hart en hersenen beschreven worden. De pathophysiologie wordt bediscussieerd, foetale aanpassingsmogelijkheden worden besproken, en de mechanismen die leiden tot foetale beschadiging worden samengevat. Een belangrijke rol hierin is weggelegd vor vrije zuurstof radicalen. voor calcium, en voor exciterende neurotransmitters.

De eigen studie werd opgezet om de effecten te evalueren van foetaal zuurstoftekort op cardiovasculaire parameters, op het ECG, op het verschijnen van lactaat en ATP afbraakproducten in het hersenvocht (de liquor cerebrospinalis), op het herstel na een periode van asphyxie, en op de microscopische hersenschade veroorzaakt door de asphyxie. Voor de studie zijn. chronisch geïnstrumenteerde schapen gebruikt. Dit maakt bestudering van het foetale lam gedurende een langere tijd mogelijk, terwijl het zich nog in de baarmoeder bevindt. Het lam weegt bij de geboorte tussen de 3 en 5 kilo, zodat een groot aantal catheters en electrodes operatief aangebracht kan worden zonder dat vroegtijdige weeënactiviteit of foetale sterfie optreedt. Er werden 47 foetale lammeren geopereerd bij een gemiddelde zwangerschapsduur van 120,0 $\pm 2,8$ dagen (een lam is voldragen bij 147 dagen). Catheters werden geplaatst in foetale aderlijke en slagaderlijke bloedvaten, in de spinale ruimte (om liquor cerebrospinalis te verkrijgen), in de luchtpijp, en in de amnionholte. Vervolgens werden electrodes geplaatst ter registratie van electrische hersenschors activite it en rondom het hart t.b.v. de ECG registratie. Drie tot vijf dagen later werd foetale asphyxie geïnduceerd door een ballon te vullen waardoor de slagaderlijke toevoer naar de baarmoeder verminderd werd. Hierdoor ontstond foetaal zuurstofickort, trad een anaerobe foetale stofwisseling en verzuring op. De toevocr van moederlijk bloed naar de baarmoeder werd langzaam verminderd in cen periode 
van 60 tot 90 minuten, totdat het foetale zuurstofgehalte ongeveer $35 \%$ van normaal bedroeg. Gedurende deze tijd daalde de slagaderlijke foetale $\mathrm{pH}$ naar 7,15. Daarna werd dit zuurstofgehalte gedurende 1 uur op ongeveer 35\% van normaal gehouden. In dit uur daalde de slagaderlijke pH naar 7,03. Hierna werd de ballon geleegd en het foetale herstel geobserveerd. Direkt na elke stap van vulling van de ballon trad een daling van de foetale hartfrequentie op met een stijging van de foetale bloeddruk. Na langdurig zuurstoftekort ontstond echter een. stijging van de foetale hartfrequentie waarbij de bloeddruk constant bleef. Tijdens de asphyxie trad een verandering in foetale doorbloeding op (gemeten m.b.v. radioactieve microspheren), ten gunste van hart en hersenen. Na het leegmaken van de ballon normaliseerde de foetale doorbloeding van hart en hersenen in de dieren die de asphyxie overleefden.

De instroom van calcium in zenuwcellen na zuurstoftekort wordt beschouwd als een belangrijke stap in het proces van celdood. Van selectieve blockers van deze calcium instroom (zoals b.v. flunarizine) is dan ook hersenbeschermende werking aangetoond, indien het medicament vóoraf werd toegediend. Hoofdstuk 4 beschrijft het effect van behandeling met flunarizine ná foetale asphyxie. In de huidige studie werd een ernstige asphyxie veroorzaakt: slechts 5 van de 15 foetale lammeren overleefden de asphyxie, 4 flunarizine behandelde dieren en 1 controle dier. Flunarizine leek geen invloed te hebben op de regionale doorbloeding, op de foetale hartfrequentie of de bloeddruk. Dit laatste is van belang daar studies bekend zijn waar toediening van calcium kanaal blockers aan asphyctische neonaten gestaakt diende te worden i.v.m. ernstige bloeddruk dalingen.

Gedurende energietekort wordt ATP afgebroken en wordt adenosine gevormd. Aan adenosine worden een aantal beschermende eigenschappen toegeschreven na zuurstoftekort, zoals vaatverwijding, gereduceerde activatie van bloedplaatjes en witte bloedlichaampjes, en vermindering van belasting voor het hart. Tevens zou adenosine beschermend werken door zijn dempende en antiarrythmische eigenschappen. Daar hartfalen een bijdrage zou kunnen leveren aan de foetale sterfte na asphyxie, werd $50 \%$ van een groep van 14 foetale lammeren behandeld met $R-75231$, een adenosine-transport remmer (hoofdstuk 5). Indien het transport van adenosine geremd wordt, vindt eveneens remming van de afbraak plaats en kan adenosine de beschermende werking gedurende langere tijd uitoefenen. Alhoewel de hartdoorbloeding op zich niet verschilde tussen beide groepen, trad er tijdens de asphyxie in de met $R-75231$ behandelde dieren een sterkere toename van de hartdoorbloeding op dan in de onbehandelde dieren. Tevens herstelden de behandelde dieren sneller en overleefden ze significant langer: alle $R-75231$ behandelde dieren herstelden na de asphyxie, in tegenstelling tot slechts 3 van de 7 onbehandelde dieren. Daar deze resultaten gevonden werden bij een kleine groep dieren en marginale significantie bereikt werd, is de studie uitgebreid. In een studie met meer dieren en een dubbel blind 
gerandomiseerde opzet kon echter de beschermende werking van $R-75231$ niet bevestigd worden.

Gedurende een periode van enige dagen na het zuurstoftekort kan nog zenuwcel beschadiging optreden. Daarnaast kan het tot 72 uur duren voordat onherstelbaar beschadigde zenuwcellen als zodanig herkenbare vormen aannemen. Derhalve dient de periode tussen de asphyxie en de fixatie ten behoeve van microscopische beoordeling minimaal 72 uur te bedragen. Dit impliceert dat slechts de dieren die minimaal 72 uur overleefden gebruikt konden worden voor in vivo fixatie (het vervangen van foetaal bloed door een fixatief) en microscopische beoordeling. Microscopische analyse van een achttal hersengebieden toonde zenuwcel beschadiging aan die voornamelijk gelocaliseerd was in de Purkinje cellen van de kleine hersenen (hoofdstuk 6). Dit zijn grote cellen met een hoog stofwisselingsgehalte: tekort aan zuurstof en andere voedingsstoffen zou in deze cellen het eerst tot beschadiging aanleiding kunnen geven. De hersenschade was echter niet uitgebreid. Dit zou deels verklaarbaar kunnen zijn uit het feit dat tijdens asphyxie met name het hart de overleving bepaalt. Klinisch ligt de situatie enigszins anders. De geboorte van een asphyctisch kind leidt tot actieve reanimatie, ondersteuning van het hart en beademing. Door dit ingrijpen kan een kind overleven, en hiermee zal het smalle grensgebied tussen dood en restloos genezen wijder worden. Pasgeborenen uit dit grensgebied lopen een grotere kans op ernstige beschadiging.

Slecht functioneren van het hart leidt bij volwassenen tot ECG veranderingen. Foetale asphyxie zou door het anaeroob worden van de stofwisseling in het hart eveneens aanleiding kunnen geven tot ECG afwijkingen. Inderdaad zijn er een aantal studies bekend waarbij foetaal zuurstoftekort geassocieerd is met veranderingen in de T-top van het ECG, hetgcen wordt uitgedrukt als een gestegen T/QRS ratio. Theoretisch zou deze T/QRS ratio derhalve gebruikt kunnen worden als een parameter bij foetale bewaking. Een CTG monitor is ontwikkeld waarin het CTG gecombineerd wordt met de tegelijkertijd weergegeven T/QRS ratio. Klinische studies met deze zgn STanalyzer zijn niet eensluidend. Analyse van de T/QRS ratio's van de 47 foetale lammeren uit de huidige studie voor, tijdens, en na de asphyxie toonde aan dat de $T / Q R S$ ratio ongeschikt is om een laag zuurstofgehalte of verzuring van het foetale slagaderlijke bloed te voorspellen (hoofdstuk 7). De T/QRS ratio was evenmin goed gecorreleerd met foetaal serum lactaat gehalte of foetale overleving. Langzaam verergerende foetale verzuring zonder belangrijke veranderingen in hartfrequentie of bloeddruk kon niet gedetecteerd worden m.b.v. ST-analyse. De enorme toename in de doorbloeding van het hart gedurende asphyxie (tot $400 \%$ ) en het daarmee eveneens toegenomen zuurstofaanbod aan het foetale hart zou geresulteerd kunnen hebben in een adequaat zuurstofaanbod aan de hartspiercellen, waardoor ST veranderingen niet optreden. Derhalve kan op basis ran het huidige onderzoek in foetale lammeren geen goede grond worden 
gevonden de $T / Q R S$ ratio klinisch te gaan toepassen als nieuwe methode bij foetale bewaking.

Tijdens zuurstoftekort treedt anaerobe foetale stofwisseling op, wordt ATP verbruikt en komen ATP afbraakproducten als hypoxanthine en xanthine vrij. Hypoxanthine en xanthine worden niet alleen geacht het gevolg van cellulaire schade te zijn, maar tevens de oorzaak van nog meer schade, daar deze stoffen in de fase van weefselreoxygenatie aanleiding geven tot de vorming van vrije zuurstof radicalen. De concentraties hypoxanthine, xanthine, purine basen en lactaat werden in de liquor cerebrospinalis gemeten in 22 foetale lammeren (hoofdstuk 8). De operatie zelf verhoogde het gehalte hypoxanthine, xanthine en in het bijzonder inosine in de liquor cerebrospinalis. De concentraties adenosine, guanosine en urinezuur in de liquor werden niet beinvloed door de operatie. Tijdens de asphyxie namen de concentraties ATP afbraakproducten toe. Maximum concentraties werden in de herstelfase bereikt, en waren niet verschillend voor de overlevende en de niet-overlevende dieren. Tijdens de asphyxie echter waren de hypoxanthine en lactaat gehaltes in de niet-overlevende lammeren hoger dan in de dieren die wel overleefden. Bovendien was de snelheid waarmee de concentratie ATP afbraakproducten in de liquor cerebrospinalis toenam veel hoger in die dieren die uiteindelijk niet zouden overleven. De hogere concentratie hypoxanthine en de snelheid van toename van de ATP afbraakproducten tijdens asphyxie zou geassocieerd kunnen zijn met meer weefselbeschadiging en zou derhalve voorspellend kunnen zijn voor de foetale overleving.

Samenvattend hadden de foetale lammeren na langdurig zuurstoftekort een toegenomen hartfrequentie en een normale bloeddruk. Tevens was er sprake van een toegenomen doorbloeding van hart en hersenen. Deze parameters waren, evenals de T/QRS ratio, niet voorspellend v.w.b. foetaal herstel, en evenmin. werden ze beinvloed door $R-75231$ of flunarizine. De ernst van de asphyxie is goed weergegeven door de sterfie van $53 \%$. In de overlevende dieren was de microscopische hersenschade voornamelijk beperkt tot de Purkinje cellen; grote cellen met een hoog stofwisselingsniveau. Microscopische schade was echter niet overvloedig aanwezig. De huidige experimenten bevestigen het bestaan van een smalle marge tussen foetale sterfie en herstel zonder aanwijsbare microscopische schade. Dit is in overeenstemming met de afwezigheid van zenuwcelschade in de meerderheid van de ernstig asphyctisch geboren kinder'n. Het horsenspar'nd' effect tijdens zuurstoftekort is het gevolg van verschillende factoren, wauronder toegenomen cerebrale doorbloeding en vermindering van het hersenmutabolisme. Ophoping van hypoxanthine en xanthine in de liquor cerebrospinalis heeft wellicht een negatief effect op de uiteindelijke uitkomst door de vorming van vrije zuurstof radicalen in de periode van reoxygenatie. Dit is in overeenstemming met het feit dat tijdens asphyxie het hypoxanthine gehalte in de liquor cerebrospinalis het hoogst was in de lammeren die niet zouden overleven. Tevens was de snelheid waarmee de concentratie ATP afbraakproducten in de liquor toenam hoger in de 
dieren die uiteindelijk niet zouden overleven.

Dit proefschrift bespreekt de inadequate foetale bewakingsmethoden, bediscussieert de pathophysiologie van foetale asphyxie en gaat in op de verschillende mechanismen die potentieel tot hersenschade na asphyxie kunnen leiden. Verder wordt in het chronisch geinstrumenteerde foetale schapemodel ernstige foetale asphyxie bestudeerd, en worden verschillende beschermende mechanismen bediscussieerd v.w.b. hart en hersenen. Alhoewel er een aanzienlijke sterfte optrad in de baarmoeder bleek er in de herstelde dieren niet veel microscopische hersenschade aanwezig. Een afwijkende hersenfunctie hoeft echter niet altijd microscopisch detecteerbaar te zijn.

Gelukkig is foetale asphyxie niet altijd fatale asphyxie. Het onderzoek wordt voortgezet, toegespitst op de onrijpe hersenen. Tevens lijkt een slagaderlijke bloeddruk onder het autoregulatieniveau geassocieerd te zijn met hersenschade. Gedurende die lage bloeddruk zal bij de foetus een verminderde hersendoorbloeding bestaan, hetgeen leidt tot een verlaagd zuurstof aanbod. Een andere belangrijke observatie houdt verband met de rol van groeifactoren bij hersenontwikkeling. Experimenteel opgewekt tekort aan groeifactoren heeft vele overeenkomsten met secundaire zenuwcelbeschadiging na zuurstoftekort. Dit biedt wellicht mogelijkheden tot behandeling in de eerste dagen na asphyxie.

De hersenen vormen een complex geheel. Als echter de cerebrale processen eenvoudig te begrijpen zouden zijn, zouden wij zo eenvoudig zijn dat we ze niet konden begrijpen. 


\section{Publications}




\section{Publications}

In the course of the studies, presented in part in this thesis, the following publications were elaborated:

\section{Papers}

I. de Haan HH, Van Reempts JLH, Borgers M, de Haan J, Vles JSH, Hasaart THM 1993 Possible neuroprotective properties of flunarizine infused after asphyxia in fetal lambs are not explained by effects on cerebral blood flow or systemic blood pressure. Pediatr Res 34:379-384

2. de Haan HH, de Haan J, Van Reempts $\mathrm{LLH}$, Van Belle H, Hasaart THM 1993 The effect of adenosine transport inhibition on cardiovascular function and survival after severe asphyxia in fetal lambs. Pediatr Res 33:185-189

3. de Haan HH, Van Reempts JLH, Vles JSH, de Haan J, Hasaart THM 1993 Effects of asphyxia on the fetal lamb brain. Am J Obstet Gynecol 169:1493-1501

4. de Haan HH, IJzermans ACM, de Haan J, Hasaart THM 1994 The T/QRS ratio of the electrocardiogram does not reliably reflect well-being in fetal lambs. Am J Obstet Gynecol, in press

5. de Haan HH, IJzermans ACM, de Haan J, Van Belle H, Hasaart THM 1994 Effects of surgery and asphyxia on levels of nucleosides, purine bases, and lactate in cerebrospinal fluid of fetal lambs. Pediatr Res, in press

\section{Scientific abstracts}

1. de Hain HH, Van Reempts JLH, Borgers M, de Haan J, Hasaart THM. Flunarizine does not affect regional cerebral blood flow in severely asphyxiated fetal lambs. Abstract no. 62, presented at the 38th annual meeting of the Society for Gynecologic Investigation, San Antonio, Texas, USA, march 1991

2. de Haan HH, de Haan J, Hasaart THM. Inhibition of adenosine transport may improve fetal survival in severely asphyxiated fetal lambs. Abstract no. 4, presented at the 18th annual meeting of the Society for the Study of Fetal Physiology, De Eemhof, the Netherlands, may 1991

3. de Haan HH, Wijffels MCEF. Hasaart THM. Adenosine transport inhibition does not alter the changes in ST waveform of the fetal lamb electrocardiogram during severe asphyxia. Abstract no. 17, presented at the SEOHS, Groningen, the Netherlands, november 1991. Winning abstract for the Collegium Chirurgicum Neerlandicum Award 1991 
4. de Haan HH, Van Reempts JLH, Borgers M. Van Belle H, de Haan J, Hasaart THM. Severe asphyxia in preterm fetal lambs does not result in extensive histologic brain damage. Abstract no. 104, presented at the 39th annual meeting of the Society for Gynecologic Investigation, San Antonio, Texas, USA, march 1992

5. de Haan HH, Wijffels MCEF, de Haan J, Hasaart THM. Adenosine transport inhibition and cardiovascular effects in asphyxiated fetal lambs. Abstract no. 554, presented at the 39th annual meeting of the Society for Gynecologic Investigation, San Antonio, Texas, USA, march 1992

6. de Haan HH, Van Belle $\mathrm{H}$, de Haan J, Hasaart THM. The increase in cerebrospinal fluid (CSF) hypoxanthine concentration after severe asphyxia in fetal lambs. Abstract no. El, presented at the 19 th annual meeting of the Society for the Study of Fetal Physiology, Niagara-on-the-Lake, Ontario, Canada, august 1992

7. de Haan HH, Van Reempts JLH, Borgers M, de Haan J, Hasaart THM. Histological brain damage and electrocortical changes after severe asphyxia in fetal lambs. Abstract no. D6, presented at the 19th annual meeting of the Society for the Study of Fetal Physiology, Niagara-on-the-Lake, Ontario, Canada, august 1992

8. de Haan HH, de Haan J, Van Belle H, Hasaart THM. Release of hypoxanthine in cerebrospinal fluid (CSF) during severe asphyxia in fetal lambs. Dutch Physiological Society, Young Physiologists Meeting, Amsterdam, october 1992. Pflügers Arch 1992;421:R38

9. de Haan $\mathrm{HH}$, de Haan J, Van Belle H, Hasaart THM. The elevated level of nucleosides in CSF after asphyxia may facilitate oxygen free radical formation and brain damage. Abstract no. P169, presented at the 40th annual meeting of the Society for Gynecologic Investigation, Toronto, Canada, march-april 1993 


\section{Curriculum vitae}

28 juli 1963 Geboren te Drachten (Frl)

1969-1975 Lagere school te Drachten (Frl), Huizen (NH), en Willemstad, Curaçao (NA)

1975-1981 Atheneum, P.C.S.G. Doetinchem (Gld)

1981-1989 Studie Geneeskunde, Rijks Universiteit te Groningen

1986 Doctoraal examen

1986-1987 Werkzaam in het Holy Family Hospital, Berekum, Ghana

1987-1988 Co-schappen op Curaçao, Bonaire en Saba (NA)

1989 Aanvullend co-schap Obstetrie en Gynaecologie, Academisch Ziekenhuis Maastricht

1989

Artsexamen, Cum Laude, Rijks Universiteit te Groningen

1989-1991 Assistent Geneeskundige Niet in Opleiding, afdeling Obstetrie en Gynaecologie, Academisch Ziekenhuis Maastricht

1991 Collegium Chirurgicum Neerlandicum Prijs 1991

1992-heden Assistent Geneeskundige in Opleiding, afdeling Obstetric en Gynaecologie, Academisch Ziekenhuis Maastricht Opleider: Prof. Dr. J. de Haan

1995-1996 Onderzoeksjaar Onderzoekscentrum voor Ontwikkelingsgeneeskunde \& Biologic, Universiteit van Auckland, Nieuw Zeeland Begeleider: Prof. Dr. P.D. Gluckman 
The publication of this thesis was financially supported by:

- Accountantskantoor H. de Haan

- Hoechst Holland N.V.

- Janssen Research Foundation

- Organon Nederland B.V.

- Pfizer B.V.

- Pie Medical Benelux B.V.

- Sanofi Winthrop

- Schering Nederland B.V.

- Serono

- Syntex B.V.

- Wyeth B.V. 


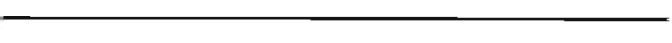


ISBN 90-9007452-X 